\title{
حق الطفل في الاستماع إليه في الخصومة المدنية \\ دراسة في القانون الفرنسي والقانون المصري على ضوء اتفاقية حقوق الطفل
}

\author{
دكثور \\ عثمان محمد عبد الثقادر \\ مدرس قانسون المرافعـات \\ كلية الحقوق- جامعة أسيوط
}





\section{مقدمة}

تحيط معظم التشريعات في مختلف الدول الطفل بسياج قانوني يتم من خلاله

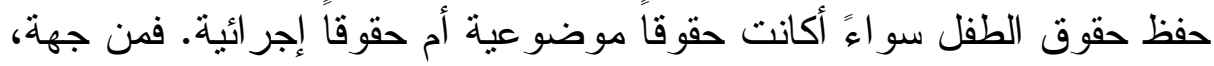

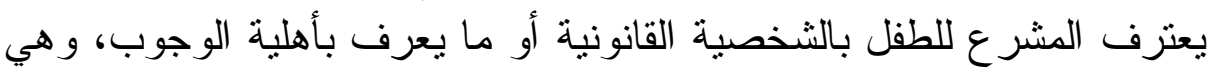

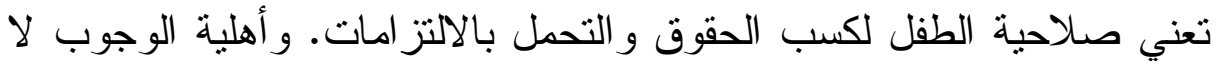
تثير أية مشكلة، باعتبار أن الطفل يتمتع بالشخصية القانونية منلكه منل الإنسان

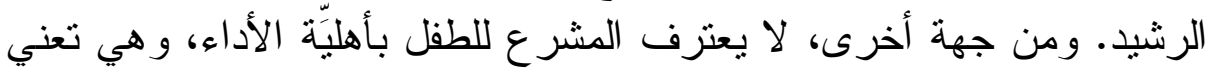

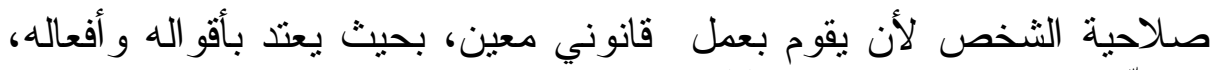

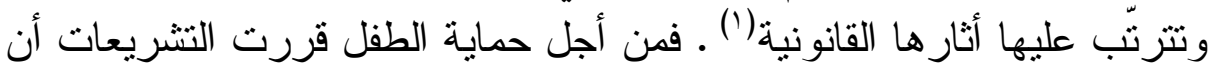

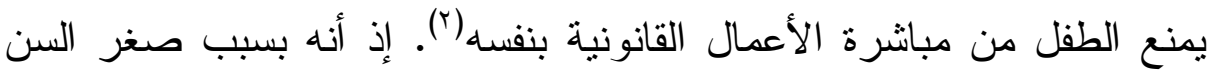

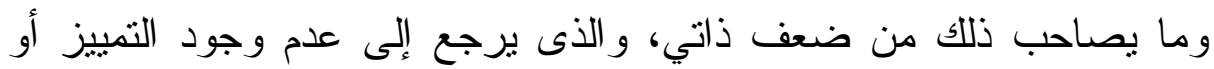

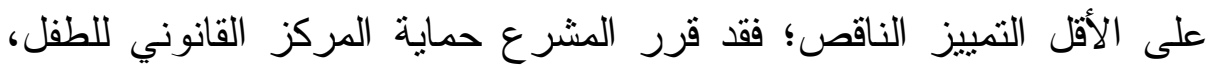

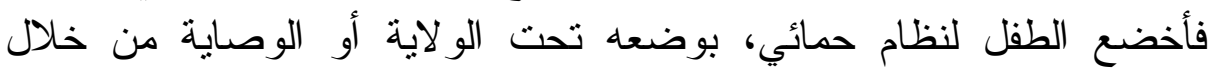

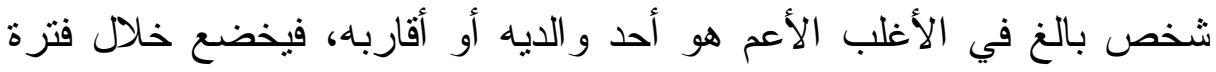
الطفولة لهذه الولاية أو الوصاية بحسب الأحوال. وبذلك تثبت للتبه للطفل أهلية

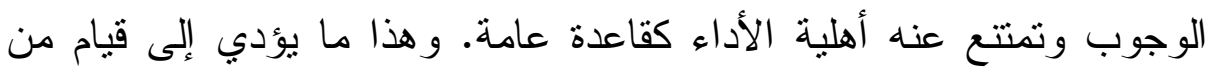
يمنل الطفل أو القاصر بتمثيله و اتخاذ القرار ات المتعلقة به، دون أن يكون لهذاء أداء

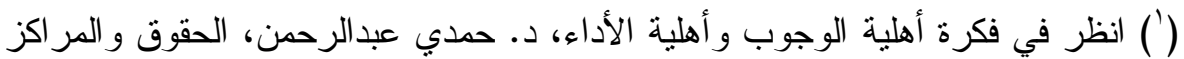

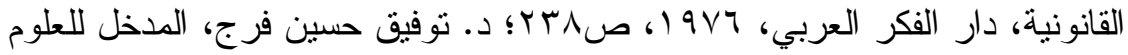

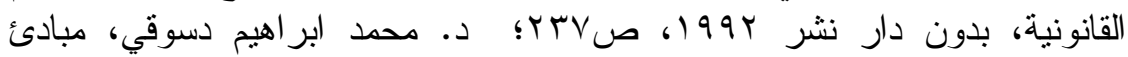

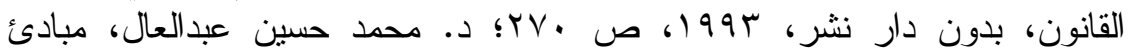

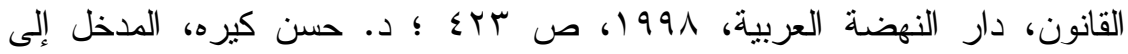

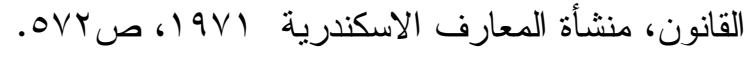
وفى الفقه الفرنسي:

G.Hubrecht, Droit civil, Edition Dalloz,1993, P.60., H.Roland et L.Boyer, Introduction au droit, Litec, 2004, n 1015, p.410., G. Cornu, L'âge civil : mélanges en l'honneur de P. Roubier, Droit privé, propriété industrielle, littéraire et artistique, Paris : Dalloz, Sirey 1961, p. 15

$\left({ }^{2}\right)$ C. Demolombe, Cours de droit civil, t. 1, Traité de la publication des effets et de l'application des lois en général : A. Dunand, L. Hachette, Paris, 4e éd. 1869, n 132, p.75. 


$$
\text { القاصر أي دور في ذلك. }
$$

و هذا ما ينطبق -أيضا- في قانون الإجر اءات المدنية. فمن ناحية قد

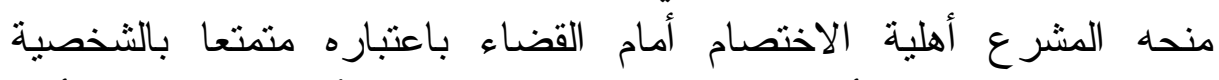

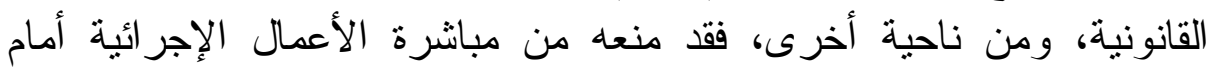

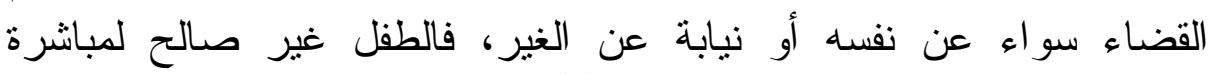

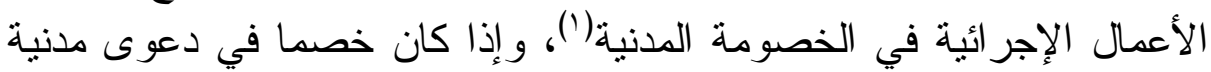

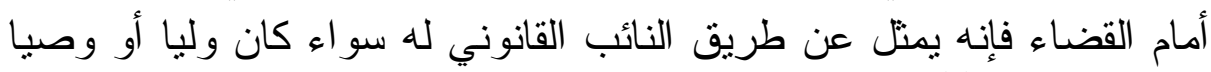

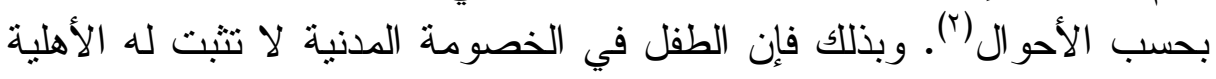

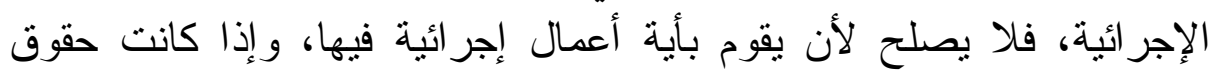
الطفل الموضوعية محلا للمنازعة فإن نائبه القانوني بحل بله محله في مباشترة الخصومة؛ فيلتزم بالتز اماته الإجر ائية ويكتسب حقو فائه المانه الاجر ائية.

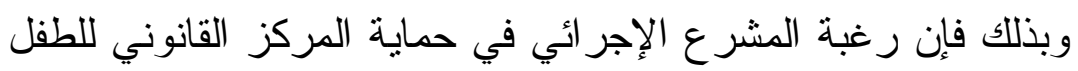

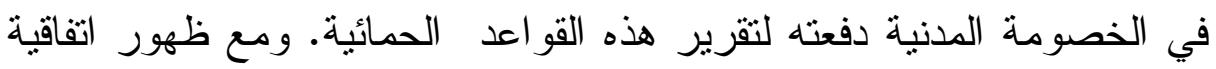

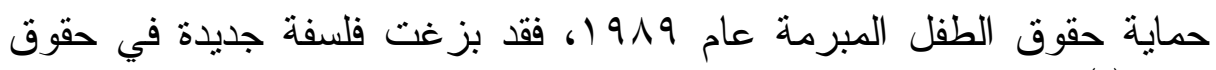

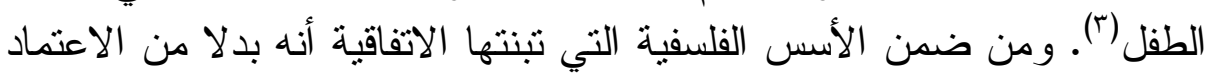

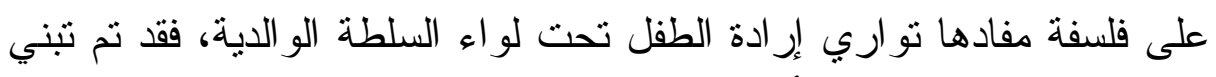

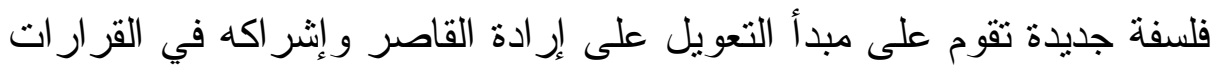

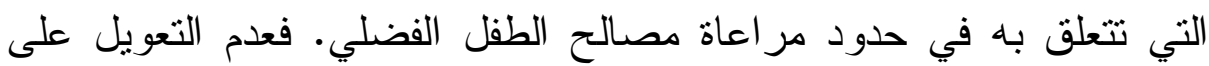

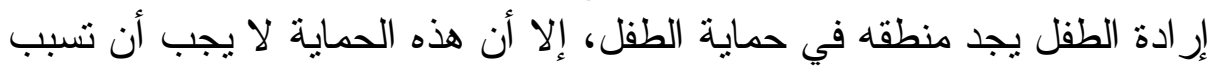

( ${ }^{1}$ S.Guinchard et C.Chaines et F.Ferrand, Procedure civile, 30 edition Dalloz, 2010,n 261, p.238, J.Vincent, Procedure civile, Dix-neuvieme edition, n 369, p.472.

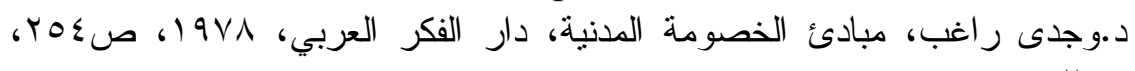

(2) M.-J. Gébler, Regards éthiques sur les droits de l'enfant : La parole de l'enfant en justice : D. 1989, . p. 118.

(3) O. Matocq et T. Dupré, La parole de l'enfant en justice après la Convention de New York, in Mélanges D. Huet-Weiller : LGDJ 1994, p. 309, C. Meininger Bothorel, Les apports de la Convention internationale des droits de l'enfant : Gaz. Pal. 18/20 nov. 2007 , p. 4. 


\section{له أضر ار ا، وتحرمه في كافة الأحو ال من التعبير عن إر ادته(').}

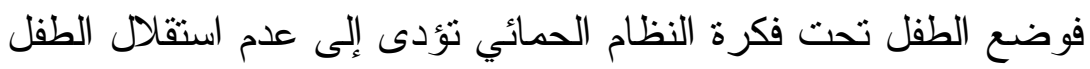

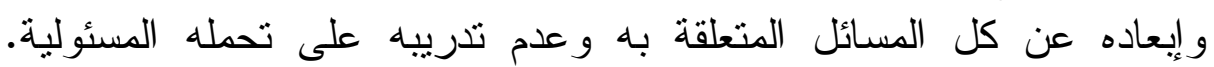

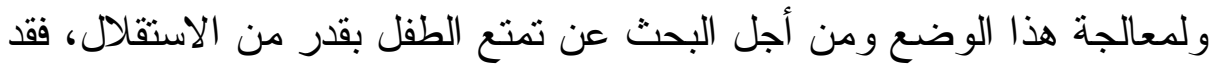

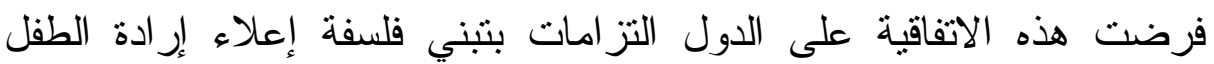

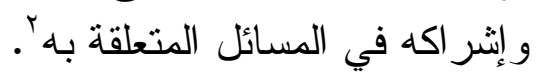

هذه الفلسفة لا تقوم على الاعتر اف للطفل بأهلية قانونية بشأن

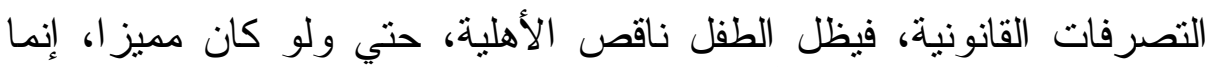

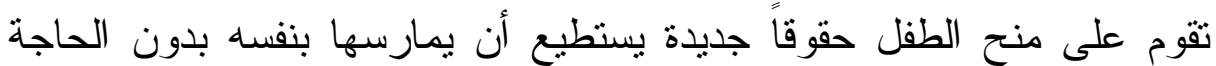
لنائب قانوني يقوم بها. و على رأس هذه الحقوق حقه في في الشتر اكه في الأمور

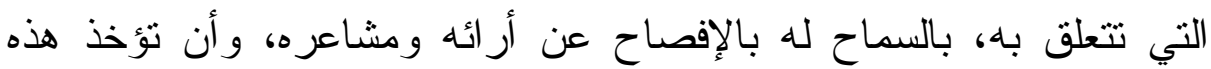

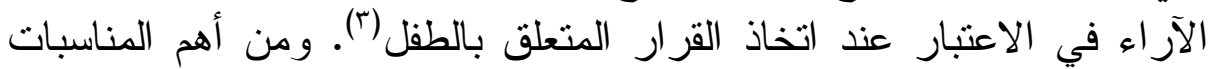

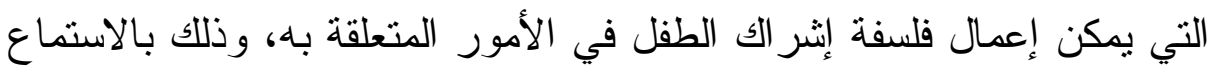

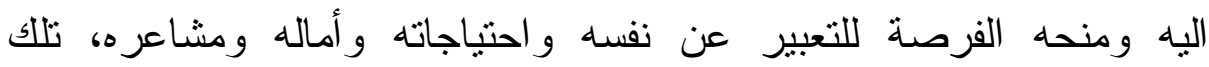

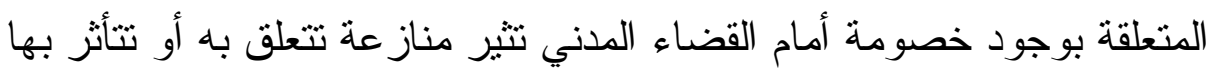
مصالحه دون أن يكون مدعى أو مدعى عليه في هذه الخصومة.

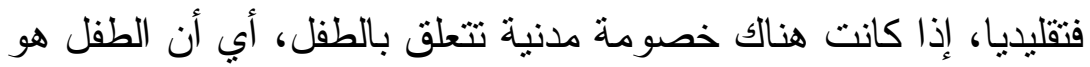

(1) M.PH. Gil-Rosado, Les libertés de l'esprit de l'enfant dans les rapports familiaux, éd. Défrenois, Paris, 2006, p. 5., G. Raymond, la Convention des Nations-Unies sur les droits de l'enfant et le droit français de l'enfance : JCP G 1990, I, 3451., D. Pical, Quelques aspects de l'évolution récente du droit de la famille : Gaz. Pal. 1994, 1, doctr. p. 658

(2) C.Watine - Drouin, Minorité, audition du mineur en justice, Défense de ses interest, Fasc.unique, Jur. Clas. civil code, art. 388.1 et 388.2 , 2009, no 2,p.3.

(3) A. Gouttenoire, Le statut de l'enfant depuis la convention internationale relative aux droits de l'enfant, Rev. Lamy Droit Civil, 2005, p.18, B. Kan-Balivet, Audition du mineur en justice,Fasc.10 JurisClasseur Encyclopédie des Huissiers de Justice, 2013, n 1., p.2. 
محل النزاع أو تتأثز مصالحه بالحل النهائي للنز اع، فإن الخصومة تكون بين

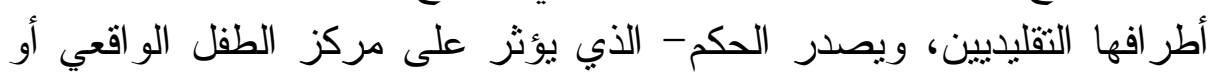

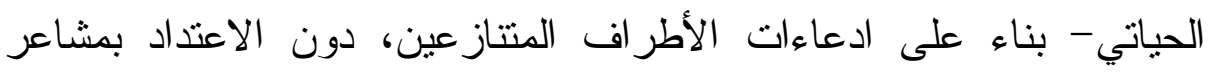

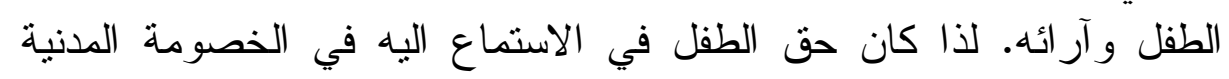

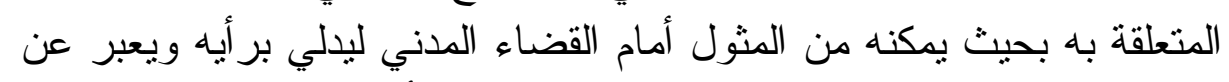

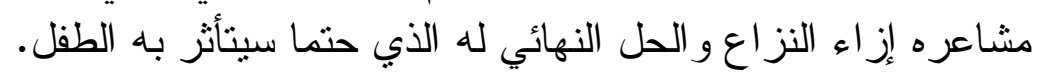

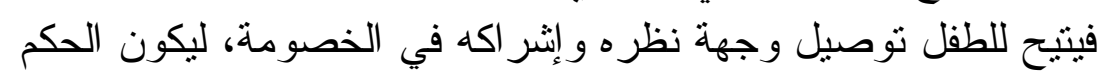

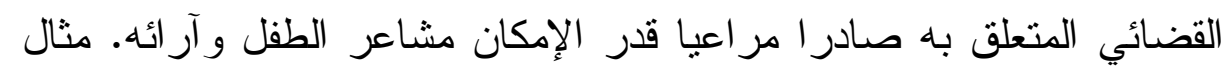

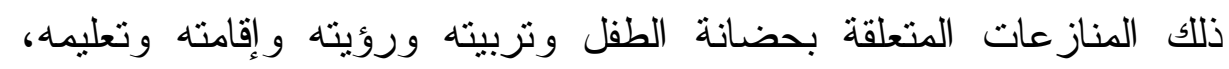

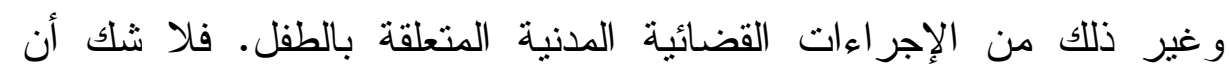

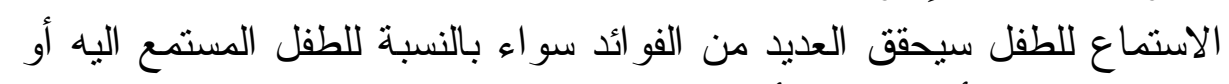

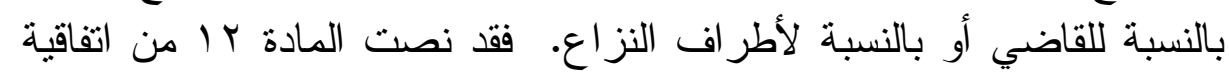

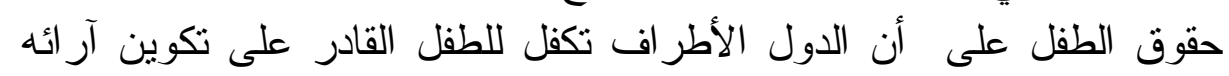

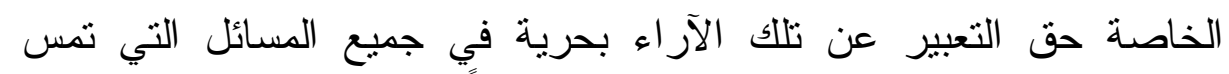

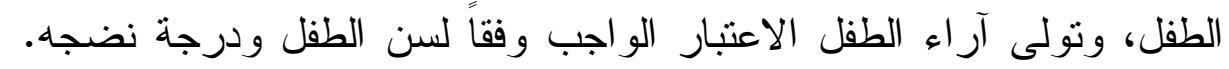

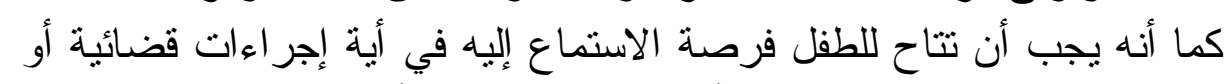

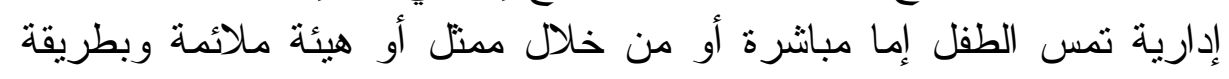
تتفق و القو اعد الإجر ائية للقانون الوطني.

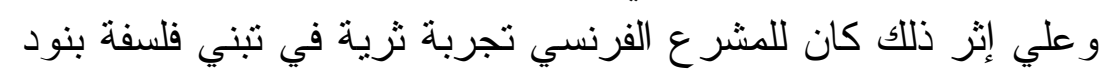

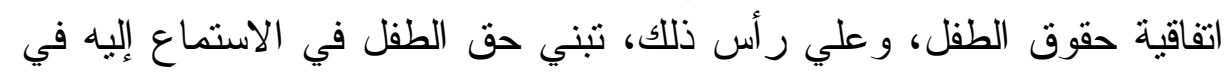

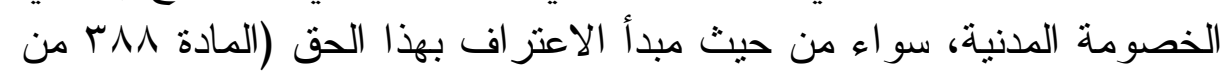

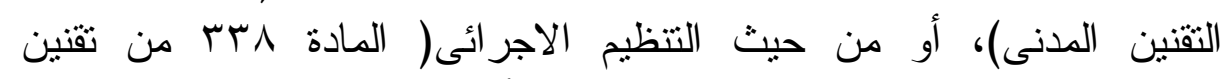

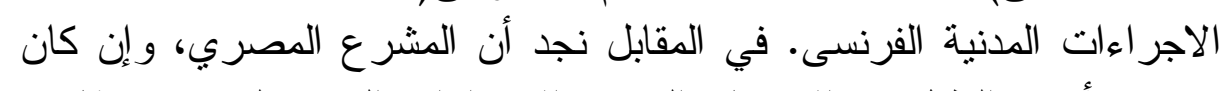

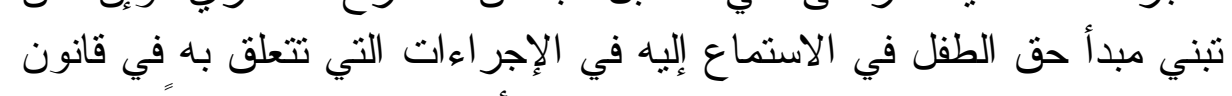

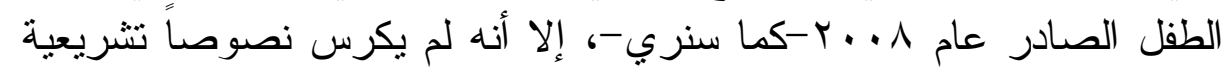

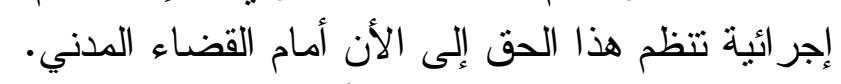

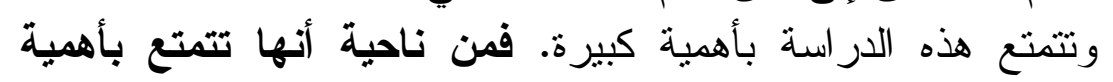

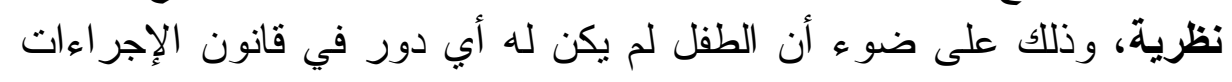

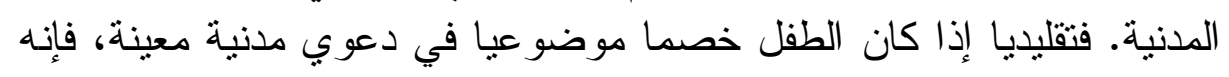

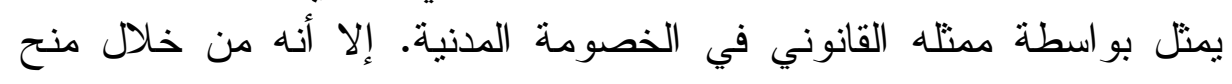


الطفل الحق في الاستماع إليه في الإجر اءات المتعلقة به، فقد ظهر للطفل دورٍ إجرائي جديد لم يكن لله من قبل. فمن خلال اليه فذا الإن الحق يصبح للطفل مجالاً

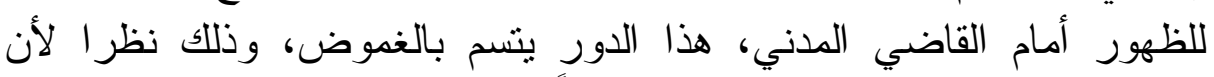

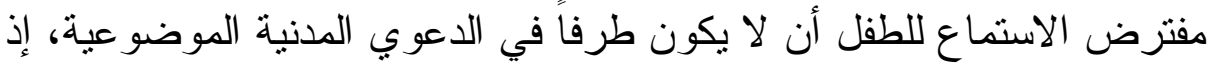

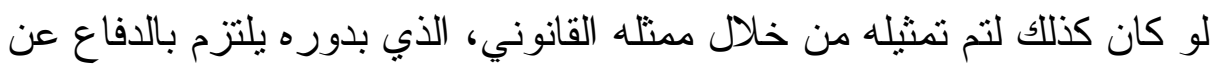
حقوق الطفل الموضوعية. ومن هنا تظهر الحاجة لتوضيح ملامح هذا المركز

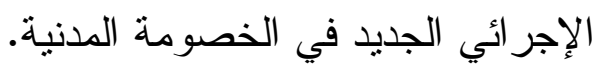

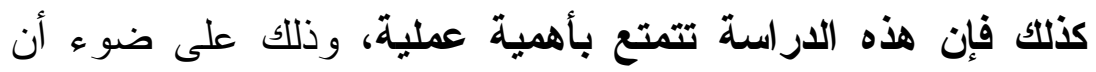

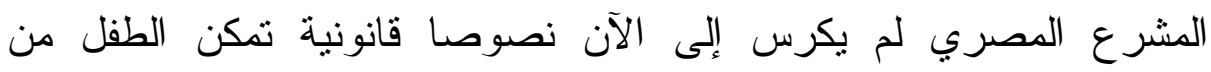

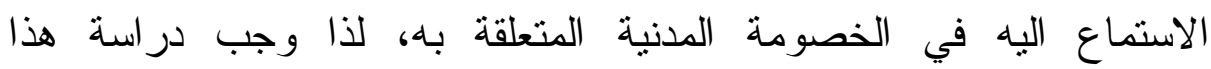
الموضوع في القانون الفرنسي، وذللك للتوصل إلى نموذج قانوني يمكن تبنيه

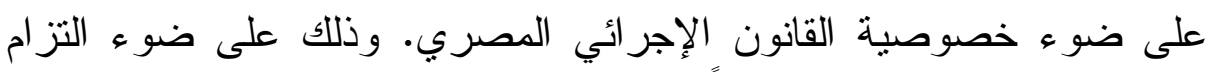
المشرع بتظيم هذا الحق أعمالاً لبنود اتفاقية حقوق الطفل التي التي انضدت اليها

$$
\text { جمهورية مصر العربية. }
$$

وسنعالج هذا الموضو ع من خلال خطة البحث التالية:

الفصل الأول: التكريس القاتوني لحق الطقل في الاستماع إليه في الخصومة خلة الئة المدنية الكرين.

المبحث الأول: مركز الطقل في الخصومة المدنية بصفة عامة.

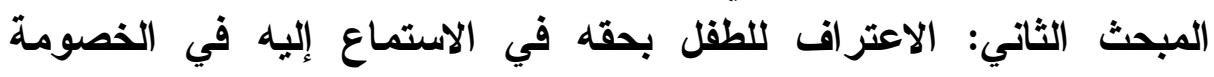
المدنية.

المبحث الثالث: مناط حق الطقل في الاستماع اليه في الخصومة المدنية. الفصل الثاني: الإطار الإجرائي لحق الطقل في الاستماع في الإنماع لإيه في في الخصومة المدنية

المبحث الأول: التظيم الإجرائي لحق الطقل في الاستماع إليه في الخصومة المدنية في التشريع الفرنسي.

المبحث الثاني: طبيعة مركز الطفل المستمع إليه في الخصومة الفئمئ المدنية ـ

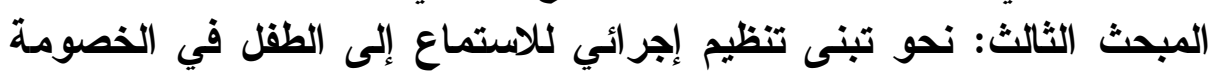

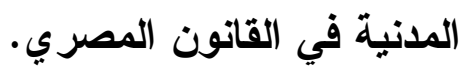




\section{الفصل الأول}

\section{التكريس القانوني لحق الطقل في الاستماع إليه في الخصومة المدنية}

بادئ ذي بدء، إن القو اعد العامة في قانون الإجر اءات المدنية لم تتبن

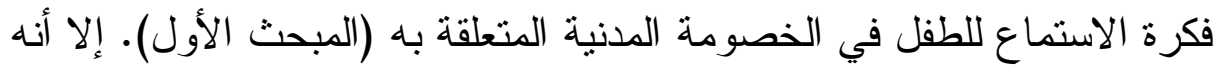
على ضوء التوقيع على الاتفاقات الدولية المعنية بحماية حقوق الطفل، فقد تم تكريس حق الطفل في الاستماع إليه في كل الإجر اءات المتعلقة به. و وعلي إثرات

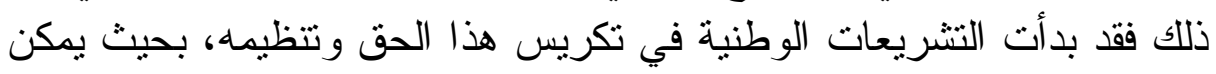

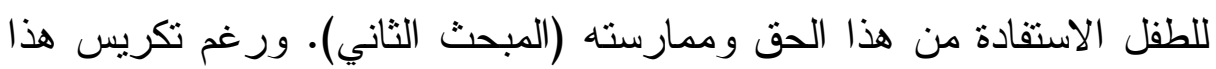

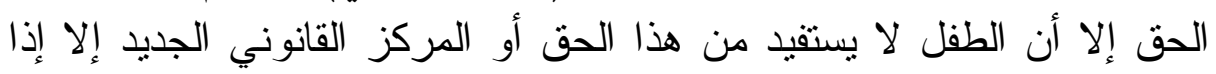

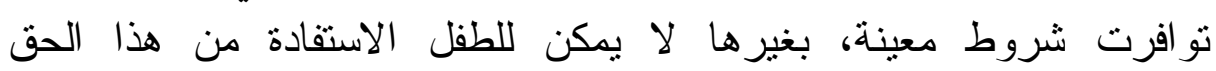

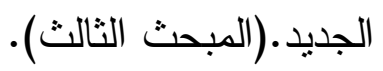

\section{المبحث الأول}

\section{مركز الطقل في الخصومة المدنية بصفة عامة}

يبدو من الضروري قبل التطرق لتحديد مركز الطفل في الخصومة

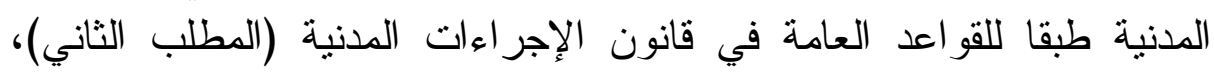
تحديد مفهوم الطفل في النظرية العامة للقانون( المطلب الأول).

$$
\text { المطلب الأول }
$$

\section{المفهوم القانوني للطقل}

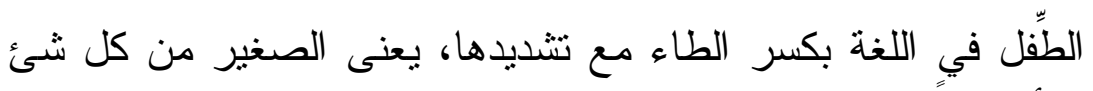

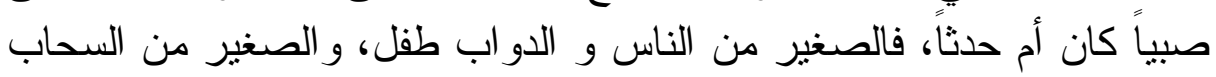

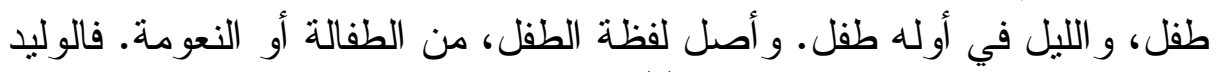
به طفالة ونعومة و اللايل فيدر طله طفل وألة (')

أما في اللغة الفرنسية فمصطلح طفل هو Enfant، وهي كلمة مشتقة من اللغة اللاتينية من مصطلح infans و الذى يعنى الثخص فلح الذى لا يتكلم

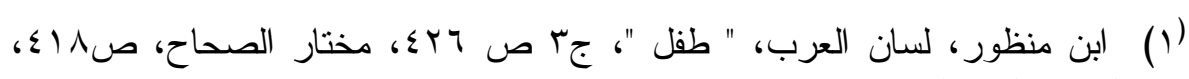

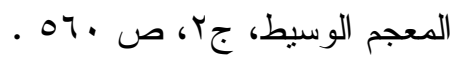


(') qui ne parle pas

و اختلف علماء الاجتماع في تعريف الطفل تبعاً لاختلاف وجهات

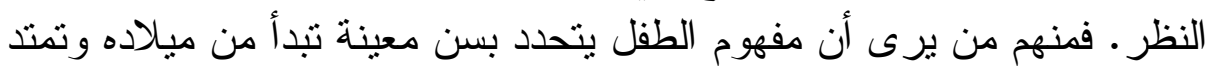

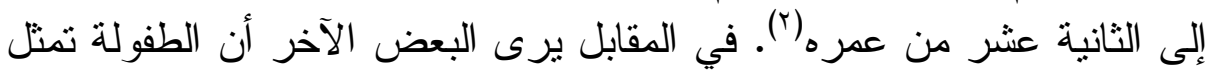

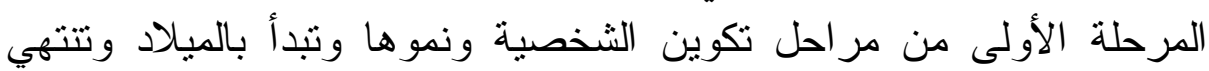

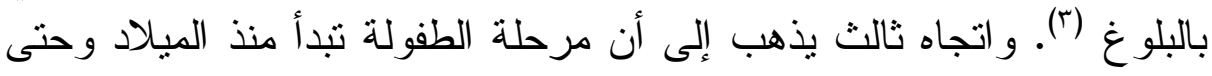

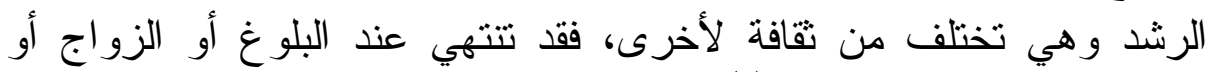

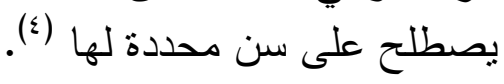

أما في الثريعة الإسلامية (0)، فإنه يستخلص من كتب الفقه الإسلامي أن مرحلة الطفولة هي تلك المرحلة التي تبدأ بتكوين الجنين في بطن أمه إلها

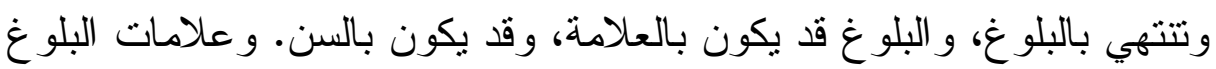

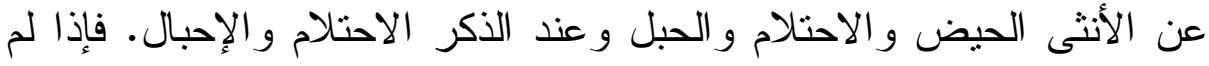
يوجد شيء من هذه العلامات الطبيعية كان البلوغ بالسن. وقد الختلف الفئ الفقهاء في تقديره.

فقدره أبو حنيفة في المشهور عنه بثماني عشرة سنة للفتى وسبع عشرة سنة للفتاة. وقدره الصاحبان و الجمهور بخمس عشرة سنة لكل من الفتى فئى فئه و الفتاة. في حين يذهب ابن حزم - رحمه الله - إلى تقديره بتسع عشرة سنة (?) (1)

(1) Le Petit Robert, 2007, Enfant P. 686.

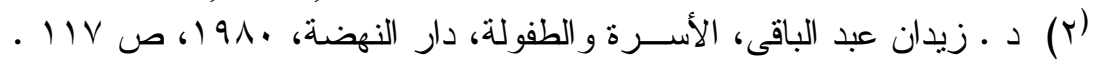

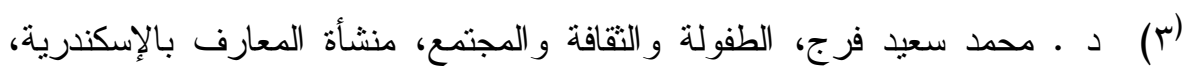

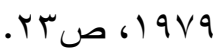

(§) د . عاطف غيث، قاموس علم الاجتماع، مادة " طفل " الهيئة المصرية العامة

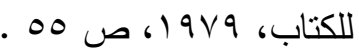

(ه) د ـ ـلالي عبـــ اللاه أحمد، حقوق الطفولة في الثريعة الإسلامية، مقارن و القانون

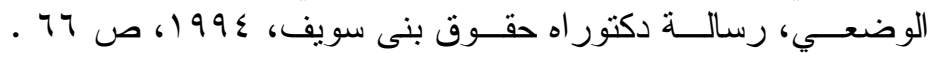

(') د ـ ـ نبيلة إسماعيل رسلان، حقوق الطفل في القانون المصري، دار النهضة العربية، . 


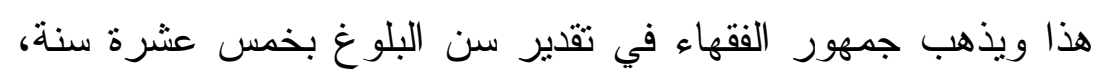

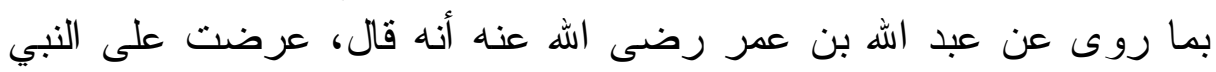

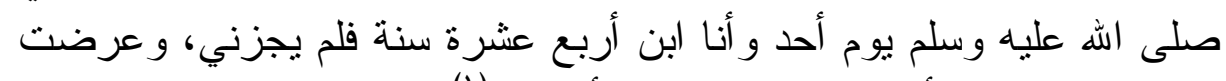

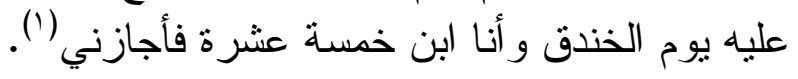

أما عن مفهوم الطفل في القانون الدولي، فإنه يمكن القول إنه قبل

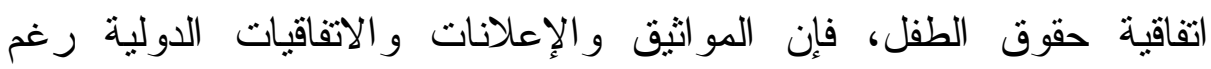

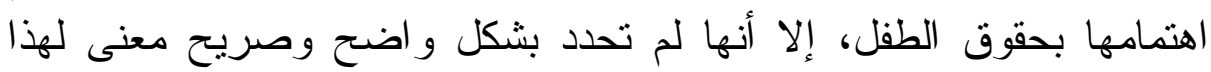

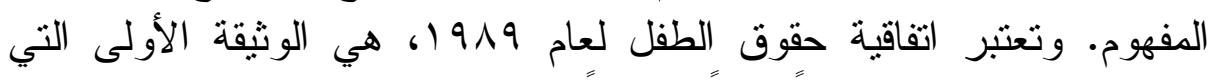

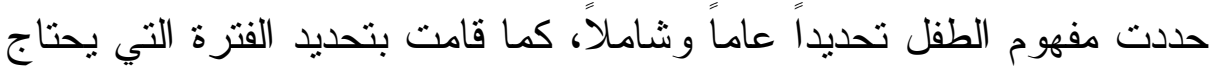
خلالها للحماية و الرعاية .وقد حددت المادة الأولى من هذه الاتفاقية الطفل بأنه

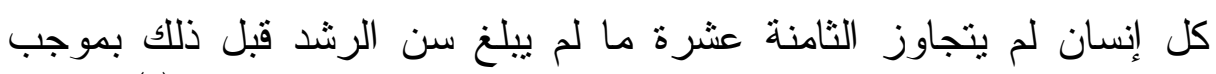

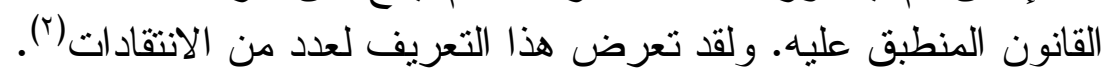
فأولاً أن الاتفاقية قد أهملت المرحلة الجنينية فلم تدخلها في مرحلة الطفولة، وذلك رغم أهمية هذه المرحلة بالنسبة للطفل. كما أنه من ناحية ثانية

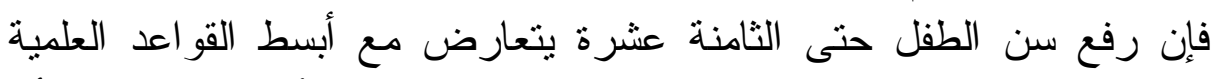

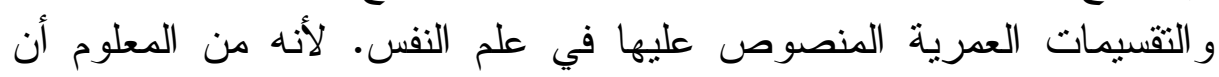
مرحلة الطفولة تنتهي بمرحلة البلوغ، لتبدأ مرحلة جديدة هي مرحلة المر الته الهقة.

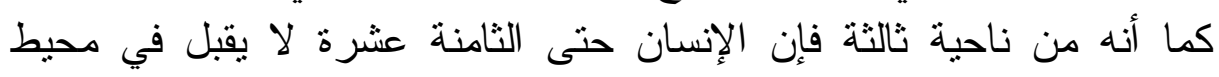

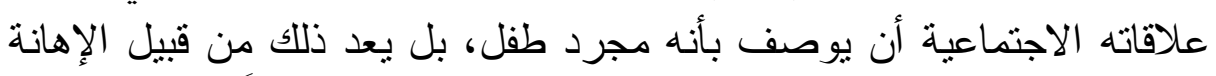

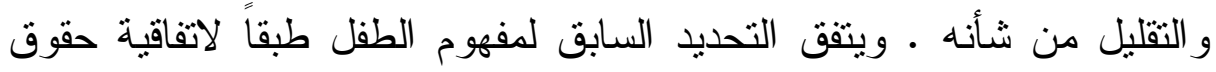
الطفل مع قو اعد القانون التي تحدد الطفل بالثخص الذي لثى لم يتجاوز سنه ثماني عشرة سنة.

أما في القانون المصري، فإن التقنين المدني يحدد مفهوم الطفل في

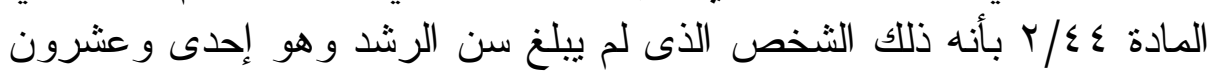

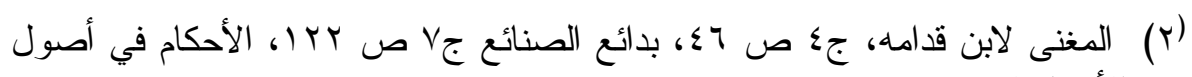

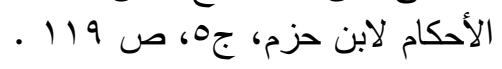

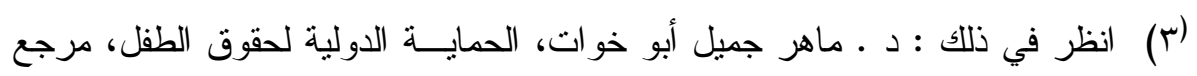

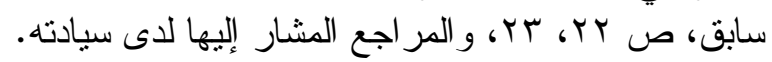


سنة ميلادية كاملة. حيث إن من لم يبلغ هذا السن تتبت له صفة الطفل طبقاً

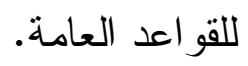

إلا إنه فيما يتعلق بقانون الطفل فإن المشرع نص في المادة الثانية

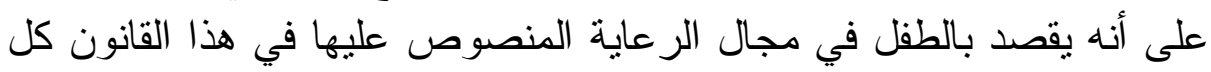

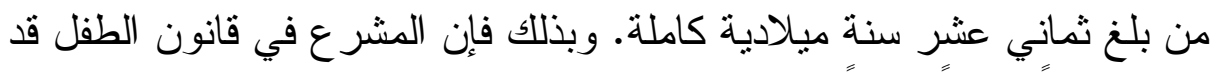

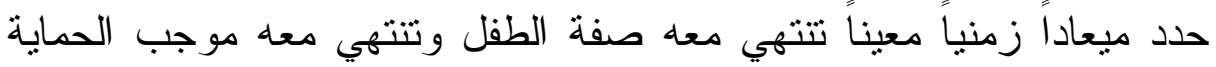

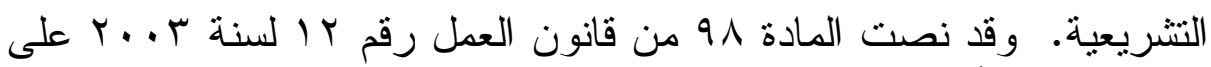

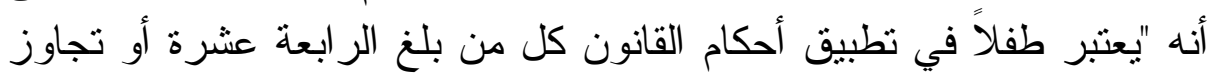

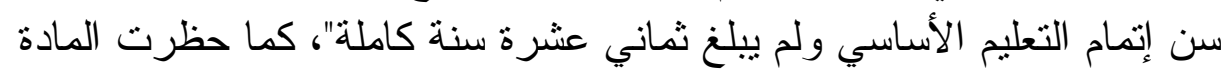

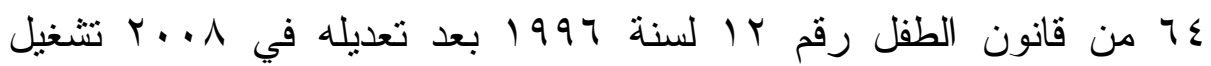
الأطفال قبل بلوغهم سن خمس عثرة سنة ومع ذللك يجوز تدريبهح متى بلغت سنهم ثلاث عشرة سنة.

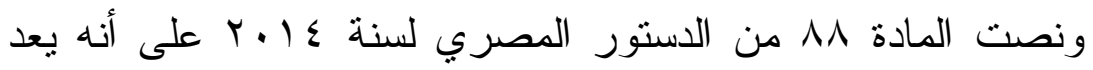

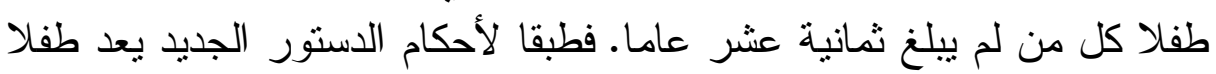

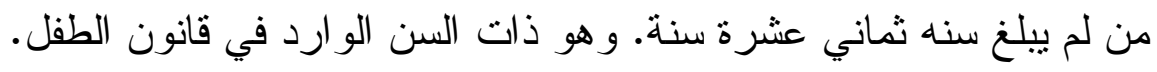
وفى القانون الفرنسي فإن المقصود بالطفل هو ذلك الثخص الذى لم يبلغ سن الثامنة عشر (')

\section{المطلب الثاني}

\section{تحديد المركز الإجرائي للطقل في الخصومة المدنية}

يقصد بالأهلية بصفة عامة صلاحية الثخص لاكتساب الحقوق

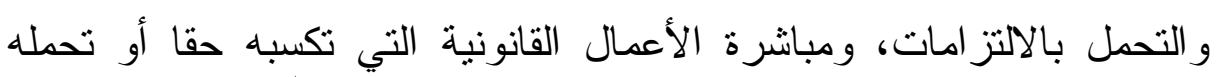

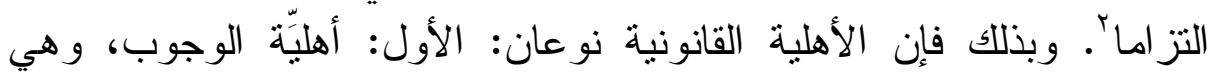

(1) J.-P. Gridel, L'âge et la capacité civile: D. 1998, chron. p. 90.

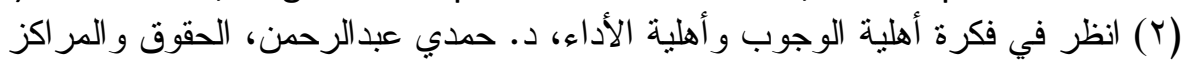

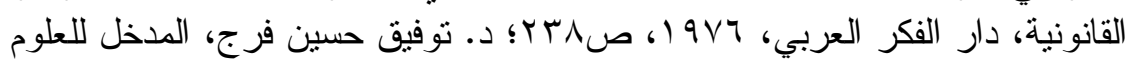

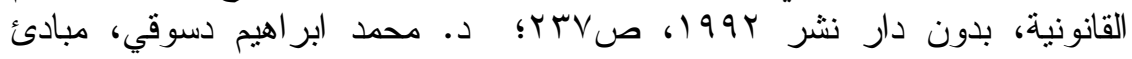

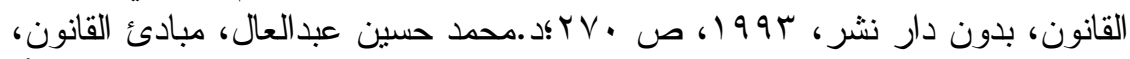

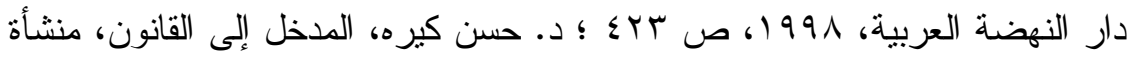

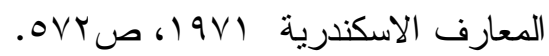


صلاحية الثخص لوجوب الحقوق المشروعة له وتحمله بالالنز امات القانونية.

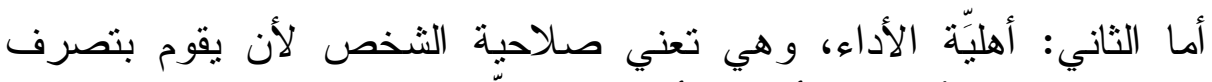

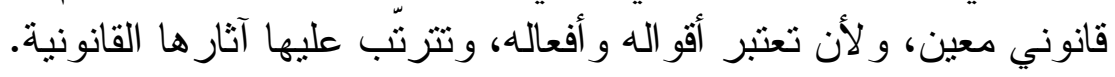

و إذا كان المشرع قد حدد المقصود بالأهلية فيما يتعلق بالمركز

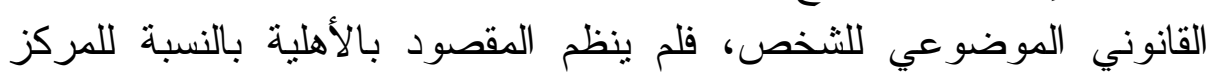

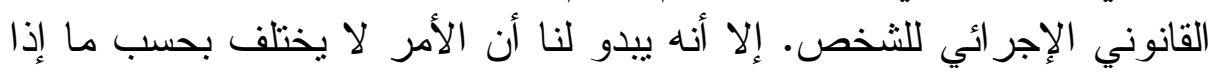

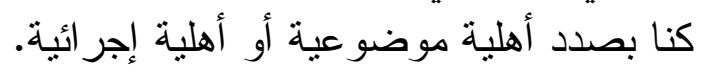

فتتقسم الأهلية الإجرائية أيضا إلى أهلية وجوب إجرائية وهي تعني صلاحية الثخص لاكتساب الحقوق الإجرائية وتحمل الالتزامات الإجة الإية ائية؛

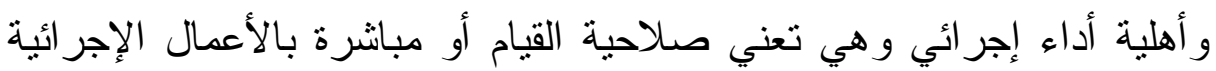

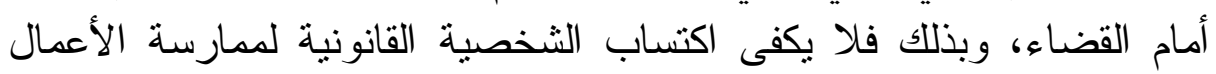
الإجرائية، بل يجب - فوق ذلك - توافر القدرة و الصلاحية على مباشرة الأعمال الإجر ائية.

ويشبه ذلك التفرقة بين أهلية الوجوب وأهلية الأداء المعروفة في

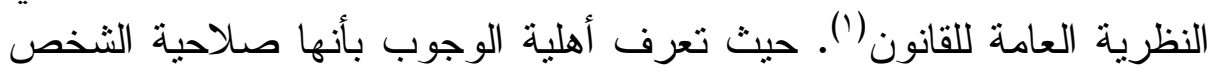

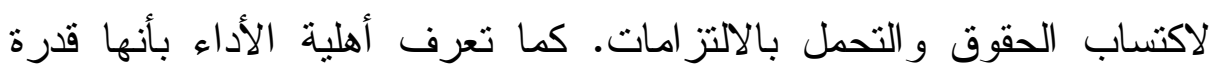
الثخص على توجيه إر ادته لإحداث أثنار قانونية لحسابه الخاص الخداص.

ولذللك فإنه يمكن التفرقة في القواعد العامة لقانون المر افعات بين

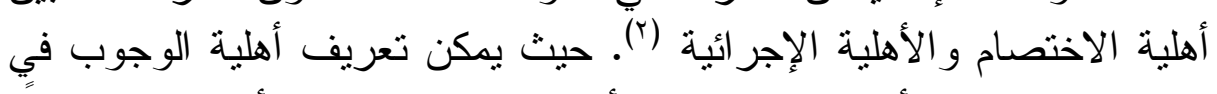

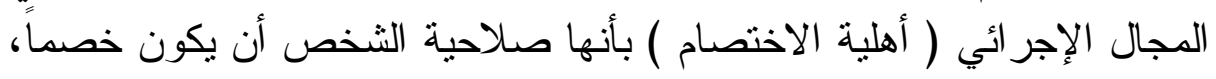

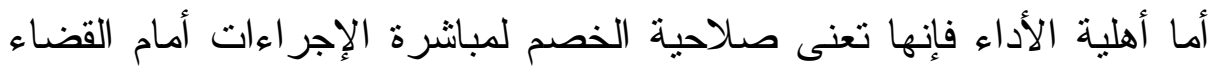

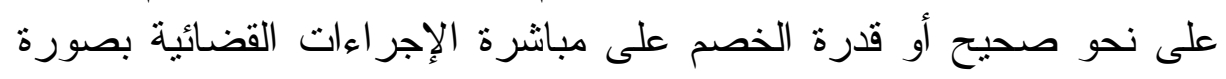

$$
\text { وفى الفقه الفرنسي: }
$$

G.Hubrecht, Droit civil, Edition Dalloz,1993, P.60., H.Roland et

L.Boyer, Introduction au droit, Litec, 2004, n 1015, p.410 . (1) انظر في ذلك : د. د. إبراهيم الثريعي، الصفة في الدفاع أمام القضاء الددني، دار

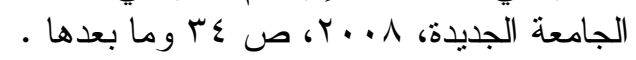

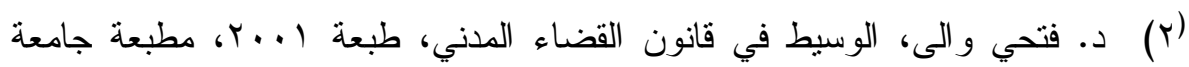

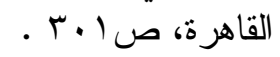


صحيحة(') أو بمعنى أخر تعنى صلاحية الخصم للقيام بعمل إجرائي سواء

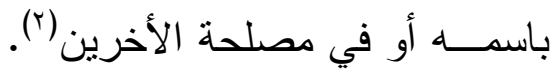

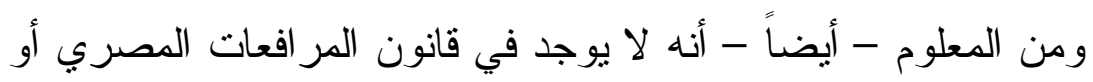

الفرنسي نصوص مباشرة تتعلق بالأهلية الإجرائية( أهلية الأداء الإجرائي).

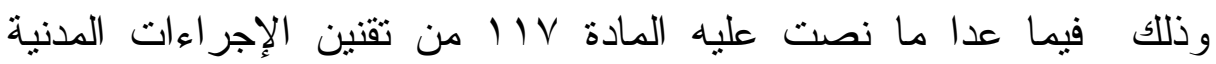

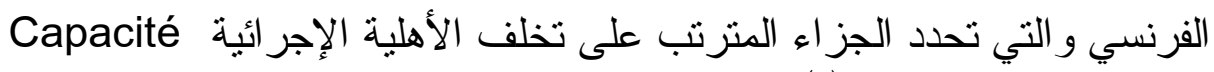
d'ester en justice

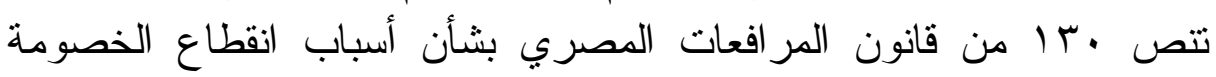

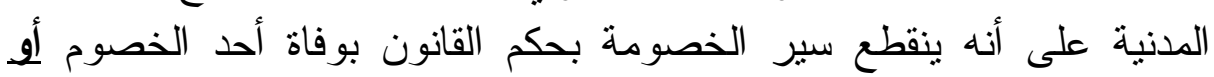

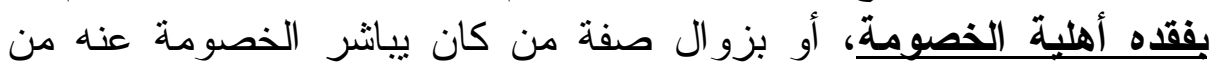

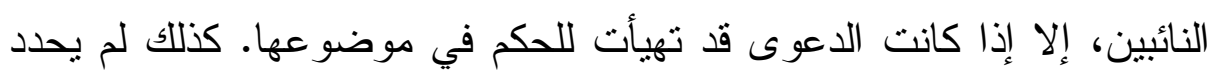
المشرع المصري مفهوم أهلية الخصومة. الخان.

و القاعدة أن أهلية الأداء الإجر ائي تتو افر لدى كل من تتو افر لديه أهلية

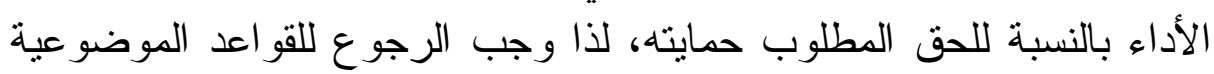

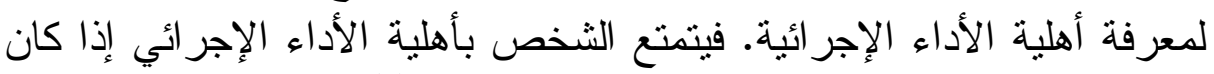

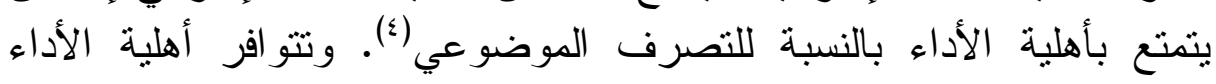

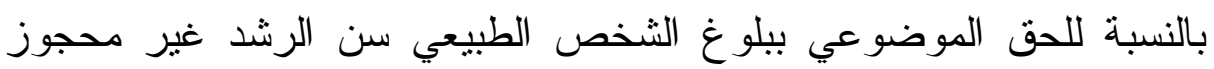

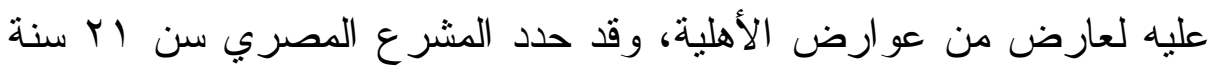

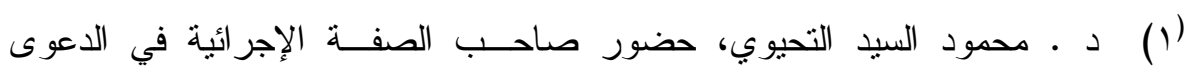

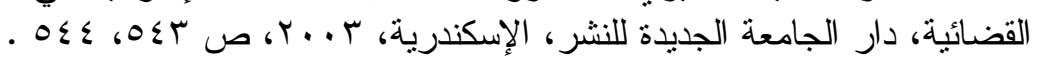

(2) Y. Desdevises, Action en justice, Condition de régularité de l'instance -

Capacité. Pouvoir., Juris-Cals.proc.civ.,fasc.126-3, 2012, n 10, p. 18.

(r) د. عبد محمد القصاص، الخلافة في الصفة الإجر ائية في المواد المدنية و التجارية، ص IV IV

P. Chevalier, "Parties á l'instance, Juris. Clas.proc.civ., fasc.124. 2002, p. 3.

(§) د. فتحي و الي، د. أحمد ماهر زغولة زلول، نظرية البطلان في قانون المر افعات، دار

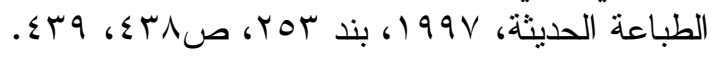




$$
\text { مبلادية بحسب نص المادة ؟ §/ من التقنين المدني. }
$$

و استثناء من ذلك في القانون المصري، تتص المادة الثانية من تقنين

إجراءات التقاضي في مسائل الأحو ال الثخصية على أنه ثنبت أهلية التقاضي في مسائل الأحو ال الثخصية للو لاية على النفس لمن أتم خمس عثرة سنة

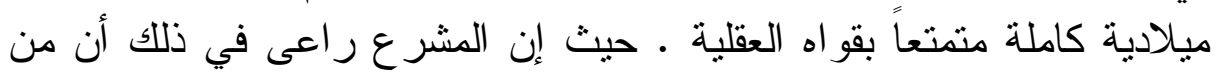
بلغ هذا السن يكون لله القدرة والإدراك ما بستطيع معه إفهام القاضي دعو اه خصوصاً في الدعاوى المتعلقة بالنفقات و الأجور و المصروفات بأنو اعها، وفى الإدى نفس الوقت فإنها وإن كانت سناً تعطيه أهلية إجرائية، وهي دون سن الأهلية الكاملة المحددة في القانون المدني، إلا أنها أهلية تسعف الصغير فيما يو اجه

من مشاكل (')

ويقتصر مجال أعمال هذا النص على مناز عات الأحو ال الثخصية

المتعلقة بالو لاية على النفس. و الاعتداد في تقرير سن المخاصمة القضائية لكل من بلغ خمس عشرة سنة مبلادية كاملة تتفق مع ما ورد بالمادة ع 7 من تقنين

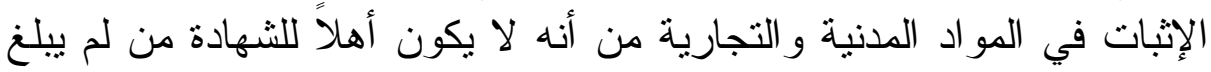
خمس عشرة سنة غير محجور عليه لعارض من عو ارض الأهلية. وبذلك فمن بلغ سن الخامسة عشر سنة من الخصوم - مدعياً أم مدعى عليه، لديه الصحلاحية للقيام بالأعمال الإجرائية أو تلقيها بالنسبة لخصومة الأحو ال الثخصية، بينما بفتقد هذه الصحلاحية في غير ها من الخصومات. فمن بلغ هذه السن يمكنه أن يرفع بنفسه دعوى نفقة أو نسب أو تحقيق وراثة ويحضر جلساتها ويباشر إجر اءاتها. بل إنه لا يصح القيام بهذه الأعمال الإجر ائية بو اسطة ممثله القانوني (r).

وفى العموم، فإنه يمكن القول بأن الثخص الطبيعي الذى لـ يبلغ سن

الو احدة و العشرون في القانون المصري و الذى لم يبلغ سن الثامنة عشرة في القانون الفرنسي، لا يمكن له - من حيث الأصل مباشرة الأعمال الإجرائية

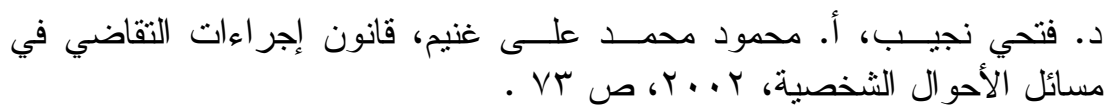

(Y) د .أحمد خليلٍ، خصوصيات التقاضي في مسائل الأحو ال الثخصية المتعلقة بالو لاية

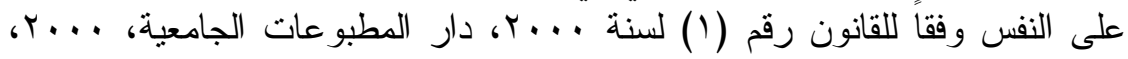
ص ص اr 
و لا تثبت له الأهلية الإجرائية Capacité processuelle . إلا أن ذلك لا يحرمه من حقه في التقاضي وحماية حقوقه الموضو عية، حيث يثبت للقاصر الإنة الحق في ممارسة حقه في التقاضي عن طريق ممثليه القانونيين.

حيث إن الثخص الذى لديه أهلية الاختصام ولا تتو افر لديه الأهلية

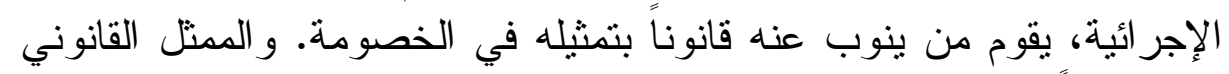

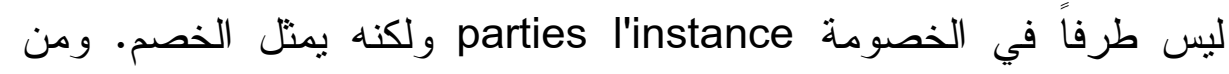
ناحية أخرى ليس لهذا الممثل صفة في في الدعوى، فصفته تكون فقط صفة

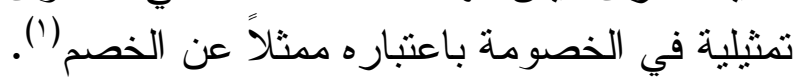

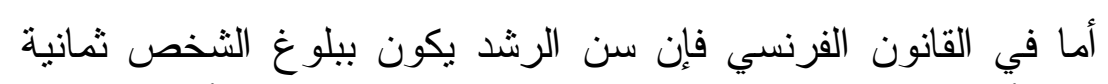

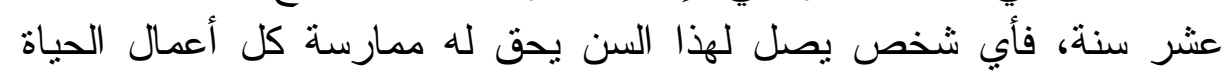

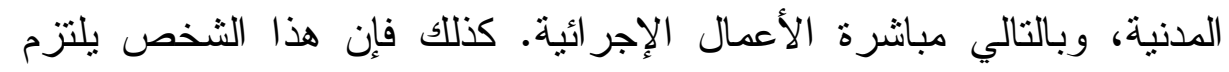

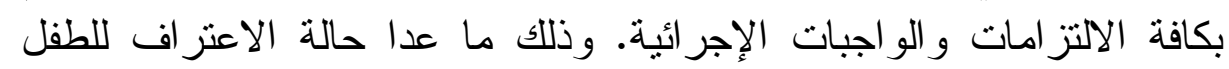

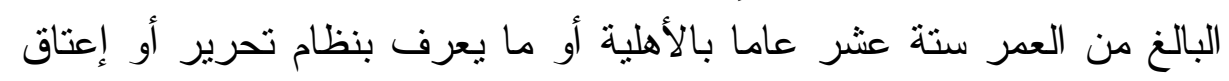

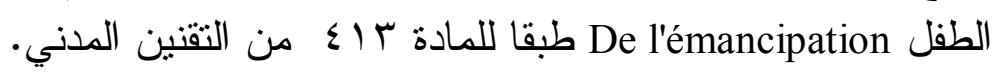
ورغم ذلك فقد أقر المشرع الفرنسي عدة حالات تثبت فيها للقاصر

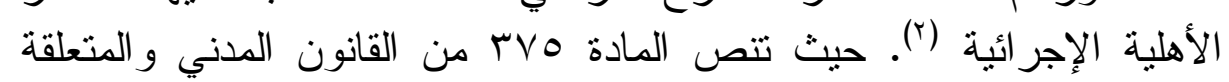

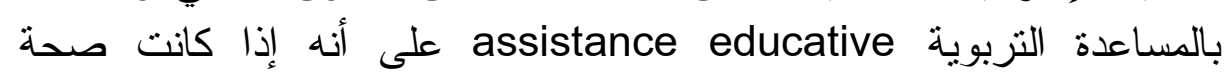

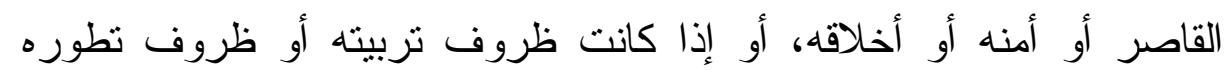

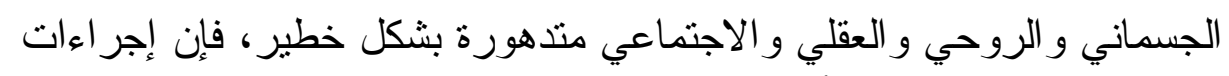

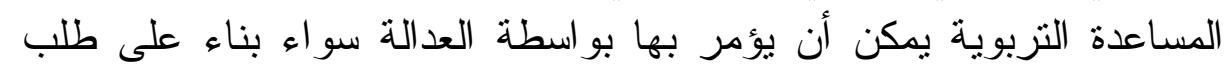

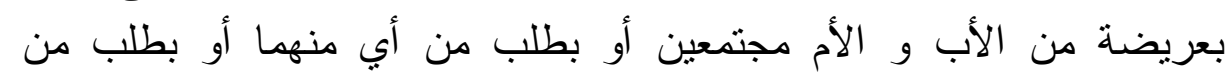

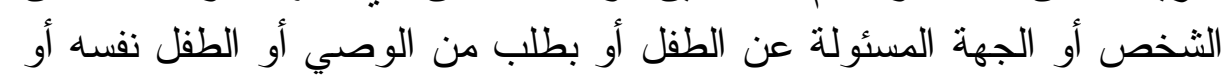

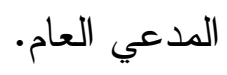

Si la santé, la sécurité ou la moralité d'un mineur non émancipé

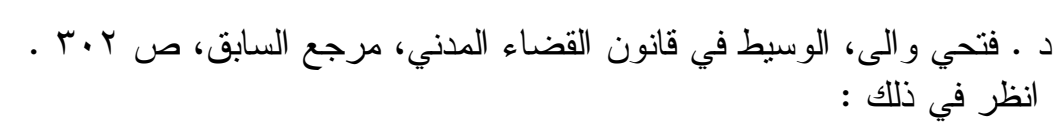

C.Watine - Drouin, Minorité, audition du mineur en justice, Défense de ses interest, Fasc.unique, Jur. Clas. civil code, art. 388.1 et $388.2,2009$, no $96, p .42$. 
sont en danger, ou si les conditions de son éducation ou de son développement physique, affectif, intellectuel et social sont gravement compromises, des mesures d'assistance éducative peuvent être ordonnées par justice à la requête des père et mère conjointement, ou de l'un d'eux, de la personne ou du service à qui l'enfant a été confié ou du tuteur, du mineur lui-même ou du ministère public

كذلك فإنه طبقاً للمادة 11 1 1 و المادة r/11 من التقنين المدني فإنه

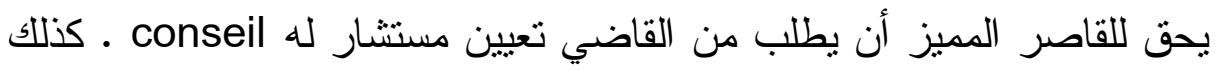

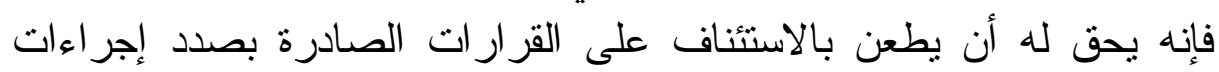

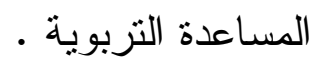

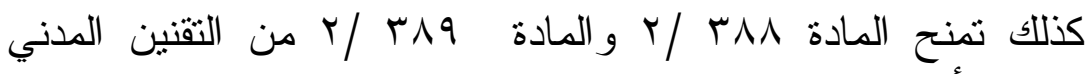

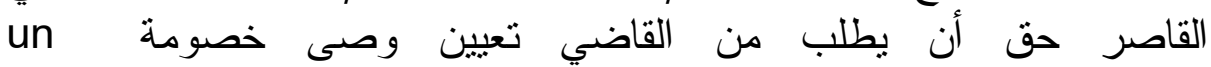
administrateur ad hoc

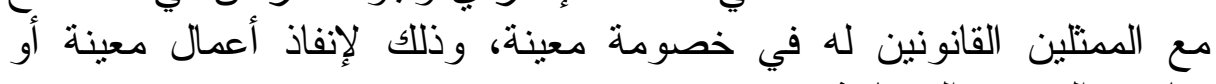
مبانشرة الدعوى القضائية.

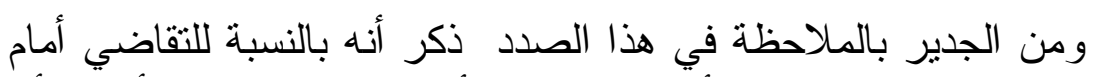

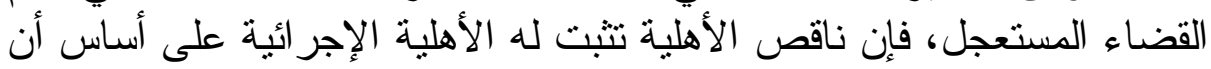

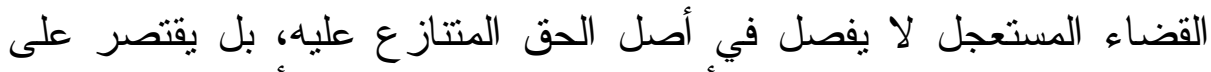

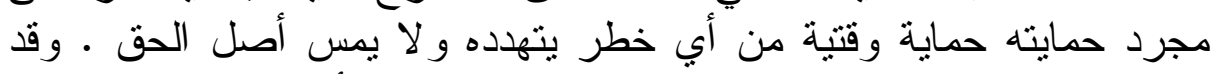

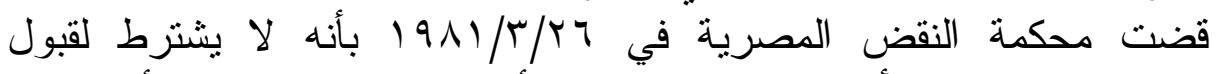

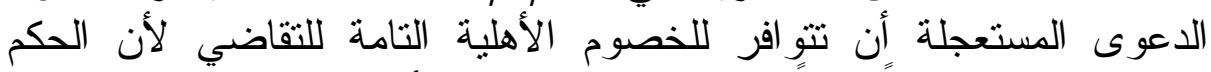

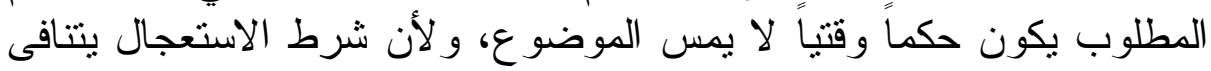

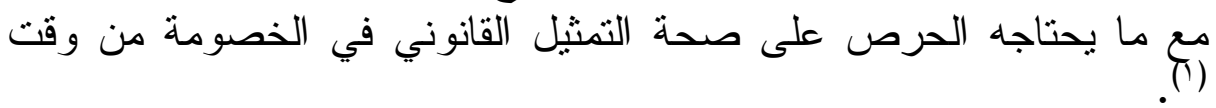

وذات الأمر ينطبق على دعاوى الحيازة، إذٍِ تثبت الأهلية الإجرائية لناقص الأهلية، وذلك لأن هذه الدعاوى لا تحمى حقاً موضو عياً و إنما محلها لإحها

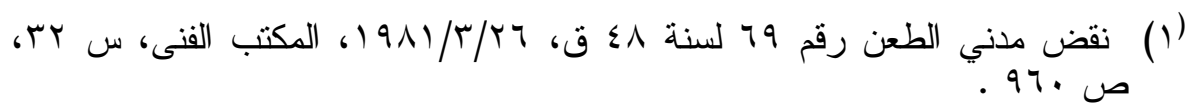




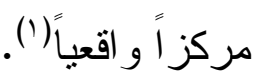

ومن المقرر في هذا الصدد أن الأهلية الإجرائية ليست شرطاً فقط

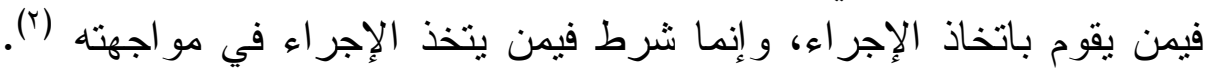

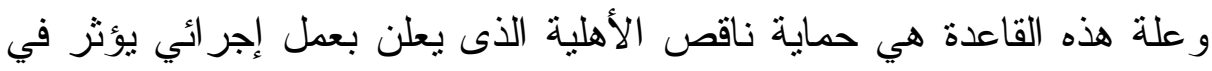

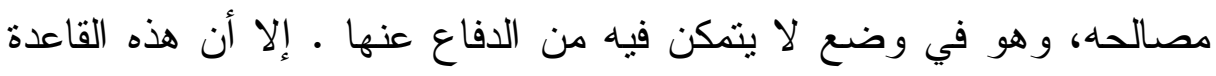

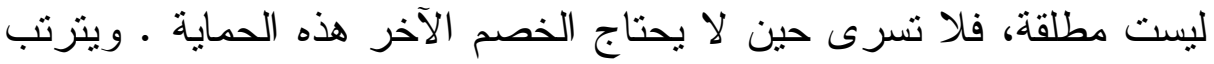

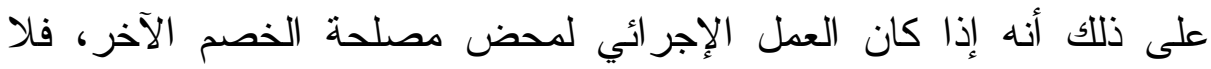
تشنترط الأهلية الإجرائية إلا فيمن أصدر العمل. ومثال ذلك الإن الإقرار القضائي (r).

ويثور التساؤل - في هذا المقام - حول أثز تخلف الأهلية الإجر ائية

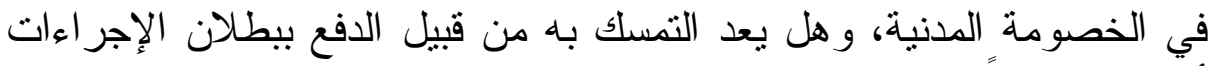

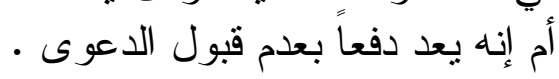

ومن المعلوم أن الدفع ببطلان الإجراءات من الدفوع الثكلية، ويستهدف به الطعن في الخصومة والإجراءات المكونة لها، ورلا يوجاه

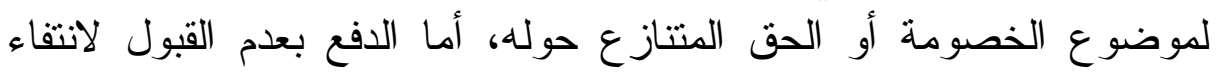

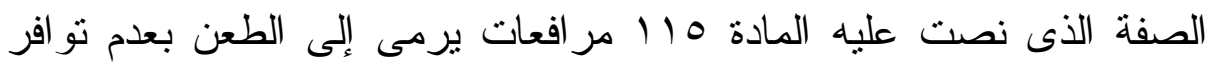

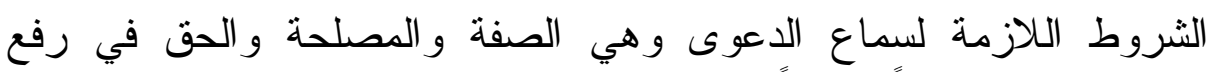

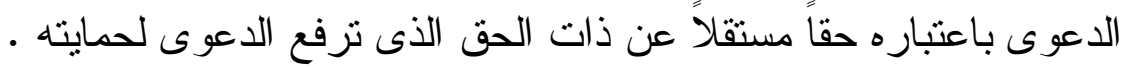

وقد اختلف الفقهاء في شأن أثزر عدم تو افر الأهلية الإجر ائية (£)، فذهب

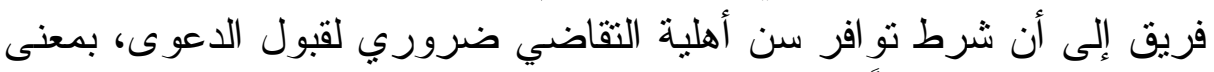

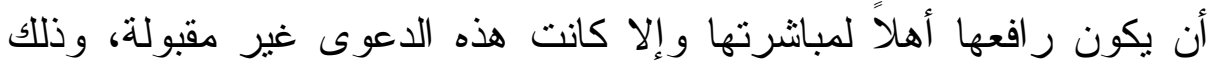

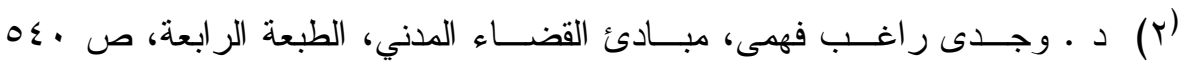

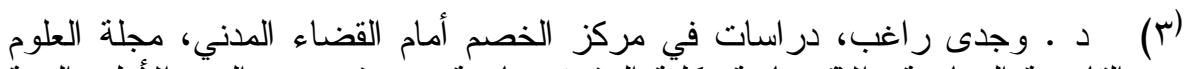
القانونية السياسية و الاقتصادية، كلية الحقوق جامعة عين شمس - العدد الأول، السنة العادم $.19 \vee 7611$

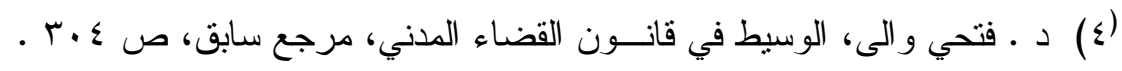

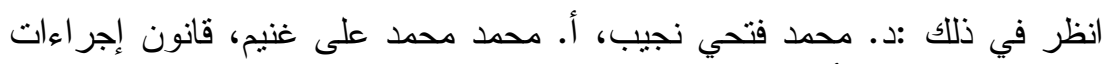

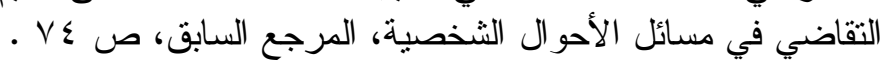


استتاداً إلى أنها تعتبر مرفوعة من غير صفة، وعلى اعتبار أن من لم يبلغ هذه السن لا صفة له في الزود عن حقه لنه (1).

بينما يذهب فريق آخر إلى أن الأهلية ليست شرطاً لقبول الدعوى

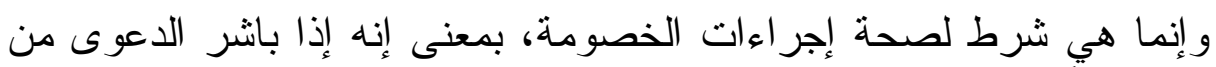
ليس أهلاً لمباشرتها كانت دعو اه مقبولة ولكن إجراءات الخصومة تعد باطلة

حيث لا شأن للأهلية بشروط قبول الدعوى، فالأهلية تتعلق بصلاحية القيام بالإجر اءات القضائية على نحو صحيح . فالأهلية لا تؤثر في شروط قبول الدعوى، وإنما تؤثر في إجراءاتها، فإذا فقد الخصم أهليته أثتاء الخصومة تتقطع هذه الخصومة، ولا نتأثز الدعوى بل يمكن تحريكها في مواجهة الممنل القانوني للخصم بعد ذلك. و إذا كان الراجح في الفقه أن الدفع بتخلف الأهلية الإجرائية في الخصومة المدنية بعد من قبيل الدفوع ببطلان الأعمال الإجر ائية". الإن.

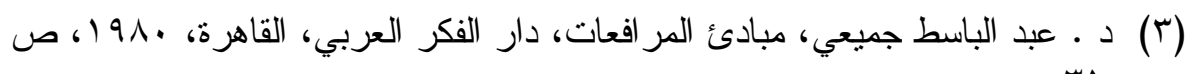

( ) د. إير اهيم الثريعى، الصفة في الدفاع أمام القضاء المدني، دار الجامعة الجديدة،

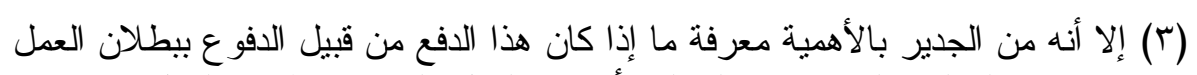

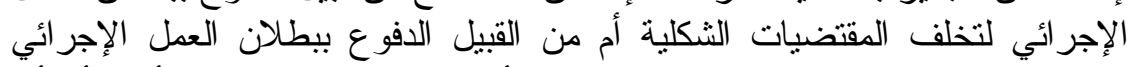

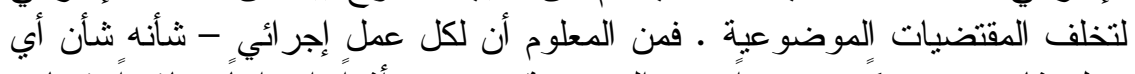

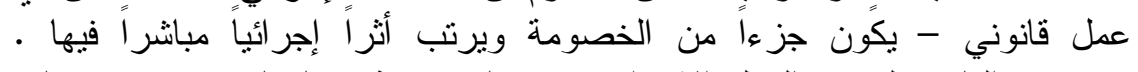

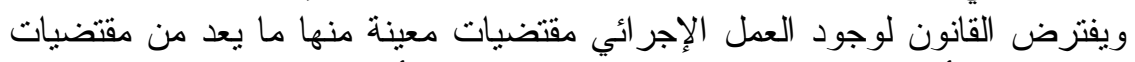

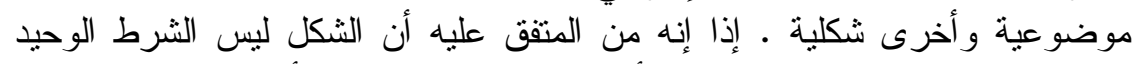

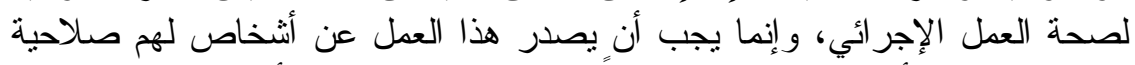

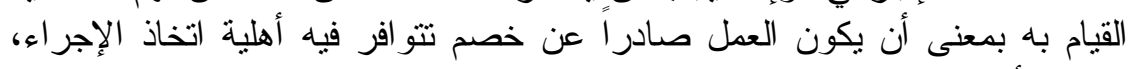

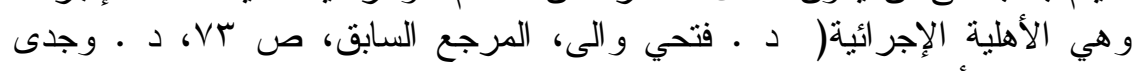

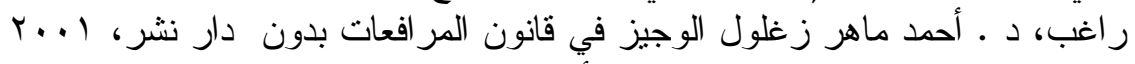

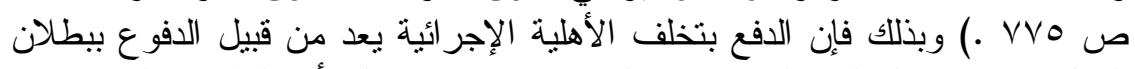

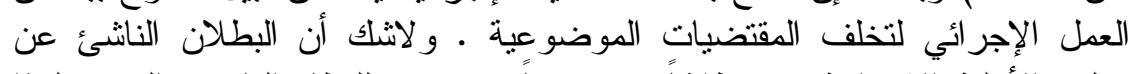

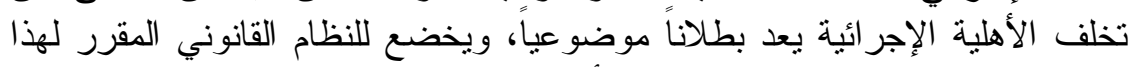

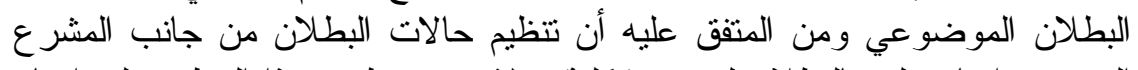
المصري إنما يتعلق بالبطلان لعيوب شكلية، ولا يجوز تطبيق هذا التتظيم على انتفاء 
مما سبــق يتضـح كقاعــدة أن الطفل تثبــت له أهلية الاختصام(أهلية الوجوب) أمام القضاء المدني - سو اء في القانون المصري أو القانون الفرنسي - إلا إنه لا تثبت لله الأهلية الإجر ائية كأهلية الأداء، فلا بستطيع أن

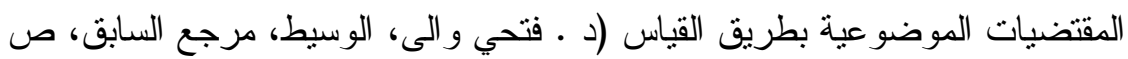

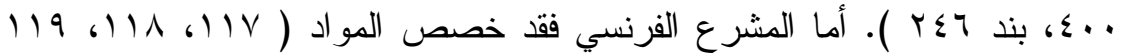

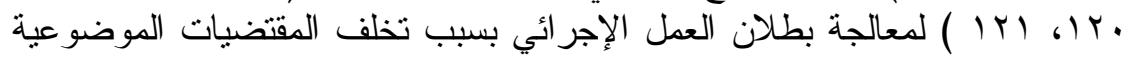

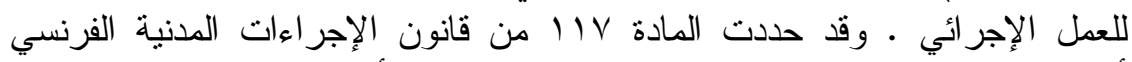

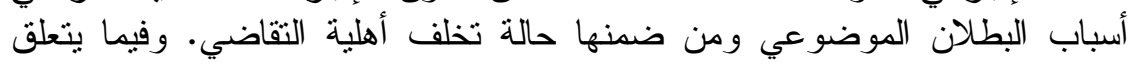

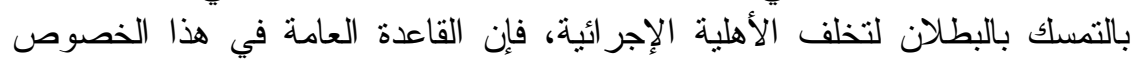

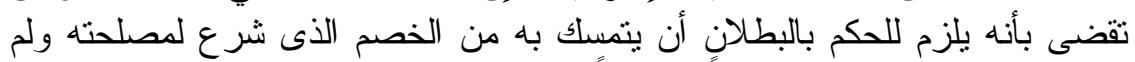

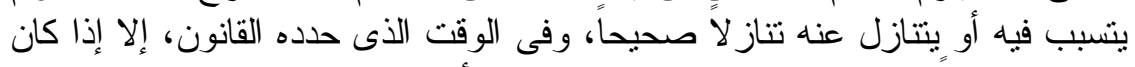

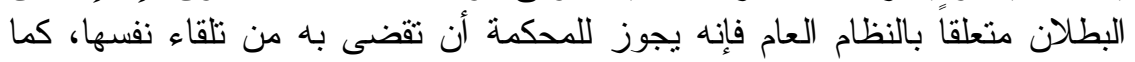

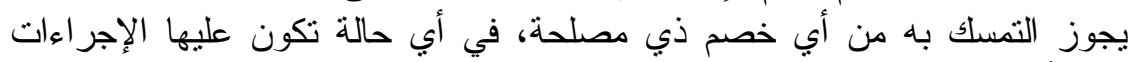

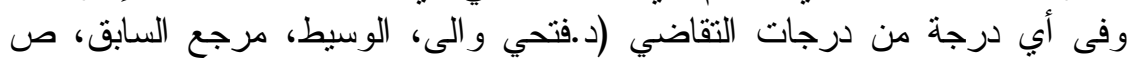

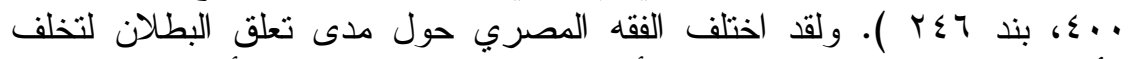

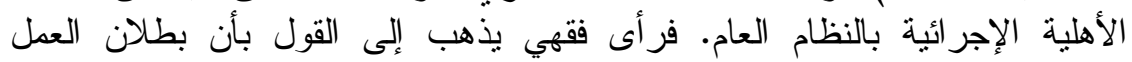

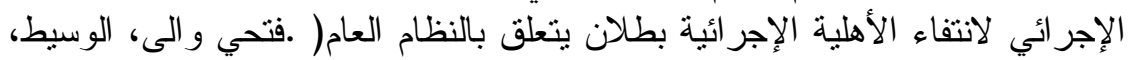

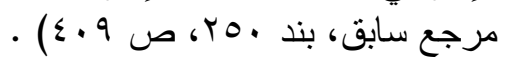

ويذهب رأى ثان(r) (وجدى راغب، دراسات في مركز الخصم أمام القضاء المدني،

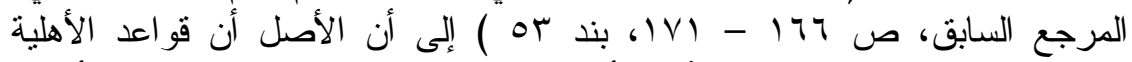

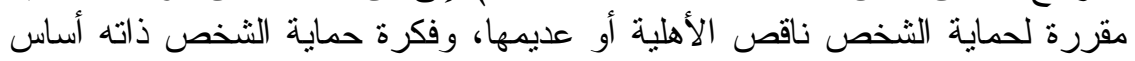

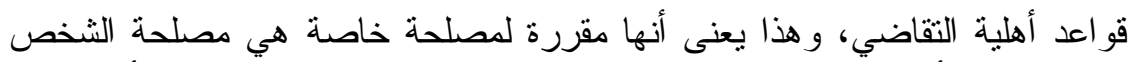

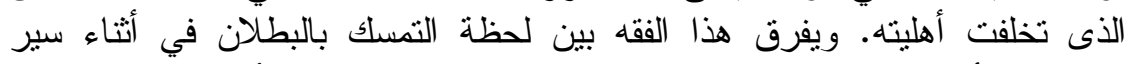

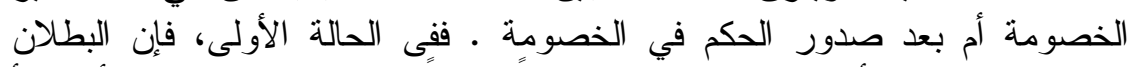

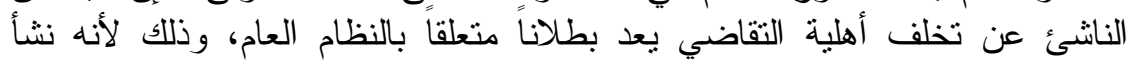

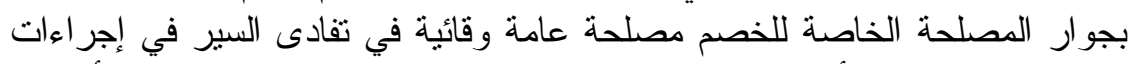

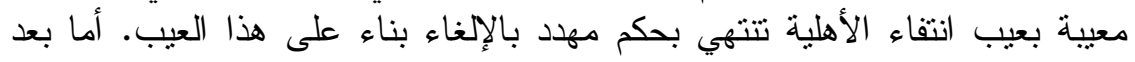

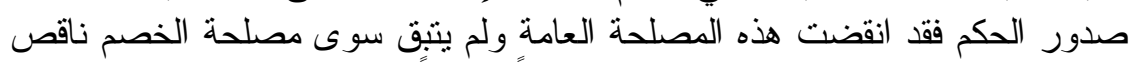

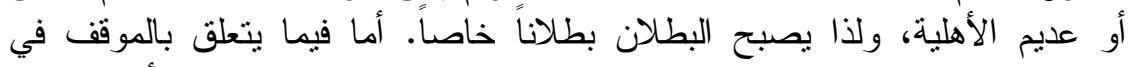

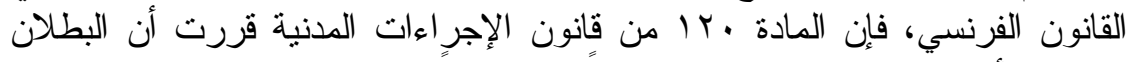

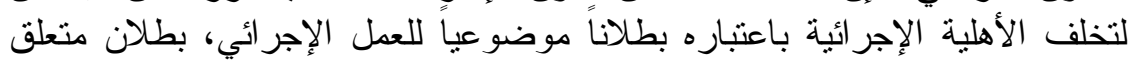

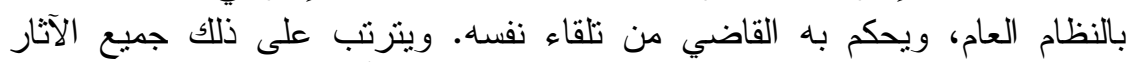

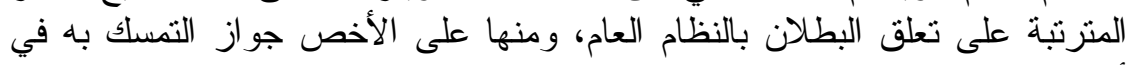

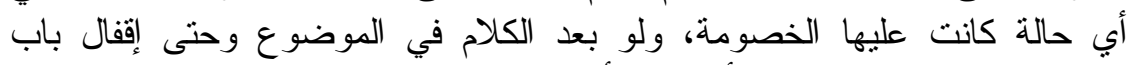

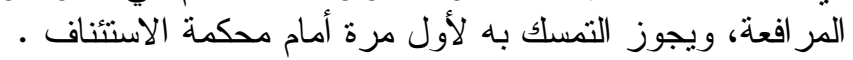


يباشر إجر اءات الخصومة بنفسه، إلا أن ذلك لا يحرمه من حقه في التقاضي و الدفاع عن مصالحه عن طريق ممثله القانوني.

ولم تكرس القو اعد العامة في قانون الإجر اءات المدنية سواء المصري

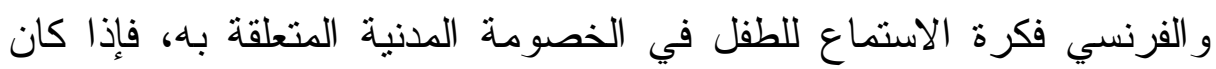

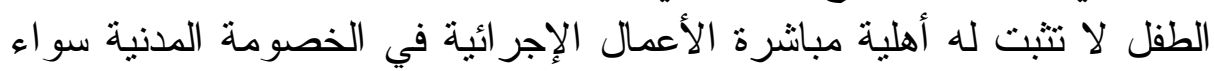

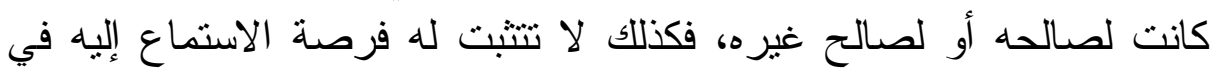

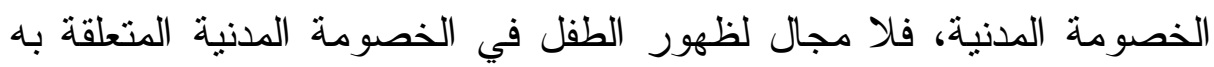
طبقا للقو اعد العامة، فلم تكرس النصوص فلدة العامة هذه الفكرة.

\section{المبحث الثاني}

\section{الأسساس القانوني لحق الطقل في الاستماع إليه في الخصومة المدنية}

لقد اعترفت الاتفاقية الدولية لحماية حقوق الطفل بحق الطفل في الاستماع إليه ليس فقط في الخصومة المدنية بل في كل الإجراءات الإله المتعلقة

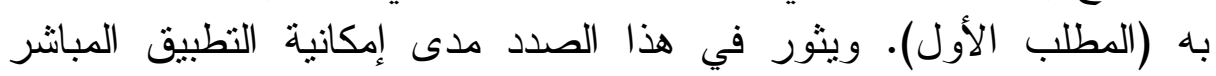
للأحكام المقررة لهذا الحق في الاتفاقية الدولية في كل من الني النظام القانوني

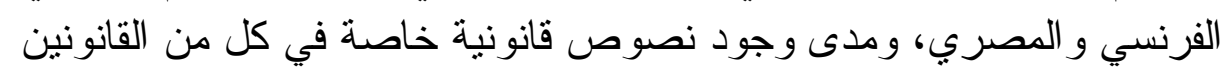
تكرس لهذا الحق (المطلب الثاني).

\section{المطلب الأول}

إقرار الاتفاقية الدولية لحماية حقوق الطقل

\section{لحق الطقل في الاستماع إليه في الإجراعات المتعلقة به}

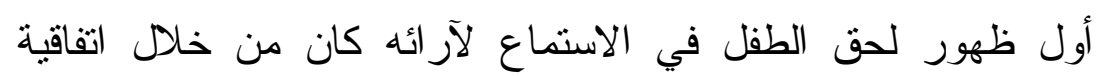

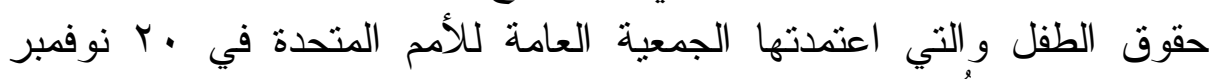

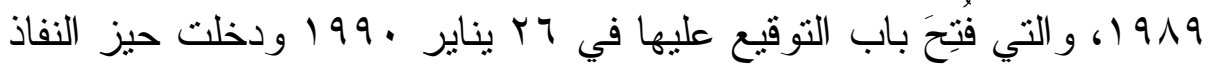

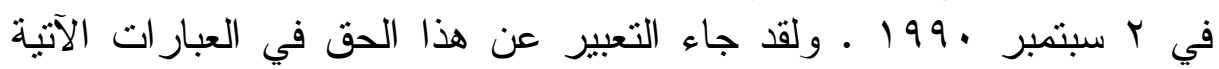

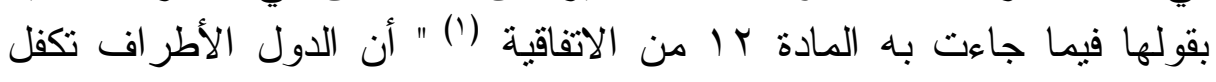

(1) (1) ويأنى نص هذه المادة في اللغة الإنجليزية كما يلى : (1)

1- States parties shall assure to the child who is capable of forming his or her views the right to express those views in all 


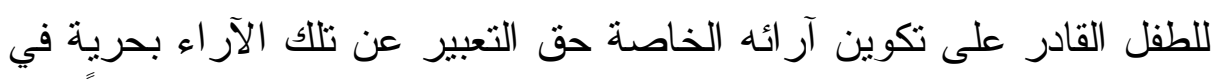

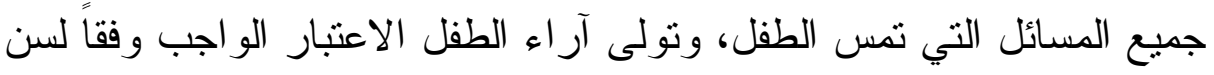

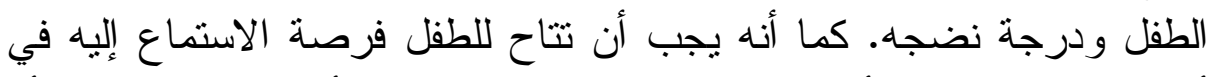

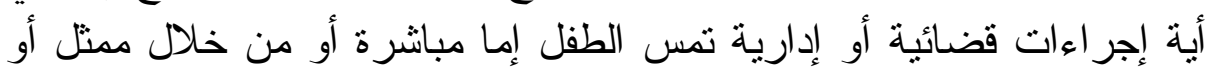

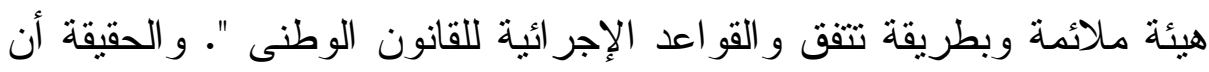

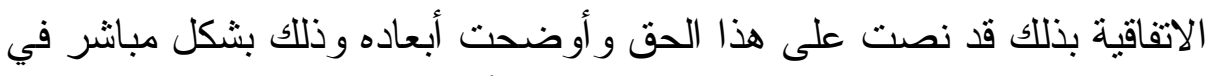

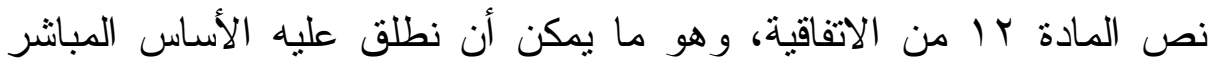
لحق الطفل في الاستماع إليه في الإجراءات المات المتعلقة به فيه في الاتفاقية الدولية.

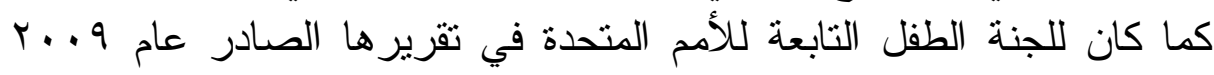

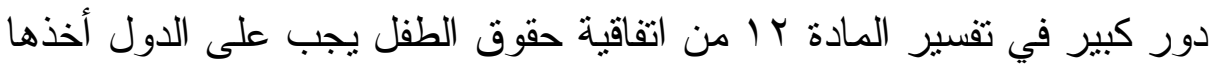

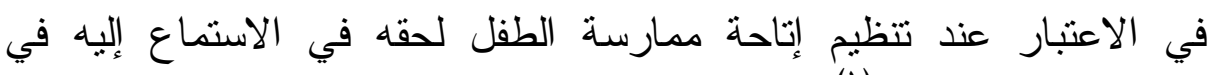
الإجر اءات المتعلقة به (').

maters affecting the child, the views of the child being given due weight in accordance with the age and maturity of the child.

2 - For this purpose, the child shall in particular be provided the opportunity to be heard in any judicial and administrative proceeding affecting the child, either directly, or through a representative or an appropriate body, in a manner consistent with the procedural rules of national law.

$$
\text { ويأني النص باللغة الفرنسية على النحو التالي: }
$$

«1. Les États parties garantissent à l'enfant qui est capable de discernement le droit d'exprimer librement son opinion sur toute question l'intéressant, les opinions de l'enfant étant dûment prises en considération eu égard à son âge et à son degré de maturité.

2. À cette fin, on donnera notamment à l'enfant la possibilité d'être entendu dans toute procédure judiciaire ou administrative l'intéressant, soit directement, soit par l'intermédiaire d'un représentant ou d'une organisation approprié, de façon compatible avec les règles de procédure de la législation nationale.».

(1) انظر تقرير لجنة حقوق الطفل التابعة للأكم المتحدة (الدورة الواحدة والخمسين)

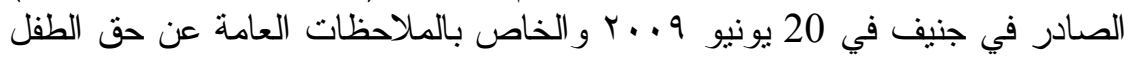

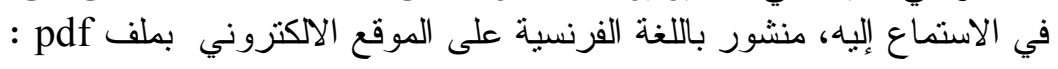


العدد الأول- الجزء الأول- السنة الثامنة والخمسون- يناير 14.r =

الفرع الأول

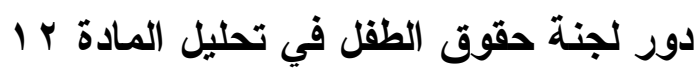

المكرسة لحق الطقل في الاستماع إليه في الإجراعات المتعلقة به

الوارد في الاقفاقية الدولية لحماية حقوق الطقل

أقرت الفقرة الأولى من المادة ب ا من اتفاقية حقوق الطفل حق الطفل

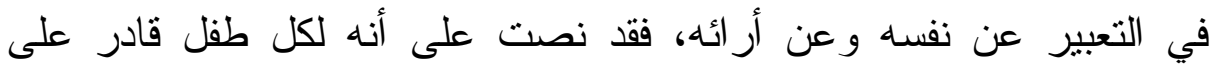

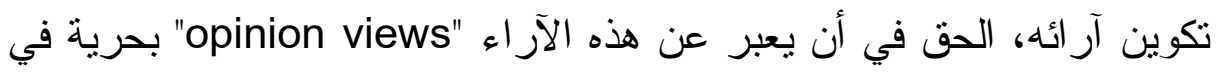

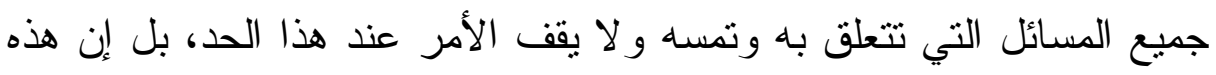

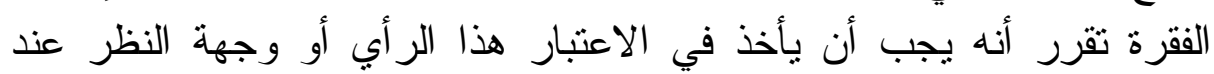

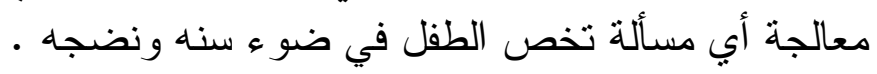

ثم جاءت الفقرة الثانية، وقررت صراحة حق الطفل في أن تسمع

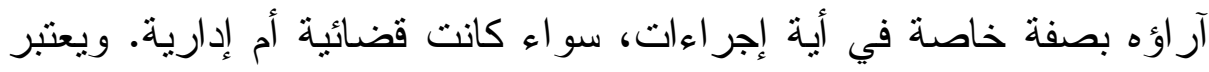

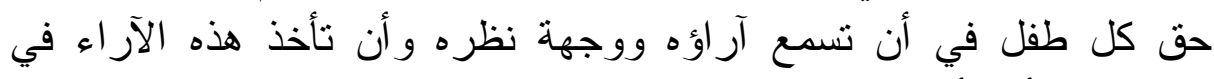
الاعتبار - أحد أهم القيم التي جاءت بها اتفاقية حقوق الطفل . حيث اعتبرتها

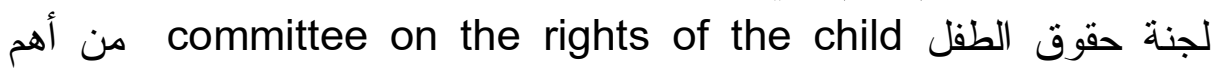
the right أربعة مبادئ عامة للاتفاقية ـ فبالإضافة إلى الحق في عدم التمبيز the right to life و والحق في الحياة والتطوير to non-discrimination

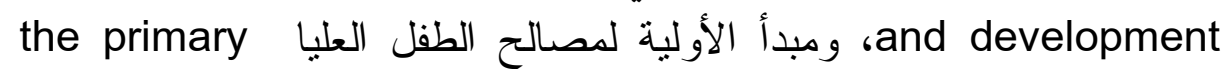
. consideration of the child's best interests

فإن حق الطفل في الاستماع إليه وأخذ آرائه في الاعتبار يأتي في المرتبة الر ابعة.

و هذا النص لا يترك فرصة للدول الأطر اف التي وقعت على هذه

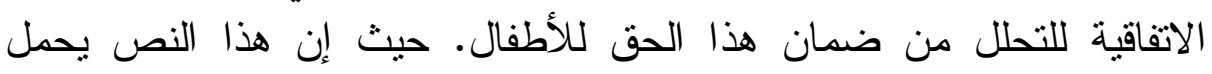

http://www.google.com.eg/url?sa=t\&rct=j\&q=\&esrc=s\&source=w eb\&cd=1\&ved=0ahUKEwjFrsu3pMzLAhVCORoKHcQkBu0QFg gaMAA\&url=http $\% 3 \mathrm{~A} \% 2 \mathrm{~F} \% 2 \mathrm{Fwww}$.ohchr.org\%2Fenglish $\% 2 \mathrm{~F}$ bodies $\% 2 \mathrm{Fcrc} \% 2 \mathrm{Fdocs} \% 2 \mathrm{FAdvanceVersions} \% 2 \mathrm{FCRC}-\mathrm{C}-\mathrm{GC}-$ 12_fr.pdf\&usg=AFQjCNGMzx_5U7bYJifi-F93dHa3e7ncUw 
التزاماً علي عاتق الدول الأطراف باتخاذ الإجراءات المناسبة حتى يستقيد الطفل كاملاً من حقه في الاستماع إلى أقو اله و آر ائه.

وهذا الالتزام يتضمن عنصرين هامين، الأول يتمثل في أن يكفل

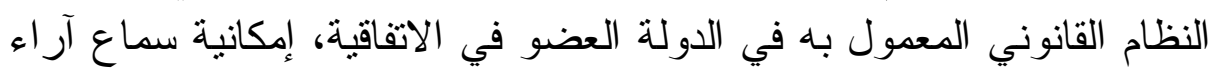

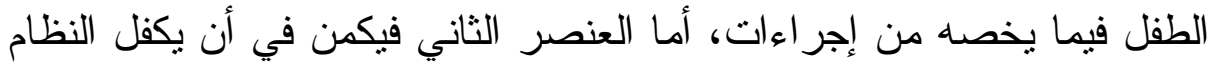

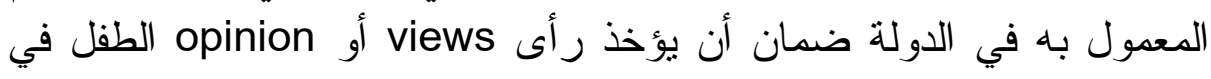
الاعتبار عند اتخاذ القر ار الذى يمس الطفل.

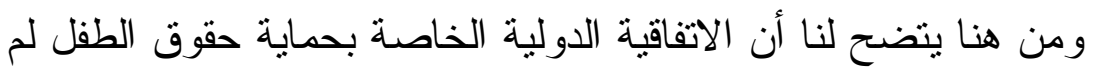

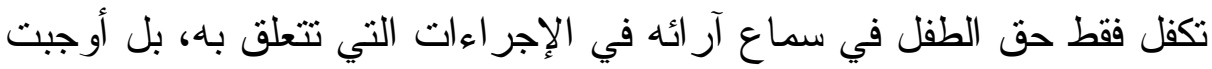
أن يؤخذ هذا الر أي في الاعتبار عند إنفاذ الموقف أو الر القر ار الذي الذي يمس الطفل.

ولم يقتصر مضمون المادة الثانية عثر من اتفاقية حقوق الطفل على الطى

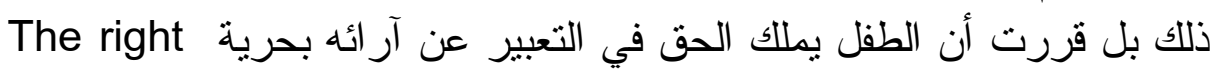
to express those views freely يستطيع أن يعبر عن رأيه بدون ضغوط، وأنه يستطيع أن يختار بين ما لئ إذا

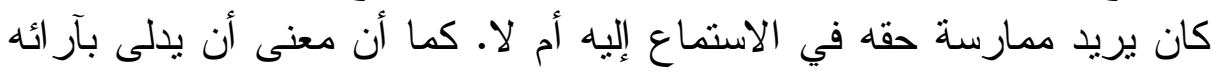

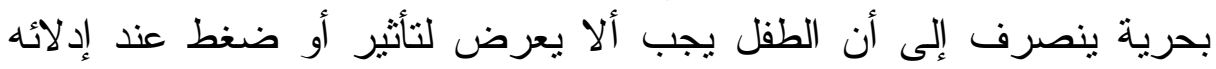

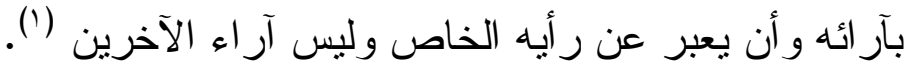

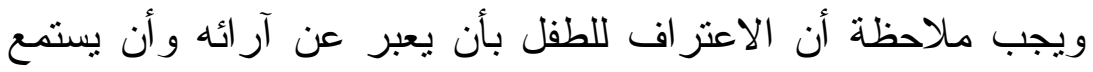

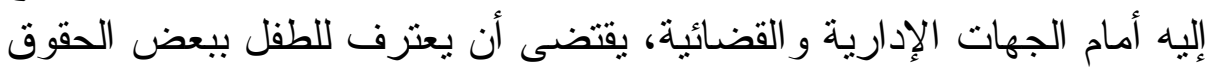

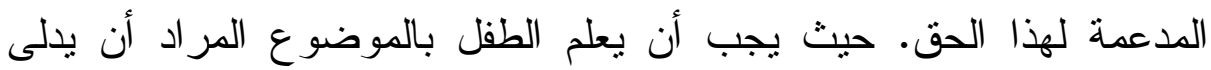

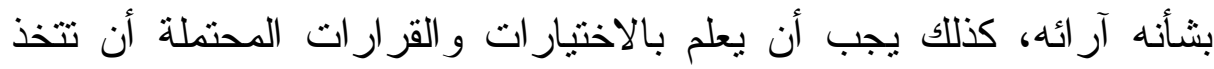

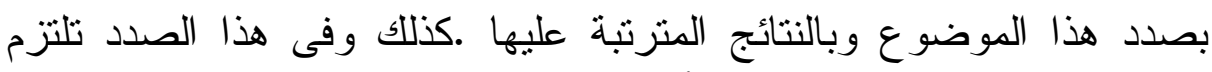

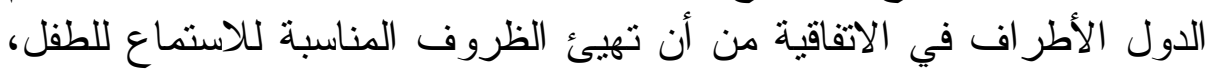
كذللك فإن الطفل يجب أن يعلم بالثروط و الظروف التي سوف يتم سماع آن آرائه على ضوئها.

(1) Comité des droits de l'enfant, cinquante et unième session, Genève 25 mai 12 Juin 2009, observation générale no 12(2009), Le droit de l'enfant d'etre entendu, no rr, P.^. 


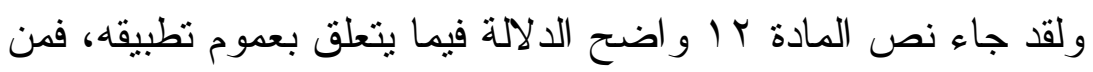

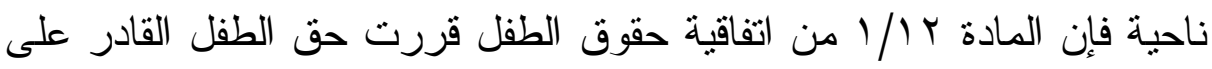

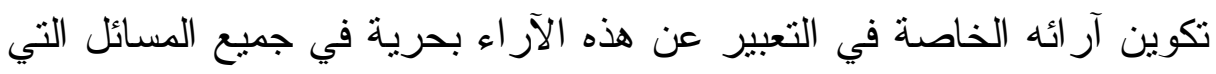

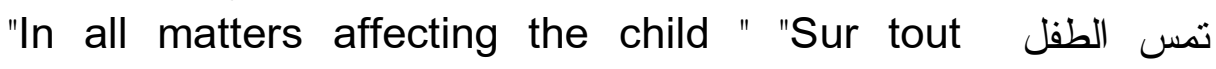
question l'interesent"

وفى هذا الصدد، لم تستجب مجموعة العمل التي كانت مكلفة بإعداد

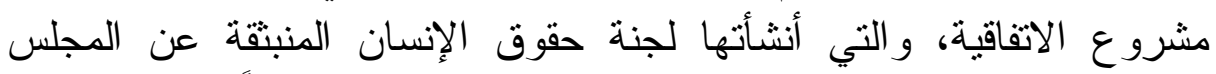

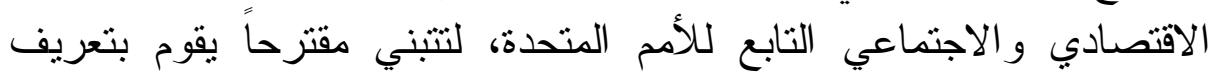

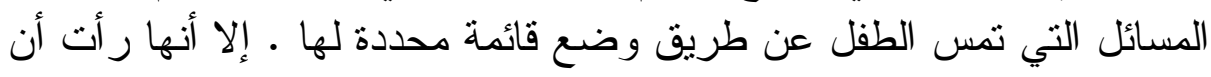

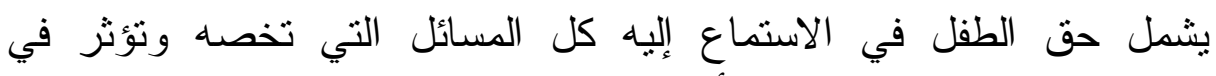
مصالحه، ودون الحاجة لوضع أحو ال محددة.

وأثتاء القمة العالمية الخاصة بالطفل، تبنت الدول المشاركة في هذه

القمة التفسير الواسع لعبارة " المسائل التي تتعلق بالطفل حيث ذلئ ذلك التفسير

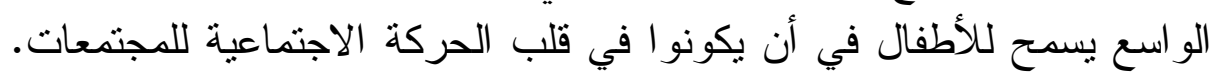

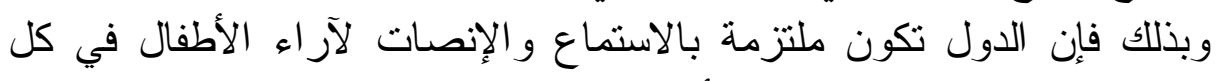

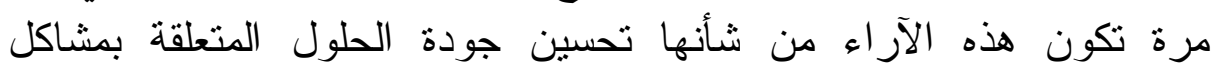
الأطفال.

و أضافت المعاهدة في الفقرة الأولى من المادة rا أنه يجب أن تؤخذ

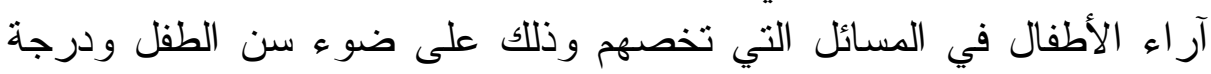

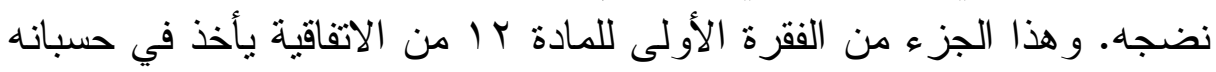

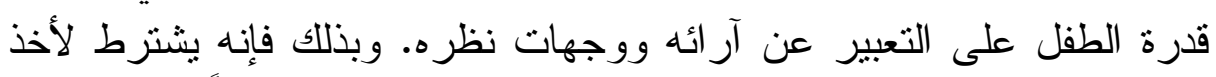

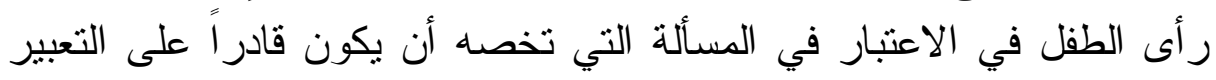

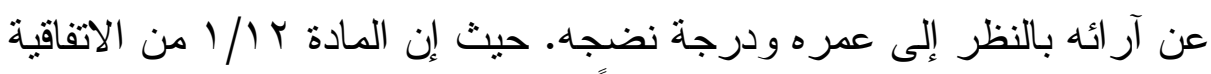

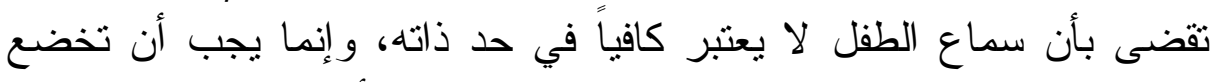

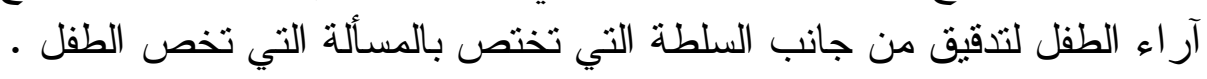

وفى هذا الصدد إذا كانت السلطات ملتزمة بأن نأخذ في الاعتبار آراء

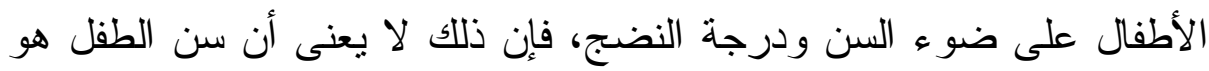

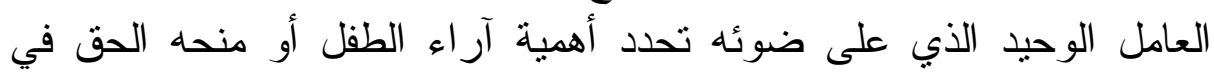


الاستماع إليه، حيث إن درجة فهم الطفل لا ترتبط تلقائياً بسن الطفل، إنما

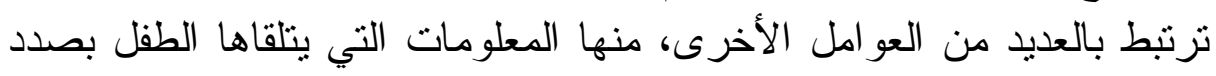

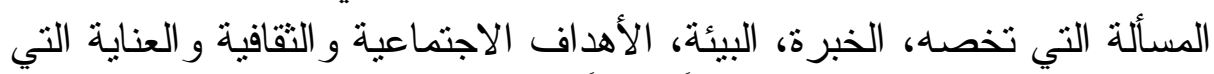

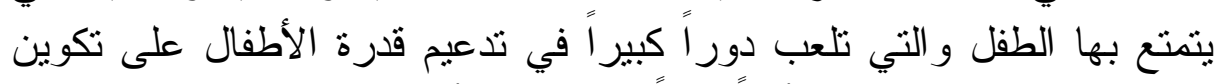

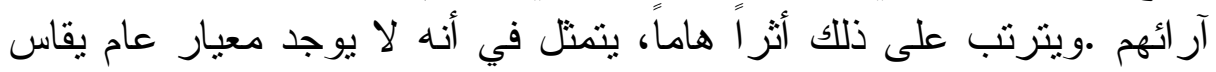

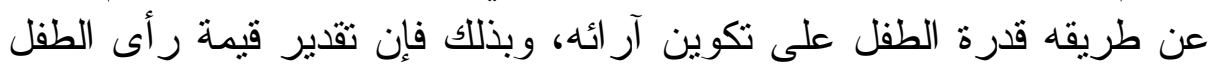

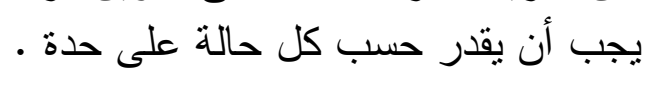

ودرجة النضج تعتمد على قدرة الطفل على الفهم وتقدير نتائج القرار الذي سيصدر في المسألة التي تخصده. وبذلك فإنها يجب أند أن تأخذ في الاعتبار

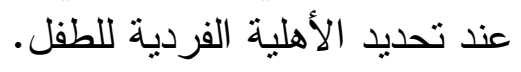

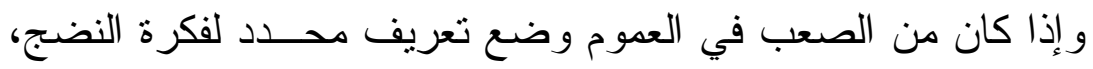

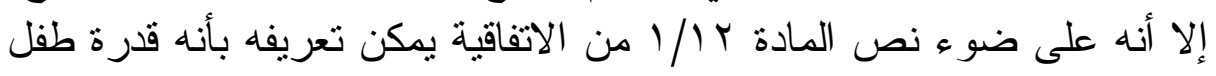

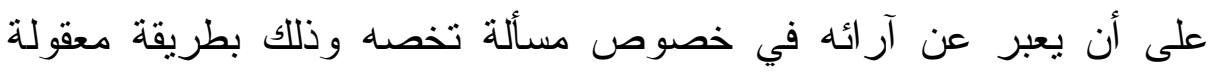

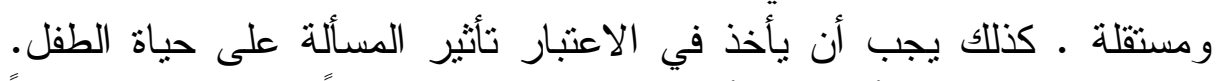

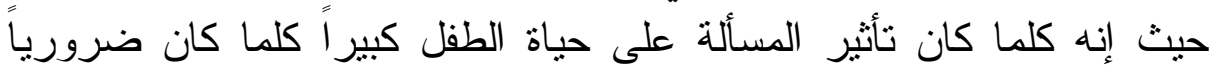

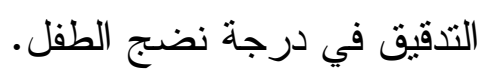

وبعد أن قررت الفقرة الأولى من المادة rا من الاتفاقية حق الطفل

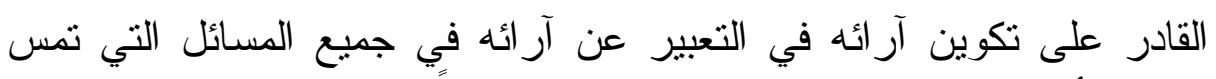

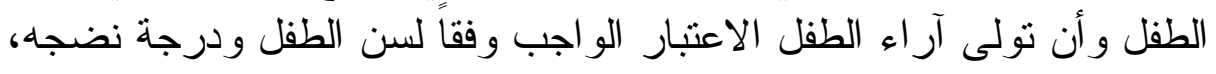

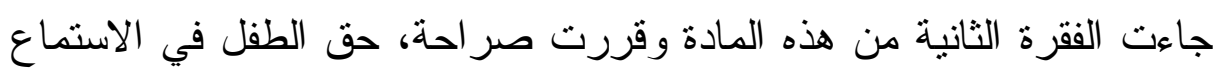

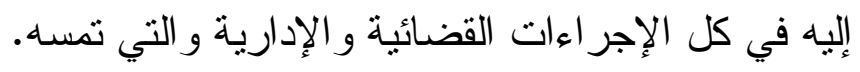

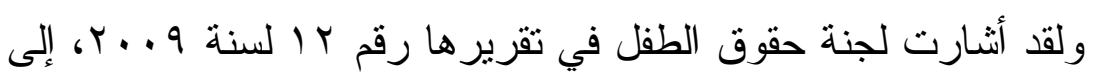

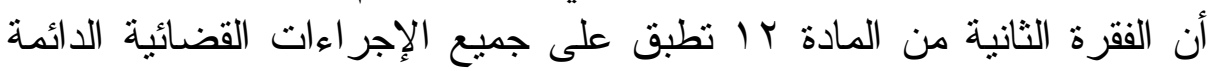

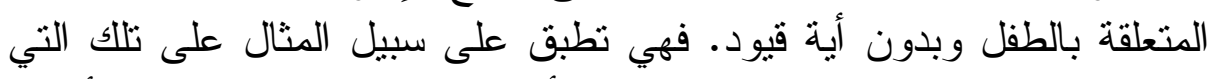

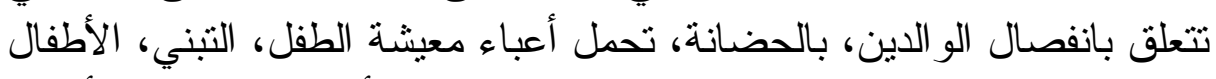

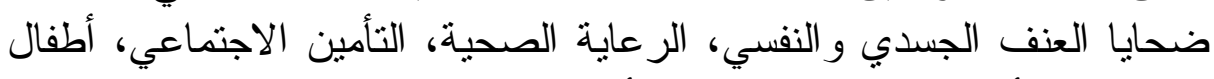

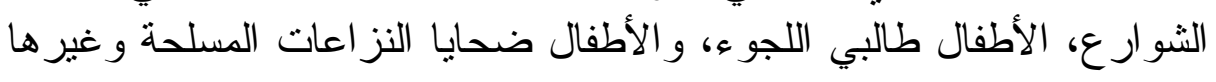


من المسائل التي تمس الطفل (').

و إذا كان هذا الحق يتعلق بالإجر اءات القضائية، فإنه أيضناً يتعلق

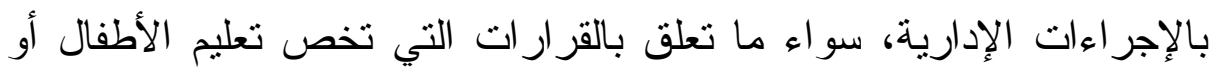

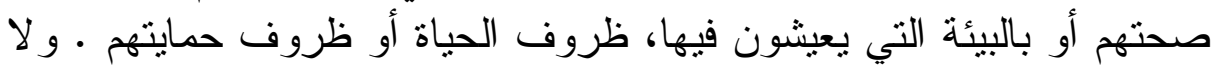
يقتصر حق الطفل في الاستماع إليه على الإجر اءات القضائية بالمعني الفني

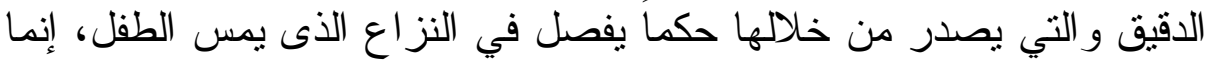
يكون هذا الحق في جميع طرق فض المنازعات الأخرى، منل الوساطة أو لون التحكيم.

ذلك أن نص المادة r// r/ جاء عاماً غير مقصور على العملية

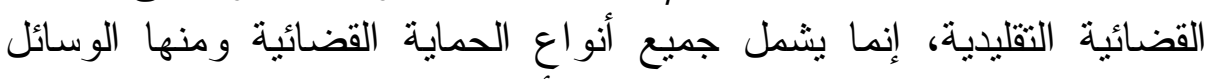
البديلة لفض المنازعات. فغاية المعاهدة أن لا يصدر قرار بتعلق بمصالح الطفل بدون أن بسمع رأيه أمام الجهات التي تختص بإصدار هذه القرار ات وتز اقب صدور ها.

وحق الطفل في الاستماع بنطبق سو اء كانت الإجر اءات قد بدأت بناء على طلب من الطفل أو بناء على طلب من غيره من الأشخاص وكانت هذه الإجراءات تتعلق وتمس مصالحه، منل الإجراءات التي تبدأ بناء على طلب

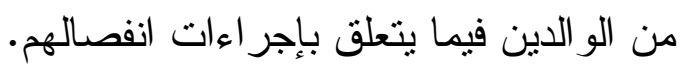

ثم بعد أن قررت الفقرة الثانية من المادة r ا من اتفاقية حقوق الطفل حق الطفل في أن بستمع إلبه في جميع الإجراءات القضائية و الإدارية التي تمسه، جاءت و أثنارت إلى آلبة سماع الطفل، وقررت أنه يجوز سماع الطفل

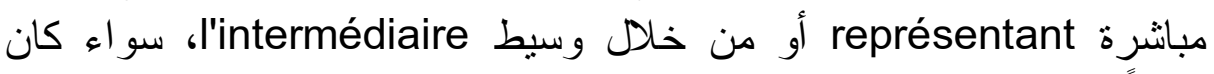

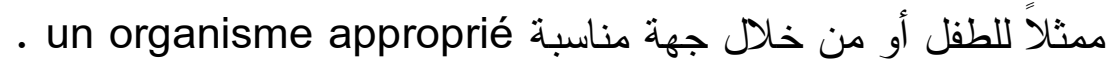
وفى هذا الصدد أوصت لجنة حقوق الطفل التابعة للأمم المتحدة بأن يمنح الطفل - في كل مرة يكون ذلك ممكنا - إمكانية أن يستمع إلبه مباشرة أياً كانت الإجراءات التي تمس الطفل. وبذلك فلقد أر ادت اللجنة أن تعطى دهى دهن الأولوية لسماع الطفل مباشرة بدون وسيط أياً كانت صفته. وممثل الطفل يمكن

(1) Comité des droits de l'enfant, cinquante et unième session, Genève 25 mai 12 Juin 2009, observation générale no 12(2009), Le droit de l'enfant d'etre entendu, no 32, P.10. 


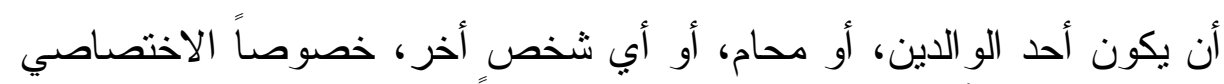

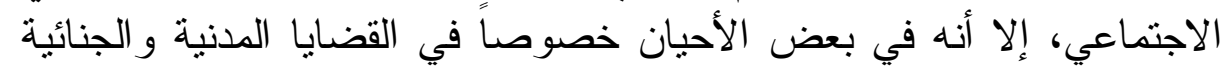

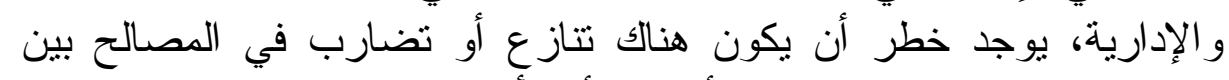

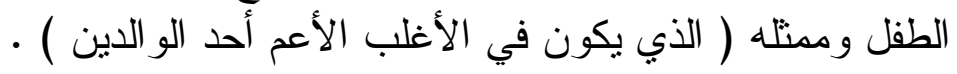

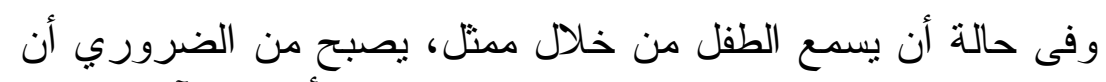
تضمن الإجراءات التي تتظم حق الطفل في الاستماع إليه أن تتقل آن آراء الطفل

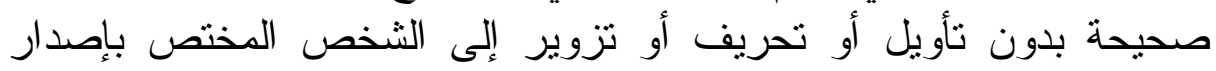

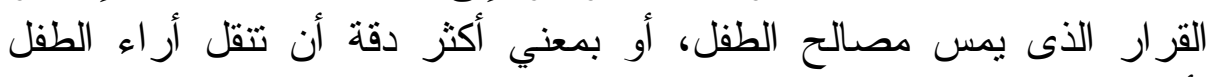
بأمانة بو اسطة المثنل

كذلك يصبح من الضروري أن يكون الثخص الذى يتلقى آراء الطفل

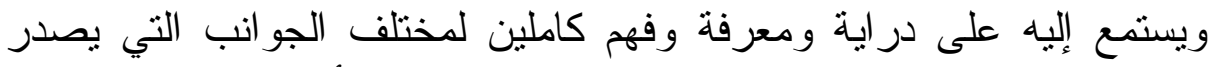

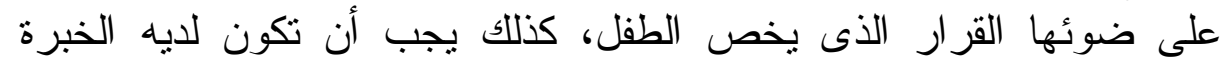

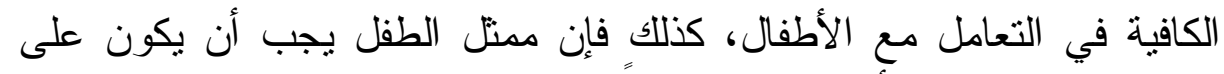

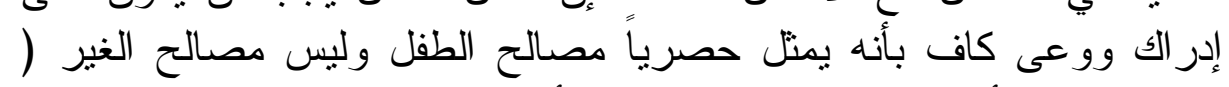

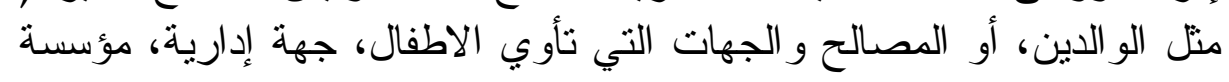

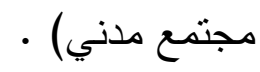

وأخير اً قررت الفقرة الثانية من المادة rا من الاتفاقية أن حق الطفل

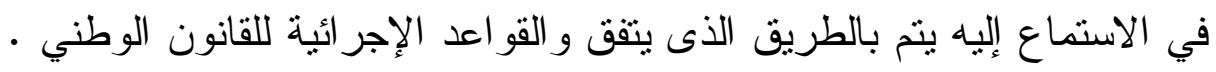

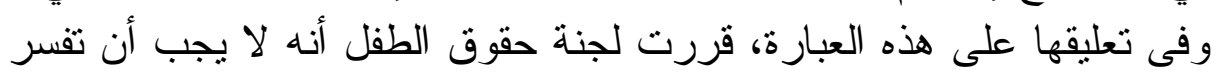

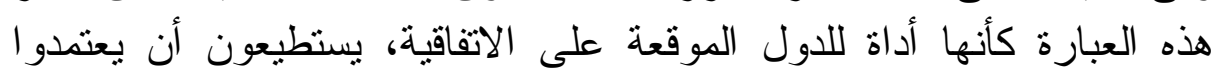

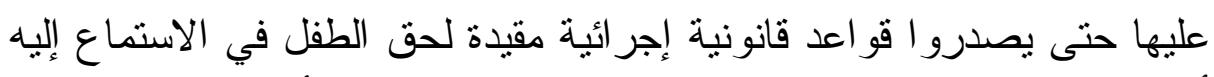
أو إصدار قو اعد قانونية إجر ائية تمنع ممارسة هذانية إجرائ الحق الأساسي.

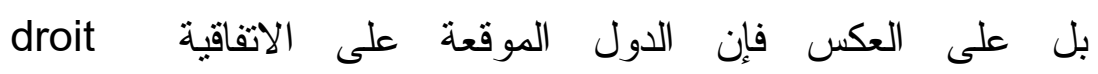

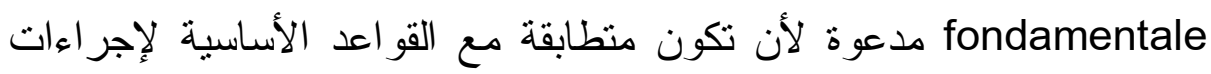
منصفة و عادلة منل حق الدفاع وحق الاطلاع على الملفات وأور اق التحقيقات.

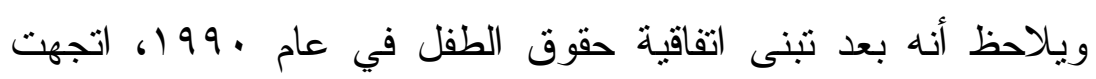

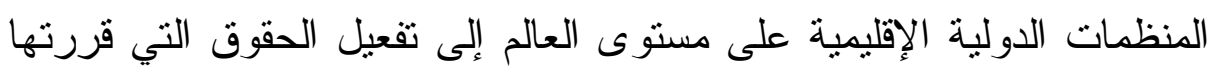

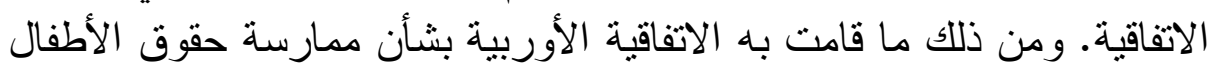

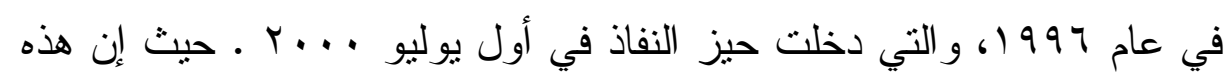


الاتفاقية تطبق على الأطفال الذين لم يتجاوزوا سن الثمانية عشر عاما.

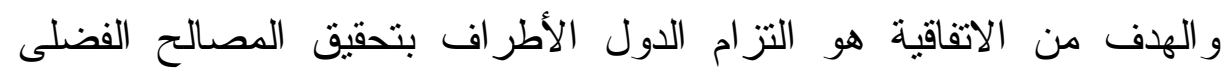

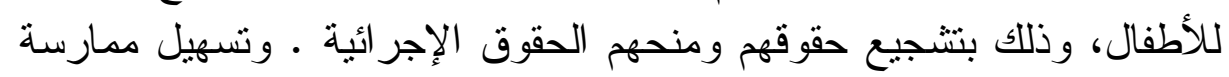

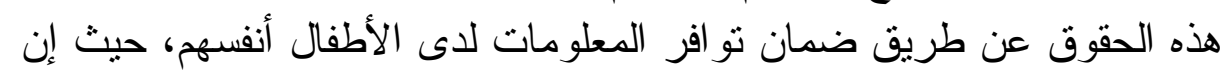

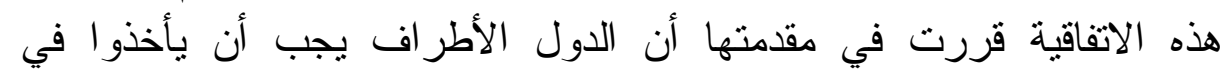
الاعتبار إنفاذ جميع الإجراءات التي تضمن فماية الحقوق و المصالح العليا

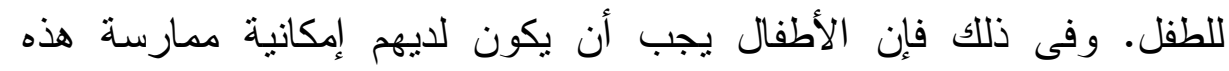

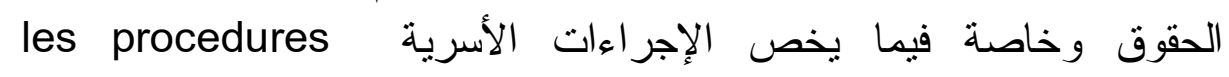
• التي تمسهر

كما أن أطراف الاتفاقية يعترفون بأن الأطفال يجب أن يتلقوا

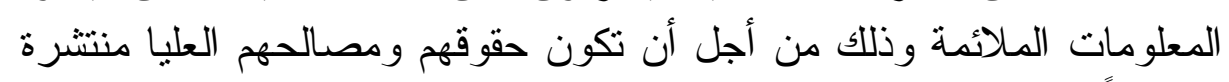

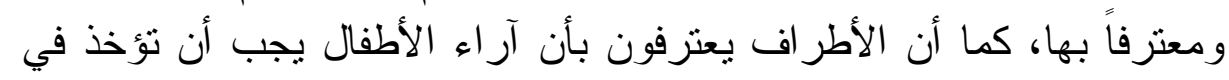

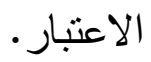

وفيما يخص حق الطفل في الاستماع إليه، جاءت المادة الثالثة من هذه الاتفاقية وقررت حق الطفل في إعلامه وفى التعبير عن رأيه في الإجراءات التهاء القضائية التي تتعلق به droit d'etre informé et d'exprimer son opinion dans les procedures le concerne

$$
\text { الفرع الثاني }
$$

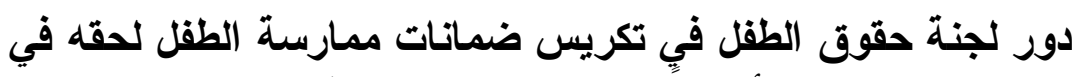

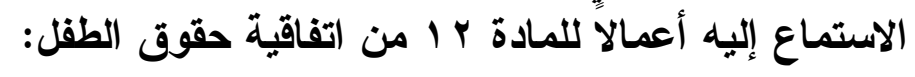

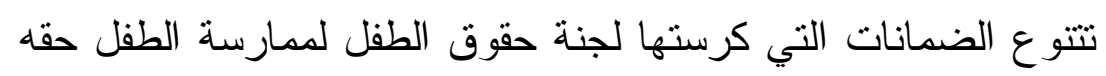

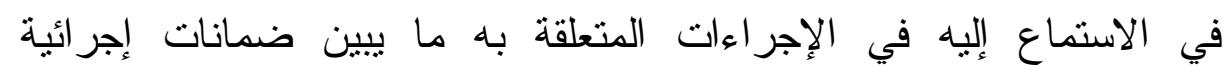
وضمانات موضو عية.

أ. الضمانات الإجرائية لممارسة الطقل لحق الاستماع إليه في الإجراعات المتعلقة به : الإجنات

رغم خلو اتفاقية حقوق الطفل من القواعد الإجرائية التي تحكم تطبيق

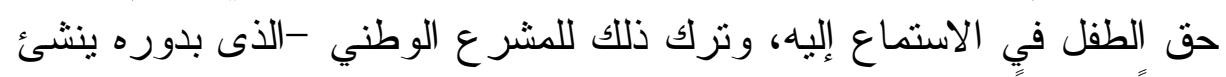

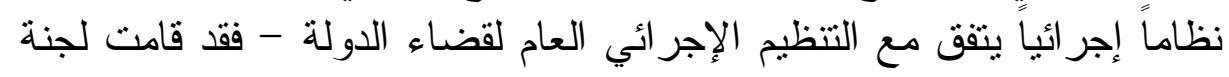


حقوق الطفل بإصدار توجيهات وتوصيات تمثل الحد الأدنى للتنظيم الإجرائي

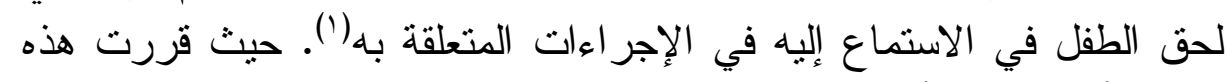

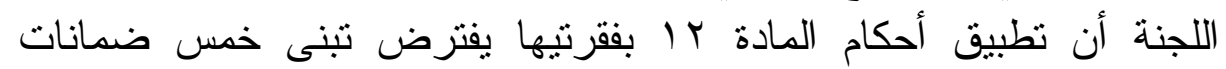

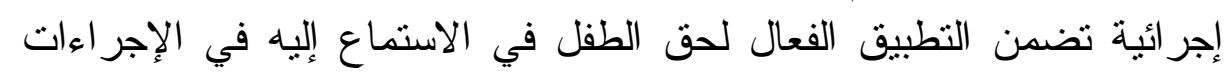
التي تمسـه.

\section{الضمانة الأولى: إعداد الطقل للاستماع إليه :}

علي الثخص المختص بسماع الطفل أن يتأكد من أن الطفل قد تِ إعلامده

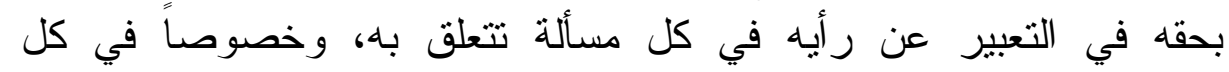
إجر اءات قضائية أو إدارية، كذلك يجب أبه أن يتأكد من إعلام الطفل بالنتائج

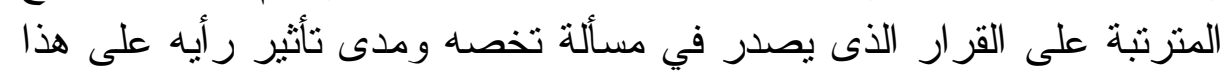

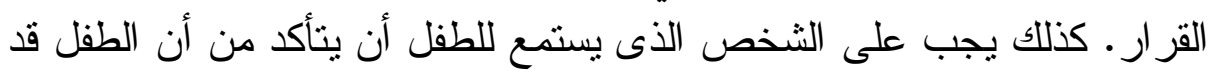
تم إعلامه بأن له الحق في أن يستمع إليه مباشرة أو من خلأل لأل ممثل.

ومن متطلبات إعداد الطفل للاستماع إليه أن يقوم الشخص المختص

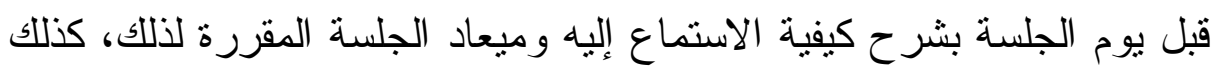

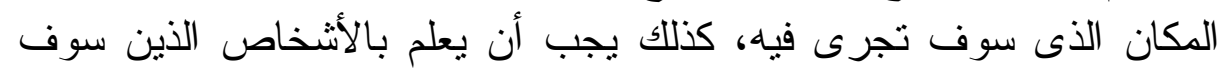
يشتركون في هذه الجلسة.

الضمانة الثانية : الاستماع للطقل بواسطة شخص مؤهل وفي ظروف ملأممة:

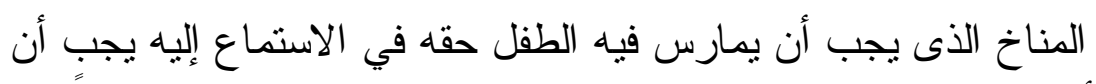

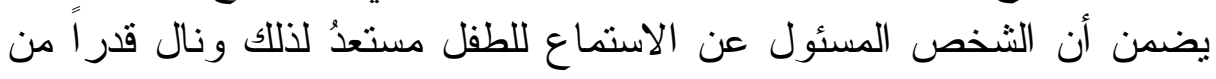
التدريب الجيد على هذه المهمة .

كذلك فإن عملية الاستماع للطفل يجب أن تأخذ شكل مقابلة entertain

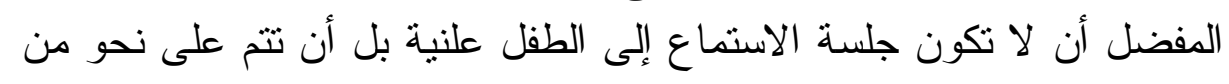

(1) Comité des droits de l'enfant .... no 40 ets, P. 11, 12. 
الضمانة الثالثة : تقدير قدرة الطقل :

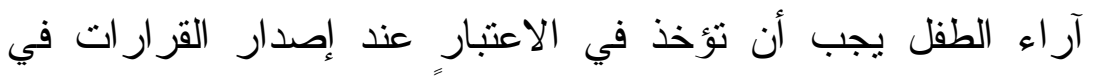

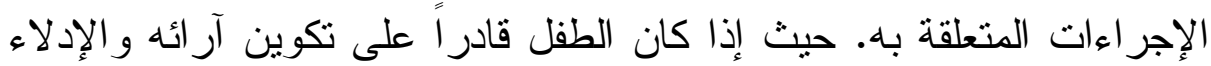

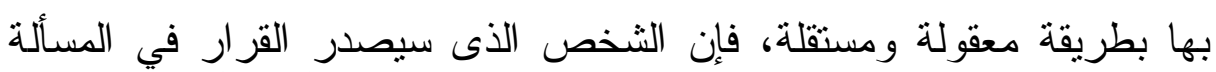

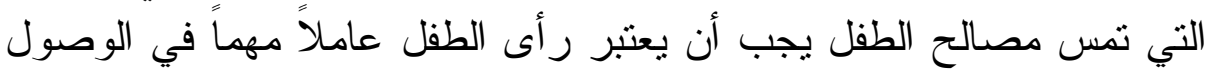
إلى حل لهذه المسألة المعروضة عليه.

الضمانة الرابعة : إعلام الطقل بقيمة رأيه :

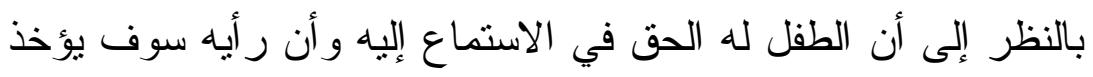

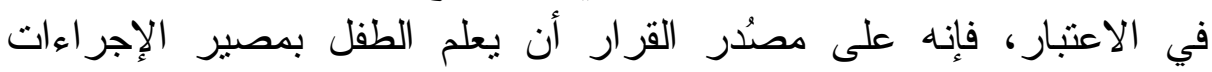

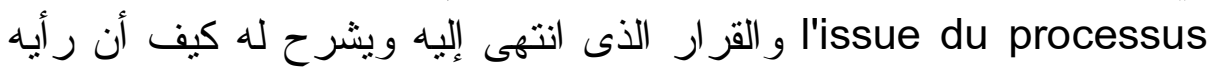
الذى أدلى به أخذ في الاعتبار عند إصدار القرار في المسألة التي تمس له الته

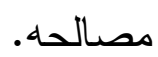

و لا شك أن هذا الإجراء يضمن أن لا يكون رأى الطفل والاستماع

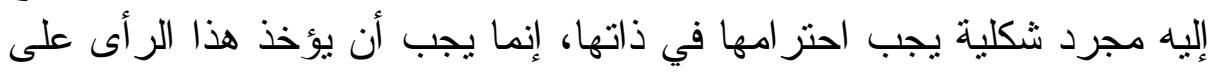

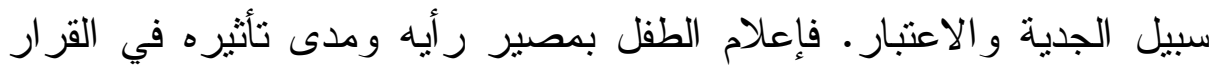

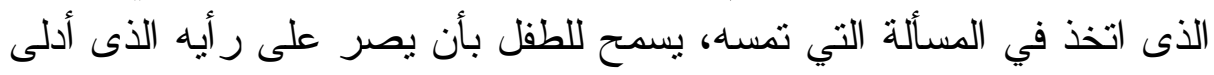

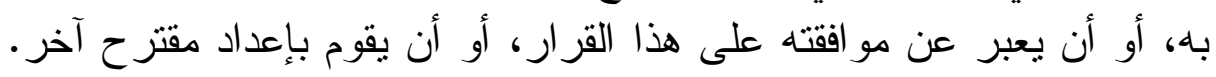

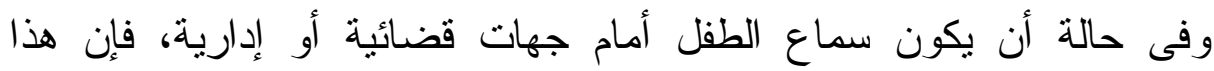

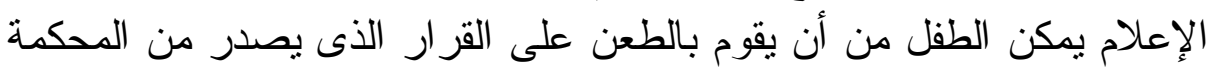
أو أن يقدم شكوى ضد قر ار جهة الإدارة.

الضمانة الخامسة : الحق في الثكوى، الطعن والتعويض :

من أهم الضمانات التي قررتها لجنة حقوق الطفل ضمانة أن تكون

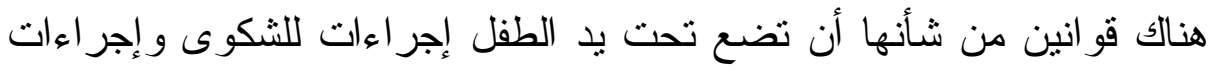

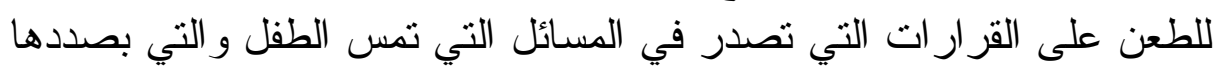
قد مارس الطفل حقه في الاستماع إليه، وذلك عندما يكون حقه في الاستماع

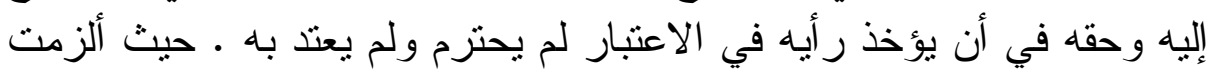


اللجنة الدول الأطر اف بأن تصدر قو انين وطنية بشأن حق الطفل في الثكوى

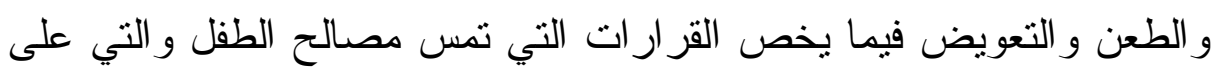
إثرها قد مارس الطفل حقه في الاستماع إليه .

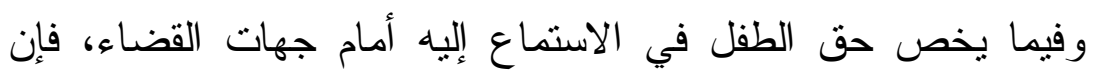

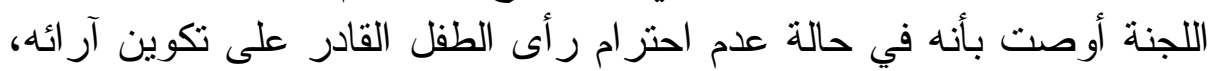

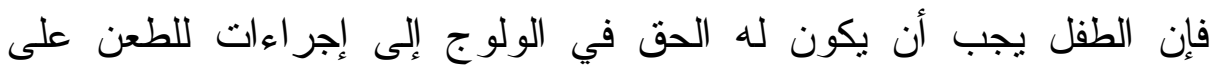

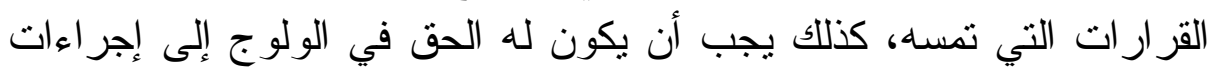

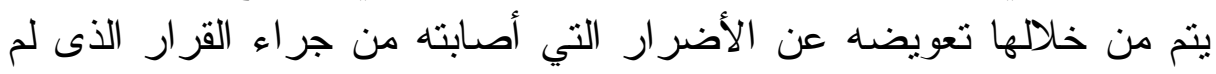

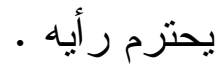

هذه الإجراءات يجب أن تعتمد على آليات موثوق فيها تضمن للطفل بأن يستعطها ويمارسها بدون خشية أن تكون هنالك عقوبات أو أعمال تعنيفيه . ب.- الضمانات الموضوعية لحق الطقل في الاستماع إليه في الإجراعات

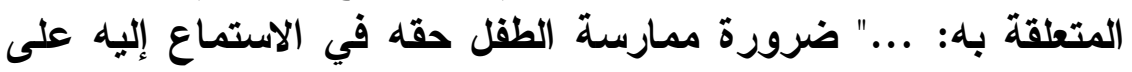
ضوء بعض المبادئ العامة لاتفاقية حقوق الطقل

يرتبط حق الطفل في الاستماع لآر ائه في المسائل التي تمسه و الذى الذى

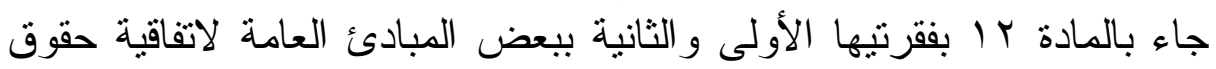

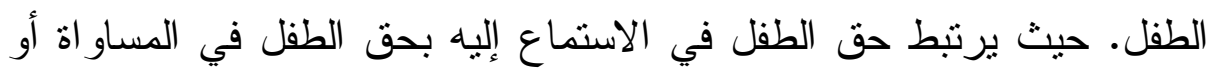

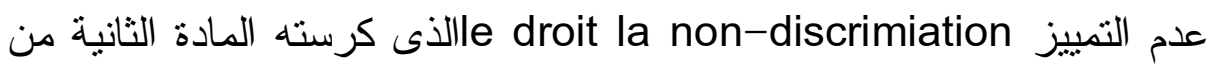
الاتقاقية.

ويرتبط أيضاً حق الطفل في الاستماع إليه بحق الطفل في أن تكون

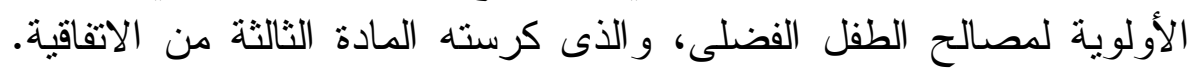
ويرنبط حق الطفل في الاستماع إليه بحق الطفل في التعبير عن آرائه وحقه الإنه

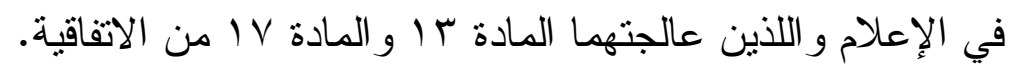

الضمانة الأولي : حق الطقل في الاستماع إليه على ضوء الحق في المساواة " أو الحق في عدم الطميز في الاسنياع اله ":

مبدأ المساو اة التامة أو عدم التمييز تثبته العديد من المواثيق الدولية

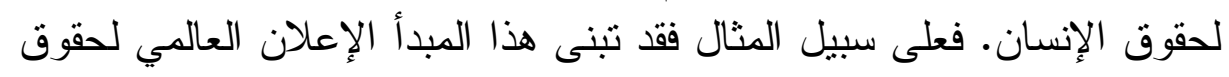




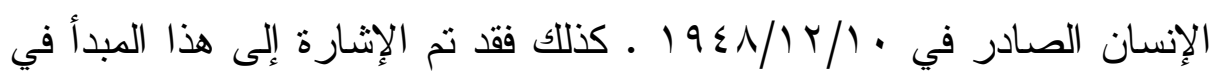
إعلان حقوق الطفل الصادر في 1909 1، وكذلك المادة الثانية من العهدين العان العادين الدوليين الصادرين عام 1977 للحقوق المدنية و السياسية و الحقوق الاقتصادية

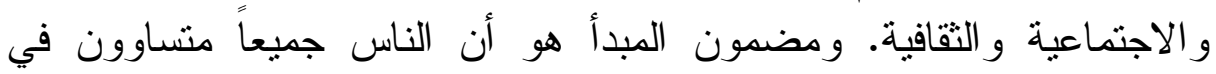

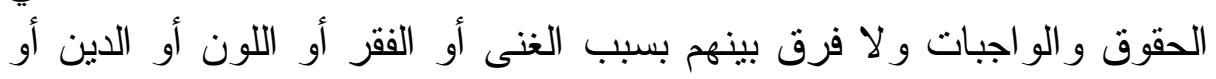

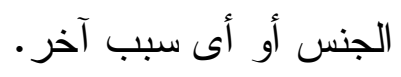

وتطبيقاً لذلك فقد نصت المادة r/ 1 من اتفاقية حقوق الطفل على إنه

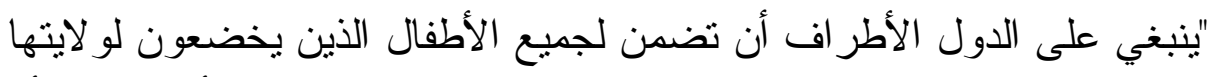

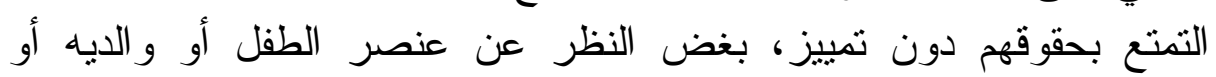

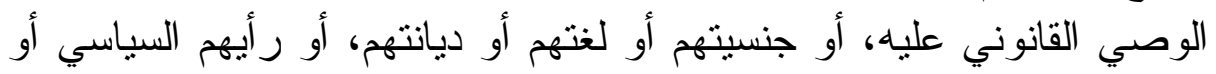

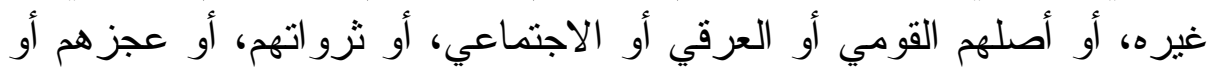

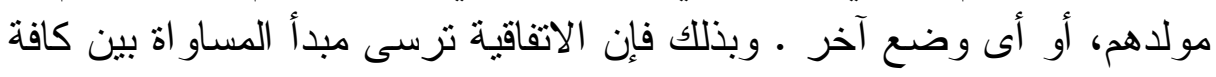

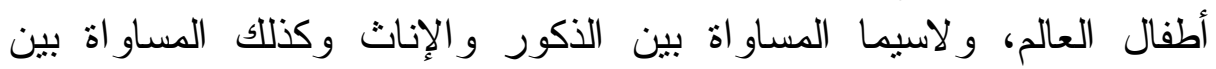

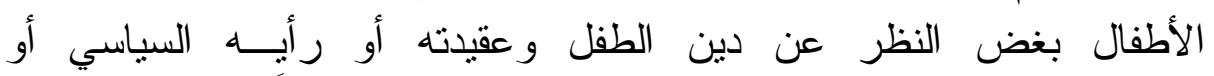

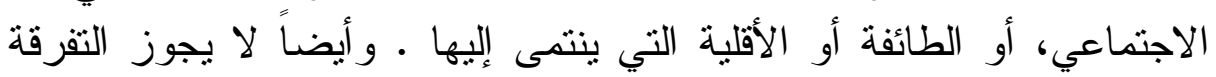

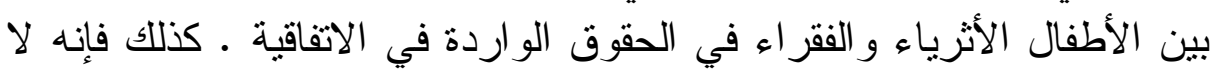

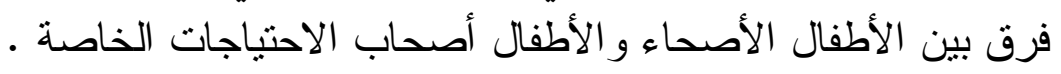

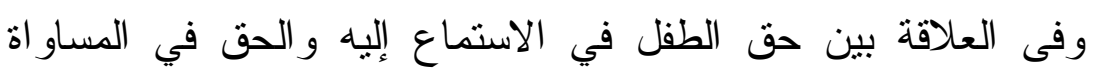

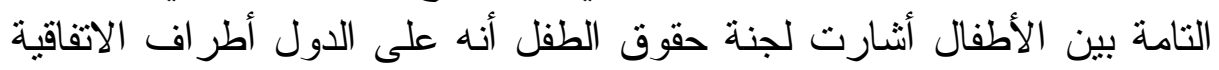

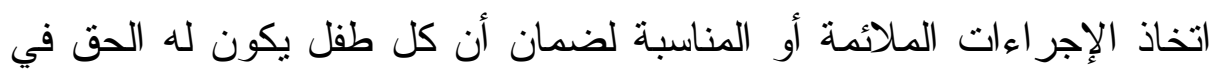

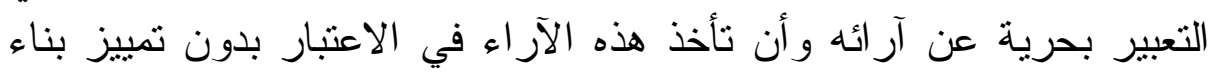

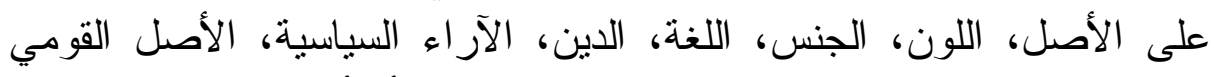

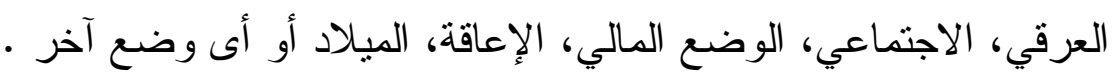

كذلك فإن الدول الأطر اف يجب أن تكافح ضد التمييز، و لاسيما ذلك

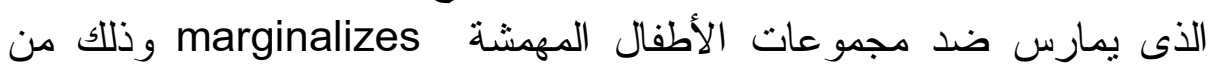
أجل أن يستطيع هؤلاء الأطفال أن يمارسو الحقهم في الاستماع لهم وأن يكون

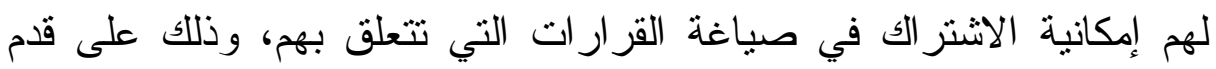

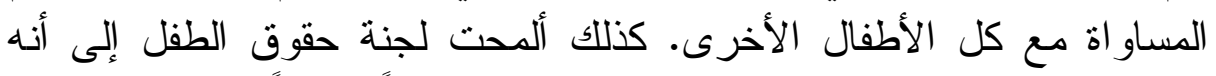

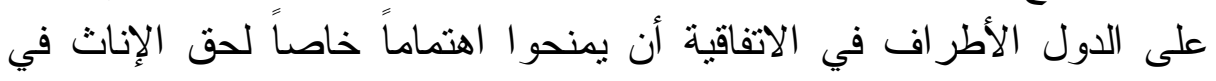


الاستماع لهم، وأن يساعدوا في الإدلاء بآرائهم وأن تأخذ هذه الآراء في الحسبان. انماع

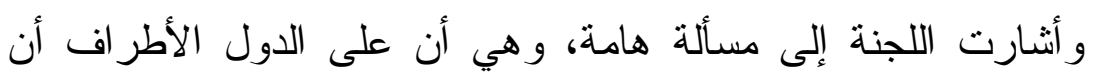

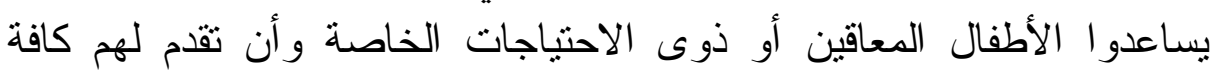

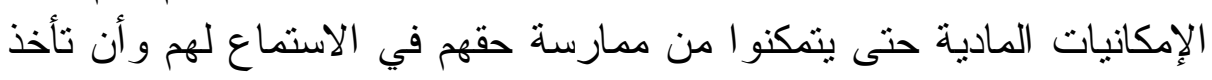

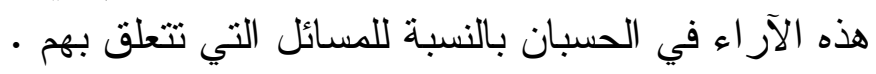

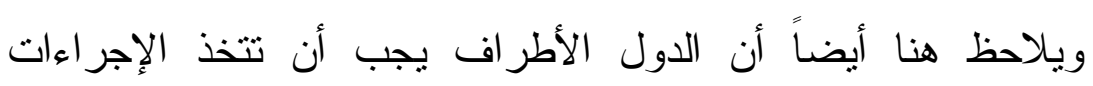

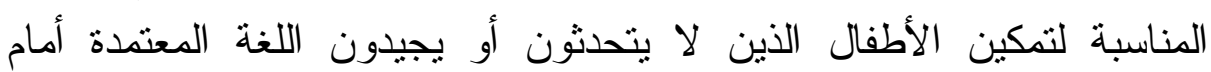

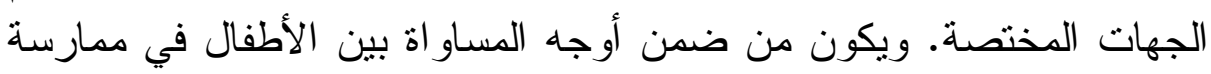

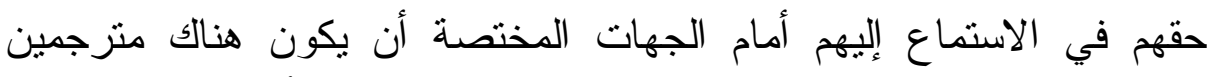

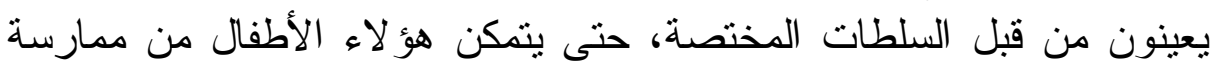
هذا الحق، و لا تعوق لغة الطفل بينه وبين حقه في الاستماع إليه.

ومن هنا يتضح أن العلاقة وطيدة بين حق الطفل في الاستماع إليه

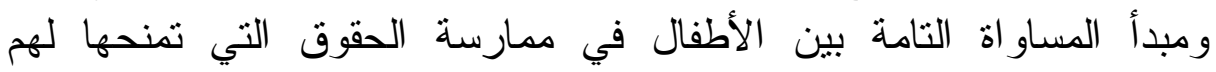
الاتفاقية.

وأن مبدأ المساو اة بين الأطفال يمنل ضمانة هامة في حسن ممارسة

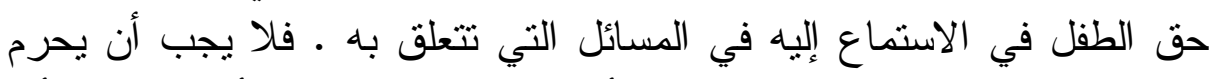

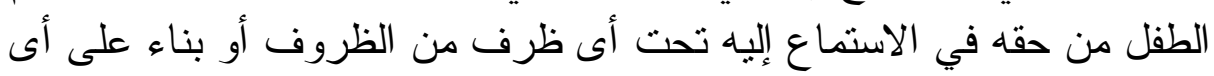

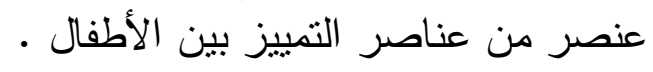

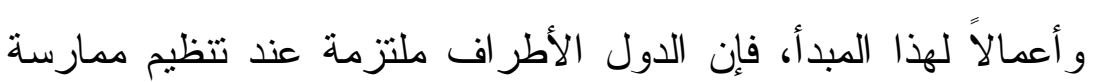

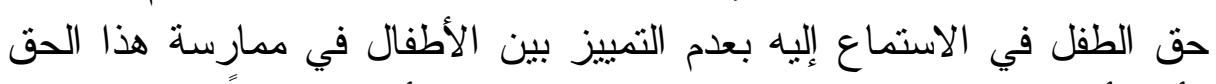

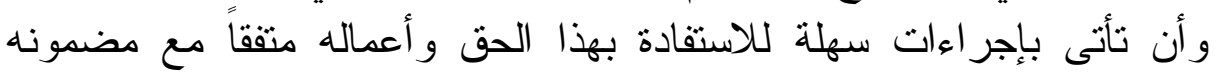
و وهدفه الحقيقيين.

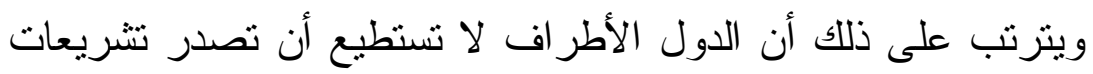

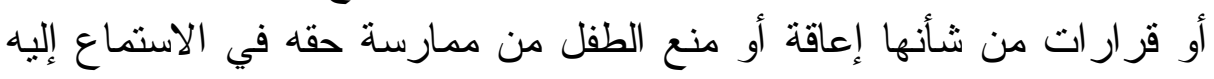

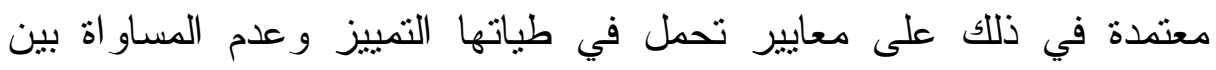


وبذلك فإن المادة / / من اتفاقية حقوق الطفل تمثل ضابطاً هاماً في

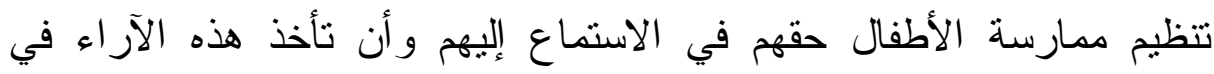

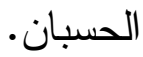

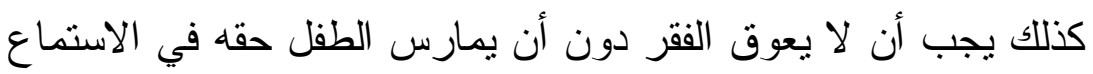

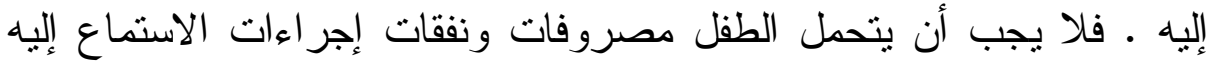

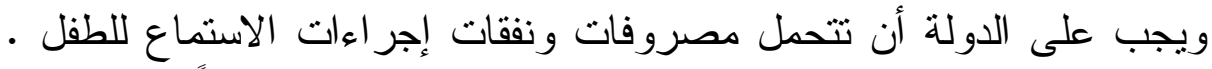

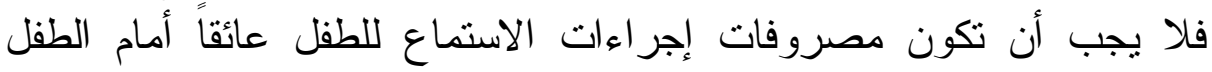

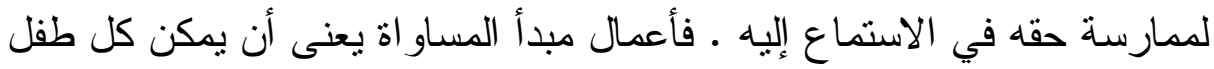

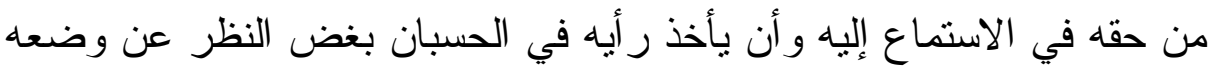

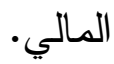

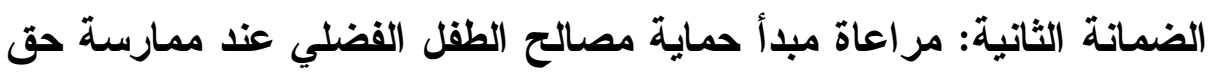
الطفل في الاستماع إليه في الإجراءات المتعلقة به:

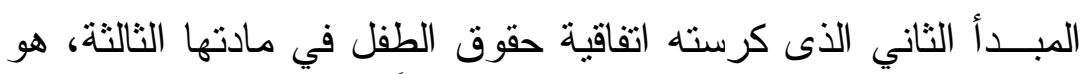

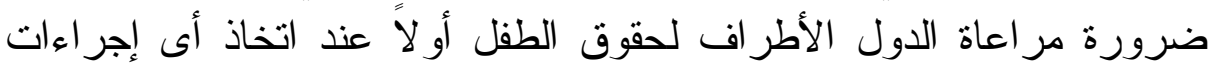

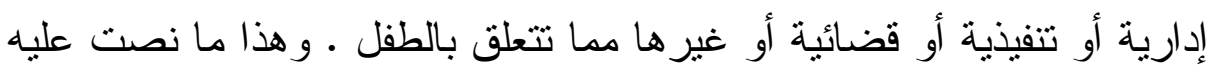

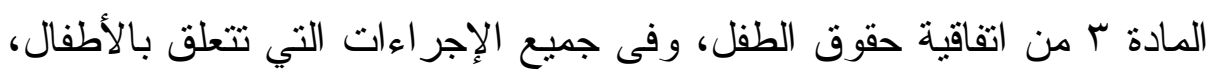

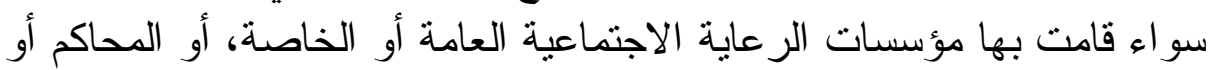

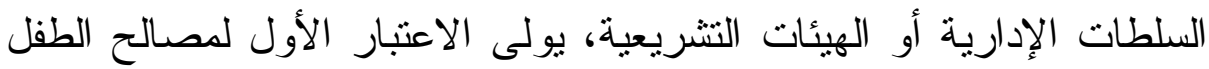

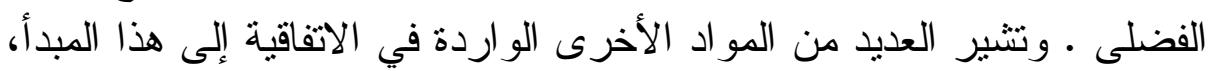

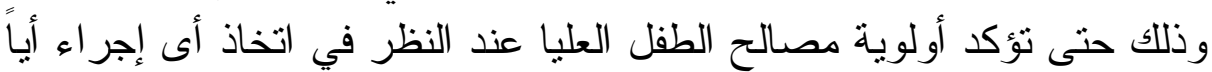

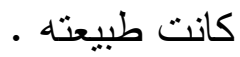

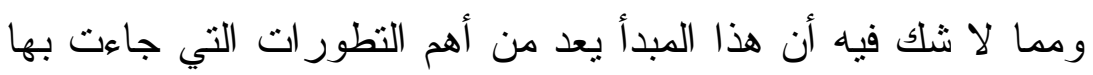

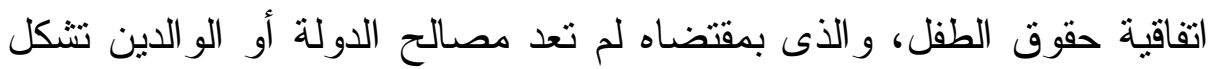

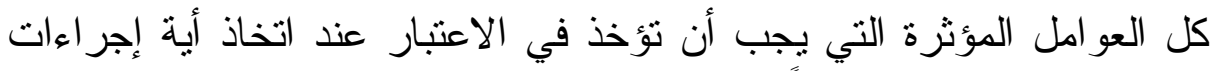

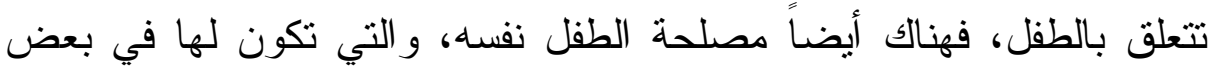




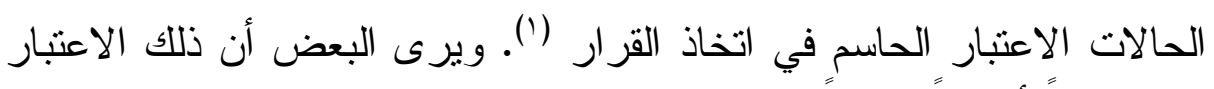

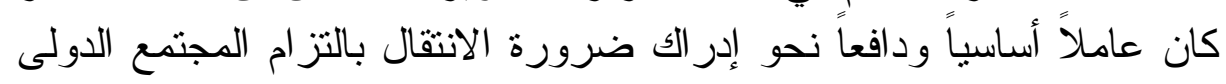

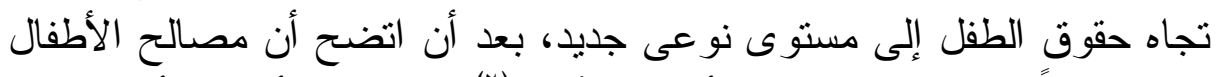

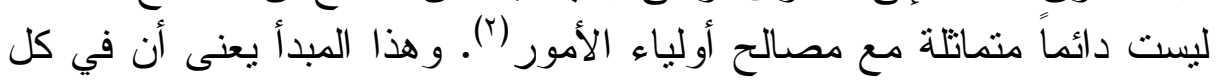
قر ار يتخذ باسم الطفل يجب أن تحترم مصالحه العليا المتعلقة بـه.

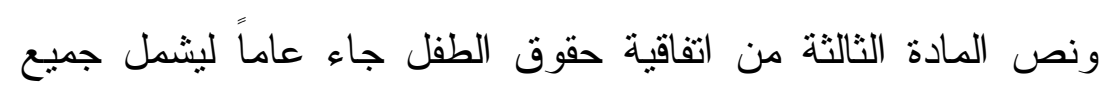

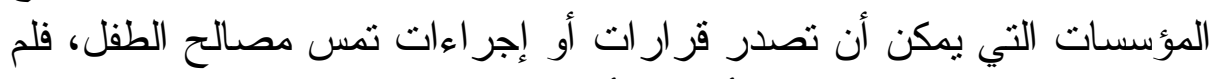

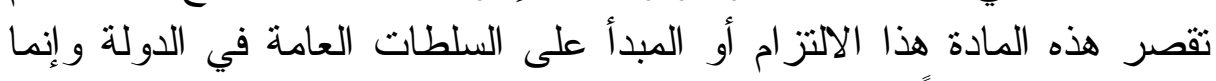

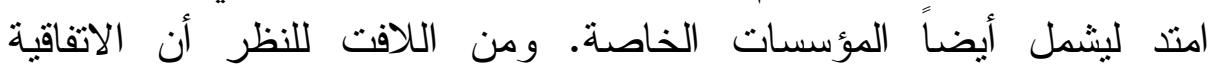

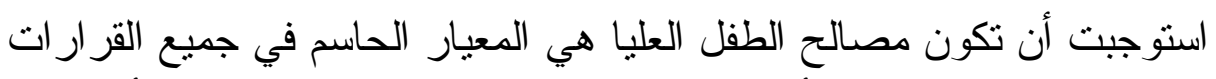

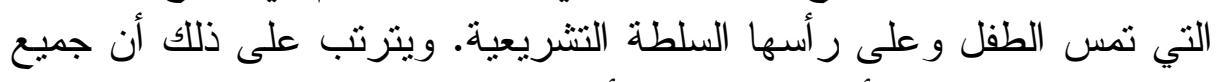

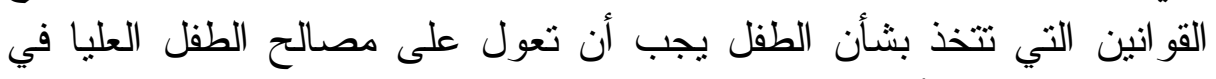

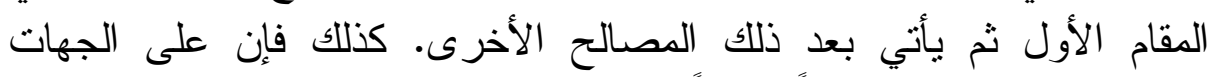

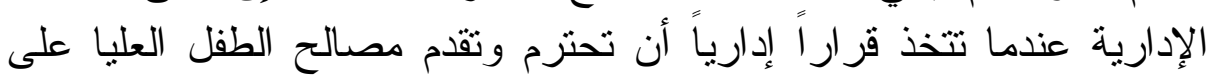

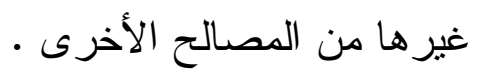

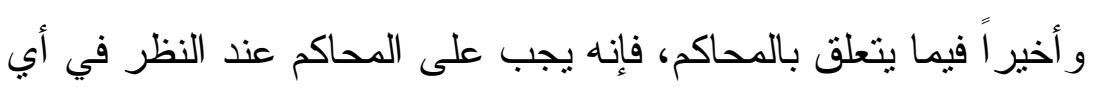

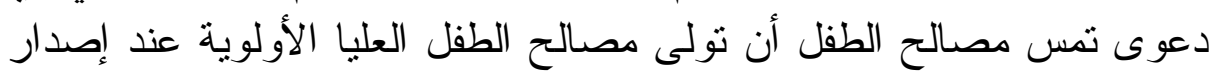

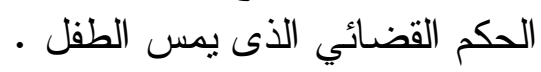

وقد قررت لجنة حقوق الطفل في تقريرها رقم r ا لسنة و . . ب أنه لا

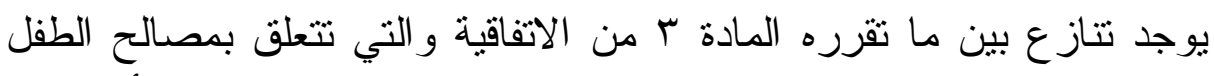

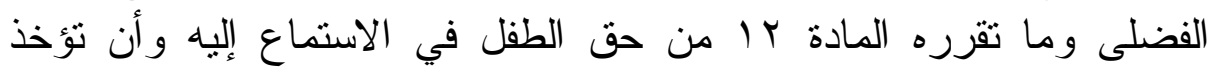

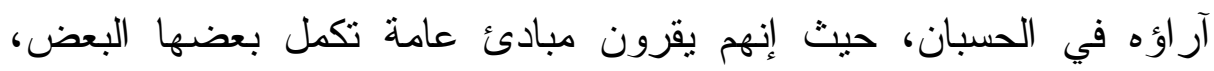

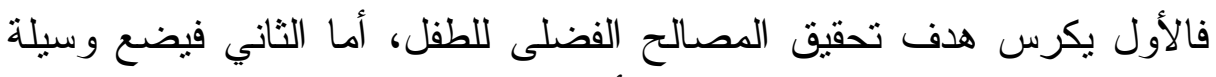
الوصول إلى هذا الهدف، فلا شك أن الاستماع للطفل سيمكن من تحقيق

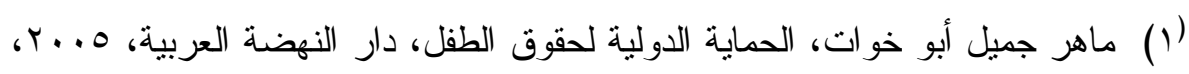
ص صاهر حميل

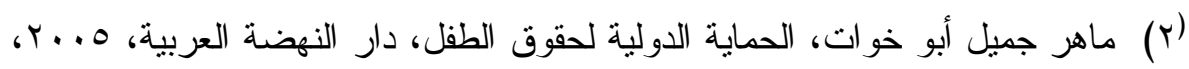

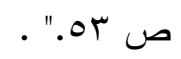


مصالح الطفل الفضلي.

وبذلك فإن تحقيق المصالح الفضلى للطفل لا يمكن تطبيقها تطبيقاً

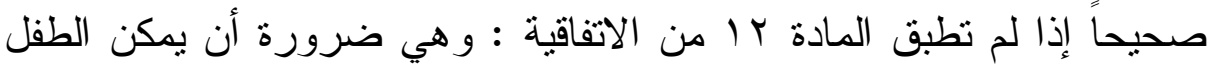

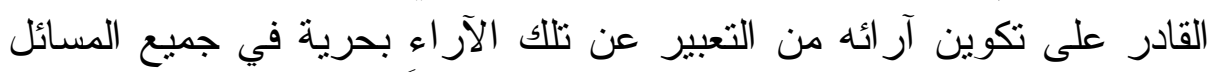

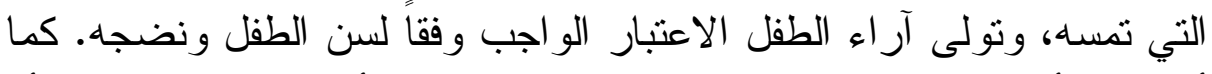

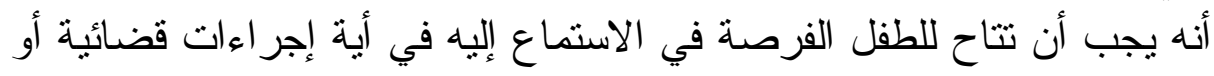

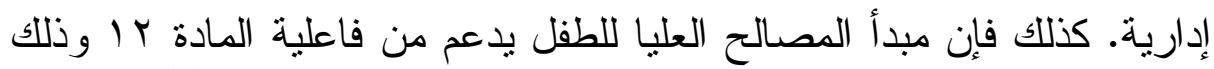
بأن يسهل الدور الرئيسى للأطفال في القرار الت التي التئ لمس حياتهم ('). الضمانة الثالثة : حق الطقل في الاستماع إليه بكل حرية والحق في الحصول

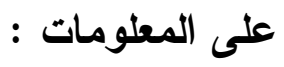

طبقاً للمادة سا من اتفاقية حقوق الطفل يكون للطفل الحق في حرية التعبير، ويشمل هذا الحق حرية طلب جميع المعلومات و الأفكار وتلقيها

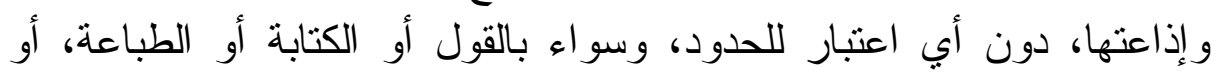

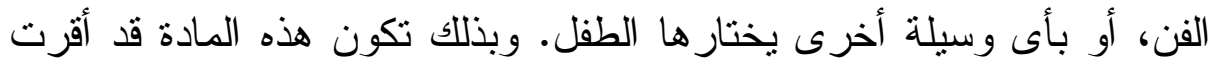
حق الطفل في التعبير بأى وسيلة يختار ها الطفل.

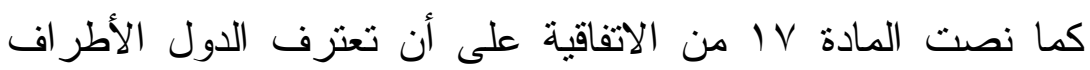

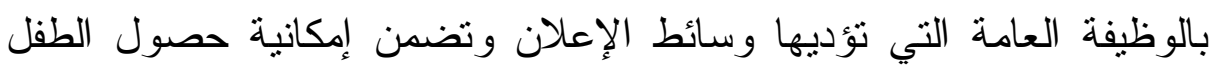

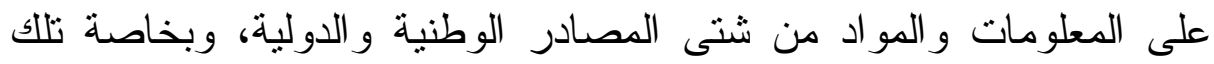

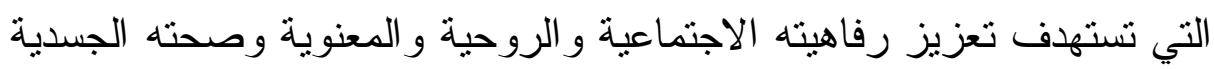
و العقلية .

وفى تعليقها على العلاقة بين أحكام المادة با ا و المادة با من اتفاقية

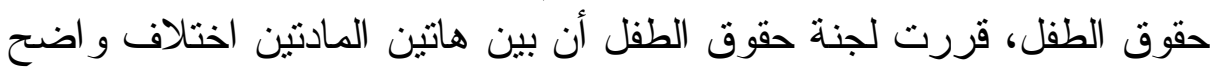

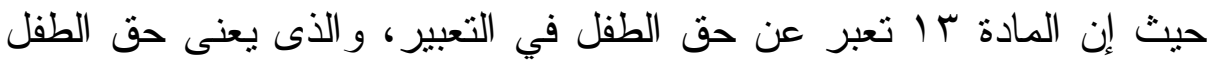

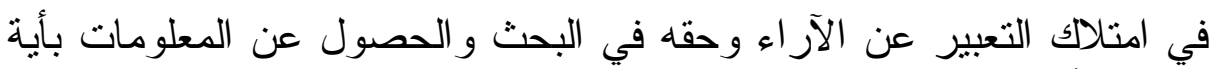

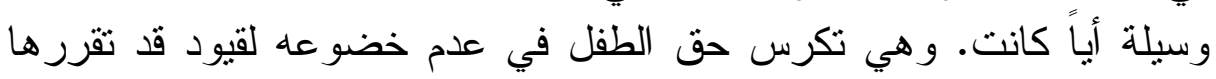

(1) Comité des droits de l'enfant, le droit de l'enfant être entendu. No 73, P. 16. 
الدول الأطراف في الاتفاقية فيما بتعلق بالإدلاء بآرائه أو التعبير عنها.

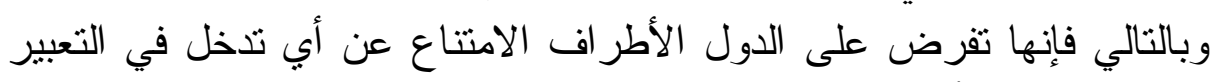

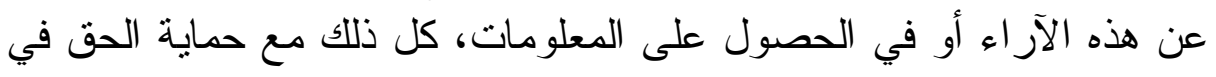

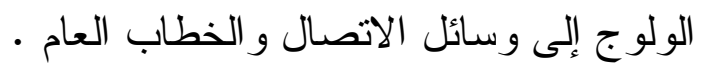

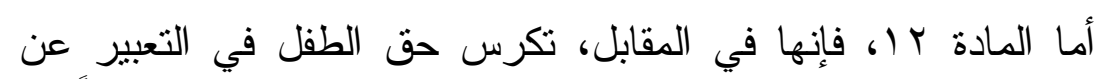

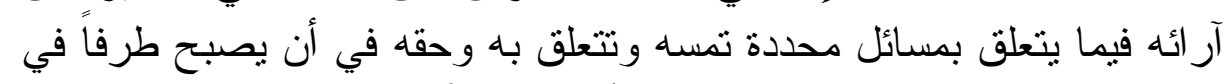

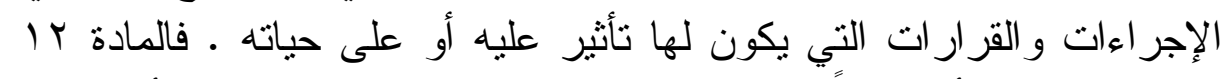

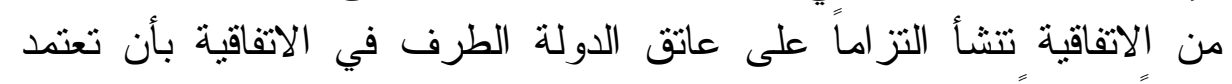

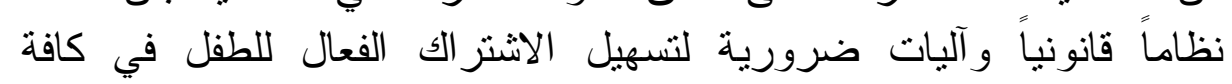

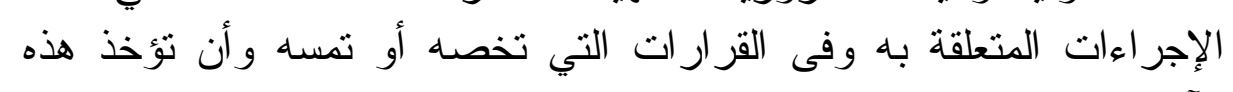

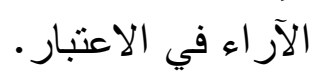

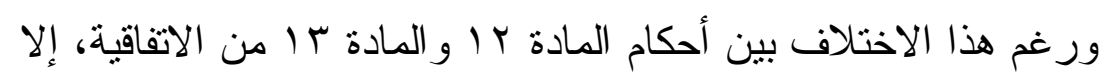

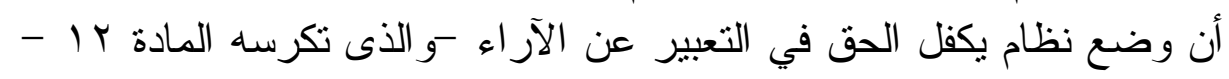

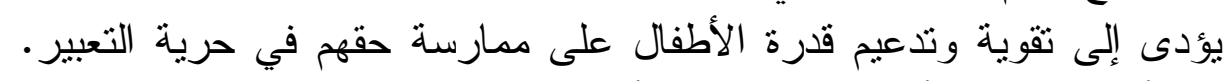

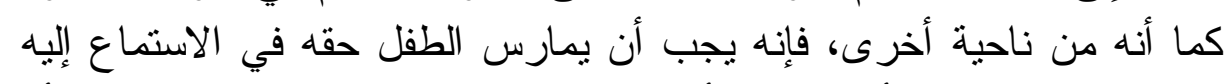

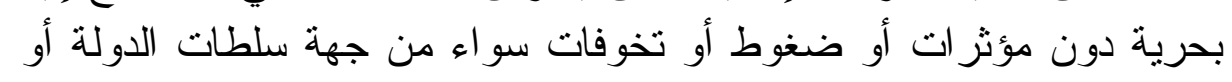

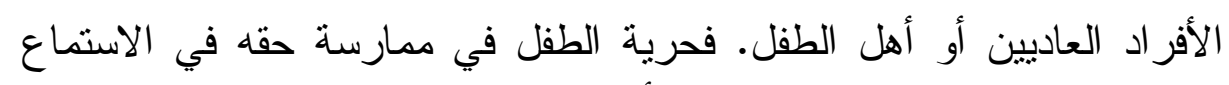

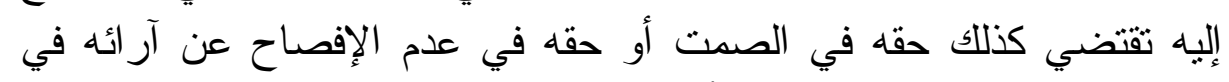

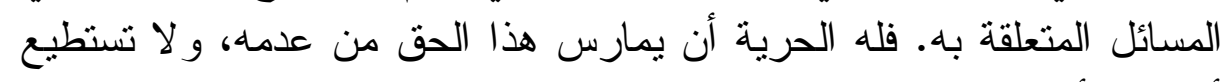

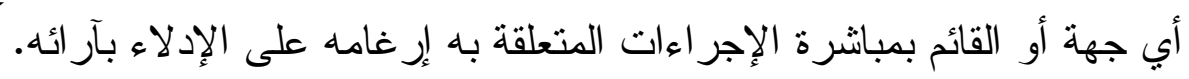

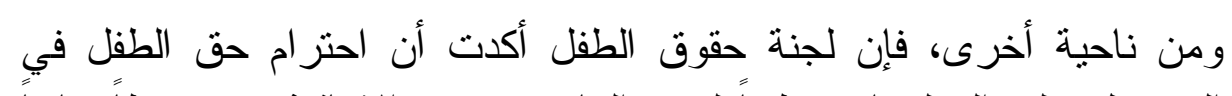

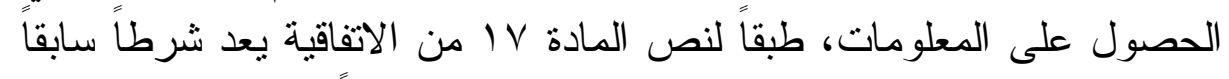

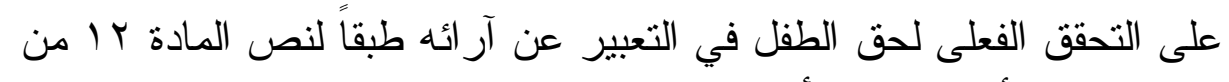

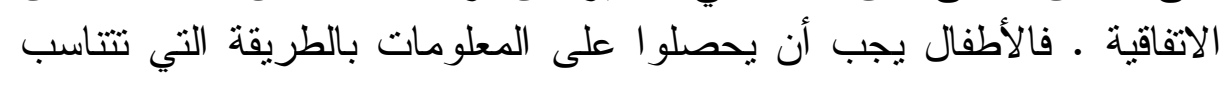

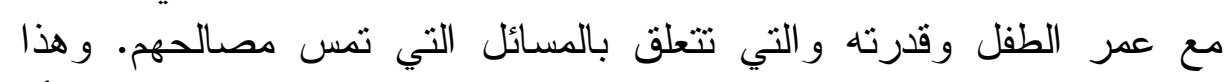

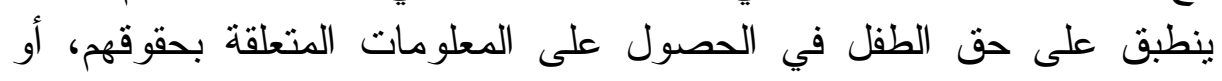

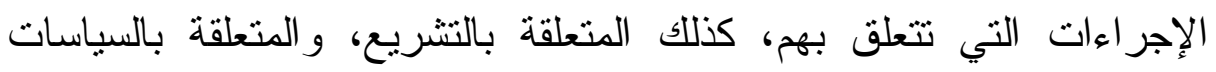

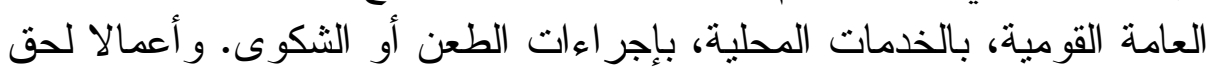

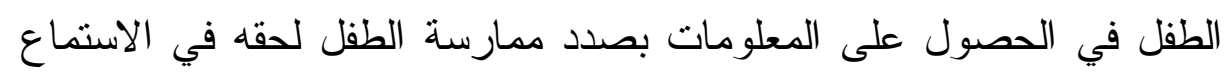


اليه، فإنه يجب إعلام الطفل بحقه في الاستماع اليه في الإجراءات المتعلقة

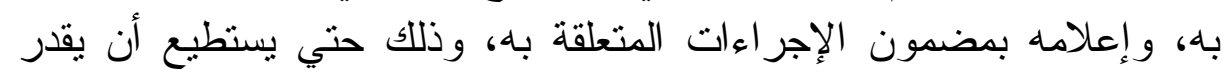

$$
\text { مباشرة حقه في الاستماع إليه من عدمه الإهـ اعنه }
$$

كذلك حتي يستطيع أن يعبر عن أرائه في خصوص موضوع الإجراءات

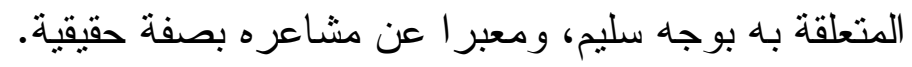

$$
\text { المطلب الثاني }
$$

موقف القانون الفرنسي والمصري

\section{من تكريس حق الطقل في الاستماع إليه في الخصومة المدنية}

رأينا في المطلب الأول من هذا المبحث موقف المعاهدات الدولية

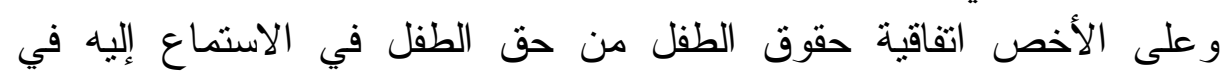

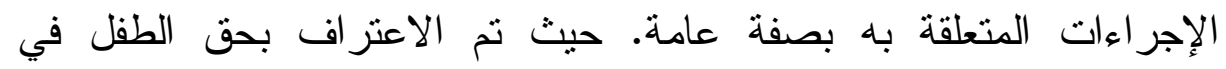

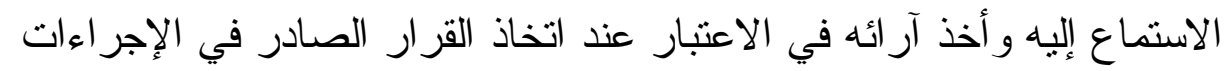

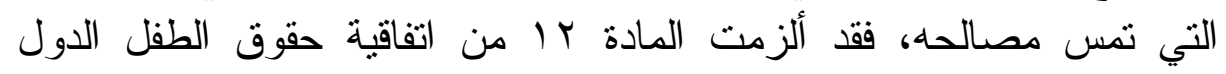

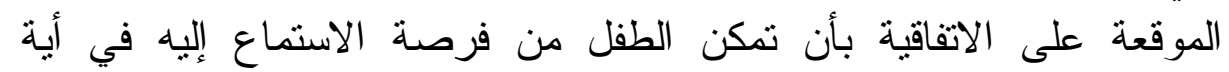

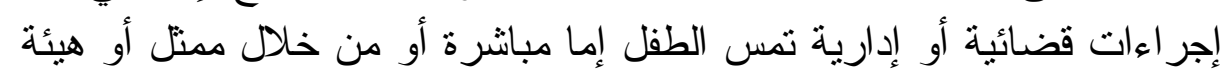

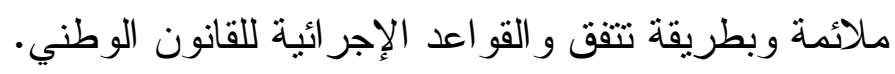

ونتتاول في هذا السياق قيمة نص المادة r ا من الاتفاقية الدولية لحماية حقوق الطفل في النظام القانوني الفرنسي و المصري، وناف ومدي إمكانية

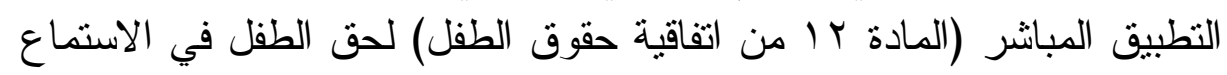

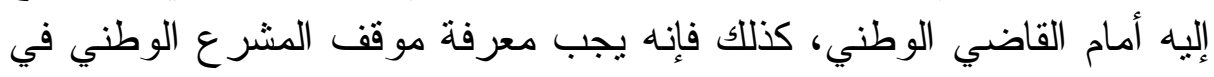

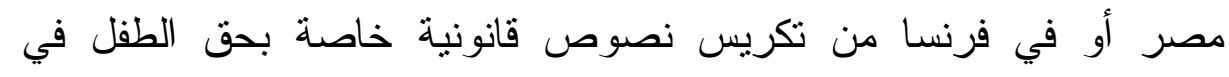
الاستماع إليه في الخصومة المدنية.

\section{الفرع الأول}

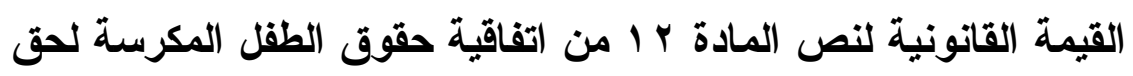

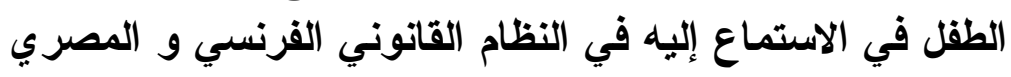

بادئ ذي بدء يمكن القول إن القيمة القانونية للاتفاقيات الدولية لا تثير أدنى جدل. حيث إنها نتمتع بقيمة إلزامية نحو الأطر اف الذين وقعو النية عليها. 
ومما لا شك فيه أن اتفاقية حقوق الطفل لعام 919 أتعد من قبيل الاتفاقيات

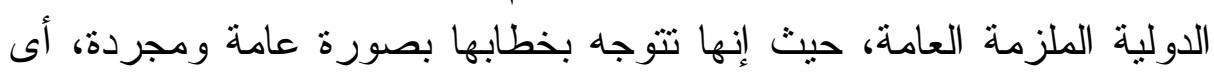

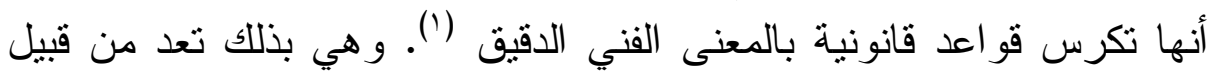

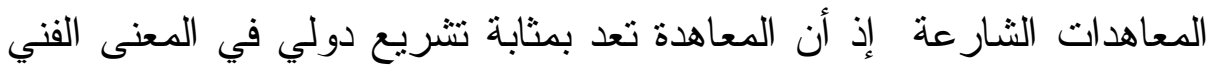

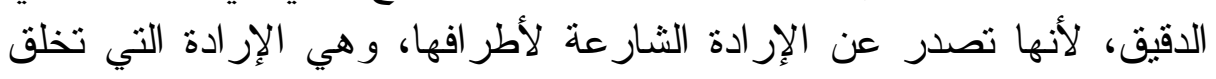

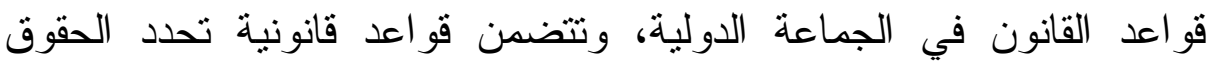

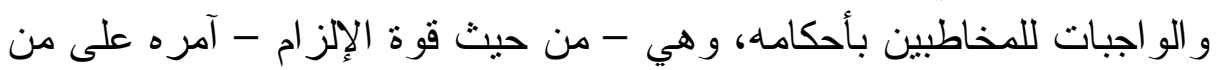

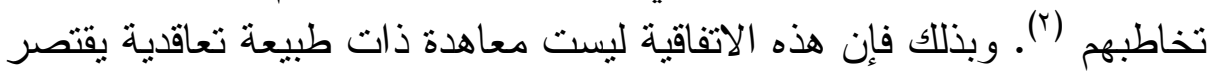

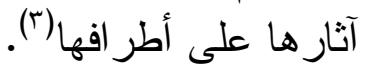

حيث إن الصفة المميزة للمعاهدات الثارعة هو التوجه إلى المجتمع

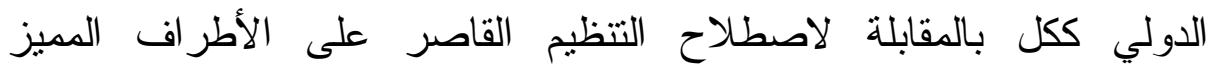

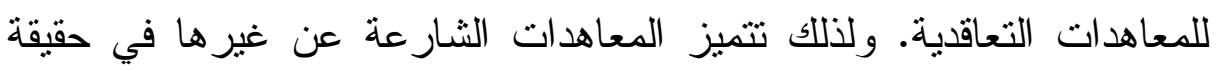

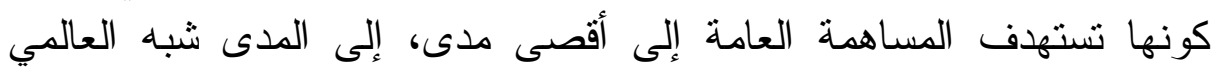

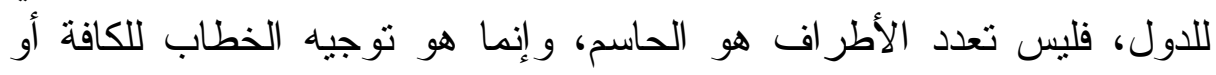

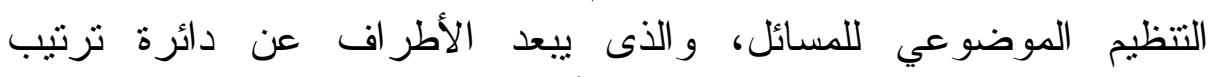

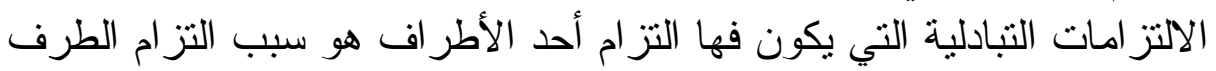

الآخر (ع).

و لا شك - أيضاً - أن اتفاقية حقوق الطفل إنما تدخل في عداد

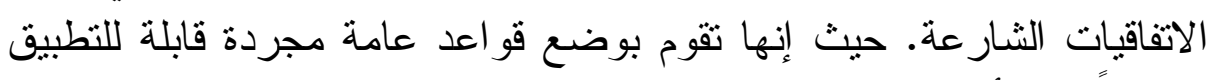

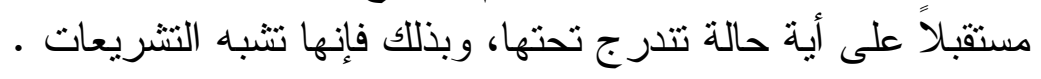

ومن حيث أطر افها، نجد أن اتفاقية حقوق الطفل 1919 التميز

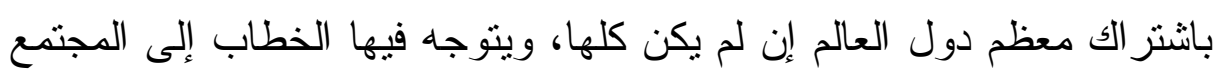

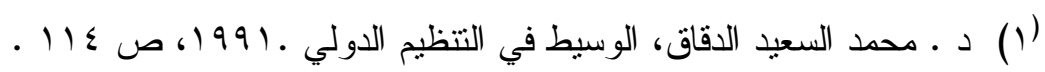

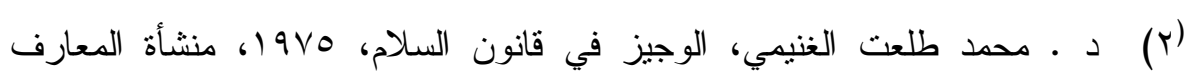

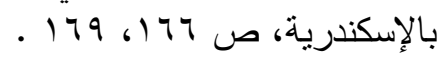

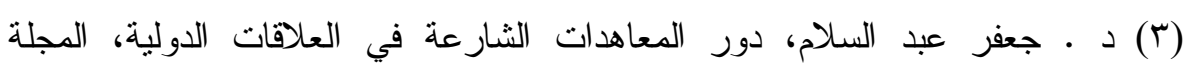

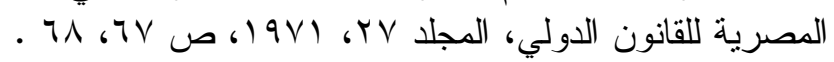

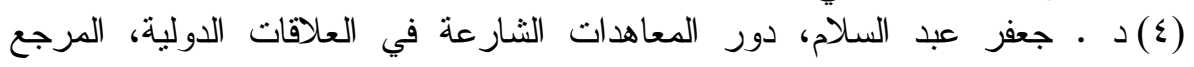
السابق، ص 79 . 19 . 
الدولي كله. و اتفاقية حقوق الطفل تلزم أكثر من التوات 19 دولة من دول العالم،

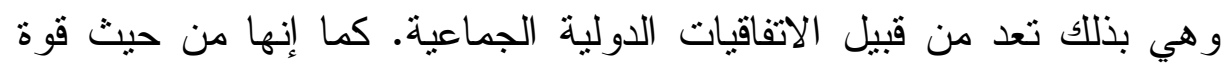

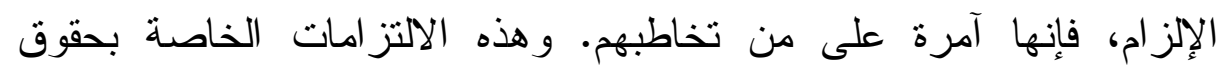

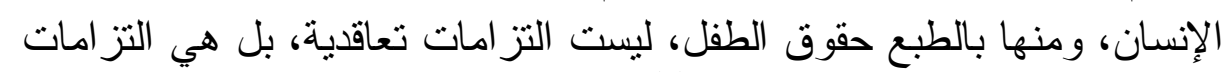

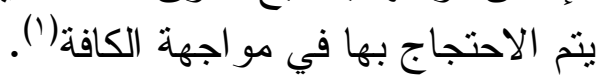

ويميز فقهاء القانون الدولى بين نوعين من الاتفاقيات الثارعة من

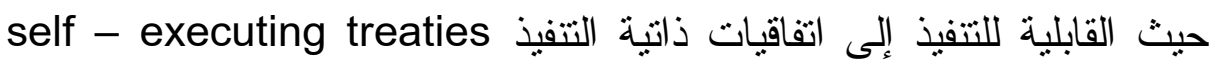

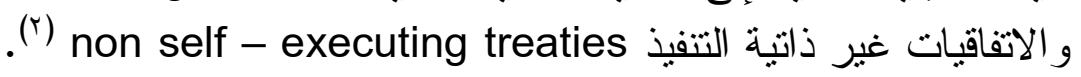

و المقصود بالاتفاقيات الدولية ذاتية التتفيذ تلك الاتفاقيات التي لا يحتاج

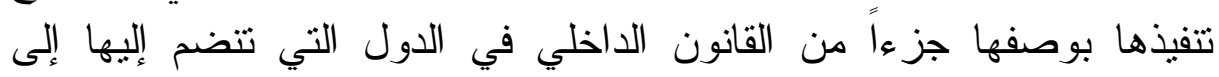

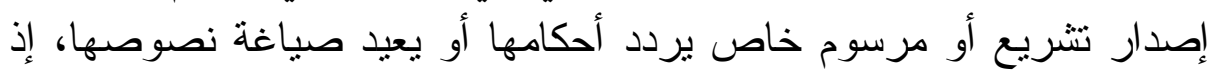

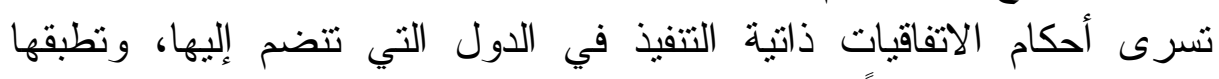

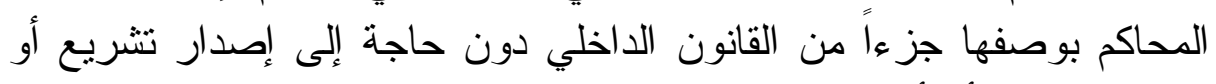

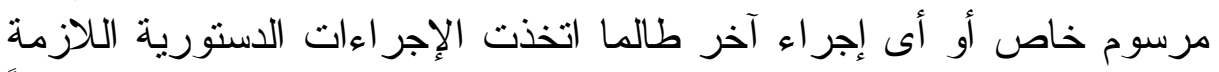

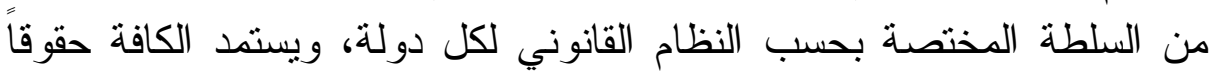

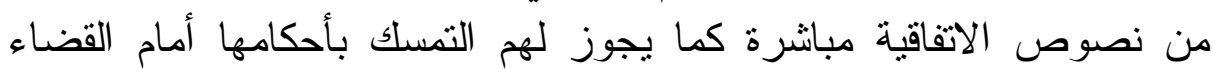
الوطني في كل دولة من الدول التي تتضم إليها.

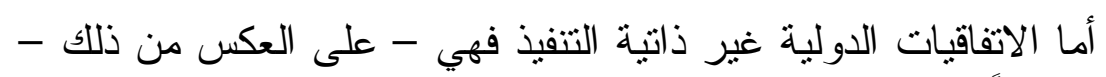

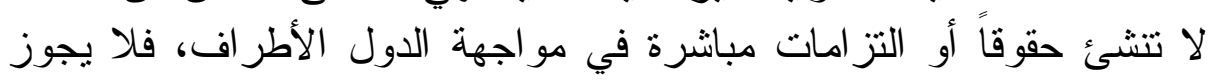

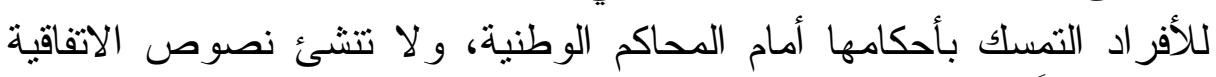

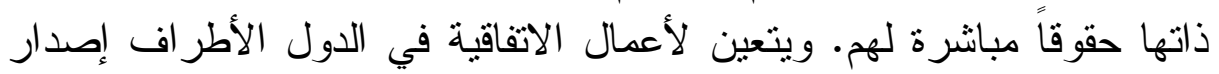

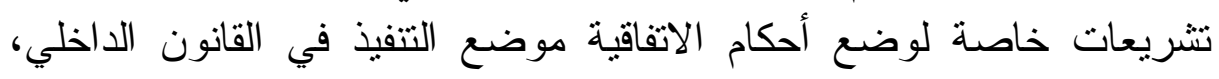

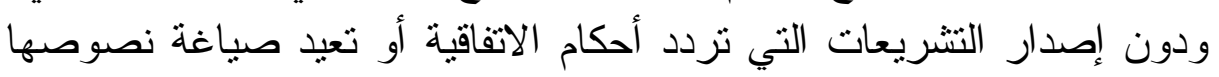

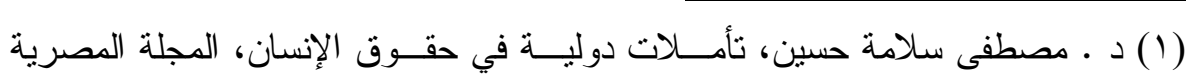

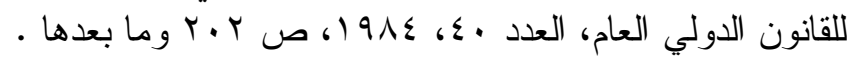

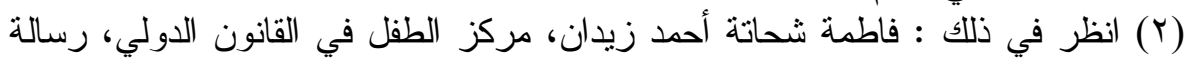

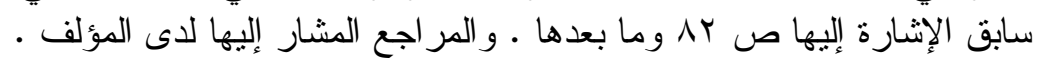


تظـلـل أحكام الاتفاقية جامدة وغير قابلة للتطبيق في الدول الأطر اف('). وفى هذا المقام يثور تساؤل هام، مفاده إنه إذا كان من الثابت أن

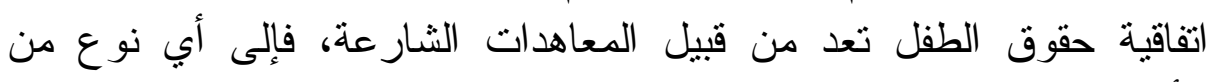
الأنو اع تتنمى هذه الاتفاقية من حيث قابليتها للتتفيذ التلقائي من عدمه.

أولا : الموقف في القانون المصري:

في الإجابة عن هذا التساؤل يذهب أغلبية الفقه المصري)(r)، إلى أن فئن

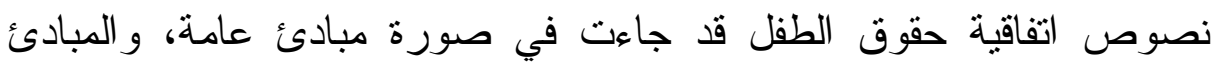

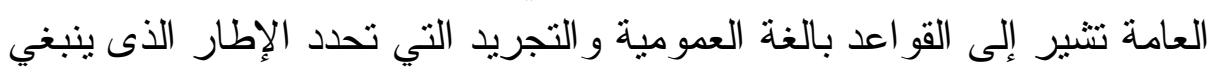

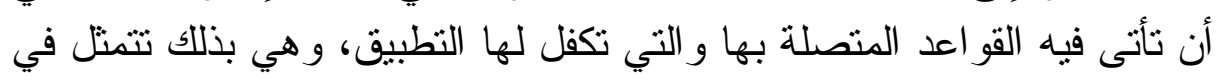

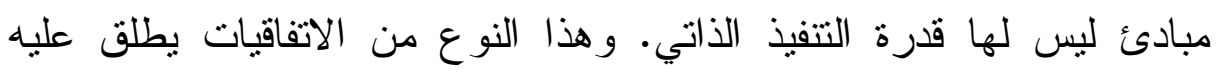

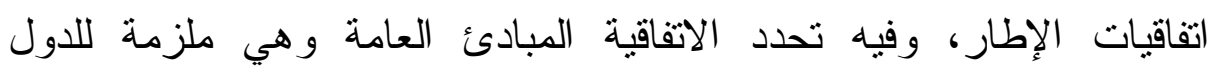

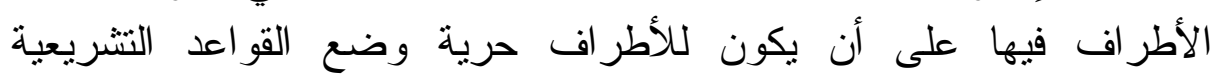

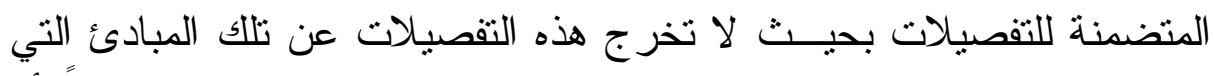

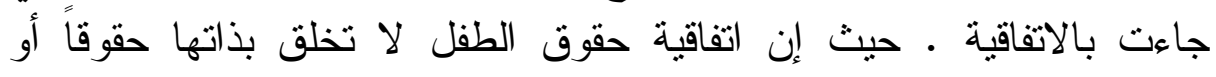

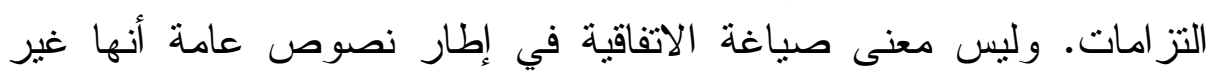

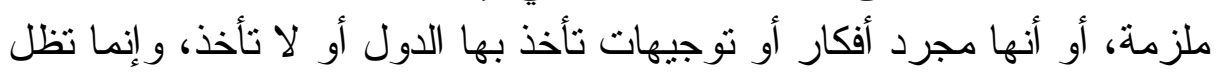

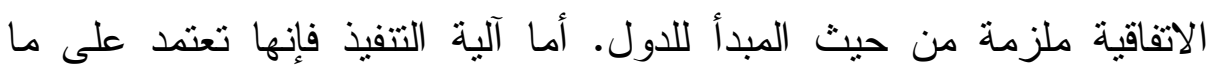

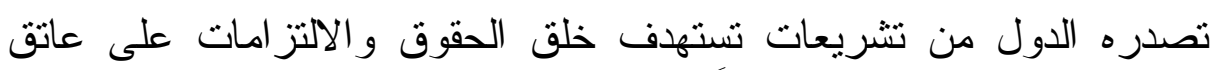

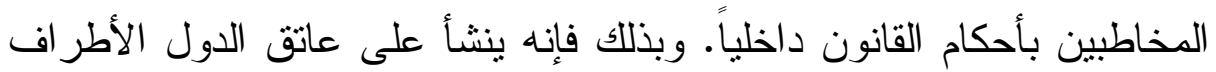

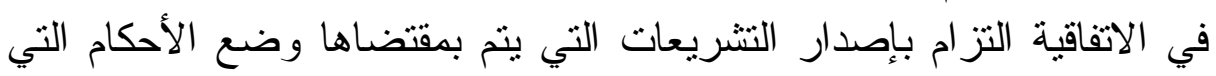

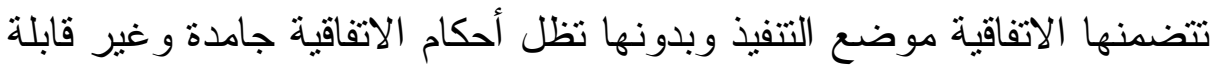

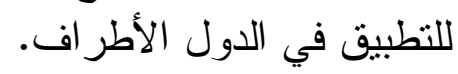

وقد نصت المادة r/T من الاتفاقية ذاتها على أنه " تتخذ الدول الأطر اف جميع التدابير المناسبة لتكفل للطفل الحماية من جميع أشنكال التمييز

(1) د . حسام الدين عبد الغنى الصغير، تفسير اتفاقية الأمم المتحدة بشأن عقود البيع

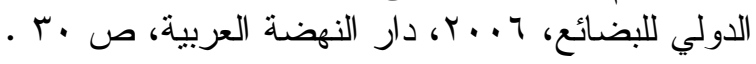

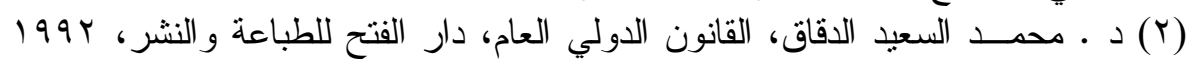

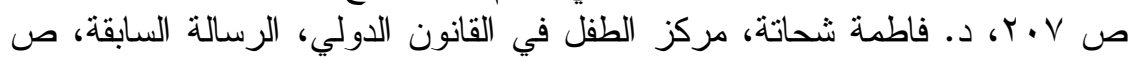

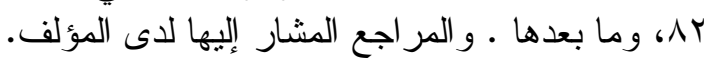


أو العقاب القائمة على أساس مركز و الديّ الطفل أو الأوصياء القانونين عليه

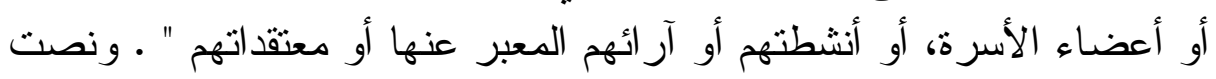

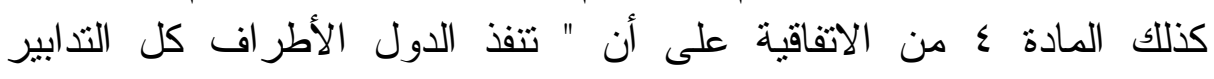

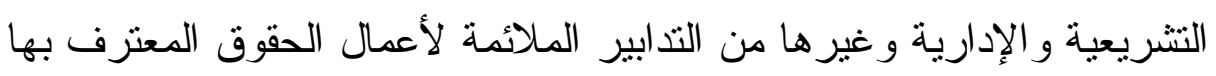

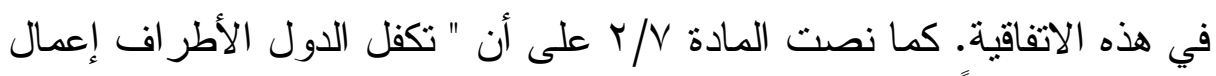

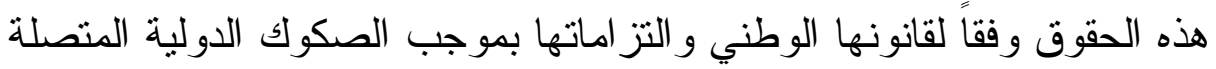

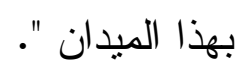

\section{ثانيا : الموقف في القانون الفرنسي:}

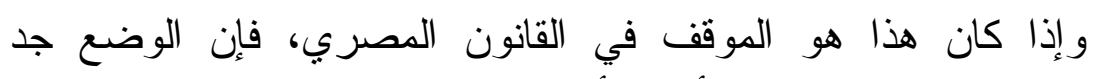

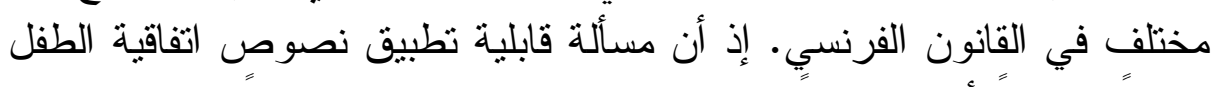

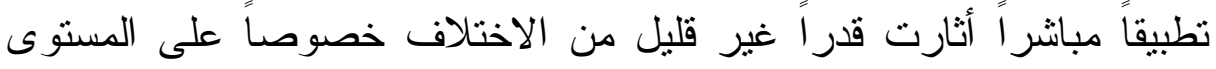

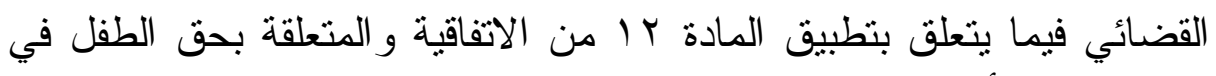
الاستماع إليه أمام القضاء.

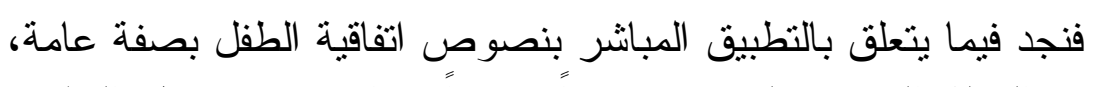

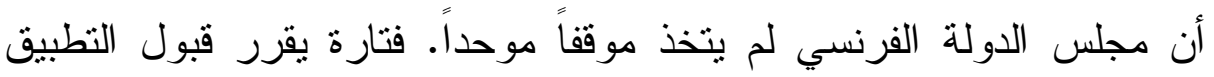

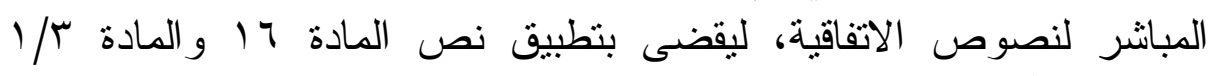

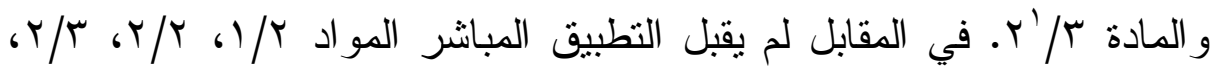

( $\left.{ }^{1}\right)$ Y. Benhamou, Courtes remarques sur la jurisprudence du Conseil d'État relative à la réception en droit français de la Convention de New York sur les droits de l'enfant : Gaz. Pal. 1995, 2, doctr. p. 899., C. Chabert, Pour un réexamen de la question de l'applicabilité directe de la Convention de New York du 26 janvier 1990 relative aux droits de l'enfant : JCP G 2003, I, p.129., O. Matocq et $\mathrm{T}$. Dupré, La parole de l'enfant en justice après la Convention de New York, in Mélanges D. Huet-Weiller : LGDJ 1994, p. 309., M.-C. Rondeau-RivierLa Convention des NationsUnies sur les droits de l'enfant devant la Cour de cassation, un traité mis hors jeu : D. 1993, chron. p. 203.

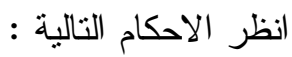

CE, 30 juin 1999 : D. 2000, jurispr. p. 1, note F. Boulanger et somm. p. 163, obs. C. Desnoyer.- CE, 6 oct. 2000 : Rec. CE 2000, 
(1) (0/

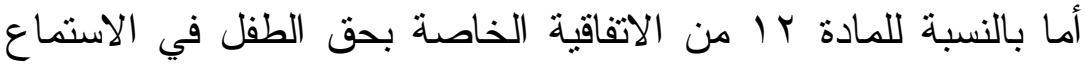

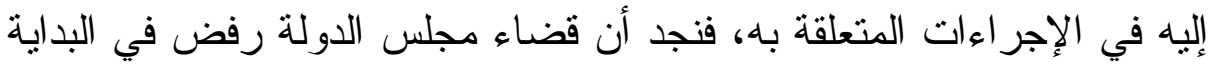

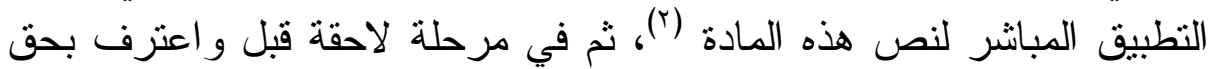

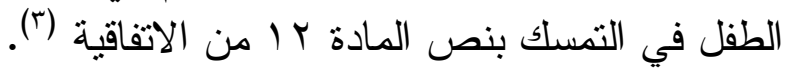

أما قضاء محكمة النقض الفرنسية، فقد استمر لمدة طويلة رافضاً التطبيق المباشر لنص المادة r ا من الاتفاقية على سند من القول أن أحكام

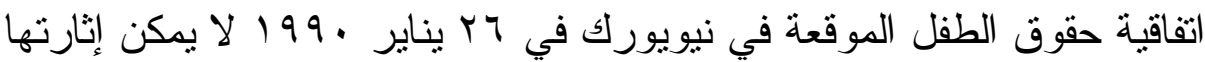
أمام المحاكم، حيث إن هذه الاتفاقية لا تتشأ إلا التزائ فات على على عاتق الدول

p. 391, à l'article 9 (CE, 29 juill. 1994 : RD sanit. soc. 1995, p. 167, note F. Monéger. — CE, 7 juill. 1999 : RJPF 1999-9/38, p. 24, obs. A. M. Blanc), aux articles 24-1, 26-1 et 27-1 (CE, 23 avr. 1997 : JCP G 1997, IV, 2091 ; D. 1998, jurispr. p. 15, concl. R. Abraham), 24, 26 et 27 (CE, 14 janv. 1998 : JCP G 1998, IV, 2398). Déclarant l'article 7 de la Convention non invocable par les particuliers (CAA Marseille, 4 avr. 2005, n 03MA00042).

(1) CE, 10 mars 1995 : JCP G 1997, I, 3996, obs. J. Rubellin-Devichi ; D. 1995, jurispr. p. 617, note Y. Benhamou ; RTD civ. 1996, p. 140, obs. J. Hauser), à l'article 3-1 (CE, 22 sept. 1997 : JCP G 1998, II, 10052, note A. Gouttenoire-Cornut ; Dr. famille 1998, comm. 56, note P. Murat ; JCP G 1998, I, 101, obs. T. Fossier ; RTD civ. 1998, p. 76, obs. J. Hauser ; RGDP 1998, p. 336, note P. Murat ; LPA 26 janv. 1998, p. 17, note M. Reydellet. - CE, 12 oct. 2005 : JurisData $\mathrm{n}^{\circ}$ 2005-069112. - CAA Paris, 19 juill. 2005, $\mathrm{n}^{\circ}$ 05PA00088 et 05PA00089. - CAA Nancy, 28 mai 2007, $\mathrm{n}^{\circ}$ 06NC01351. - CAA Nancy, 10 déc. 2007, n 06NC00917), ainsi qu'à l'article 3-2 de la convention (CE, 5 oct. 2000 : Rec. CE 2000, p. 391).

$\left({ }^{2}\right)$ CE, 3 juill. 1996 : JCP G 1997, I, 3996, obs. J. Rubellin-Devichi ; JCP G 1996, IV, n 2279, note M. C. Rouault ; Dr. famille 1997, comm. 9, note P. Murat.

(3 ) CE, 27 juin 2008, n 29156 ; JCP G 2008, IV, 2381 et I, 206, n 1, obs. Y. M. Serinet ; AJF 2008, p. 342, obs. F. Chenedé. 
الأطر اف وغير قابلة للنطبيق المباشر في القانون الداخلي (').

إلا أنها بحكمها الصادر في 11 مايو ؟ . . ب قررت أن الطفل القادر

(1) Cass. 1re civ., 10 mars 1993 : D. 1993, jurispr. p. 361, obs. J. Massip. - J. Hauser : RTD civ. 1993, p. 341 et 572. - JCP G 1993, I, 3688. - Cl. Neirinck et Ph. Martin, : JCP G 1993, I, 3677. - E. Picard, obs. : JCP G 1993, I, 3700. - M.-C. Rondeau-Rivier, La Convention des Nations-Unies sur les droits de l'enfant devant la Cour de cassation, un traité mis hors jeu : D. 1993, chron. p. 203. - Cass. 1re civ., 2 juin 1993 : D. 1994, somm. p. 34, obs. F. Dekeuwer-Defossez. - Cass. 1re civ., 15 juill. 1993 : JCP G 1994, II, 22219, note Y. Benhamou ; D. 1994, jurispr. p. 191, note J. Massip ; JCP G 1994, I, 3729, obs. J. Rubellin-Devichi. : Cass. soc., 13 juill. 1994 : D. 1995, jurispr. p. 91, note J. Massip ; JCP G 1995, IIp. 22363, note Y. Benhamou ; Defrénois 1994, art. 35945, obs. J. Massip ; D. 1996, somm. p. 38, obs. X. Pretot ; JCP G 1995, I, 3813, obs. J. Rubellin-Devichi. - Cass. 1re civ., 4 janv. 1995 : Bull. civ. 1995, I, n 1 ; JCP G 1995, I, 3855, obs. H. Bosse-Platière ; Defrénois 1995, art. 36145, obs. J. Massip ; RTD civ. 1995, p. 347, obs. J. Hauser. - Cass. crim., 18 juin 1997 : Defrénois 1998, art. 36753, obs. J. Massip ; Dr. famille 1998, comm. 56, note P. Murat. - Plus nuancé, Cass. 1re civ., 25 juin 1996 : Bull. civ. 1996, I, nº 268 ; JCP G 1997, II, 22834, note Ph. Malaurie ; Defrénois 1997, art. 36516, obs. J. Massip ; RTD civ. 1996, p. 873, obs. J. Hauser.

$\left(^{2}\right)$ Cass. 1re civ., 18 mai 2005 : Bull. civ. 2005, I, n 211 ; JCP G 2005, II, 10081, note F. Granet-Lambrechts et Y. Strickler ; JCP G 2005, II, 10115, note C. Chabert, concl. C. Petit ; JCP G 2005, I, 199, n 8, obs. J. Rubellin-Devichi ; Dr. famille 2005, comm. 156, note A. Gouttenoire ; Rev. Lamy dr. civ. juill.-août 2005, $\mathrm{n}^{\circ} 18$, 752, p. 47, obs. G. Marraud des Grottes ; RJPF 2005-9 /31, p. 21, note F. Eudier ; D. 2005, p. 1909, note V. Egéa ; D. 2005, p. 2790, note F. Boulanger ; AJF 2005, p. 274, note Th. Fossier ; RTD civ. 2005 , p. 585 , obs. J. Hauser, p. 627 , obs. Ph. Théry, p. 750, obs. P. Rémy-Corlay ; Defrenois 2005, art. 38230, p. 1418, note J. Massip ; Rev. crit. DIP 2005, p. 679, note D. Bureau ; Dr. et patrimoine 


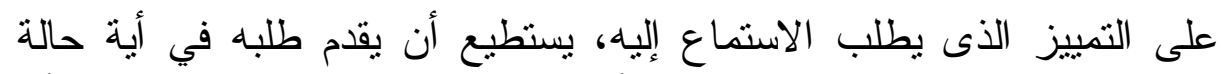

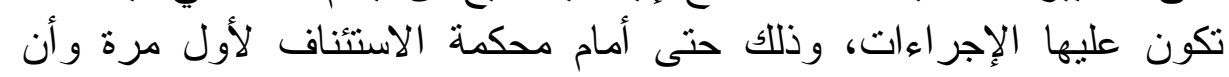

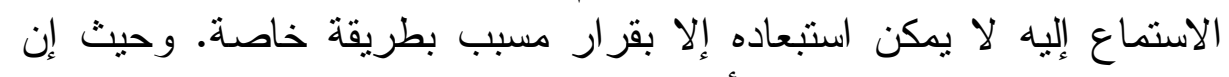

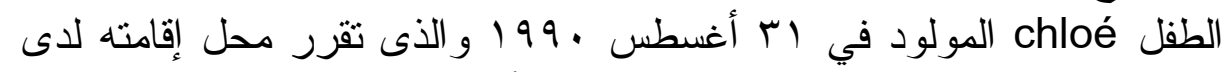

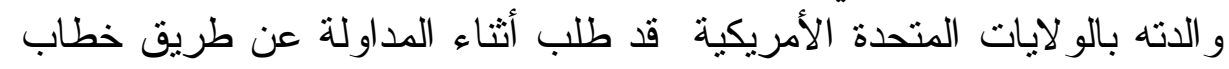

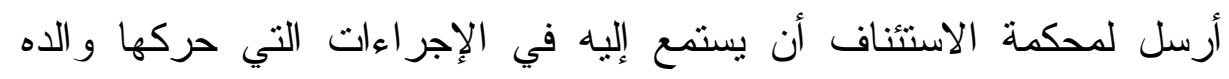

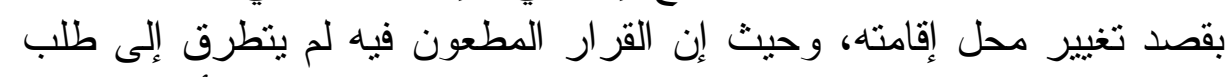

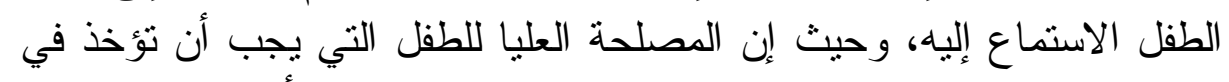

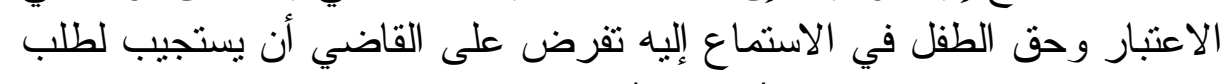

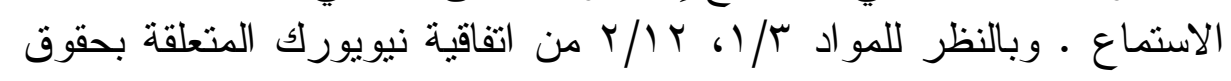

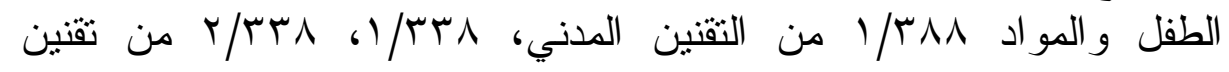

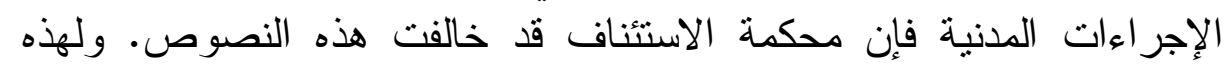

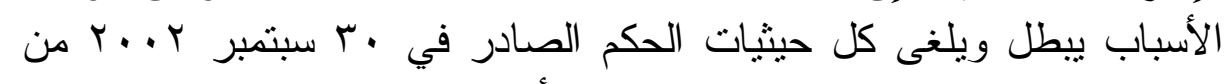

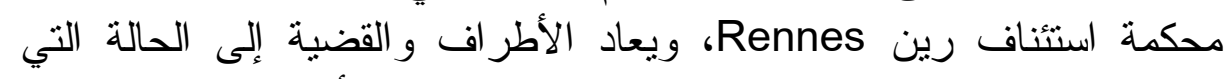

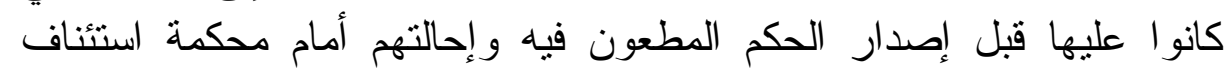
. Angers

و هكذا فإن محكمة النقض الفرنسية قد اعترفت بالتطبيق المباشر

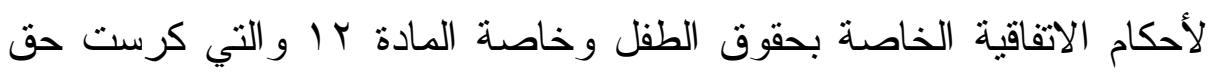

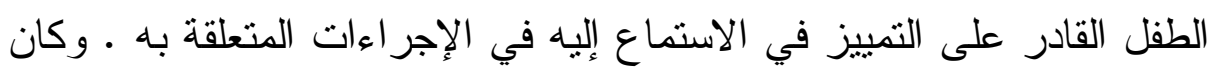

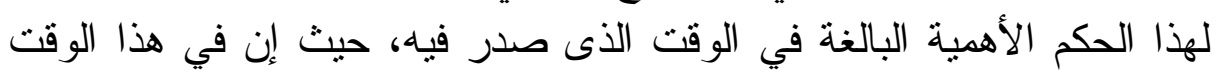

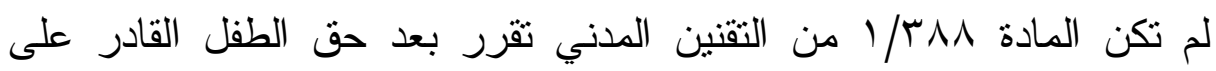

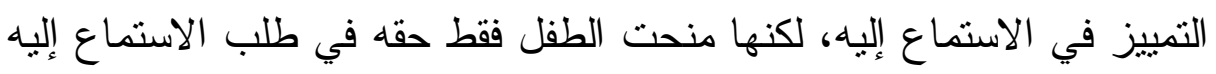

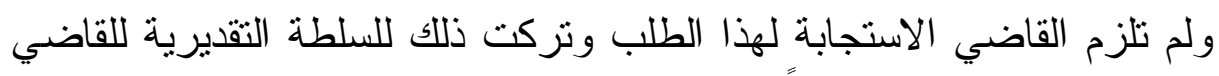
الذى ينظر الطلب ـ وترتيباً على هذا الحكم تولا للطفل حقه في الاستماع إليه

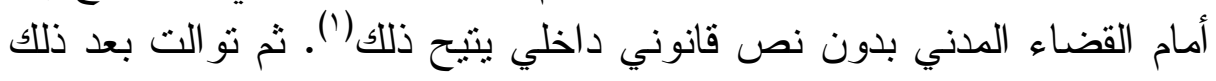

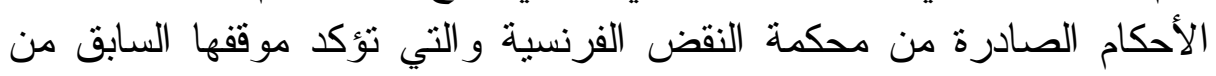

sept. 2005, p. 101, note Ph. Bonfils ; Gaz. Pal. 2005, jurispr. p. 2664, note A.S. Courdier-Cuisinier.

$\left(^{1}\right)$ C.Watine-Drouin, Minorité.-Audition du mineur en justice.Défense de ses intérêts, op.cit., n 11.p.15. 
تطبيق المادة r ا من اتفاقية حقوق الطفل أمام المحاكم الفرنسية('). الفز ع الثاني

\section{موقف المشرعين الفرنسي والمصري من تكريس حق الطقل في الاستماع

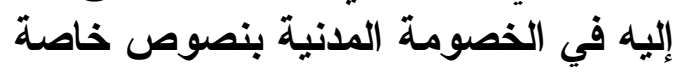

لقد كان للقانون الفرنسي موقفاً أكثر تطور وعمق من نظيره المصري في تكريس حق الطفل في الاستماع اليه في الخصومة المدنية. فقد تطور موقف المشرع الفرنسي من تكريس حق الطفل في الاستماع إلبه في الخصومة المدنية خلال السنو ات الأخيرة. ويمكن رصد تطور موقف المشر ع الفرنسي من خلال التفرقة بين ثلاث مر احل زمنية: مرحلة ما قبل القانون رقم

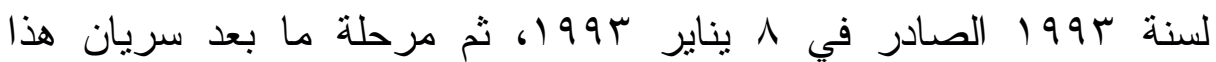

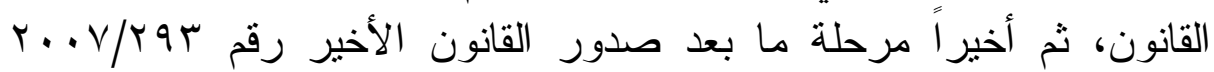

( $\left.{ }^{1}\right)$ Cass. 1re civ., 13 juill. 2005 : Bull. civ. 2005, I, n 334 ; Dr. famille 2006, comm. 42, note M. Farge ; D. 2005, p. 2339), : Cass. 1re civ., 8 nov. 2005 : Bull. civ. 2005, I, n 404 ; Dr. famille 2006, comm. 28, note A. Gouttenoire ; RJPF 2006-2/48, p. 27, obs. F. Eudier ; RTD civ. 2006, p. 101, obs. J. Hauser ; D. 2006, p. 554, note F. Boulanger), : Cass. 1re civ., 22 nov. 2005 : Bull. civ. 2005, I, n 434 ; D. 2005, p. 3036, obs. I. Gallmeister, et D. 2006, p. 554, note F. Boulanger ; Dr. famille 2006, comm. 28, note A. Gouttenoire ; RTD civ. 2006, p. 101, obs. J. Hauser ; Rev. Lamy dr. civ. 2006, $\mathrm{n}^{\circ}$ 24, 1002, p. 41, obs. G. Marraud : Cass. 1re civ., 22 mai 2007, $n^{\circ}$ 06-12.687 : JurisData $n^{\circ}$ 2007-038911 : Cass. 1re civ., 14 mars 2006 : RJPF 2006-7-8/41, p. 21, note F. Eudier : Cass. 1re civ., 7 avr. 2006 : Dr. famille 2006, comm. 124, note P. Murat ; RTD civ. 2006, p. 273, obs. P. Rémy-Corlay, p. 292, obs. J. Hauser : Cass. 1re civ., 13 mars 2007 : Dr. famille 2007, comm. 125, note P. Murat ; RTD civ. 2007, p. 330, obs. J. Hauser ; JCP G 2007, I, 102, n 5, obs. Y. Favier ; RJPF 2007-6/41, p. 28, note F. Eudier : Cass. 1re civ., 22 mai 2007 : Dr. famille 2007, comm. 155 , note M. Farge). 


$$
\text { الصادر في } 0 \text { مارس V ... Y ('). }
$$

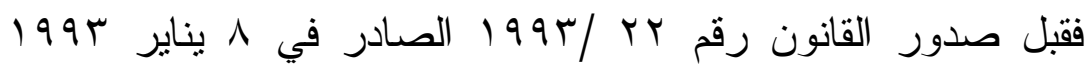

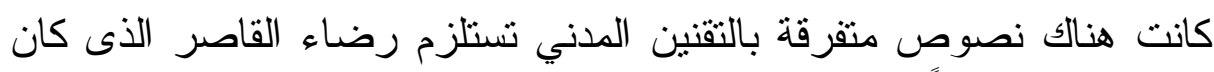

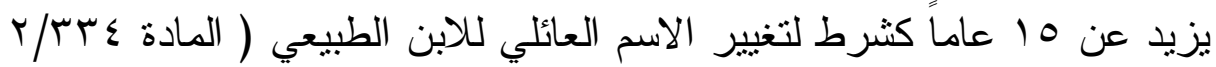

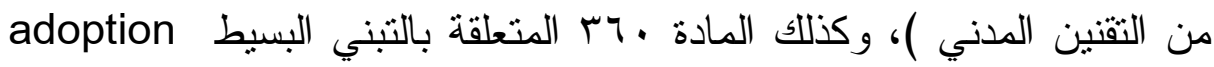
كان simple

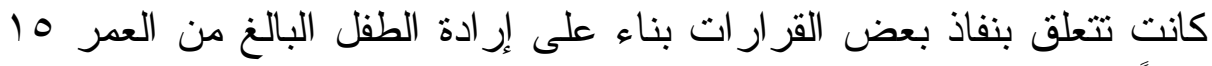

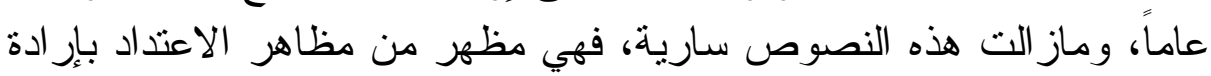

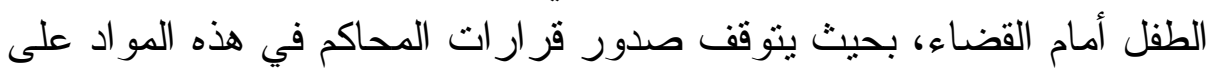

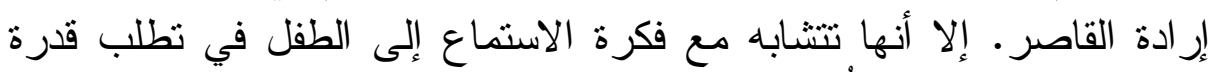

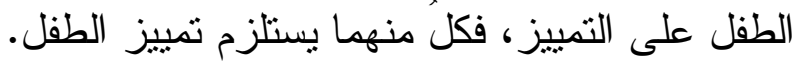

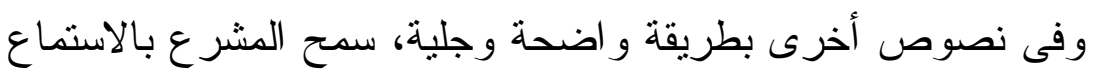

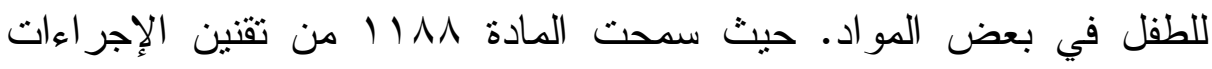

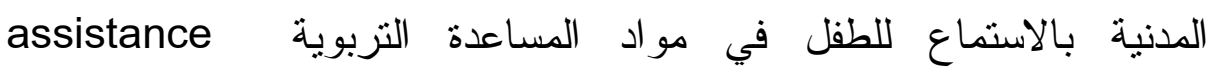

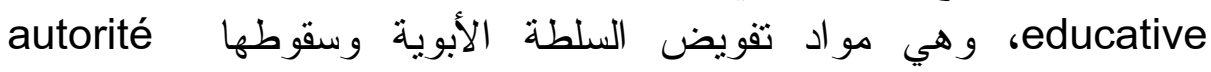
parental

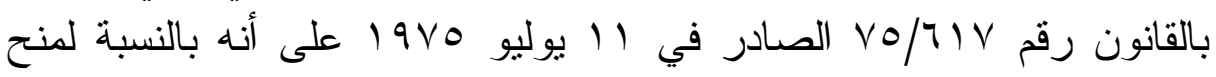

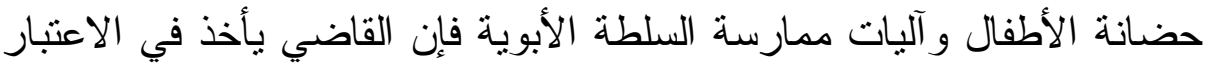

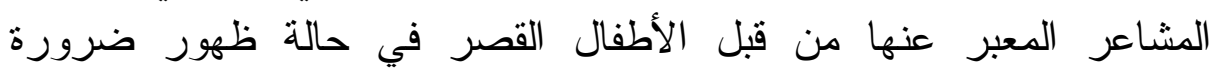

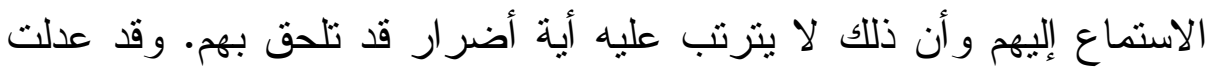

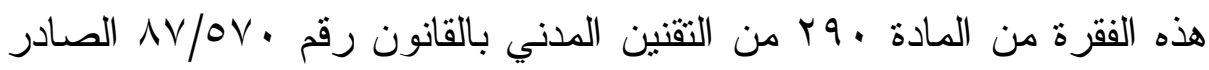

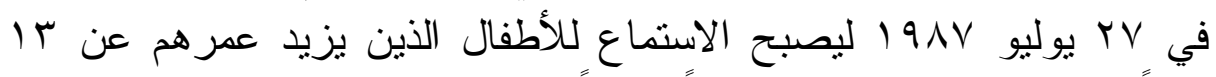

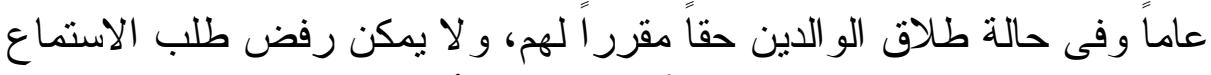

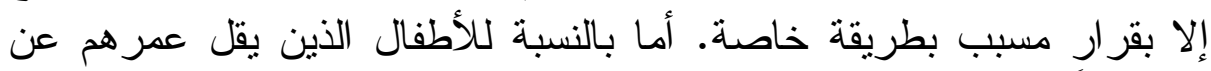

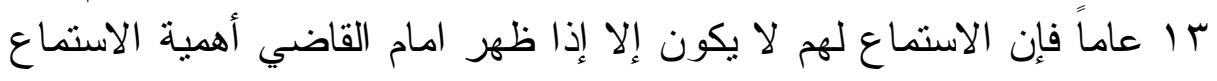

(1) C. Watine-Drouin, Minorité-- Audition du mineur en justice .Défense de ses intérêts, op.cit. n 28,p.34, Y. Benhamou, Réflexion en vue d'une meilleure défense en justice de l'enfant : D. 1993, chron. p. 103. 
إلى الطفل و عدم ترتيب ذللك أية أضر ار للطفل.

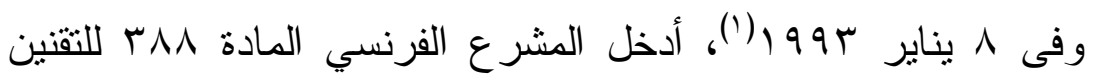

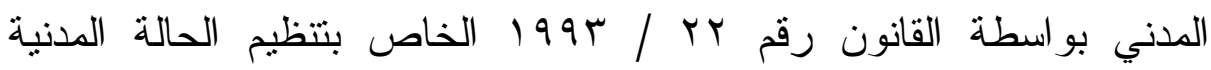
و الأسرة وحقوق الطفل و بإنشاء قاضي الثشئون الأسرية، وذلك بهدف ألكان أعمال

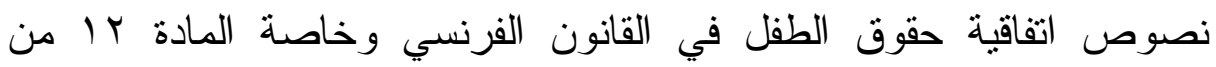

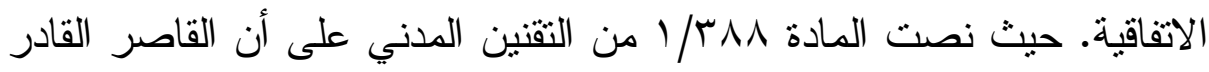

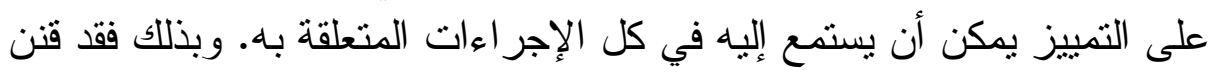
المشرع إمكانية الاستماع للطفل في كافة الإجر اءات المتعلقة بالطفل. إلا إنه إنه

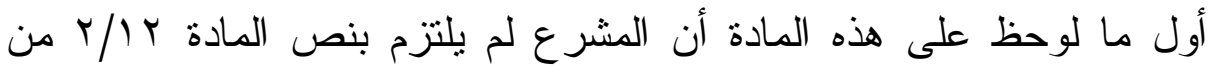
اتفاقية حقوق الطفل و التي كرست صر احة حق الطفل في الاستماع إليه. حيث تزكت قبول طلب الطفل الاستماع إليه لسلطة القاضي التقديرية، ولم يتمتع الطفل حسب صياغة هذه المادة بحق في الاستماع إليه في الخصومة المتنعلقة

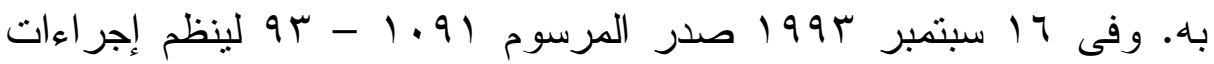
الاستماع للطفل أمام القضاء المدني تحت عنوان الاستماع للطفل أمام العدالة.

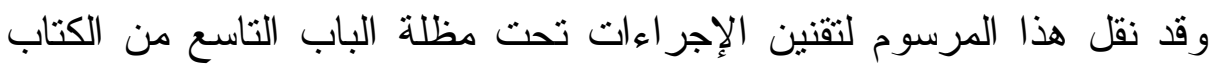
الأول لهذا التقنين بالفقر ات الأولى إلى الفقرة التاسعة من المادة مبس. تحس.

وبذللك لم يكرس المشرع الفرنسي للطفل الحق في الاستماع إليه في الخصومة المدنية، وإز اء ذللك قدمت عدة تقارير لتكريس هذا الحق تشريعياً. فقى التقرير السنوي للمدافع عن الأطفال Du defenseur des enfents

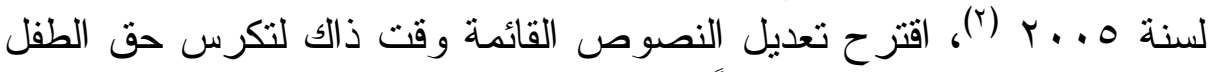

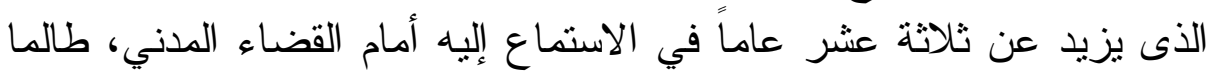

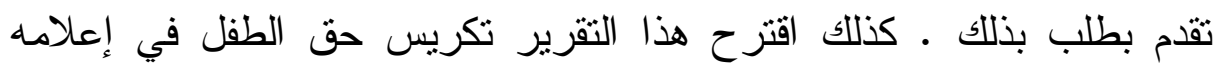
بوجود إجر اءات متعلقة به بواسطة القاضي، وحقه في تمثيله في الإجر اءات

(1) J. RUBELLIN-DEVICHI, Une importante réforme en droit de la famille : la loi n. 93-22 du 8 janvier 1993,JCP G, n 12, 24 Mars 1993, I p.3659.

$$
\text { : (r) (نظر في ذلك }
$$

C. Watine-Drouin, Minorité,-Audition du mineur en justice. Defense de ses interets,op.cit. n 4.p.7. 


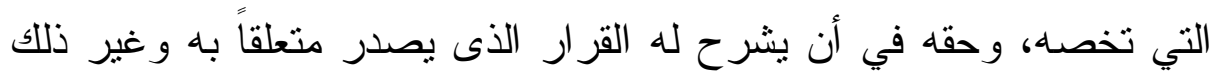

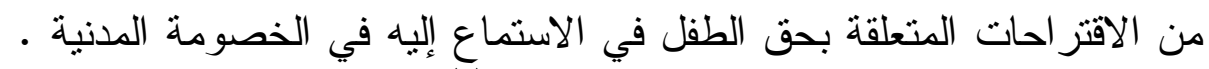

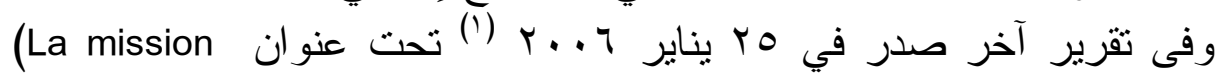
d'information sur la famille et les droits de l'enfant )

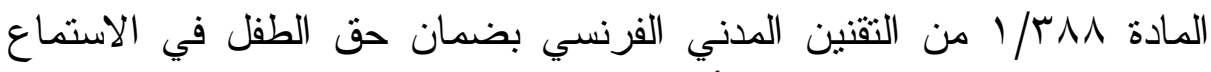
إليه، حيث إن القاضي يستطيع أن يستبعد طلب الطفل في الاستماع إليه بدون

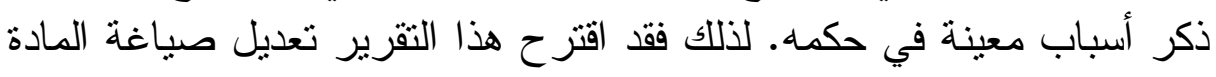

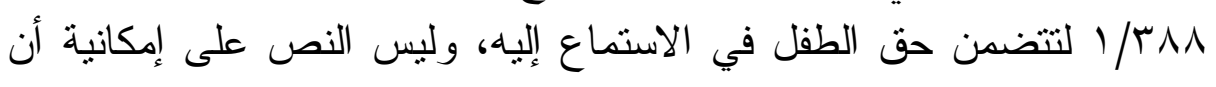
يستمع إليه في الخصومة المدنية . لين الفن

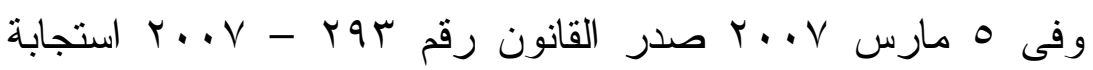

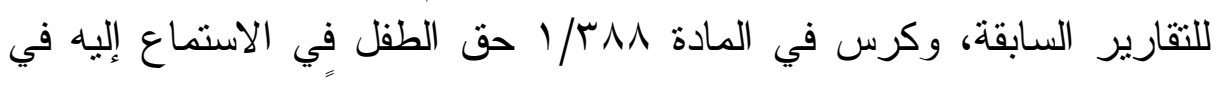
الإجر اءات المتعلقة به . حيث تتص هذه المادة - طبقاً لصياغتها الجديدة-

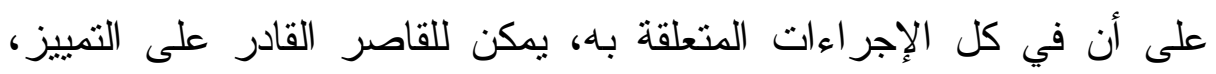

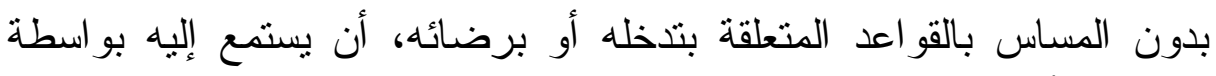

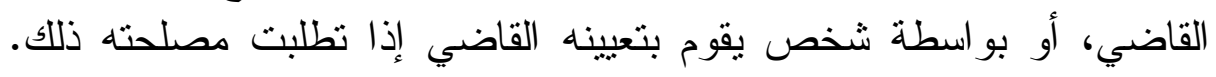

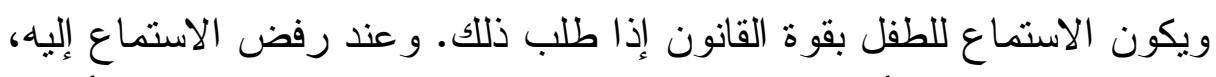

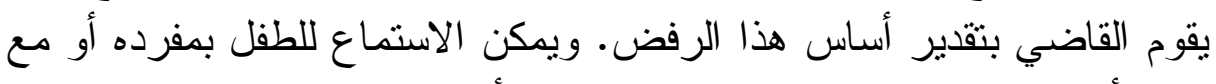

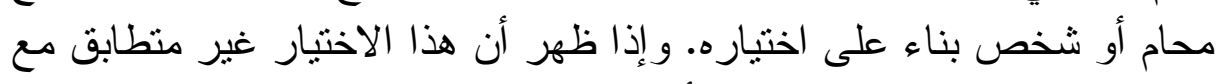

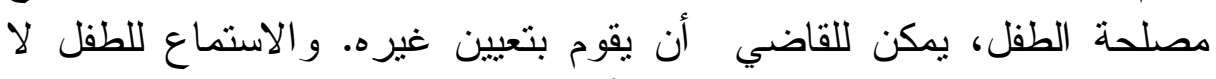

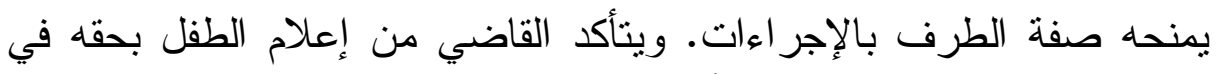
الاستماع إليه وحقه في مساعدة أحد المحامين.

وهكذا فإن المشرع الفرنسي قد اعترف بحق الطفل في الاستماع إليه

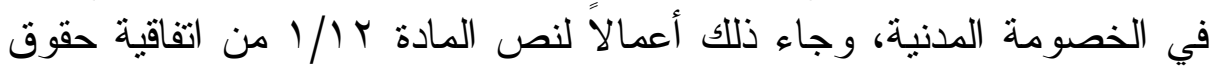

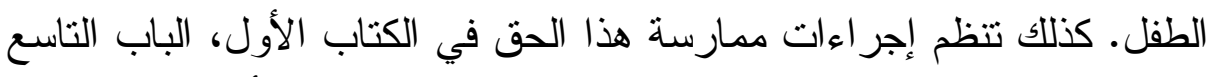

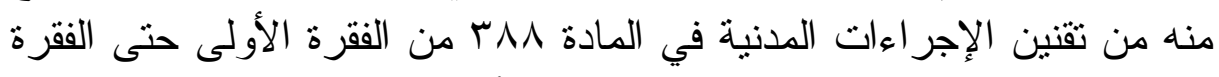

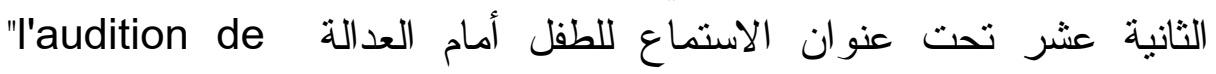
"l'enfant en justice"

${ }^{(1)}$ C. Watine-Drouin, Minorité,-Audition du mineur en justice. Defense de ses interets, op.cit., n 5.p.8. 
كرسها المشرع لممارسة الطفل لحقه في الاستماع إليه في الخصومة المدنية من خلال الفصل الثاني من هذه الدر اسة.

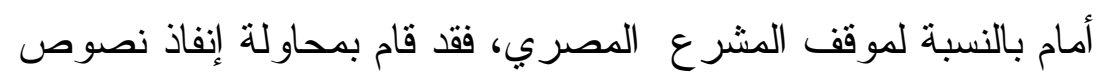

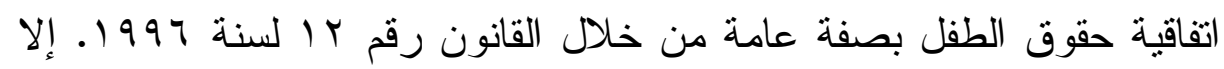

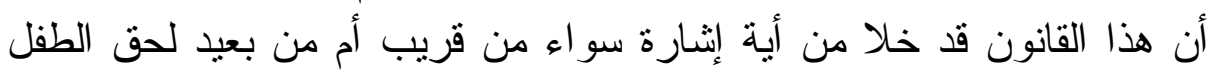

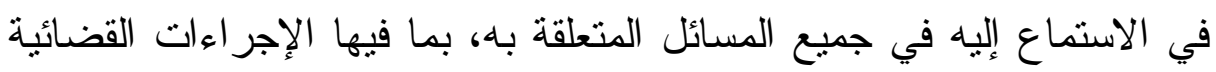

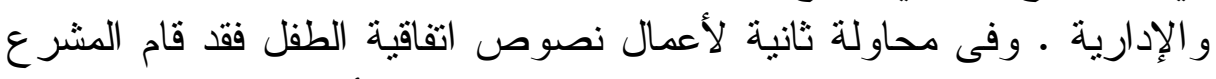

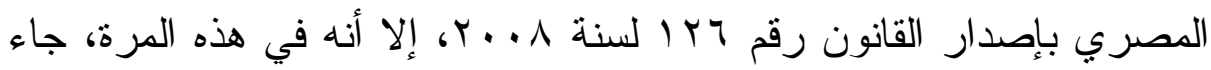

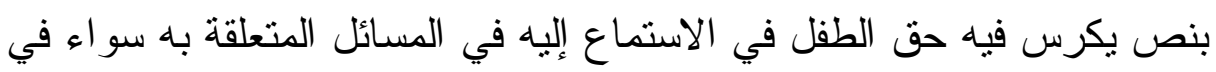

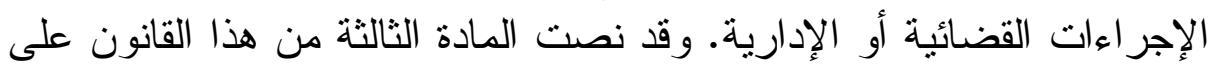

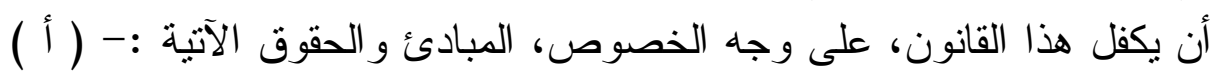

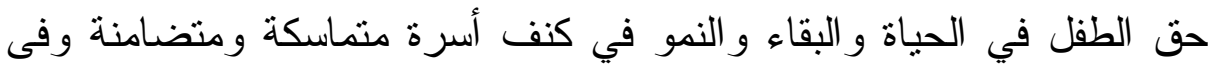

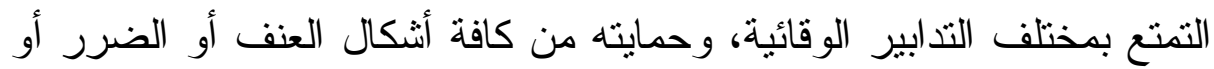

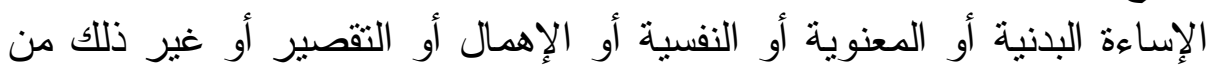

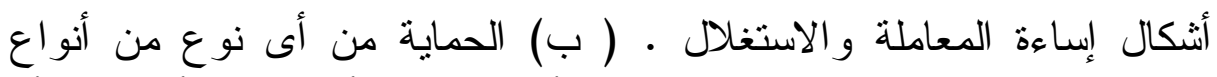

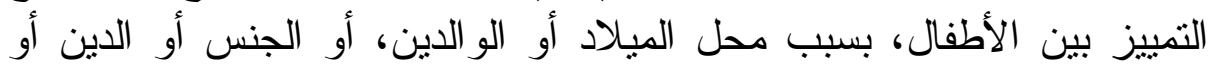

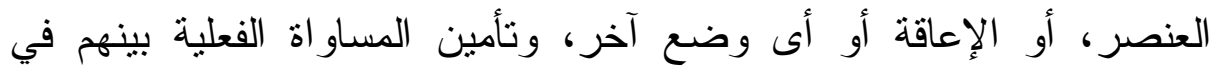

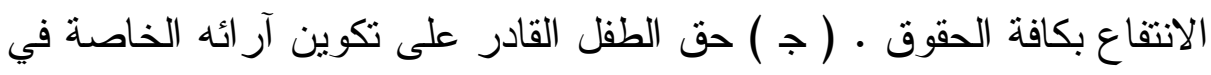
الحصول على المعلومات التي تمكنه من تكوين هذه الآراء وفى التى التعبير عنها

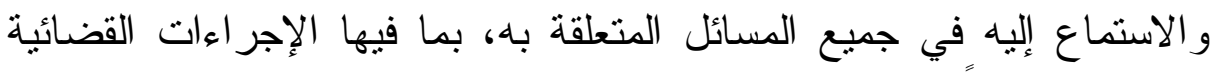

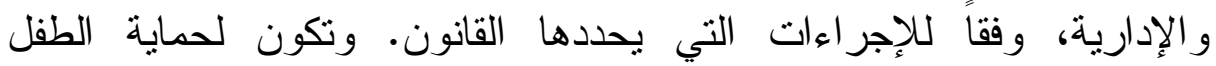

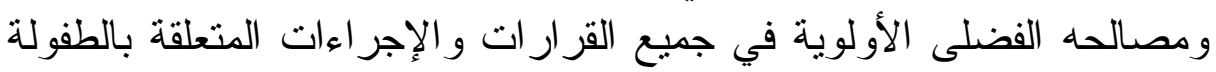

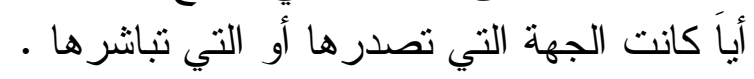

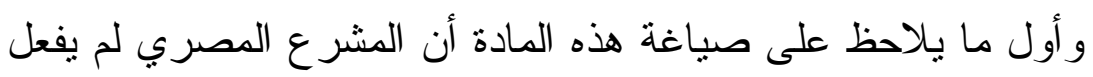

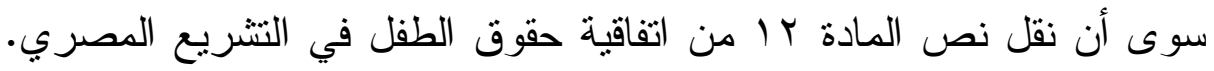

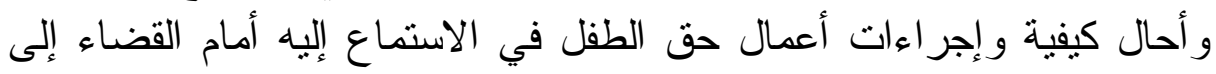

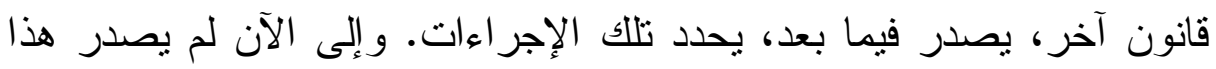
القانون لينظم هذه الإجر اءات. وبناء على ذلك فقد تبنى المشرع المصري في قانون الطفل وكرس 
حق الطفل في الاستماع إليه في المسائل المتعلقة به، بما فيها الإجراءات

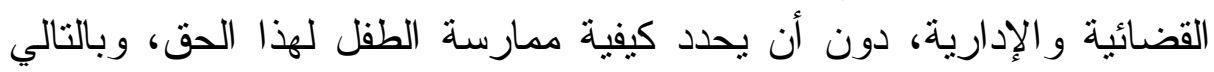

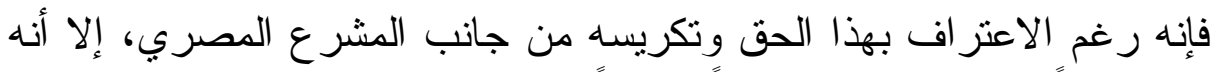

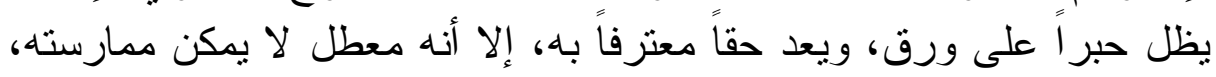

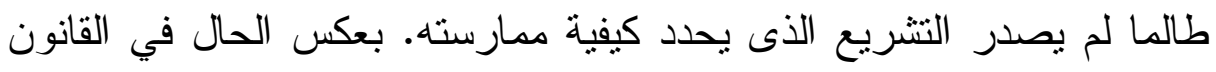

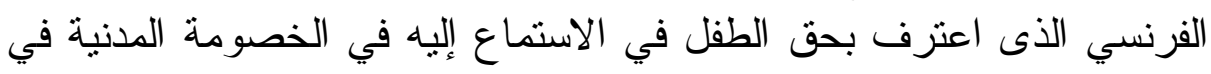

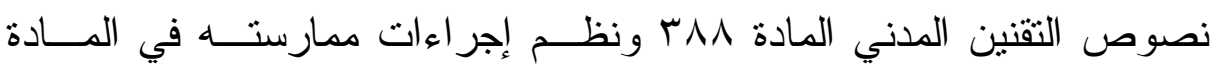
يسT بفقر اتهــا الاثتى عشر كما سنري في الفصل الثاني من هذه الدر اسة.

وتجدر ملاحظة أن المشرع المصري قد أثشار بطريقة ضمنية لفكرة

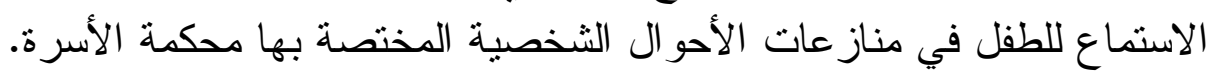

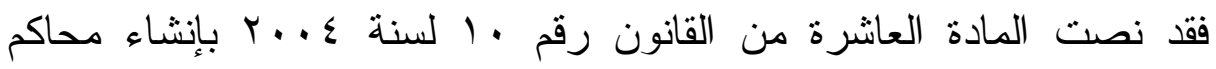

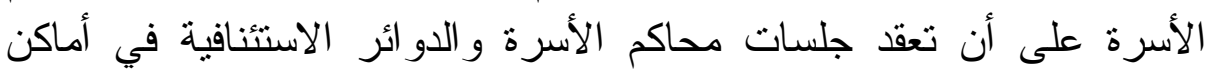

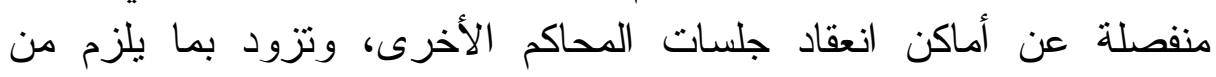

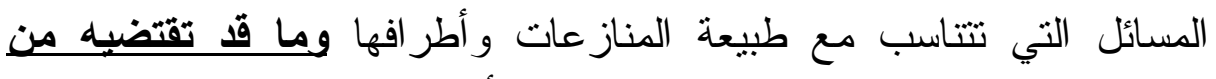

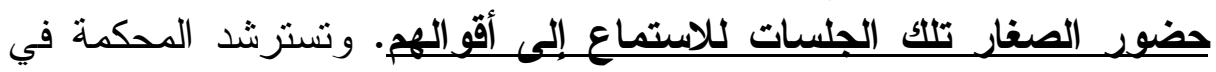

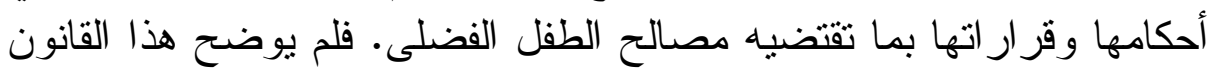

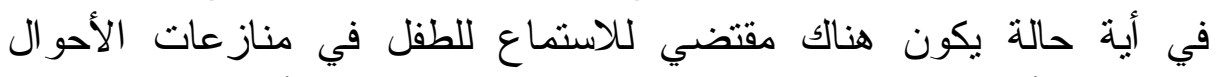

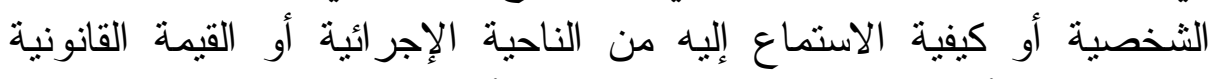

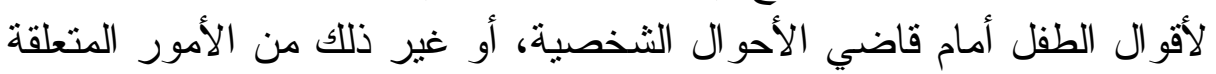
بالاستماع للطفل.

\section{المبحث الثالث}

\section{مناط حق الطقل في الاستماع إليه \\ في الخصومة المدنية}

مناط حق الطفل في الاستماع إلِِه في الإجر اءات القضائية والإدارية

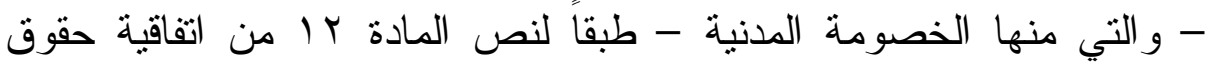

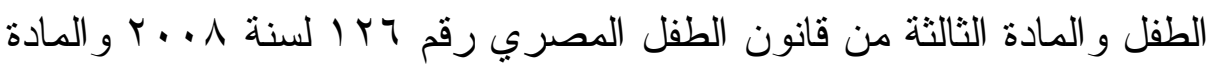

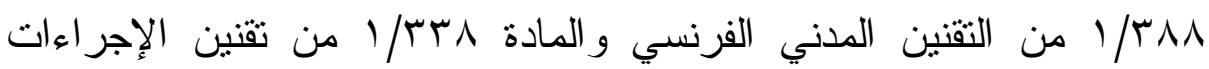

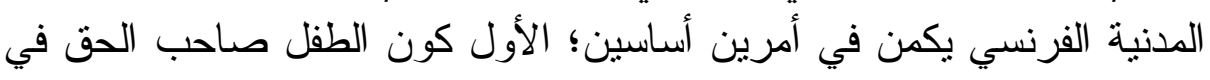

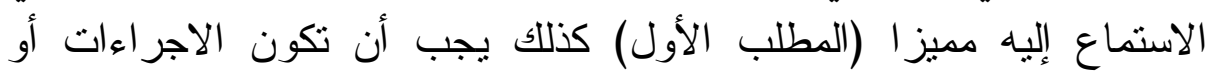




$$
\text { الخصومة المدنية متعلقة به (المطلب الثاني) · }
$$

قرة الطفل المراد الاستماع إليه على التمييز

لا يكفي أن يكون الثخص طفلا حتي يمارس الحق في الاستماع إلبه

في الخصومة المدنية، إنما يجب أن تثبت لدي هذا الطفل القدرة على التمبيز . تتص المادة Y I من اتفاقية حقوق الطفل تكفل الدول الأطر اف في هذه الاتفاقية للطفل القادر على تكوين آرائه الخاصة حق التعبير بحرية في جميع المسائل

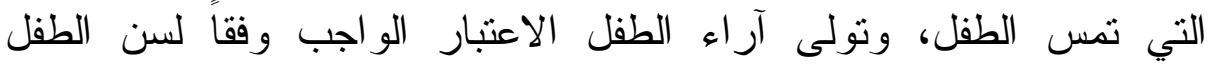
ونضجه. ولهذا الغرض، تتاح للطفل، بوجه خاص، فرصة الاستماع إلبه في أى إجر اعات قضائية و إدارية تمس الطفل، إما مباشرة أو من خلال ممثل أو هيئة ملأئم، بطريقة تثقق مع القو اعد الإجر ائية للقانون الوطني.

حيث عبرت هذه المادة عن شرط قدرة الطفل على التمبيز بعبارة أن يكون الطفل قادراً على تكوين آرائه الخاصة. فقدرة الطفل على تكوين آرائه الخاصة شرط أساسي لتمكين الطفل من الاستماع إلبه في الإجر اءات المتعلقة

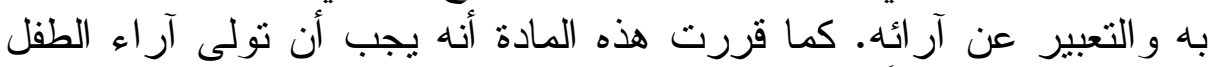

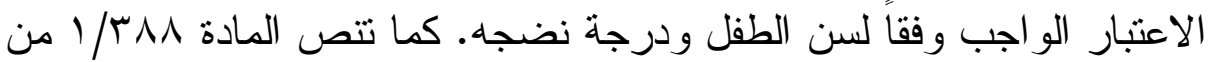
التقنين المدني الفرنسي على أنه في كل الإجراءات التي تتعلق به، القاصر القادر على التمبيز le mineur capable de discernement، بدون المساس بالقو اعد التي تتطلب تدخله أو رضائه، يمكن أن يستمع إلبه بو اسطة

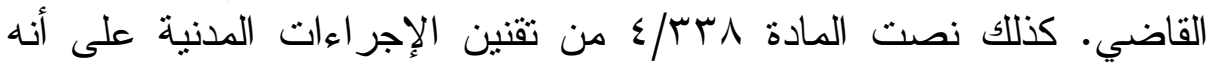

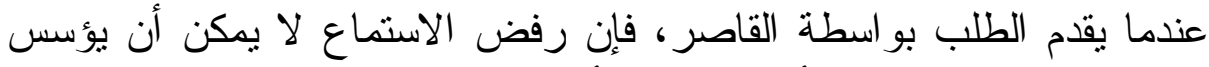

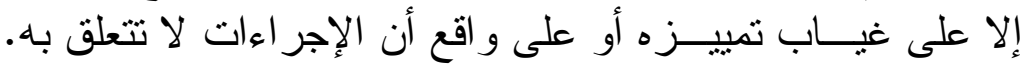

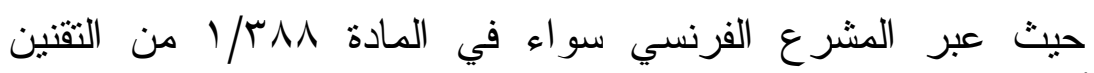
المدني أو في المادة رسب/ء من تقنين الإجراءات المدنية عن شرط قدرةٍ

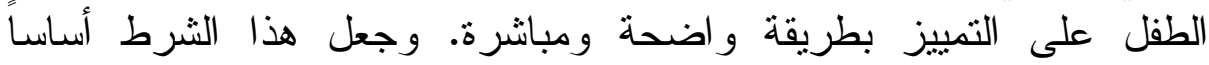

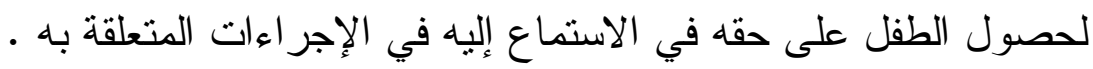

كما نصت المادة الثالثة من قانون الطفل المصري على أن يكفل هذا

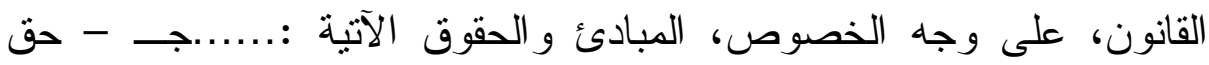
الطفل القادر على تكوين آرائه الخاصة في الحصول على المعلومات التي 


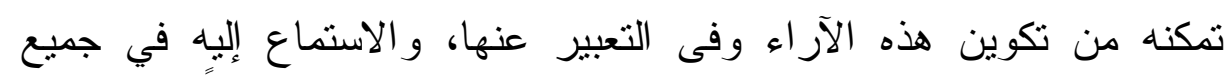

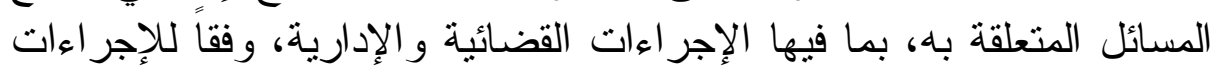

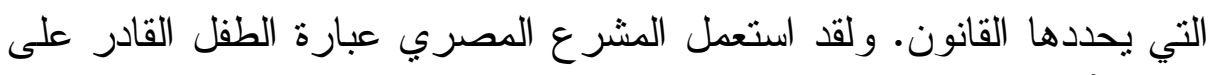

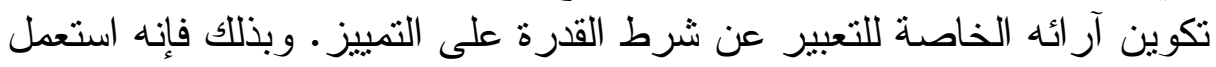

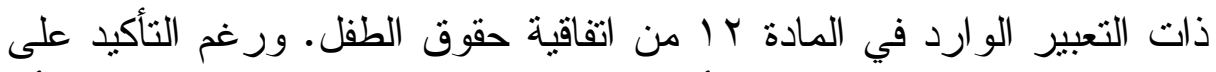

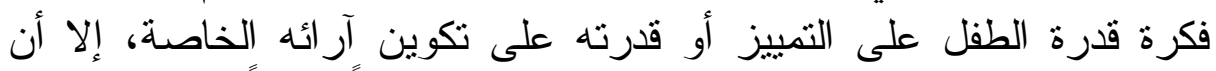

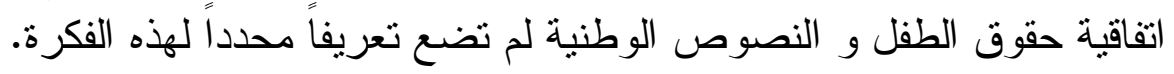
و إز اء غياب تعريف تشريعي لفكرة قدرة الطفل على التمبيز، فيجب

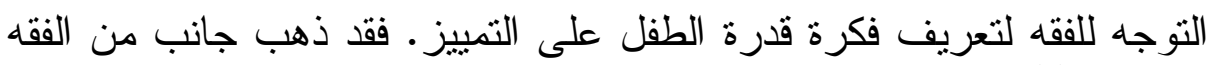

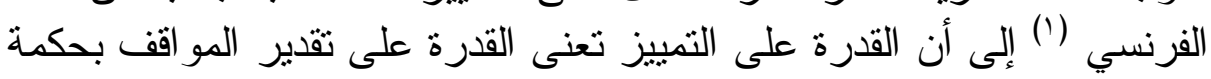
avec justesse

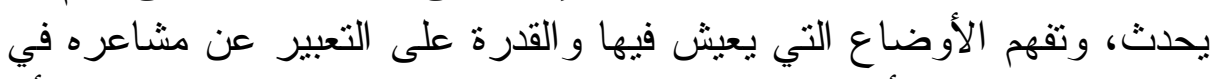

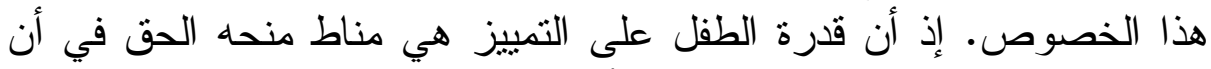

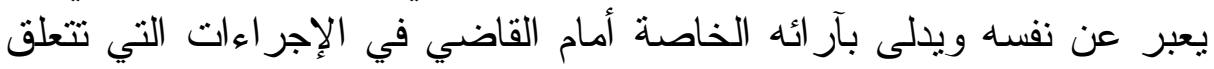

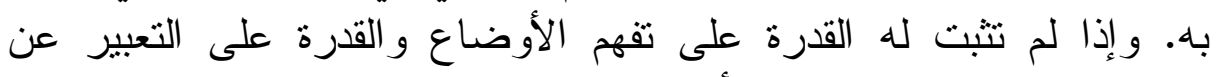

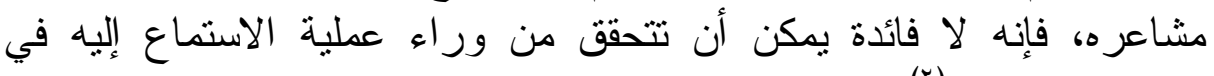

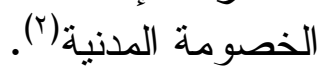

و على الجانب التطبيقي، نجد أن القضاء الفرنسي لجأ لعدة معايير

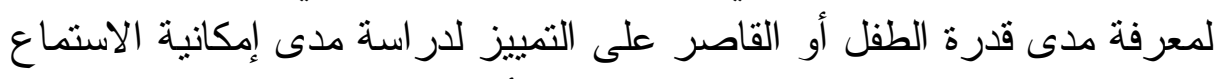

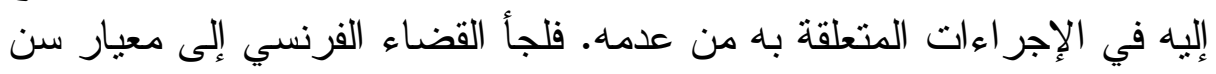

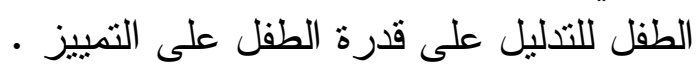

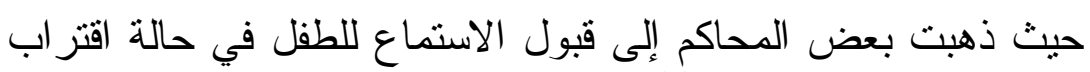

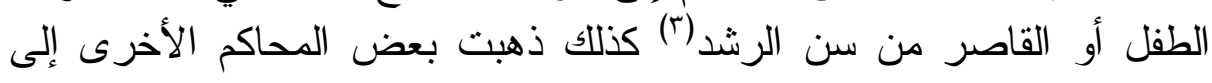

(1) C. Watine - Drouin, Audition du mineur en justice, op.cit. n 47, p.55.

(2) F. Alt-Maes, Le discernement et la parole du mineur en justice, JCP G, n 10, 6 Mars 1996, p. 3913.

(3) CA Douai, 6 févr. 2003 : JurisData ${ }^{\circ}$ 2003-244408. - d'un mineur de 16 ans, CA Riom, 28 mai 2002 : JurisData ${ }^{\circ} 2002-182369$. d'un mineur de 15 ans et 11 mois, CA Toulouse, 9 janv. 2007 : 


\section{عدم قبول الاستماع للأطفال في حالة صغر سن الطفل (').}

بالإضافة لمعيار سن الطفل للالالة على مدى قدرة الطفل على التمييز ، التهاء لجأ القضاء الفرنسي إلى معيار ذكاء الطفل ودرجة فهمه لتقدير شرط القاط القدرة

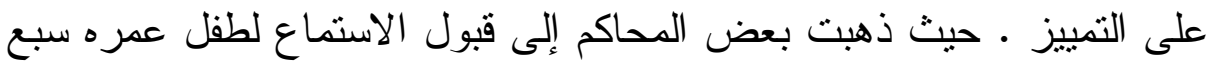

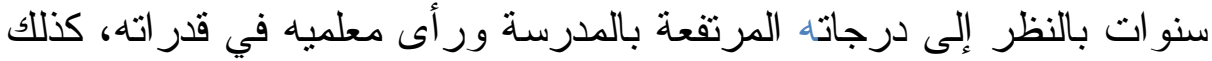

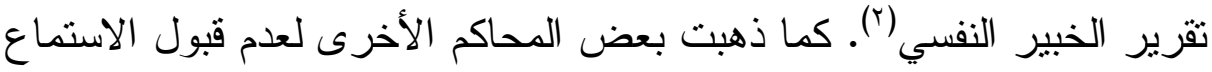

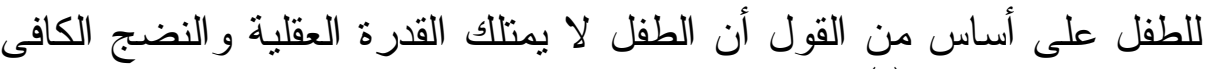

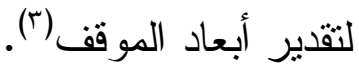

JurisData $n^{\circ}$ 2007-331142. - de mineurs de 15 et 12 ans, CA Aixen-Provence, 6 sept. 2007 : JurisData $n^{\circ}$ 2007-346051. - d'un mineur de 14 ans, CA Caen, 29 janv. s 2004 : JurisData ${ }^{\circ} 2004-$ 255684. - de mineurs 14 et 11 ans, CA Toulouse, 25 juin 2007 : JurisData $\mathrm{n}^{\circ}$ 2007-341309, V.sur site internete www.legifrance.com.

(1) CA Grenoble, 10 oct. 2007 : JurisData $n^{\circ}$ 2007-347952. d'enfants de 5 et 7 ans, CA Papeete, 20 sept. 2007 : JurisData $n^{\circ}$ 2007-345152. - d'enfants de 9 et 11 ans, CA Aix-en-Provence, 19 févr. 2004 : JurisData ${ }^{\circ}$ 2004-241913 ; CA Aix-en-Provence, 3 juill. 2002 : JurisData $\mathrm{n}^{\circ}$ 2002-195004. - d'un enfant pourtant proche de l'âge de raison, CA Toulouse, 21 avr. 1998 : JurisData $\mathrm{n}^{\circ}$ 1998-100787. - pour des décisions favorables à l'audition d'enfant de 11 ans, CA Bordeaux, 12 janv. 1999 : JurisData ${ }^{\circ}$ 1999-040167 ; CA Riom, 18 juill. 2000 : JurisData $\mathrm{n}^{\circ} 2000-$ 119303 ; CA Nancy, 23 juin 2003 : JurisData ${ }^{\circ}$ 2003-228527. d'un enfant de 9 ans, CA Paris, 14 oct. 1999 : JurisData $n^{\circ} 1999-$ 103817. - d'un enfant de 8 ans, CA Riom, 7 nov. 2000 : JurisData $\mathrm{n}^{\circ}$ 2000-127737. - d'un enfant de 7 ans, CA Paris, 7 févr. 2002 : JurisData $\quad \mathrm{n}^{\circ}$ 2002-167249). V.sur site internete www.legifrance.com.

(2) CA Aix-en-Provence, 8 déc. 2005 : JurisData $n^{\circ}$ 2005-299661, V.sur site internete www.legifrance.com.

(3) CA Rennes, 20 févr. 2006 : JurisData $n^{\circ}$ 2006-312694. - CA Angers, 30 nov. 2005 : JurisData $n^{\circ}$ 2005-293005, V.sur site internete www.legifrance.com. 


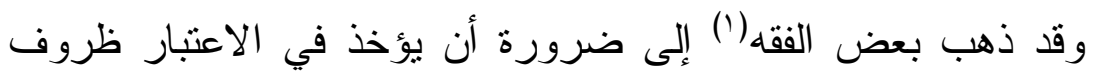

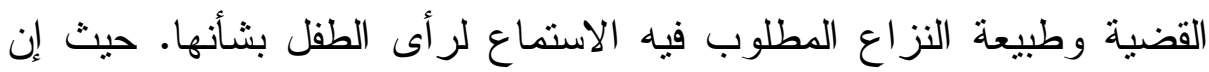

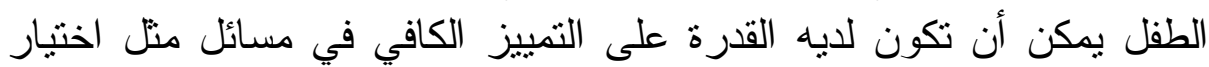

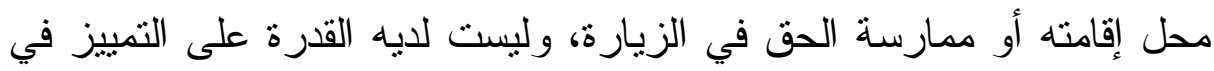

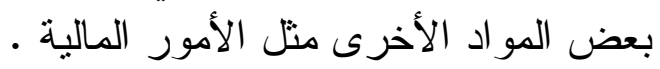

ويتم تقدير مدى قدرة الطفل على التمبيز بواسطة المحكمة التي تتظر

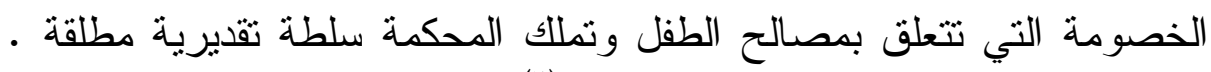
ويتم عادة هذا التقدير من خلال أسلوبين(r) الأول يتمنل في بحث المثل العناصر

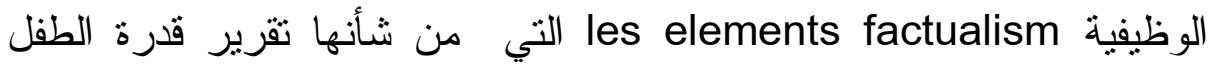
على التمييز بطريقة إيجابية، أما الثاني فيتمنل في أسلوب افتز اض قدرة الطفل

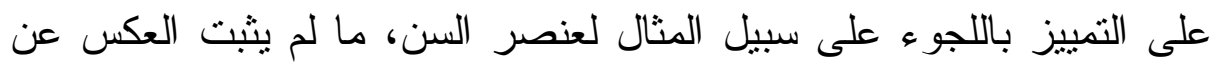

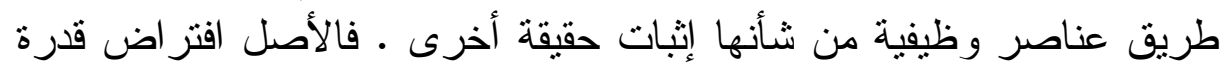
الطفل على التمييز ، ومن يدعى غير ذللك عليه إثبات العكس .

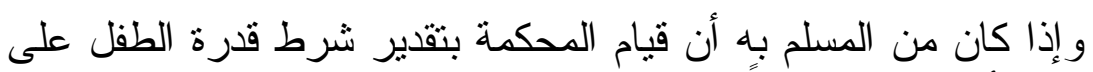

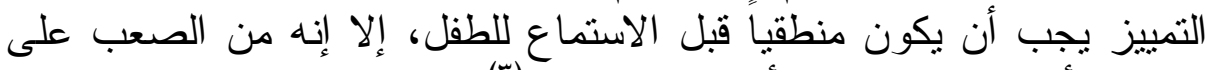

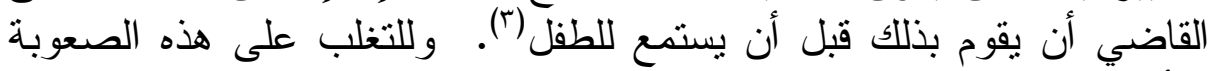

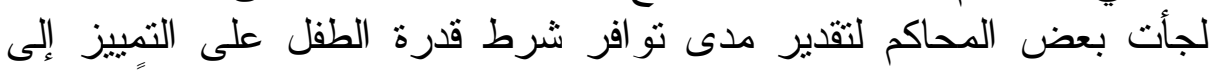

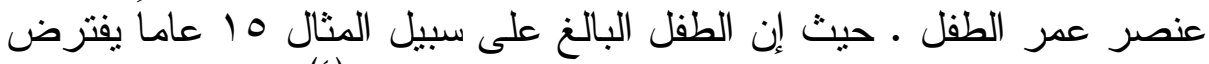

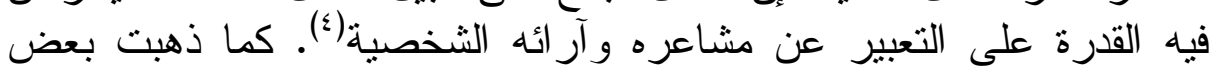
المحاكم الأخرى إلى الاعتماد على الأور اق المقدمة في الخصا التصومة التي يظهر

(1) $\mathrm{O} . \mathrm{M}$ atocq et $\mathrm{T}$. Dupré, La parole de l'enfant en justice après la convention de New York, in mélanges., D.Huet-Weiller: LGDJ 1994, p. 309.

(2) C. Watine- Drouin, audition du mineur en justice, op.cit. no 50, p.60.

(3) C.Neirinck, L'enfant el la procédure civil, LPA 3 mai, 1995, no 53, P. 77.J. Hauser, "Du discernement ou une famille réduite a la procédural, LPA, 28 avril 1999, No 84, P. 93.

(4) CA Aix-en province, 6 sep. 2007 : Juris date No 2007 - 346047, www.legifrance.fr. 
فيها قدرة الطفل على التمييز (1).

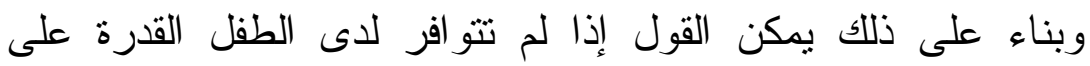
التمبيز فإنه لن يكون له الحق في الاستماع إلبه في الخصومة المدنية، فإذا تقدم بطلب إلى القاضي ليستمع إلبه في خصومة تنأثز فيها مصالحه، وقدر فئه القاضيي عدم القدرة على التمبيز من جانبه فان القرار الصادر من القاضي بعد قر اراً

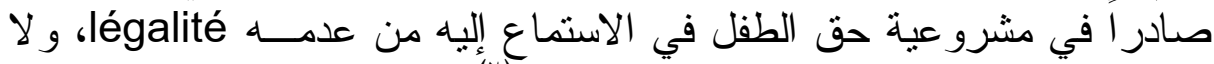

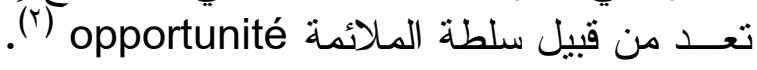

وقبل القانون الصادر في م مارس V . . . . كانت الصياغة الأصلية

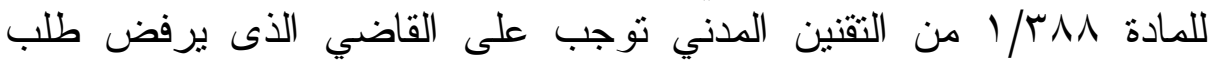

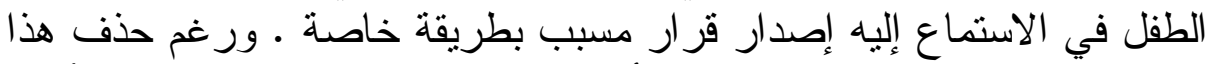

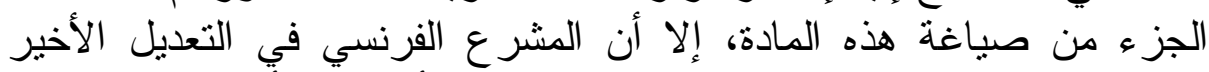

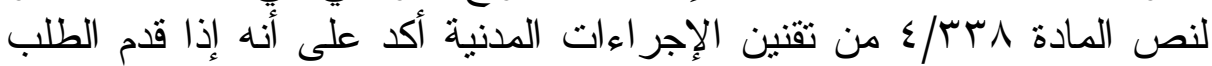

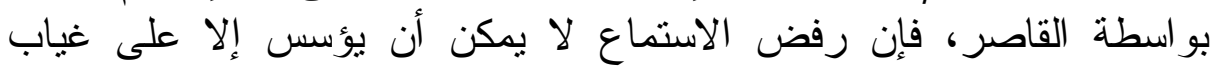

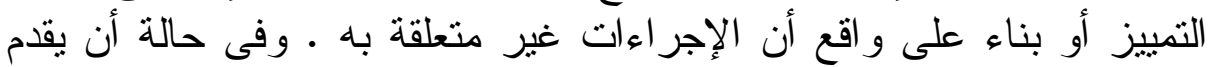

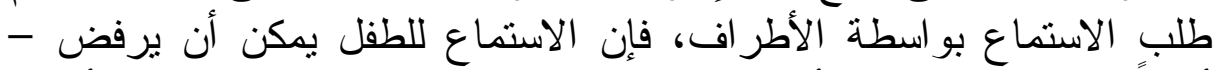

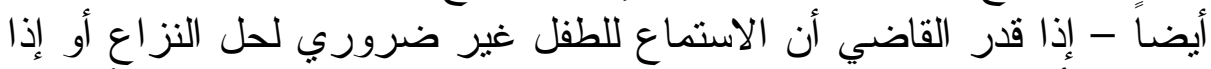

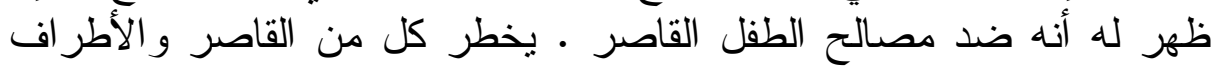

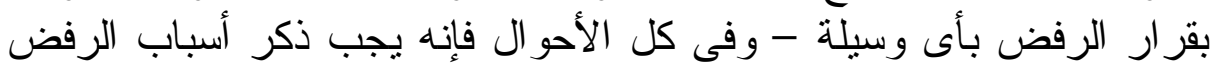

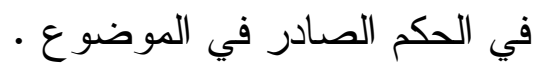

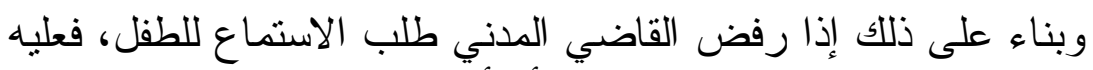
أن يؤسس رفضه سوِ اء على غياب التمييز أو أن الإجر اءات لا نتعلق بالطفل. ويجب عليه - أيضاً - أن يذكر ذلك صر احة في الحكم الصادر في موضوع

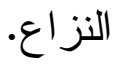

\section{المطلب الثاني}

\section{تعلق الخصومة المدنية بالطقل المستمع إليه}

بالإضافة إلى استلز ام أن يكون الطفل قادراً على التمييز لكى يثبت له له الحق في الاستماع إلبه، فإنه يجب إلى - كذلك - أن تكون الخصومة المدنية

(1) CA Montpellier, 6 Juin 1994 Juris-Data No 1994, 034187, www.legifrance.fr.

(2) C. Watine - Drouin, Audition du mineur en justice, op.cit. no 50, p.62. 
متعلقة بالطفل المستمع إليه. فإذا كانت الخصومة المدنية لا تتعلق به و لا تمسه فلا مجال للحديث عن حق الطفل في الاستماع اليه اليه.

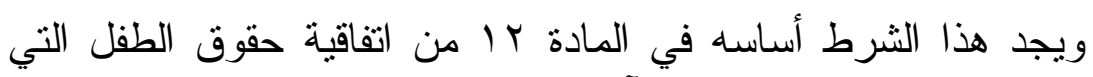

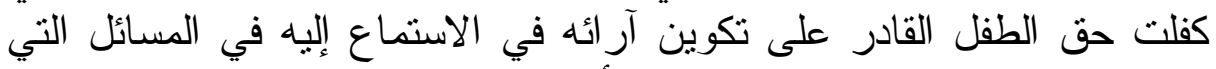

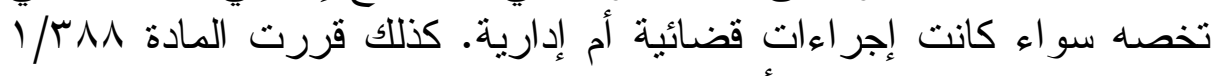

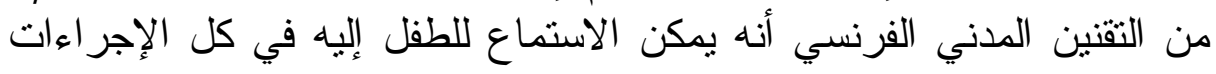

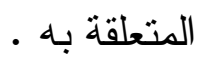

كما قررت المادة الثالثة من قانون الطفل المصري أن هذا القانون

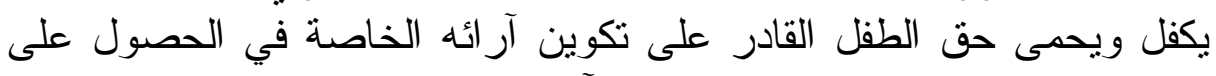

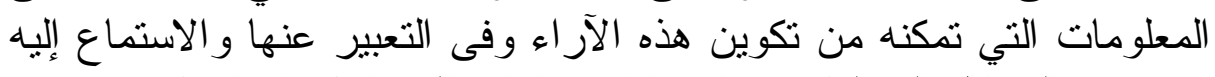
في جميع المسائل المتعلقة به بما فيها الإجر اءات القاء القضائية و الإدارية .

إلا أنه يثور تساؤل يتعلق بتحديد المعيار الذي بناء عليه يتم تحديد ما

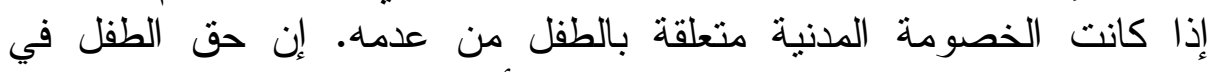

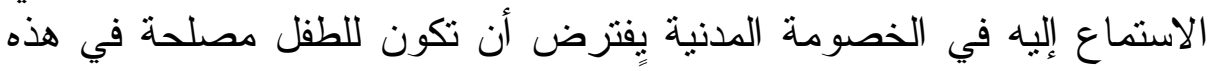

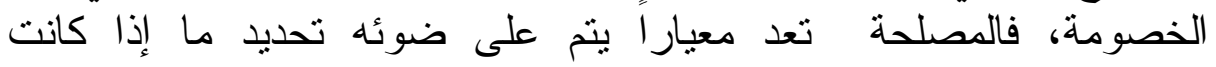

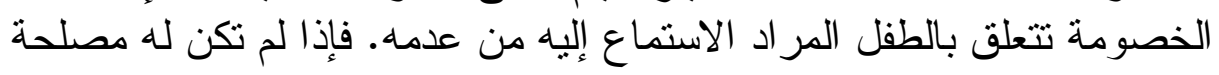

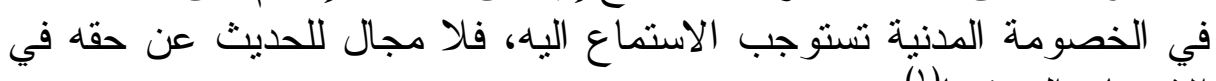

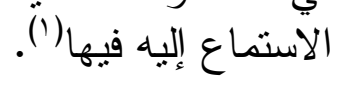

ونعتقد أن المقصود بالمصلحة في هذا الصدد هي تلك المصلحة

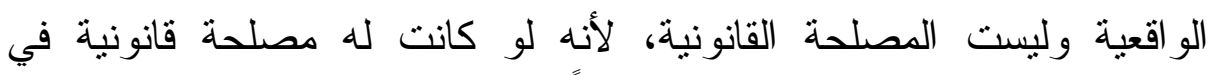

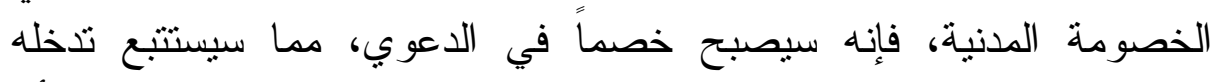

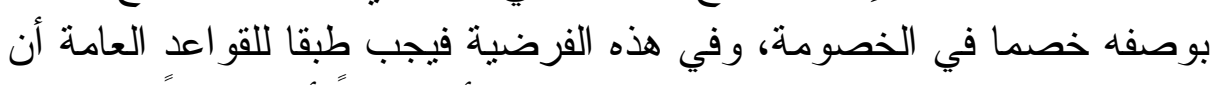

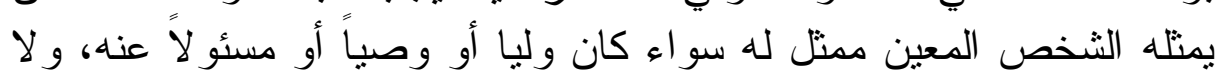

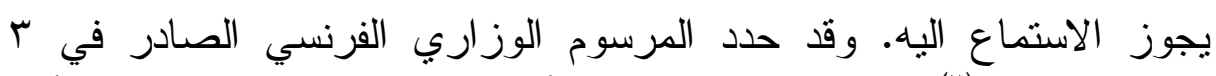

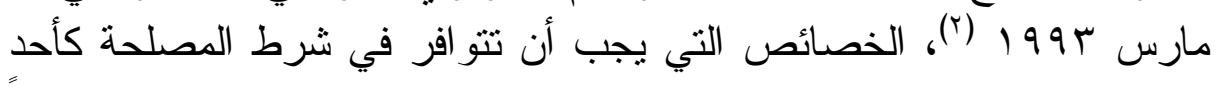

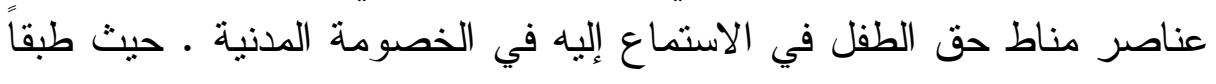

( ${ }^{1}$ J.-L. Viaux, Aspects psychologiques de la confrontation de l'enfant à la justice : Dr. famille 2006, p.359

(2) R. Martin, audition du mineur en justice, art. Precop.cit. no 32, p.39. 
لهذا المرسوم فإنه يجب أن تتوافر للطفل مصلحة شخصية personal

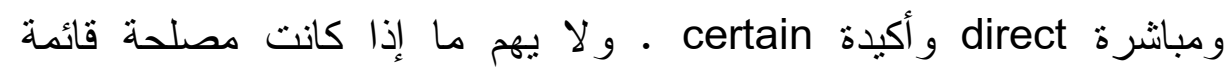

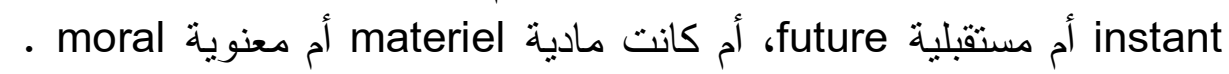
كذلك فإن محل الخصومة وظروف القضية يدخل في الاعتبار عند تحديد شرط مادية المصلحة.

ومن الجدير بالذكر أن الطفل لا تتبت له مصلحة مباشرة وشخصية

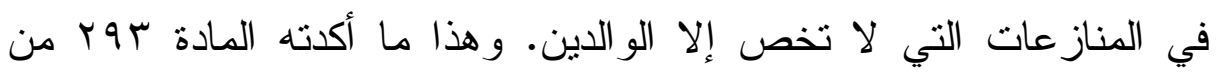
التقنين المدني الفرنسي و التي قررت أنه لا يقبل الاستماع للأطفال في الأسانيد

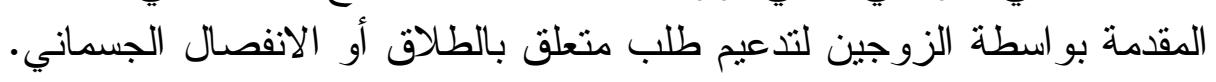

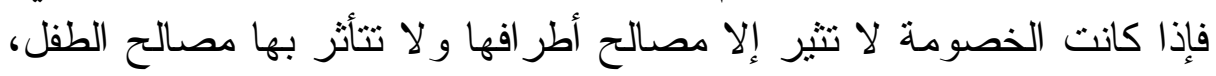

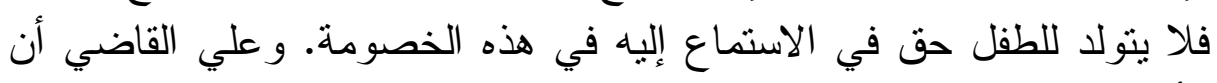

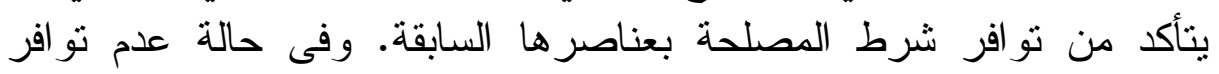

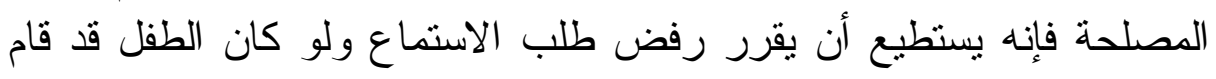

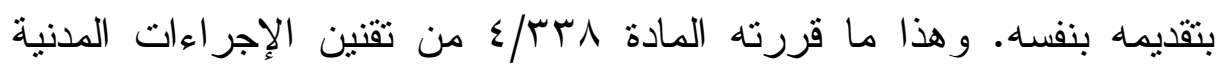

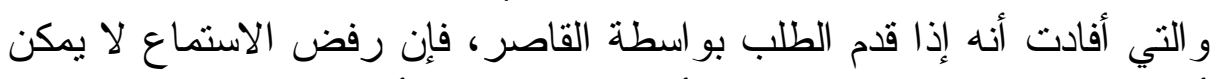

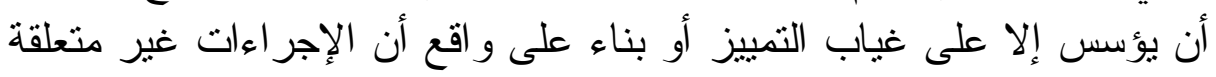

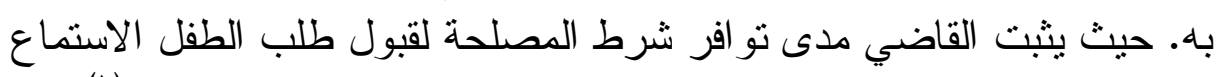

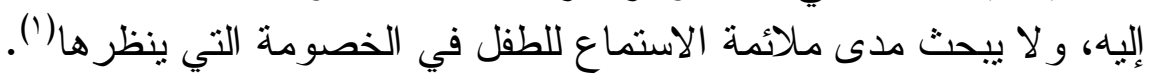

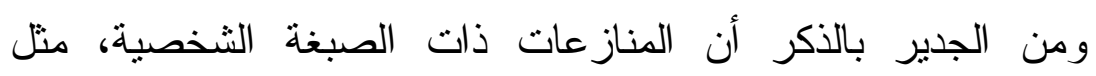

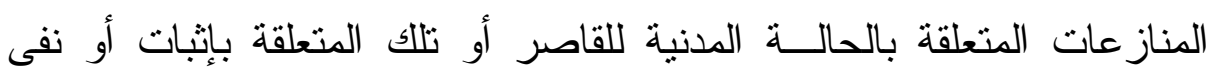

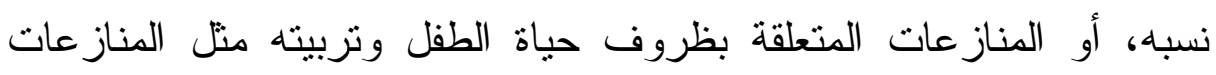
المتعلقة بإقامته أو بحقه في الزيارة في حالة طلاق الوالو الدين - من أكثر

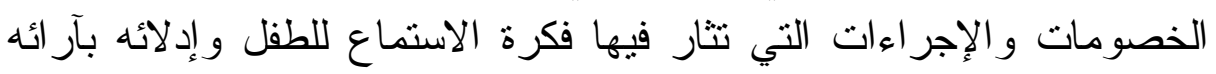

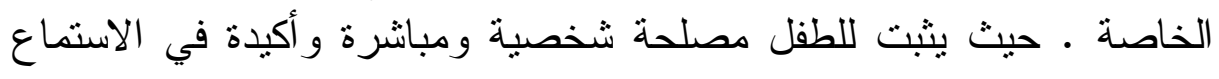

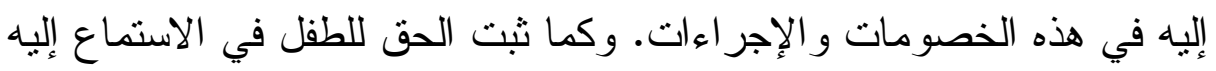

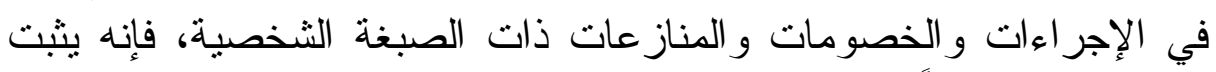

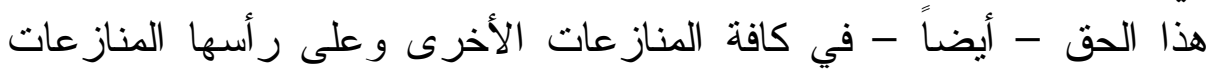

(1) C. Watine - Drouin, audition dumineur en justice, op.cit. no 53, p. 68 . 


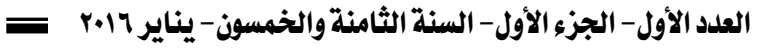

\section{و الخصومات المالية' .}

وتذهب السيدة Marie-Pierre Baudin-Maurin 'إلى ضرورة قصر

الاستماع للطفل على المنازعات المتعلقة بشخصية الطفل دون أمواله. وذللك على اعتبار أن ذلك التفسير بتتاسب مع مفهوم فكرة الاستماع للطفل بحسب الاب الاتفاقية الدولية لحماية حقوق الطفل، و الذي بعتمد على ضرورة الاستماع للطفل في الإجر اءات التي تتعلق به وليس تلك المتعلقة بأمو اله.

(1) B. Kan-Balivet, Audition du mineur en justice, JurisClasseur Encyclopédie des Huissiers de Justice, 2013, Fasc.10, n 18, P.32.

(2) M.-P. Baudin-Maurin, Audition du mineur à sa demande : réflexion inspirée par la jurisprudence, LPA, 21 juin $2013 n^{\circ}$ 124, P. 4. 


\section{الفصل الثاني \\ الإطار الإجر ائي لممارسة الطفل حقه \\ في الاستماع إليه في الخصومة المدنية}

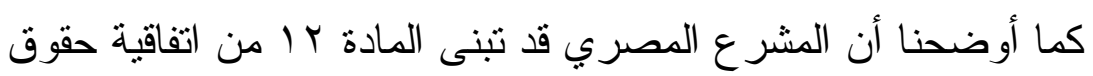

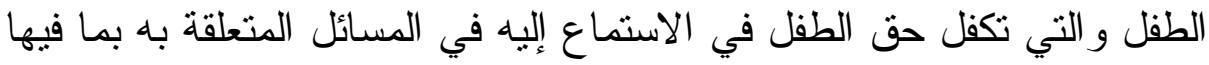

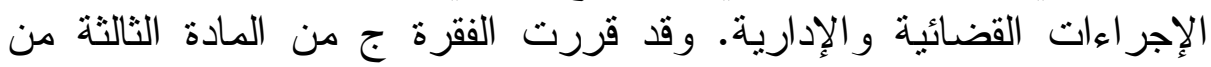

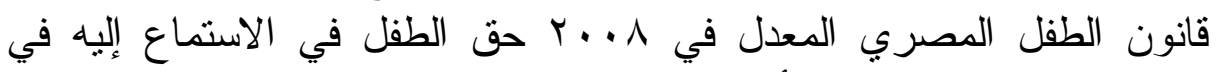

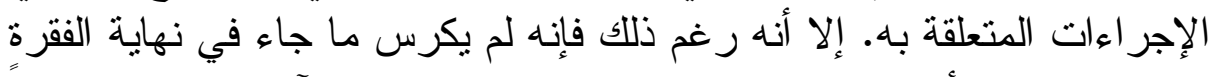

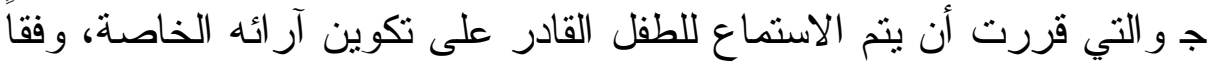

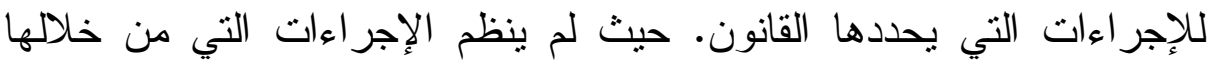

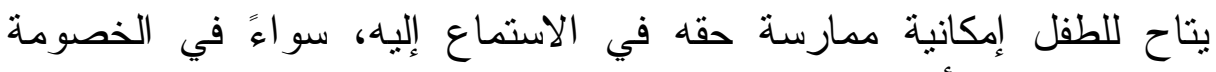
القضائية المدنية أم غير ها.

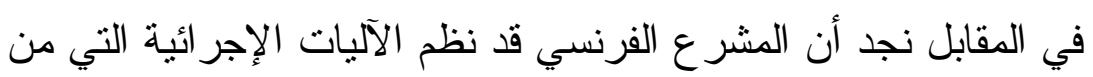

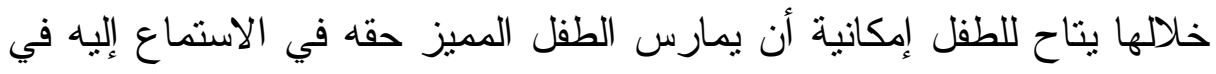
الخصومة المدنية المتعلقة به. فقد نظم المشرع المارع الفرنسي الإطار الإجرائي

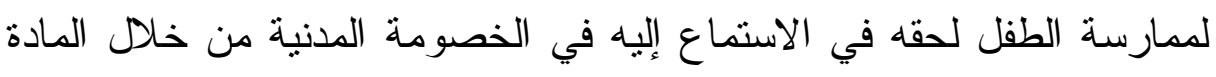

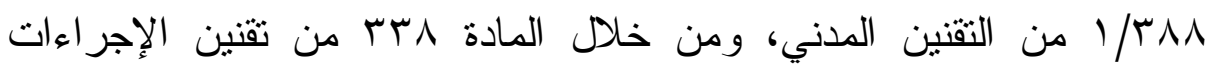
المدنية في الفقرة الأولى حنى الفقرة الثانية عشرة لمنها.

أمام ذللك، فإننا سنعالج الإطار الإجرائي لممارسة الطفل حقه في

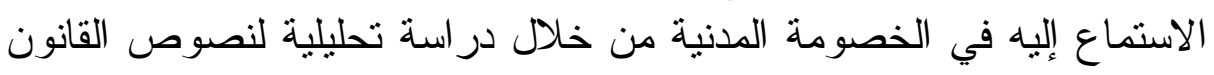

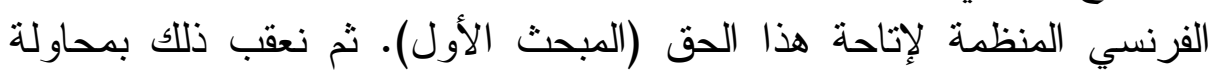

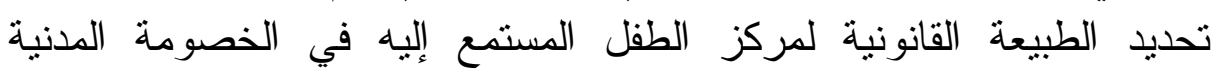

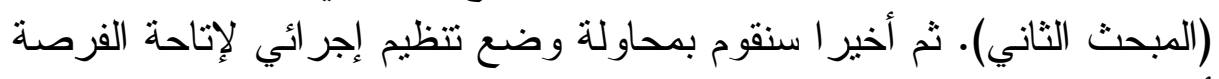
أمام الطفل المميز لممارسة حقه في الاستماع إليه(المبحث الثنالث). 


\section{المبحث الأول}

التنظيم الإجرائي الفرنسي لإتاحة الفرصة أمام الطقل المميز

\section{ليمارس حقه في الاستماع إليه في الخصومة المدنية}

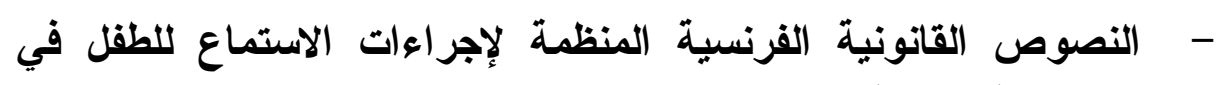

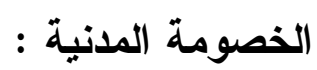

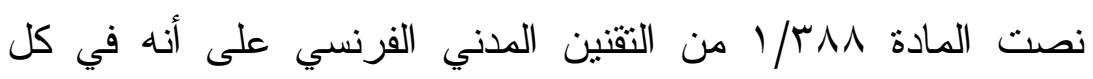

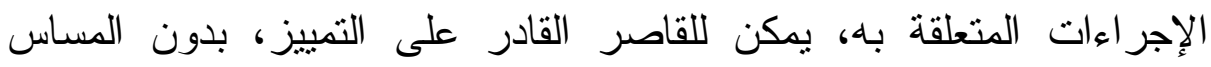

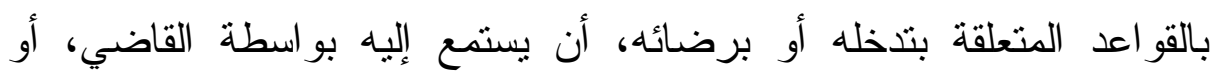

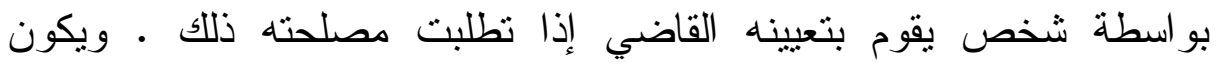

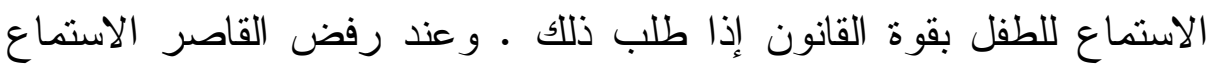
إليه، يقوم القاضي بتقدير أساس هذا الرفض. ويمكن الاستماع للطفل بمفرده

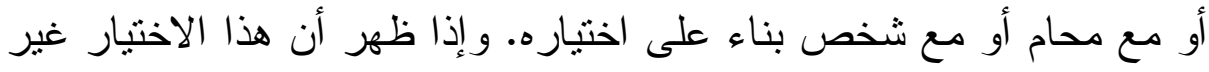

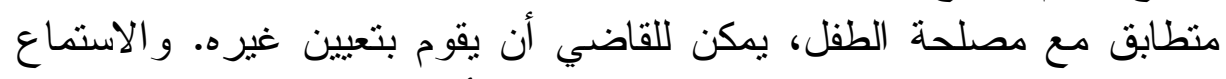
للطفل لا يمنحه صفة الطرف بالإجر اءات. ويتأكد القاضي من إعلام الطفل بحقه في الاستماع إليه وحقه في مساعدة أحد المحامين ('). كذلك نصت المادة مبس بفقر اتها الاثتي عشرة على الآتي :-

$\left({ }^{1}\right)$ Dans toute procédure le concernant, le mineur capable de discernement peut, sans préjudice des dispositions prévoyant son intervention ou son consentement, être entendu par le juge ou, lorsque son intérêt le commande, par la personne désignée par le juge à cet effet.Cette audition est de droit lorsque le mineur en fait la demande. Lorsque le mineur refuse d'être entendu, le juge apprécie le bien-fondé de ce refus. Il peut être entendu seul, avec un avocat ou une personne de son choix. Si ce choix n'apparaît pas conforme à l'intérêt du mineur, le juge peut procéder à la désignation d'une autre personne.L'audition du mineur ne lui confère pas la qualité de partie à la procédure.Le juge s'assure que le mineur a été informé de son droit à être entendu et à être assisté par un avocat. 
الفقرة الأولى ('): تتص هذه الفقرة على أن القاصر القادر على التمييز

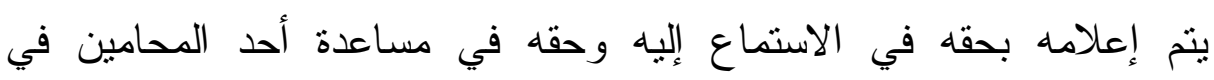

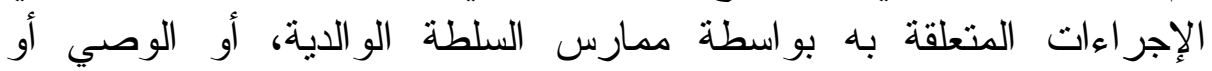

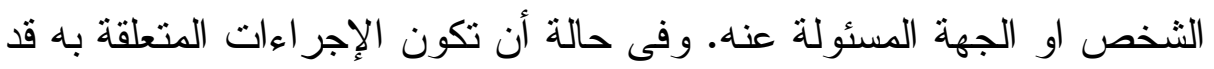

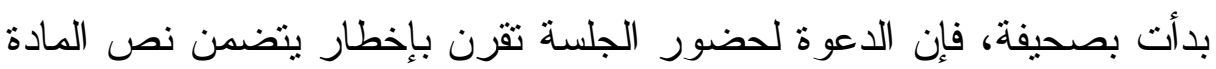

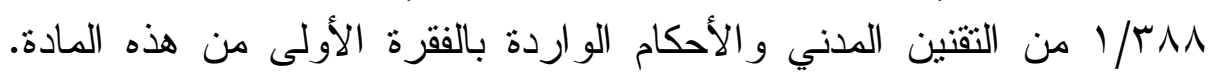

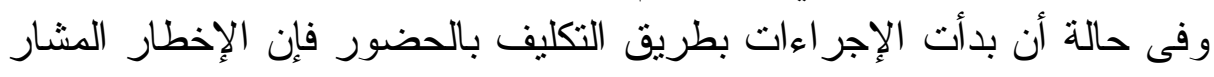

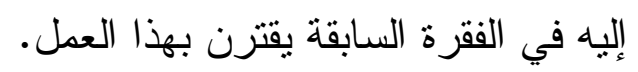

وتتص الفقرة الثانية(r) من هذه المادة على أن طلب الاستماع يقدم

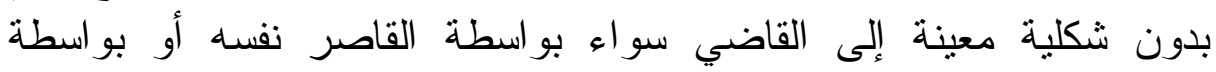
الأطر اف. ويمكن أن يكون في أى حالة تكون عليها الإجر اءات، ولو لأول مرة أمام محكمة الاستئناف.

وتتص الفقرة الثالثة (ץ) على أن القرار الصادر بالاستماع للطفل يمكن أن يؤشر به بملف الدعوي أو تسجيله بمحضر الجلسة.

Le mineur capable de discernement est informé par le ou les (') titulaires de l'exercice de l'autorité parentale, le tuteur ou, le cas échéant, par la personne ou le service à qui il a été confié de son droit à être entendu et à être assisté d'un avocat dans toutes les procédures le concernant. Lorsque la procédure est introduite par requête, la convocation à l'audience est accompagnée d'un avis rappelant les dispositions de l'article 388-1 du code civil et celles du premier alinéa du présent article. Lorsque la procédure est introduite par acte d'huissier, l'avis mentionné à l'alinéa précédent est joint à celui-ci.

$\left(^{2}\right)$ La demande d'audition est présentée sans forme au juge par le mineur lui-même ou par les parties. Elle peut l'être en tout état de la procédure et même pour la première fois en cause d'appel

$\left(^{3}\right)$ La décision ordonnant l'audition peut revêtir la forme d'une simple mention au dossier ou au registre d'audience. 
وتتص الفقرة الر ابعة(') على أنه عندما يقدم الطلب بواسطة القاصر

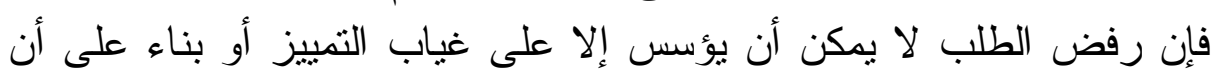

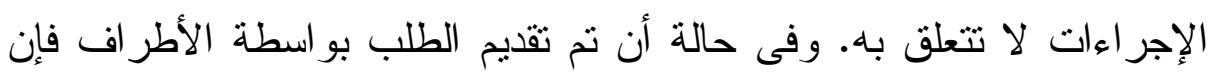

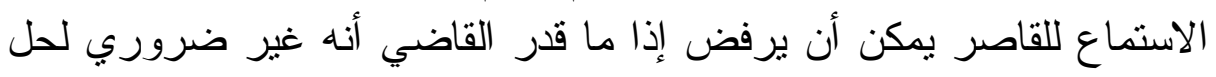

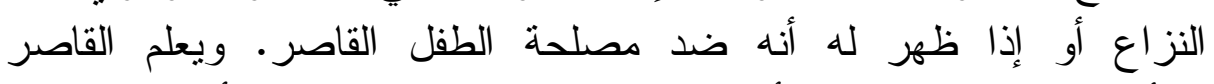

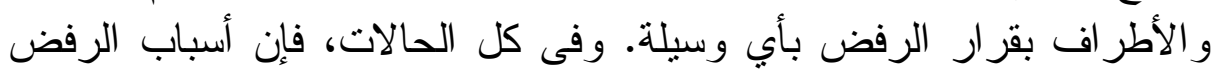

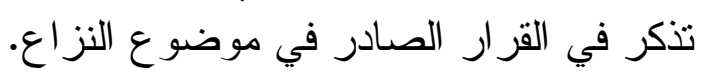

وتتص الفقرة الخامسة(؟) من هذه المادة على أن القرار الصادر في

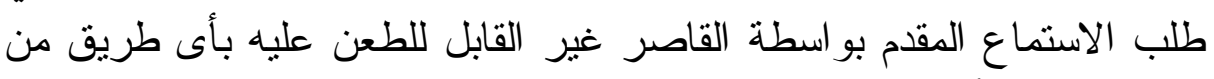

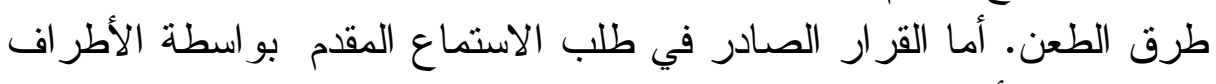

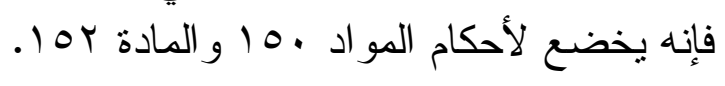

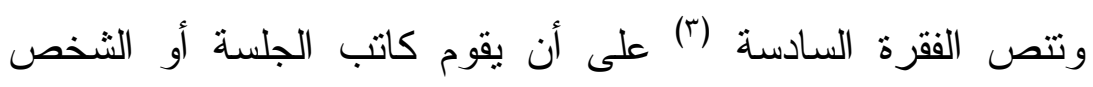

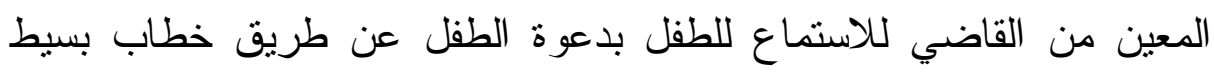

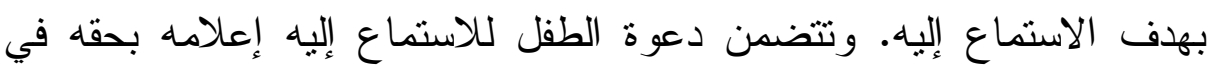

( $\left.{ }^{1}\right)$ Lorsque la demande est formée par le mineur, le refus d'audition ne peut être fondé que sur son absence de discernement ou sur le fait que la procédure ne le concerne pas. Lorsque la demande est formée par les parties, l'audition peut également être refusée si le juge ne l'estime pas nécessaire à la solution du litige ou si elle lui paraît contraire à l'intérêt de l'enfant mineur. Le mineur et les parties sont avisés du refus par tout moyen. Dans tous les cas, les motifs du refus sont mentionnés dans la décision au fond.

( ${ }^{2}$ La décision statuant sur la demande d'audition formée par le mineur n'est susceptible d'aucun recours. La décision statuant sur la demande d'audition formée par les parties est soumise aux dispositions des articles 150 et 152.

$\left({ }^{3}\right)$ Le greffe ou, le cas échéant, la personne désignée par le juge pour entendre le mineur adresse à celui-ci, par lettre simple, une convocation en vue de son audition. La convocation l'informe de son droit à être entendu seul, avec un avocat ou une personne de son choix. Le même jour, les défenseurs des parties et, à défaut, les parties elles-mêmes sont avisés des modalités de l'audition 


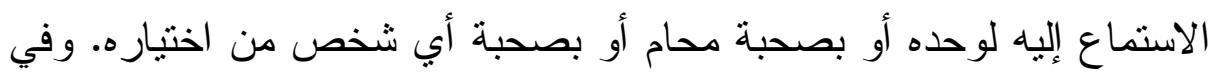

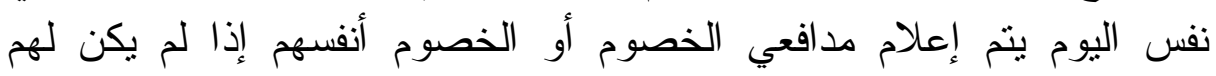
مدافعين بألية الاستماع للطفل.

وتتص الفقرة السابعة(1) على أنه إذا طلب القاصر الاستماع إليه

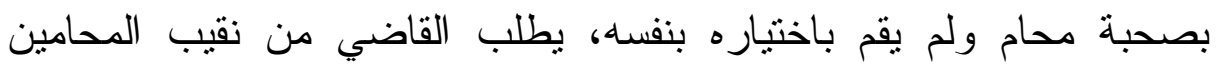

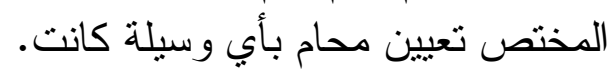

وتتص الفقرة الثامنة(r) على أنه في حالة أن يقرر الاستماع للقاصر

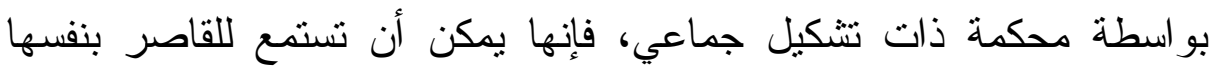
ويمكن لها أن تقوم بتعيين أحد من أعضائها لإجر ائها ويُحرر محضرُ بذئل بذلك.

وتتص الفقرة التاسعة على أنه في حالة أن يقدر القاضي أن مصلحة

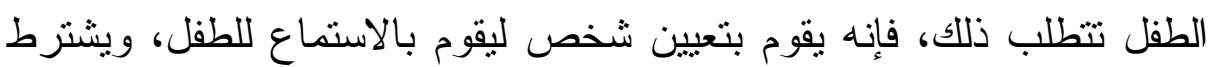

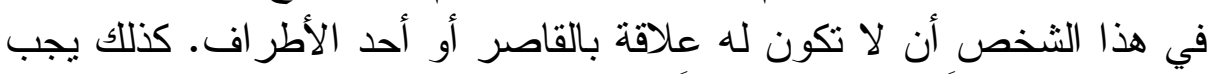

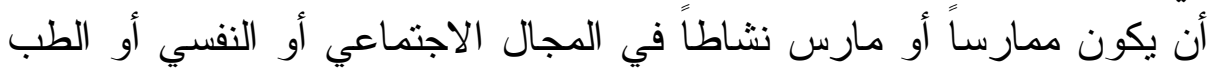

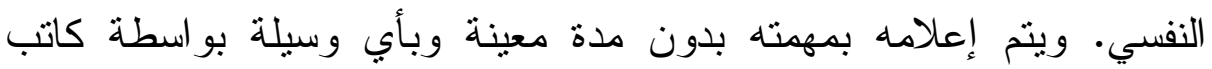

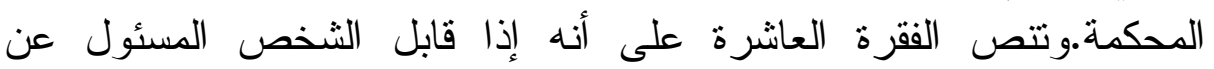
الاستماع للقاصر صعوبات معينة، فإنه يلجأ للقاضي بدون الفي ميعاد معين.

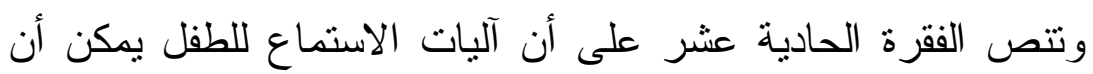

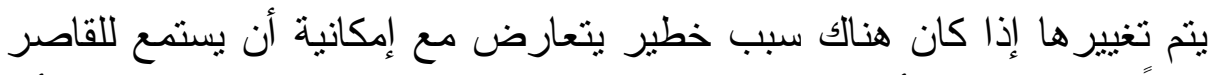
طبقاً لما هو مقرر أصلا. وتتص الفقرة الثانية عشرة من ذاك ذات المادة على ألى أنه

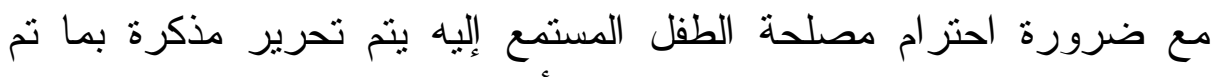
بجلسة الاستماع، وتخضع هذه المذكرة لمبدأ المو اجهة.

و علي ضوء هذه النصوص فإننا سنقوم باستعر اض النتظيم الإجرائي

(1) Si le mineur demande à être entendu avec un avocat et s'il ne choisit pas lui-même celui-ci, le juge requiert, par tout moyen, la désignation d'un avocat par le bâtonnier.

$\left.{ }^{2}\right)$ Lorsque l'audition est ordonnée par une formation collégiale, celleci peut entendre elle-même le mineur ou désigner l'un de ses membres pour procéder à l'audition et lui en rendre compte 
الفرنسي لإتاحة الفرصة أمام الطفل لممارسة حقه في الاستماع إليه في

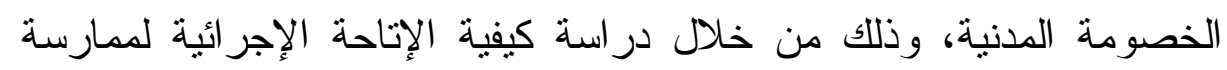

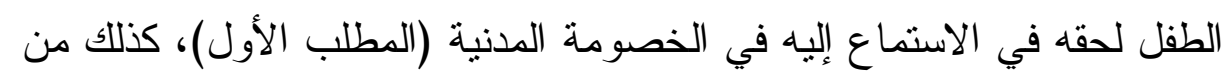

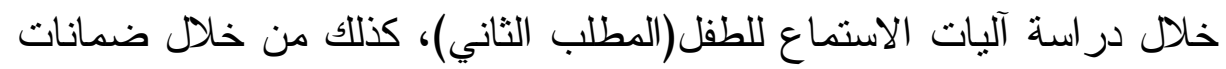

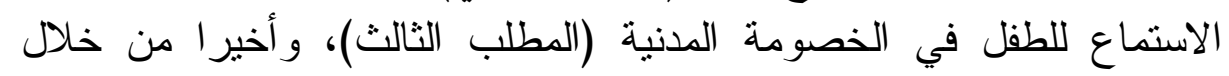
تحديد القيمة القانونية لأقو ال الطفل لدى المحكمة المطلب المدنة الر ابع).

\section{المطلب الأول}

\section{الإتاحة الإجرائية لممارسة الطقل حقه \\ في الاستماع إليه في الخصومة المدنية}

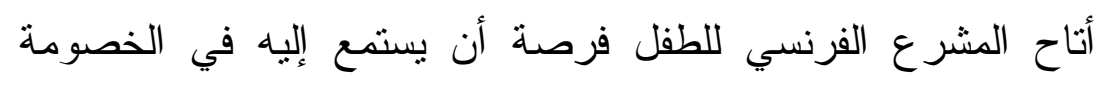

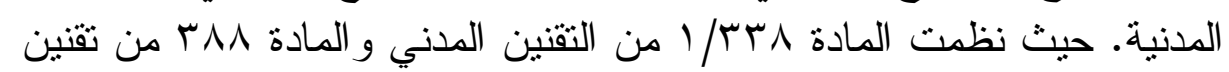

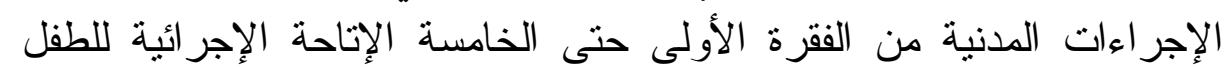
ليمارس حقه في التعبير عن رأيه في النزاع الأع محل الخصني الخصومة المتعلقة به.

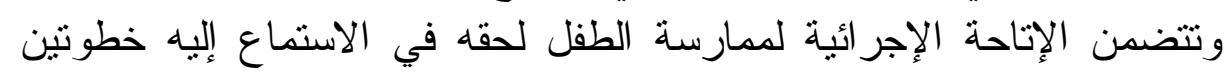

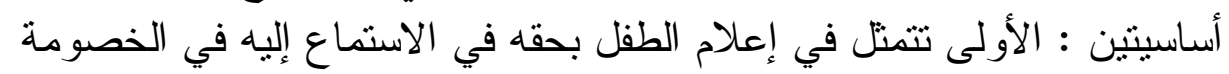

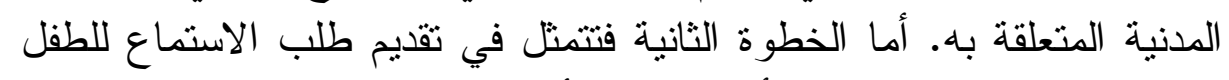

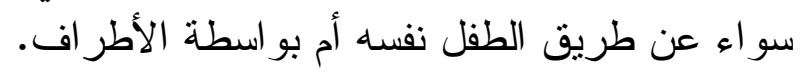

\section{الفرع الأول}

\section{إعلام الطقل بحقه في الاستماع إليه في الخصومة المدنية المتعلقة به اله}

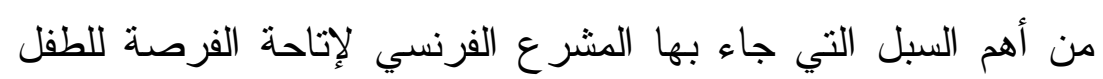

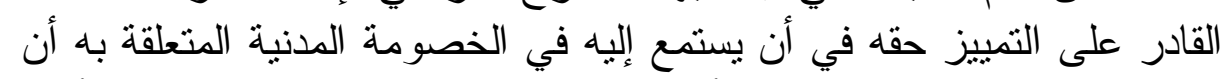

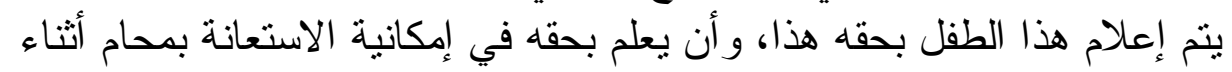

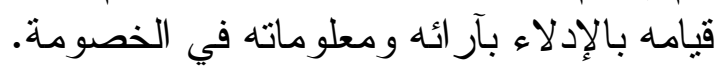

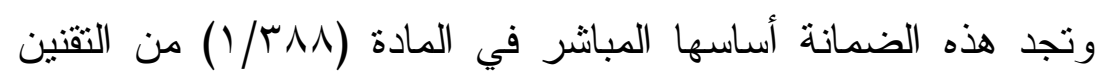

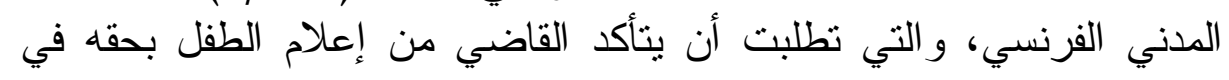
الاستماع إليه وحقه في الاستعانة بمحام.

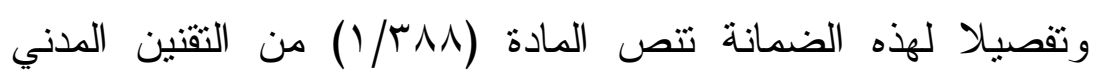

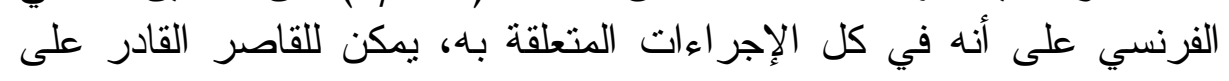

=V9 
التمييز، بدون المساس بالقو اعد المتعلقة بتذخله أو برضائه، أن يستمع إليه

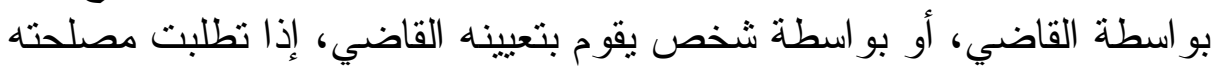

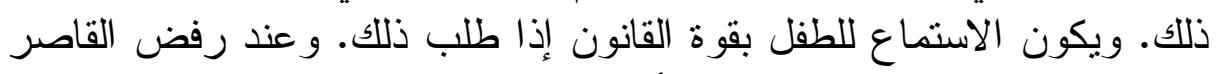

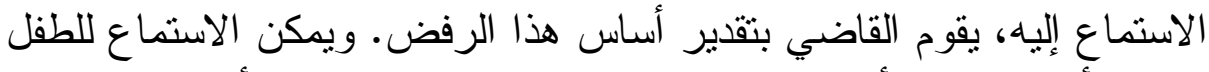

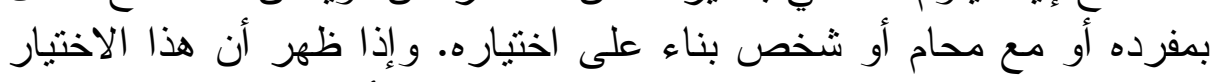

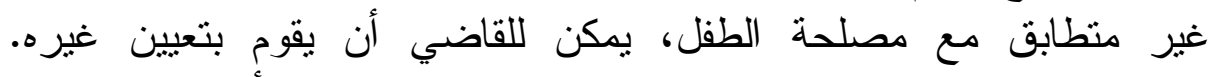

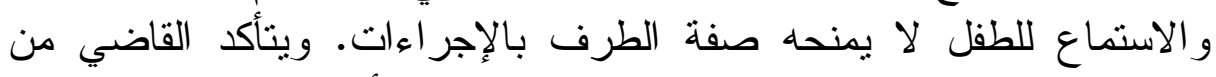
إعلام الطفل بحقه في الاستماع إليه وحقه في مساعدة أحد المحامين.

وجاءت المادة (رس// ( ) من تقنين الإجراءات المدنية لتوضح كيفية

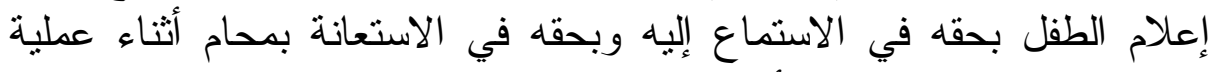

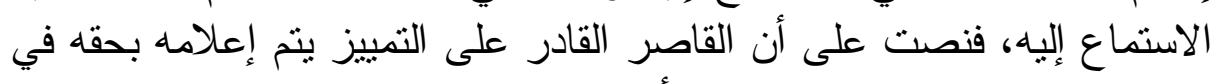

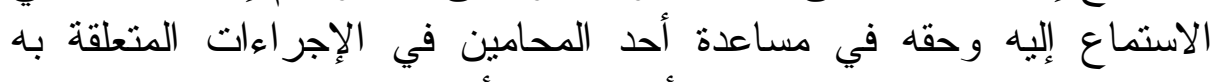

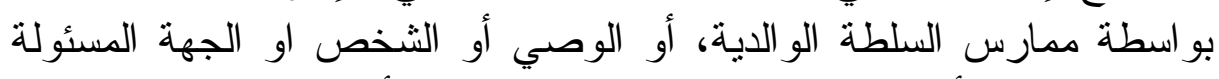

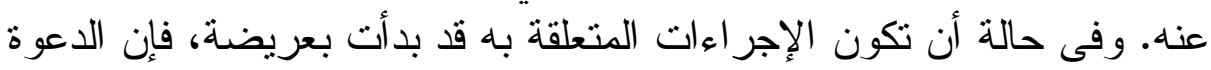

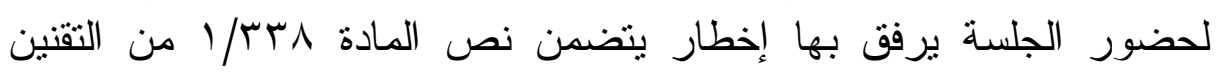

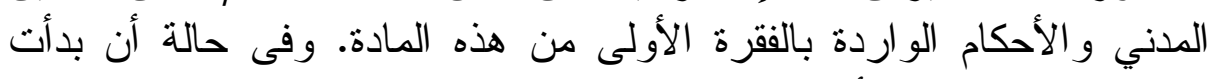

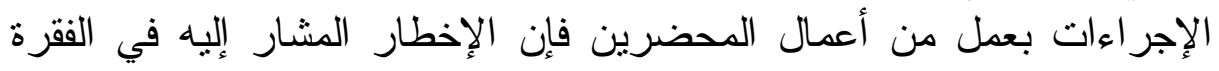

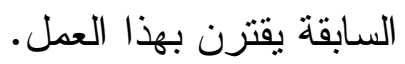

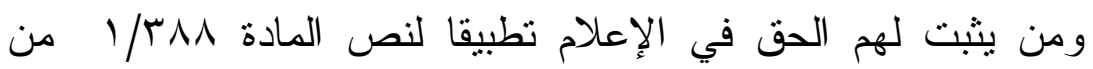
التقيين المدني الفرنسي هم القصر القادرون على التمييز. وبمفهوم المخالفة فإن القصر غير المميزين لا يلتزم الأشخاص المنصوص لفئ عليهم في هذه المادة

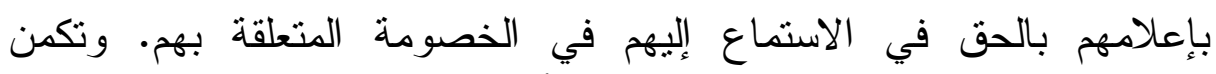

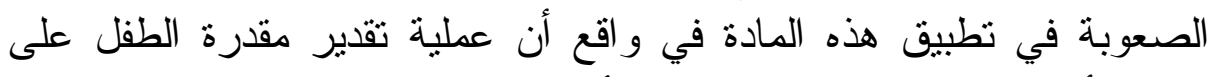

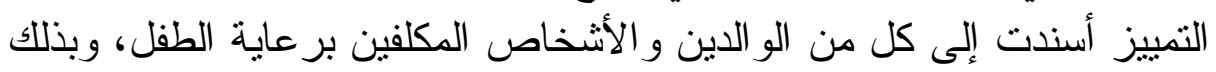

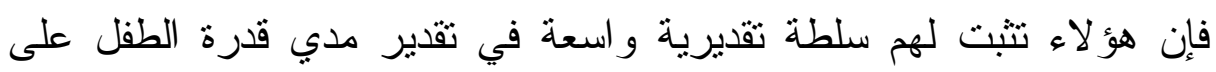

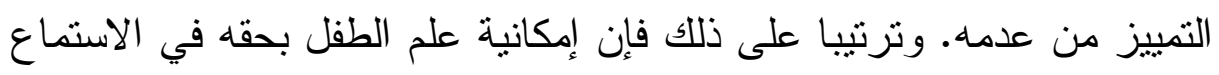
إليه في الإجر اءات المتعلقة به معلقه على تقدير هؤلاء، إذ يستطيعون تقرير 
عدم قدرة الطفل على التمبيز، وبالتالي عدم التزامهم بإعلامه على هذا

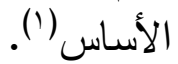

ويقع الالتز ام بإعلام الطفل القادر على التمبيز بحقه في الاستماع إليه

وحقه في الاستعانة بمحام على عاتق أثخاص حددهم المشرع الفراعلى الفرنسي على الفى

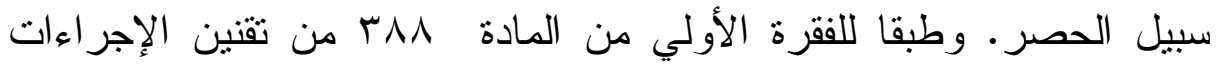

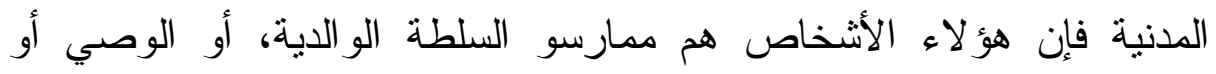
الثخص أو الجهة المسئولة عنه. حيث ألزم المشرع اهن من تقع عليهم مسئولية

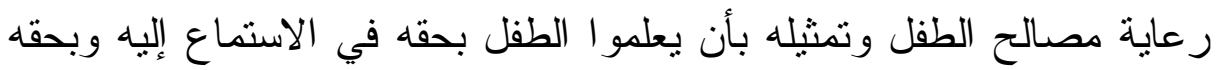
في الاستعانة بمحام.

وقد ألزم المشرع الخصم الذي يباثر إجر اءات دعوي تتعلق بمصالح

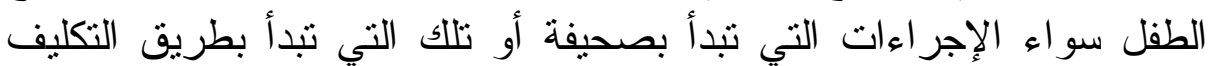

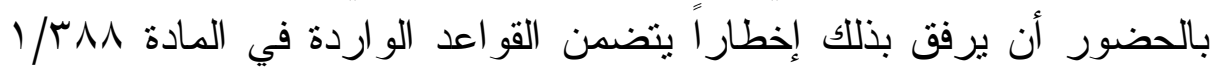

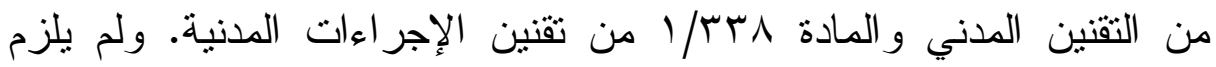

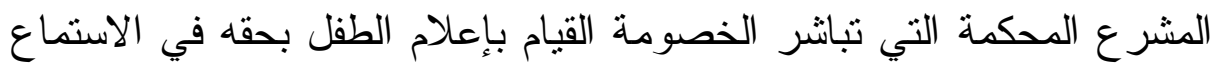

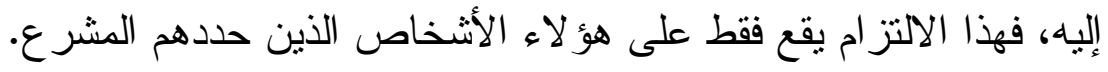

وقد انتقد بعض من الفقه ما ذهب إليه المشرع الفرنسي من عدم إلزام

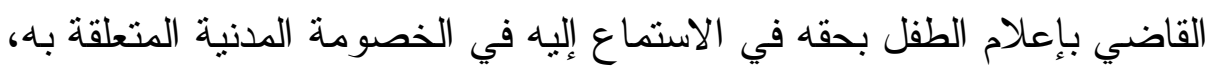

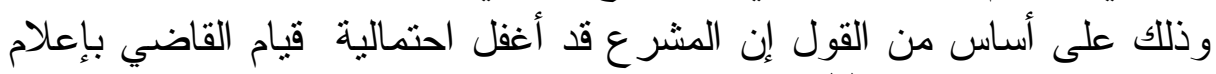

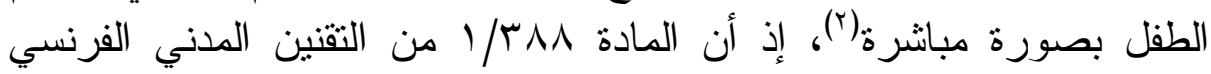

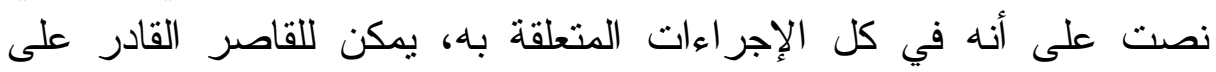

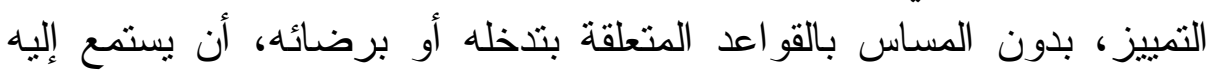

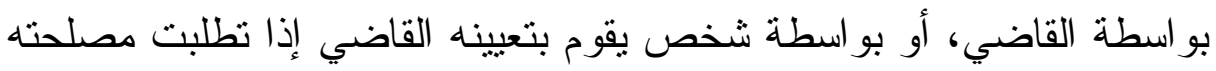

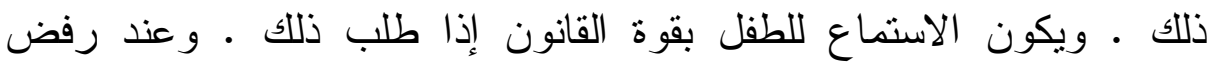
الاستماع إليه، يقوم القاضي بتقدير أساس هذا الرفض. لوض ويمكن الاستماع للطفل

(1) J.Raphael-Demarchi, Une justice familiale en mutation, Bilan de l'evolution legislative relative a l'audition de l'enfant, LPA, 17 mas 2010, n 54, .p.3 .

(2) L .François- Terminal, Le nouveau régime de l'audition en justice de l'enfant concerne par une procédure judicaire, Rev. Dr . famille, September 2009 , n 13 . 
بمفرده أو مع محام أو شخص بناء على اختياره. و إذا ظهر أن هذا الاختيار

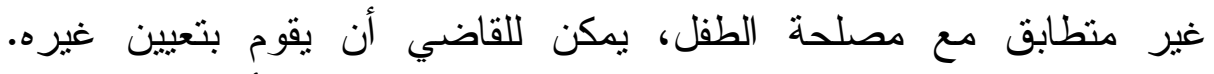

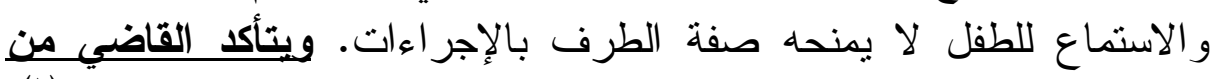
إعلام الطقل بحقه في الاستماع إلبه وحقه في مساعدة أحد المحامين (').

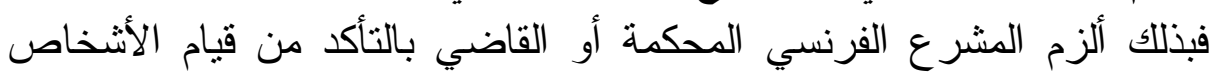

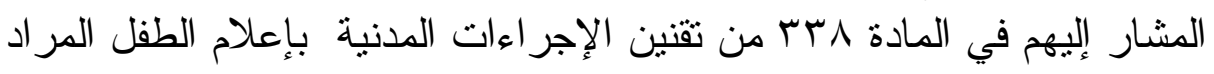

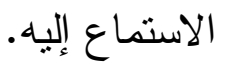

\section{الفرع الثاني \\ طلب الاستماع للطقل في الخصومة المدنية}

تتص المادة MA من التقبين المدني على أنه " في كل الإجراءات

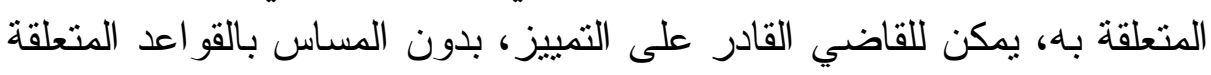

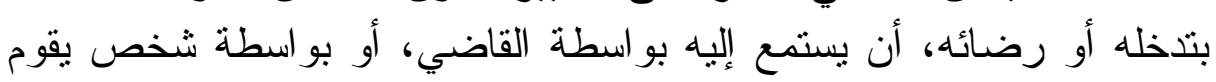

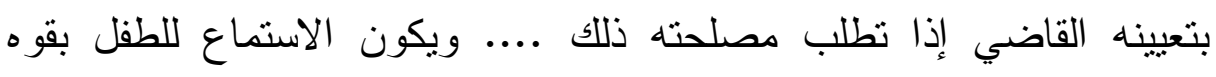

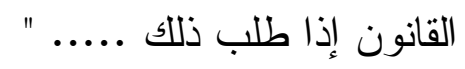

كذلك نصت الفقرة الثانية من المادة مبr من تقيين الإجر اءات المدنية

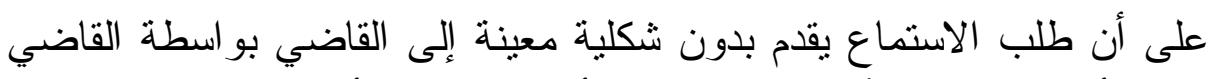

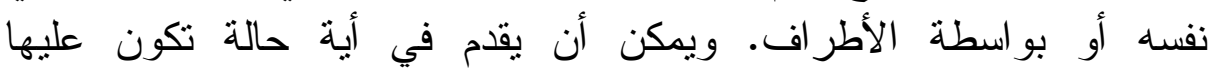

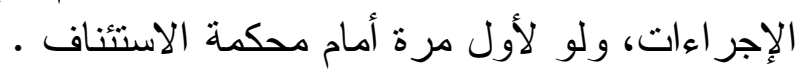

Dans toute procédure le concernant, le mineur capable de ) ' discernement peut, sans préjudice des dispositions prévoyant son intervention ou son consentement, être entendu par le juge ou, lorsque son intérêt le commande, par la personne désignée par le juge à cet effet.Cette audition est de droit lorsque le mineur en fait la demande. Lorsque le mineur refuse d'être entendu, le juge apprécie le bien-fondé de ce refus. Il peut être entendu seul, avec un avocat ou une personne de son choix. Si ce choix n'apparaît pas conforme à l'intérêt du mineur, le juge peut procéder à la désignation d'une autre personne.L'audition du mineur ne lui confère pas la qualité de partie à la procédure.Le juge s'assure que le mineur a été informé de son droit à être entendu et à être assisté

par un avocat. 
من ذلك يتضح أن المشرع الفرنسي قد قرر حق الطفل في أن يقدم

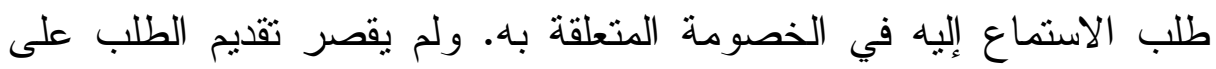

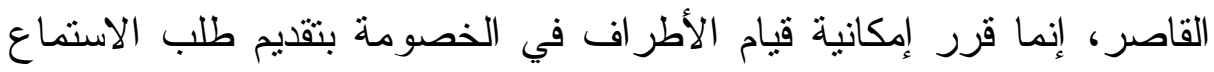

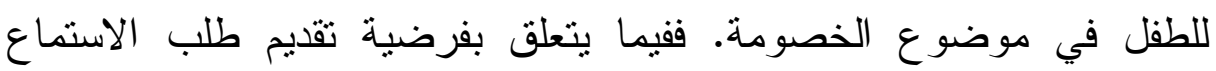

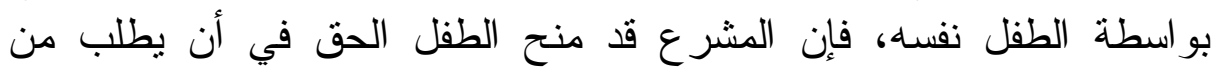

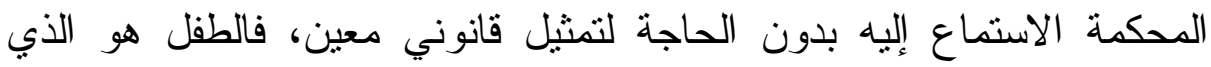

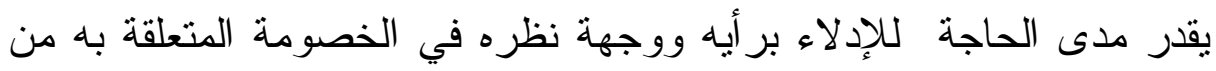

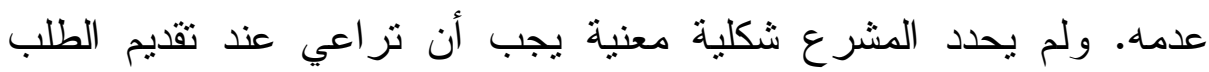

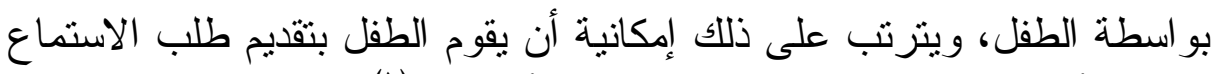
إليه في أية صورة كانت سو اء كانت شفهية أم كتابية(').

وفي هذا الصدد، فقد أثثرت مسألة مدى إمكانية أن يقدم طلب الاستماع

بواسطة شخص من الغير نيابة عن الطفل مثال ذلك الطلبات المقدمة من خلال الته

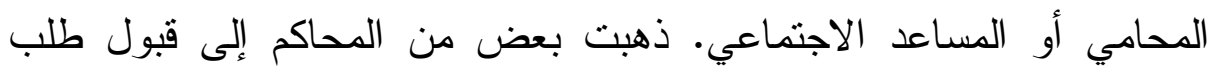

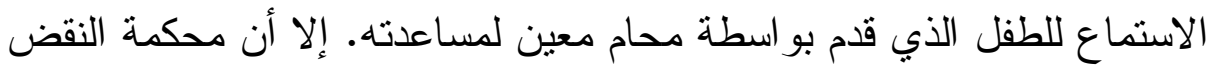

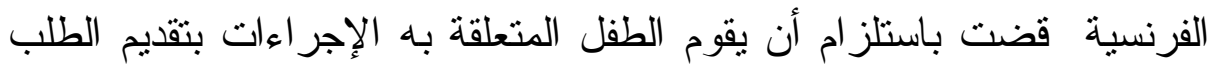

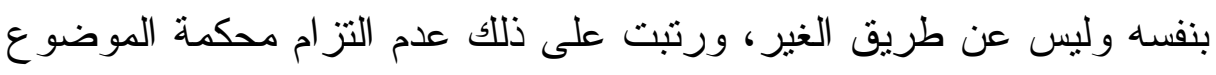

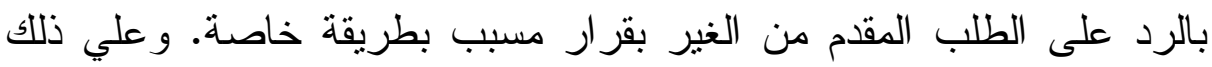

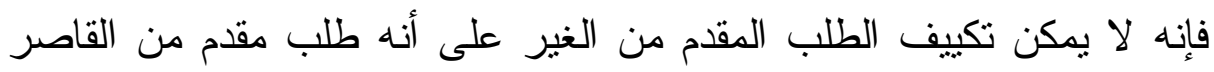
نفسـه

ولقد تعرض هذا القضاء للنقد على أساس من القول أنه إذا كان حقيقي

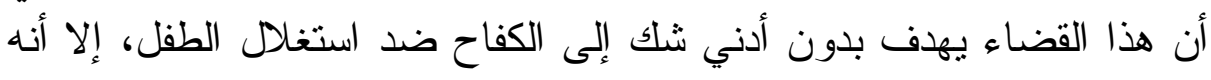

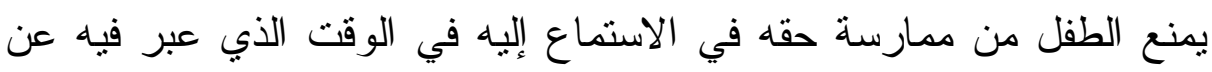

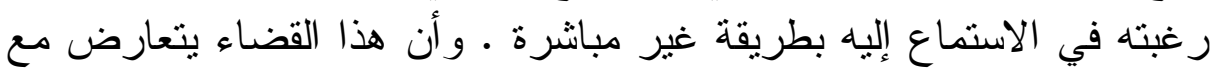

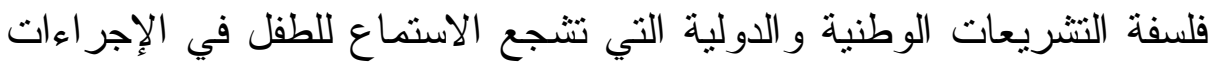
المتعلقة به وتمكينه من التعبير عن وجهة نظره كلما اتيحت الفرصة لذللك.

(1) CA Montpellier, 24 fev.2007, CA Douai, 19 oct.2006, cites par C. Watine - Drouin, Minorité, Audition du mineur en justice Défense de ses intérêts op. cit. n 57.

2 Cass. 1re civ., 19 sept. 2007 : Dr. famille 2007, comm. 192, note P. Murat. 
أما فيما يتعلق بتقديم طلب الاستماع للطفل من خلال أطراف

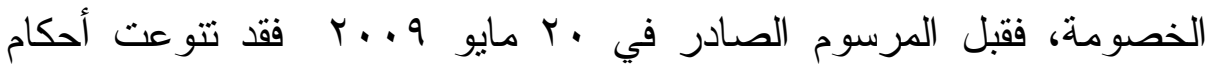

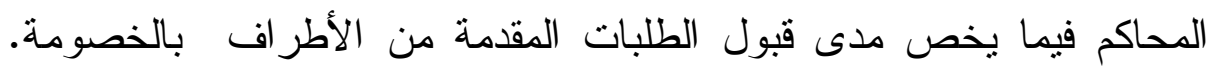

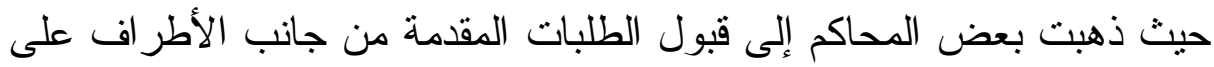

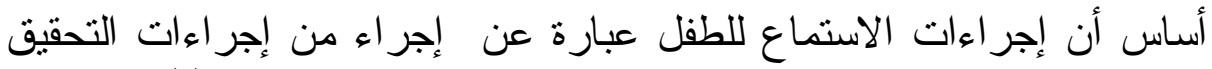

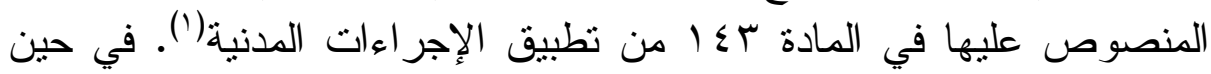

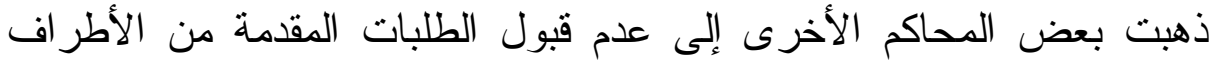

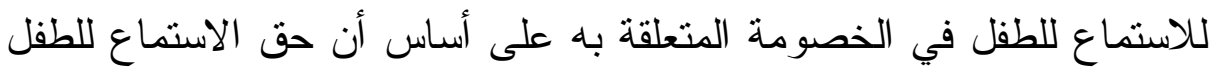

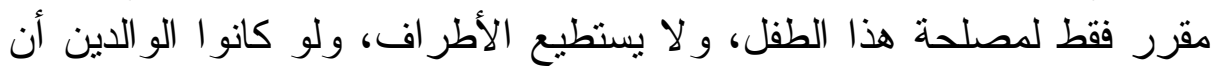

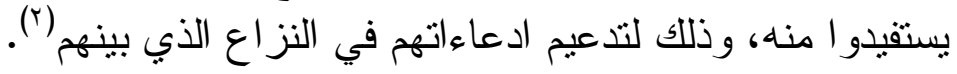

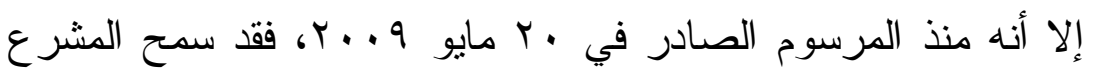

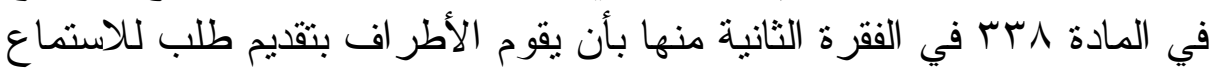

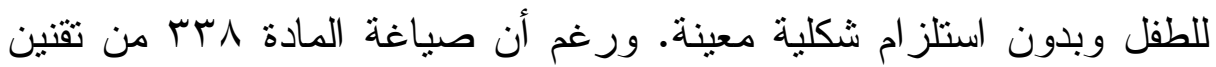

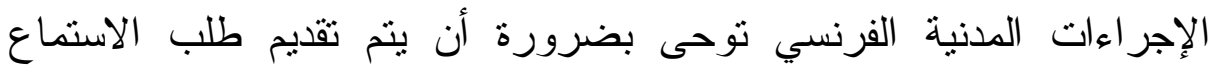

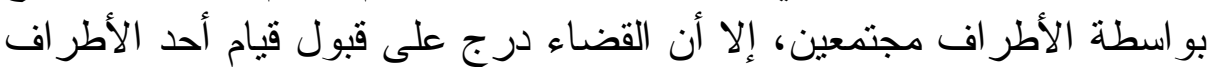

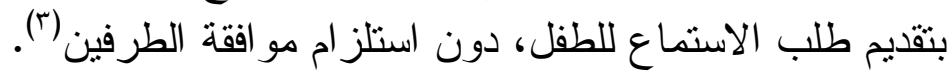

وجدير بالذكر - في هذا المقام - أن نشير إلى أن طلب الاستماع

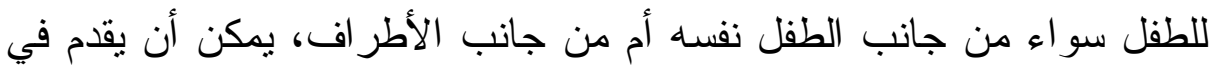

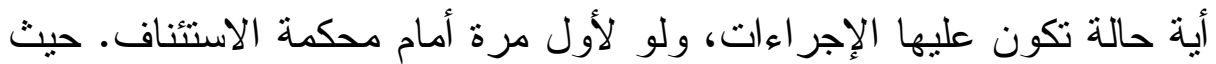

(1) CA Aix - en province, 9 avr . 1997 ; CA Agen2002 cites par. C . watine - Drouin, op.cit.. n 64.

(2) CA Lyon, 25 Janv . 1994 : CA Papeete, 17 nov.2005 cites par. C . watine - Drouin, op.cit.. n 64.

(1) B. Mallevaey, Étendue du contrôle opéré par les juges du fond sur la demande d'audition d'un mineur formée par les parties à la procédure JCP G. $\mathrm{n}^{\circ}$ 12, 21 Mars 2016, p.326, CA Chambéry, 3e ch., 10 juill. 2012, $\mathrm{n}^{\circ}$ 11/02157), CA Pau, 2e ch., 31 mars 2015, $\mathrm{n}^{\circ}$ 14/01329 : JurisData ${ }^{\circ}$ 2015-007290), CA Douai, 7e ch., 19 déc. 2013, $n^{\circ}$ 12/00959 : JurisData ${ }^{\circ}$ 2013-033569), CA Grenoble, ch. aff. fam., 16 juill. 2015, $\mathrm{n}^{\circ} 14 / 02563$ : JurisData $\mathrm{n}^{\circ}$ 2015019901. 


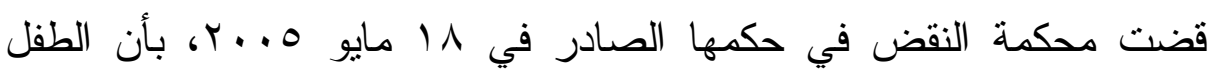

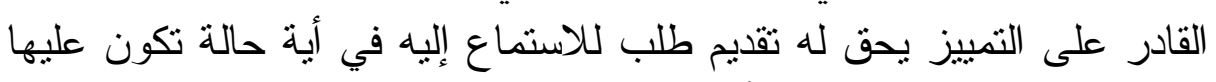

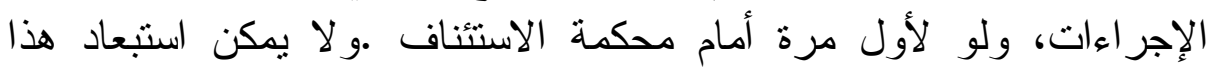

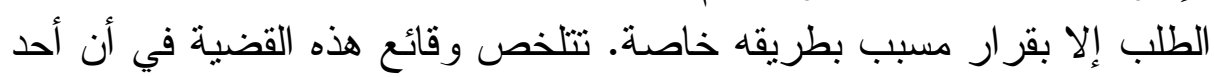

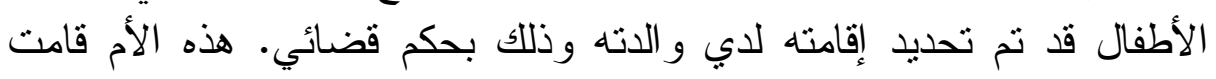
بالزو اج بعد ذللك وهاجرت إلى الولايات المتحدة الأمريكية. فقام و الد الطفلة الألة

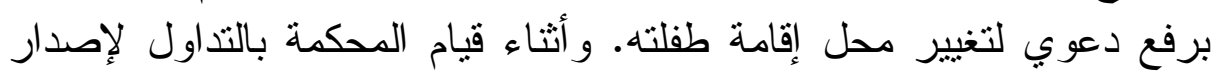

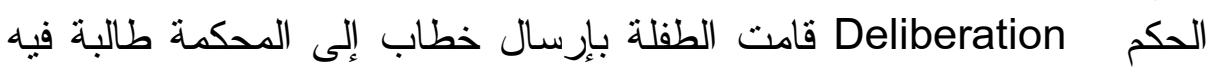

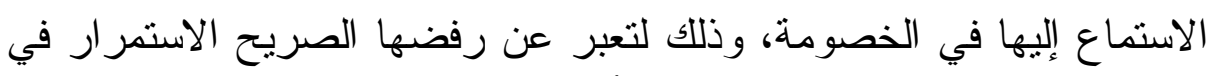
الإقامة مع و الدتها بالو لايات المتحدة الأمريكية.

قامت محكمة الاستئناف بعدم الاعتداد بهذا الطلب وقامت بإصدار حكم

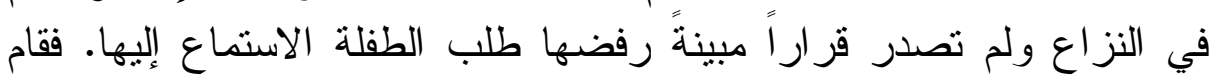
و الد الطفلة بالطعن على الحكم الصادر من محكمة الاستئناف وذللك لعدم قيام

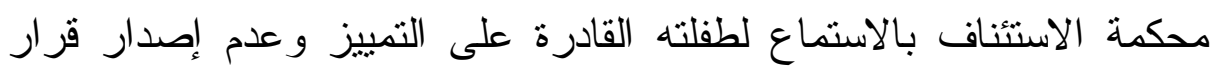

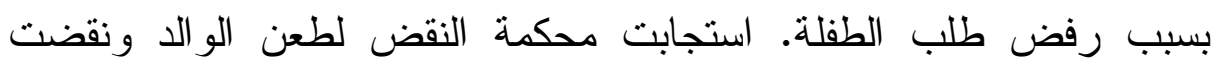

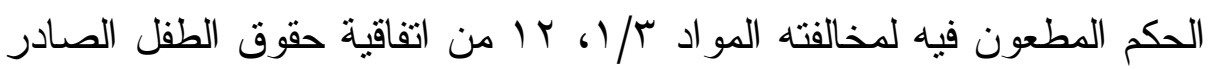

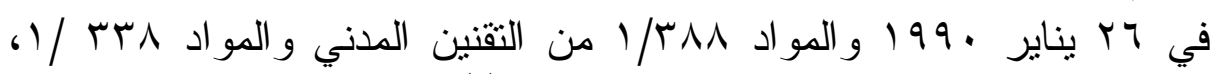

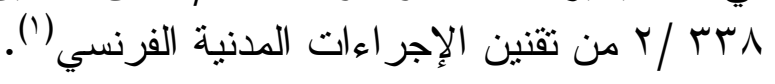

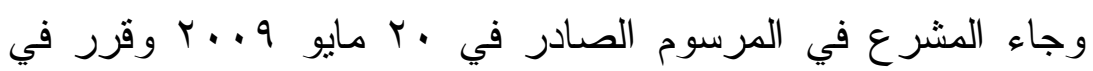

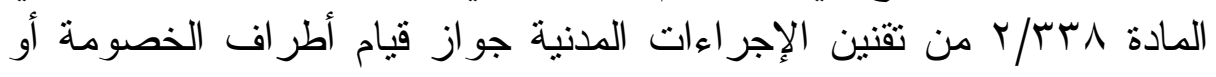

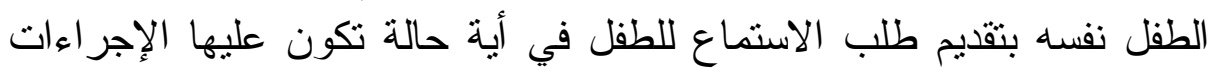

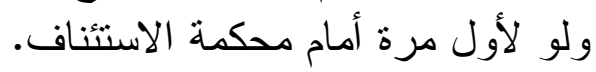

وقد أثثير تساؤل حول مدى إمكانية تكرار طلب الاستماع للطفل في

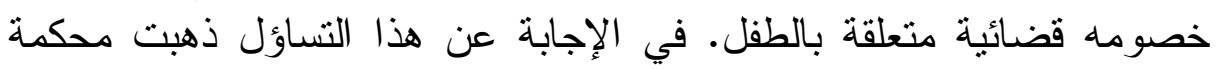

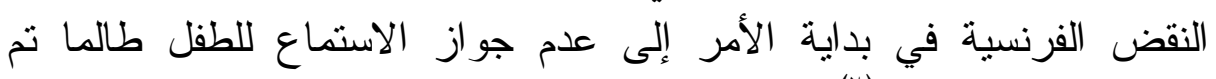
الاستماع إليه قبل ذلك (؟).

(1) Cass civ . 18 mai 2005, Rev. Lamy Droit civ. 2005, p.18 .

(2) Cass Civ. 28 , 15 meus 2001 , RJPF 2001 , p.20, obs . p Guerder . 
إلا أنها غيرت من موقفها السابق في حكمها الصادر في گr أكتوبر

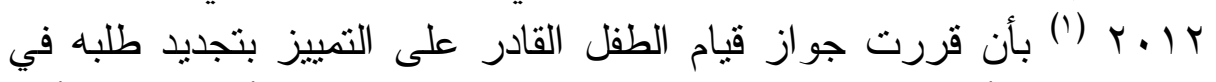

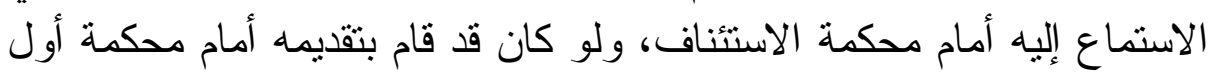

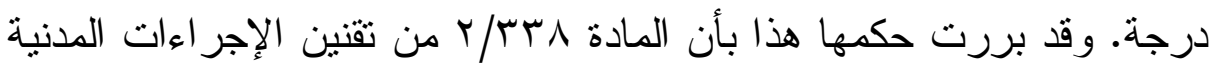

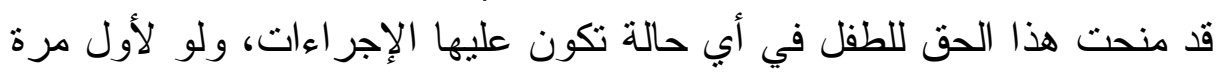

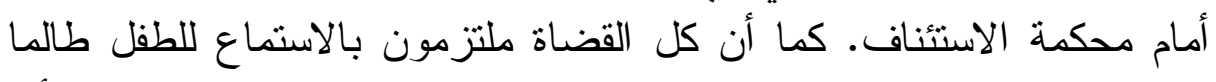

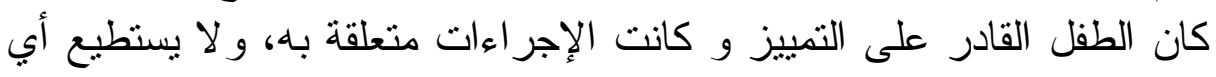

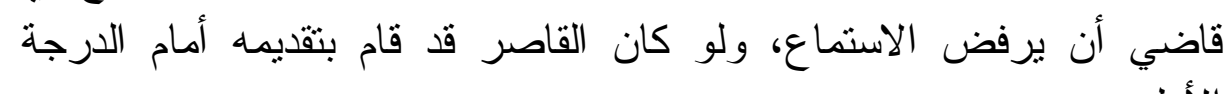

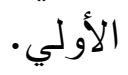

ولقد قام المشرع الفرنسي بتنظيم سلطة المحكمة في قبول طلب

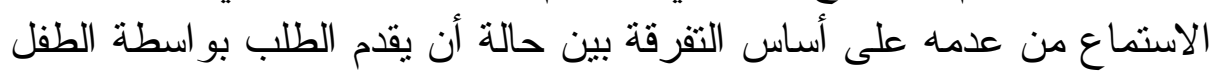

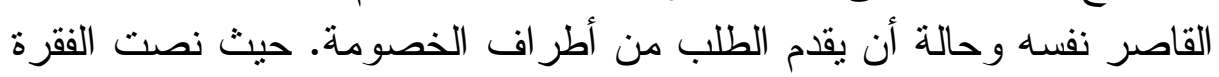

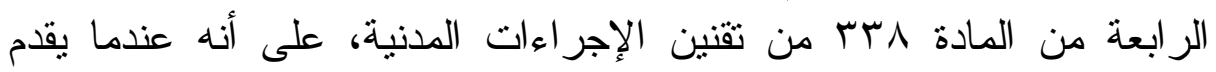

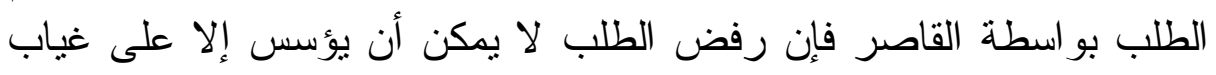

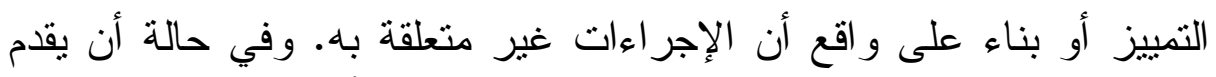

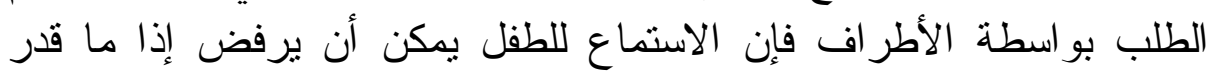

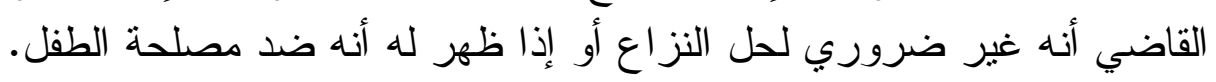

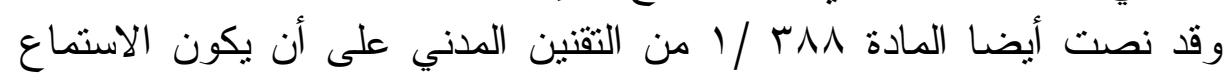
للطفل بقوة القانون إذا طلب هو ذلك.

وبذلك فإنه في حالة أن يقدم الطلب بواسطة الطفل، فإن هذا الطفل

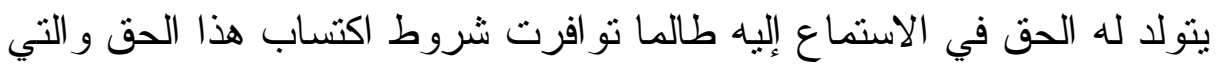

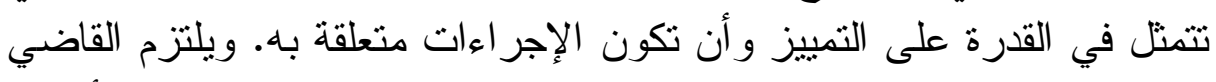

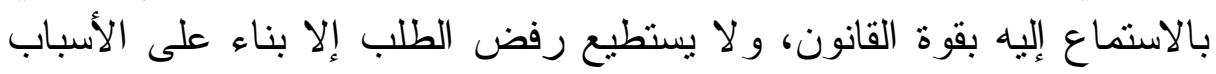

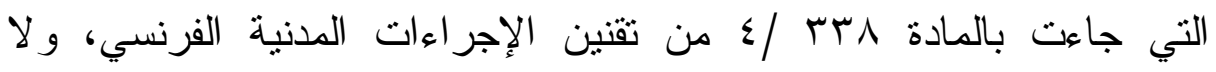

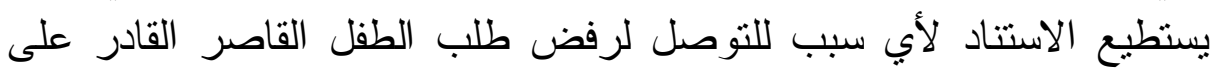

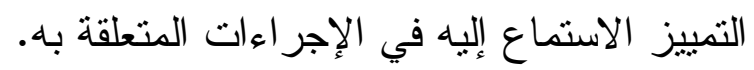

(1) Cass Civ ire, 24 oct .2012, RJPF ,2012, P22 . 


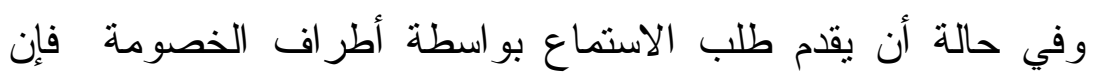
القاضي يستطيع أن يرفض الاستماع للطفل - بالإضافة إلى الأسباب المتعلقة

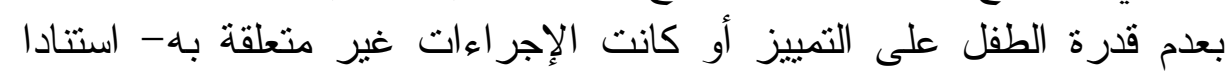

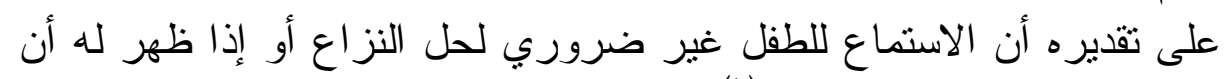

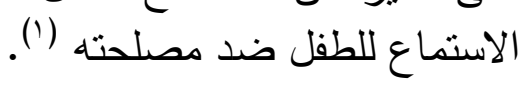

وقد قضت محكمة النقض الفرنسية في حكم حديث لها صدر في 17

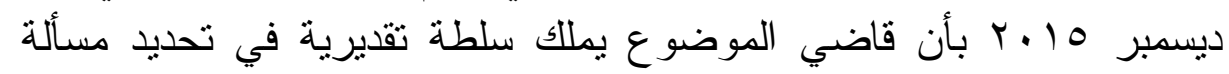

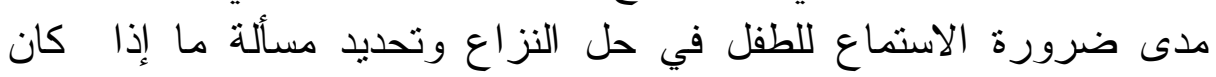

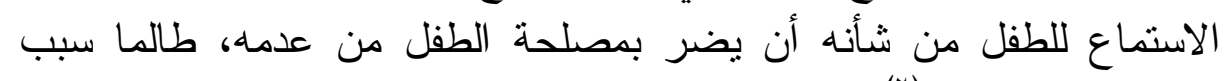

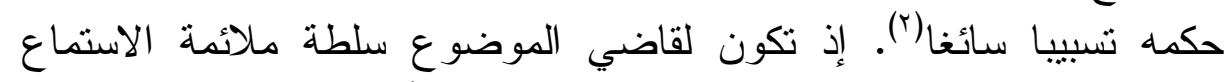

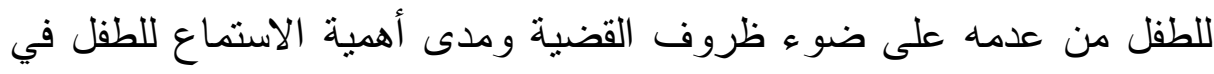

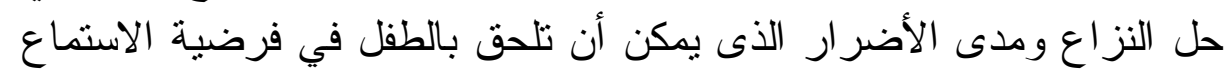
إليه.

ويقوم القاضي بإعلام القاصر والأطر اف بقرار الرفض في حالة ما فالإلها

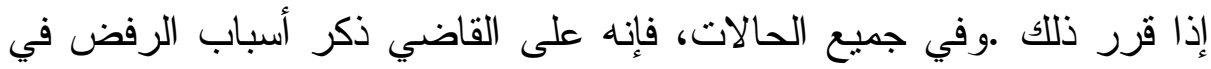

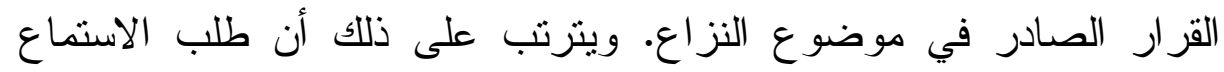

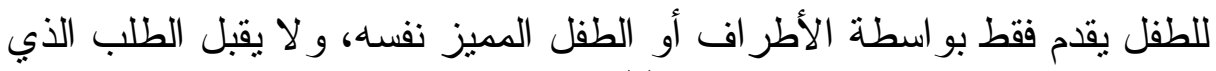
يقدم بو اسطة شخص من غير هؤلاء (r).

(1) B. Mallevaey, Étendue du contrôle opéré par les juges du fond sur la demande d'audition d'un mineur formée par les parties à la procédure JCP G. n 12, 21 Mars 2016, p.328.

(2) Cass. 1re civ., 16 déc. 2015, $\mathrm{n}^{\circ}$ 15-10.442,: JurisData $\mathrm{n}^{\circ}$ 2015027902 cite par B. Mallevaey, Étendue du contrôle opéré par les juges du fond sur la demande d'audition d'un mineur formée par les parties à la procédure JCP G. n 12, 21 Mars 2016, p.328.

$\left({ }^{3}\right)$ A. Zelcevic-Duhamel, L'absence d'audition de l'enfant n'est pas nécessairement contraire à ses intérêts, JCP G, $n^{\circ} 6,6$ Février 2008, II p.10026. 
و تتص الفقرة الخامسة من المادة مسب من تقنين الإجر اءات المدنية

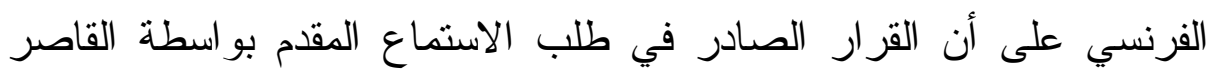

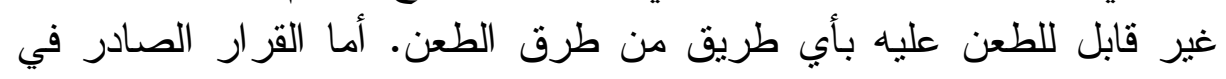

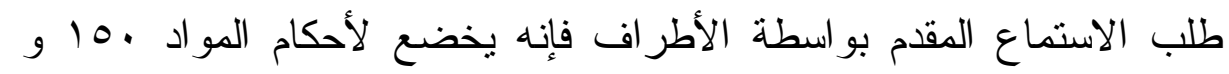

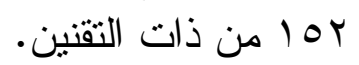

وبذلك فإن المشرع قد حظر الطعن على القرار الصادر في طلب

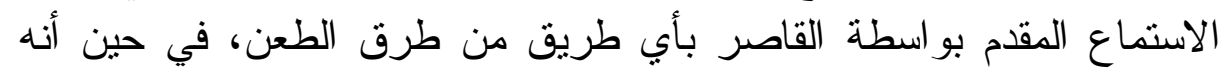

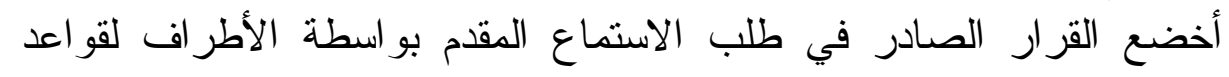

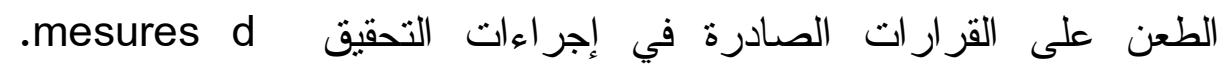
instruction

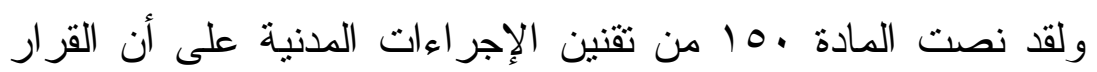

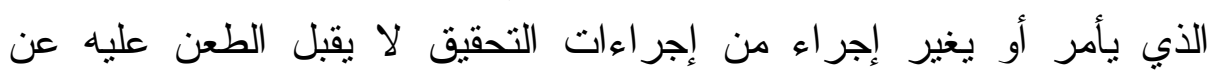

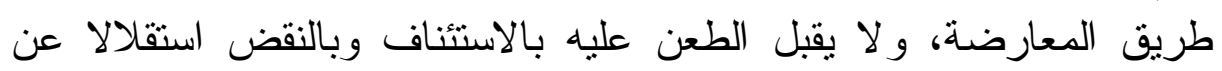

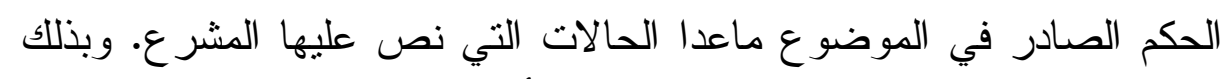

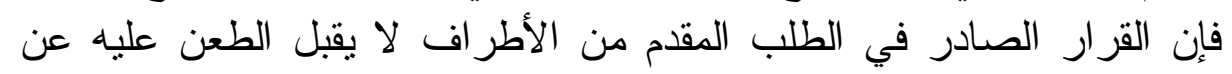

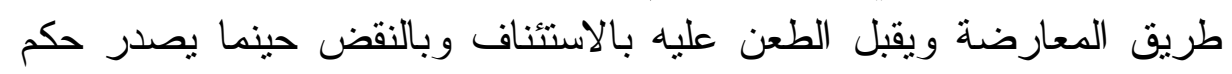

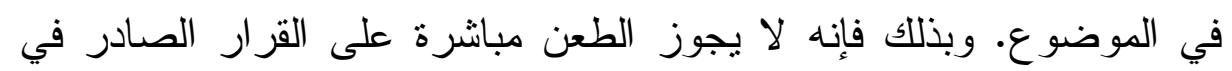

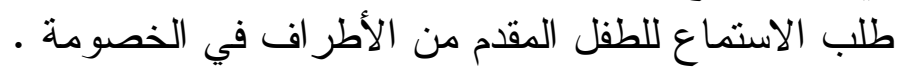

ومن الجدير بالذكر -فى هذا السياق - أنه رغم عدم نص المشرع

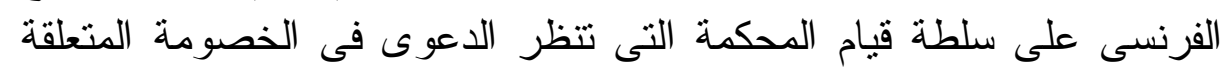

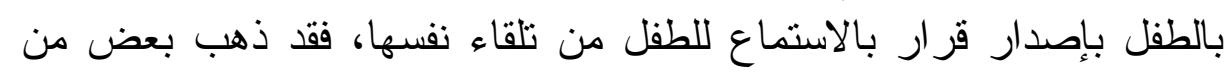

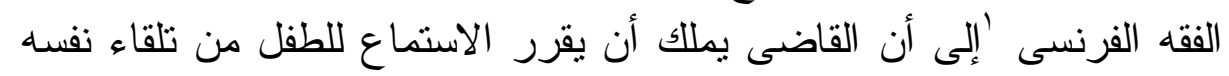

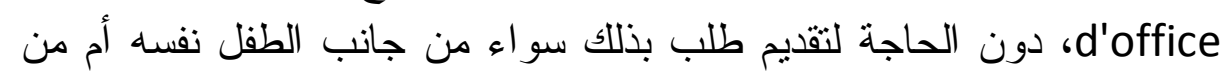
جانب أحد أطر اف الخصومة.

إذ أنٍ السماح للقاضى باستدعاء الطفل من أجل الاسنماع إليه يعد

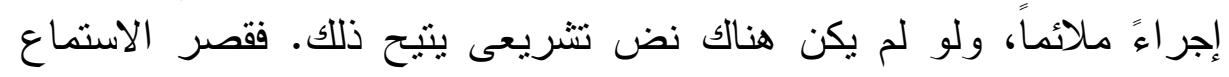

1 J. Carbonnier, Droit civil, t. II, La famille, l'enfant, le couple, 21e éd., 2002,p. 153 


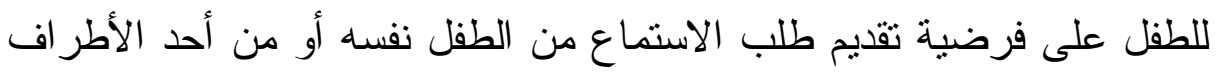
يمكن أن يؤدى إلى تحجيم الاستفادة من إجر اء الاستماع للطفل، كذلك من شأنه الأنه

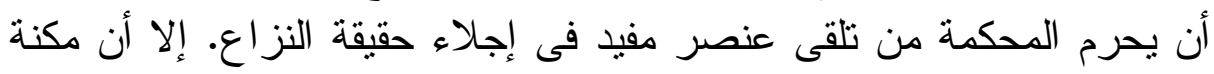

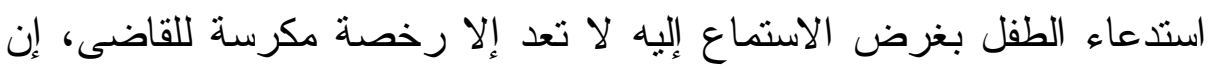
شاء لجأ إليها، و إن قدر عدم وجود فائدة منها، فحينئذ فلا تسريب عليه.

ومن المقرر فى الفقه الفرنسى' أنه إذا قرر القاضى الاستماع للطفل

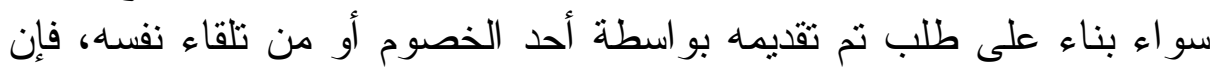

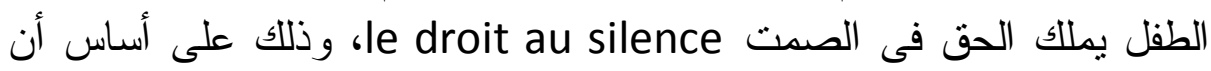
هذا الحق نتيجة طبيعة للاعتر اف للطفل المميز بالحق فى الاستماع إليه، فله

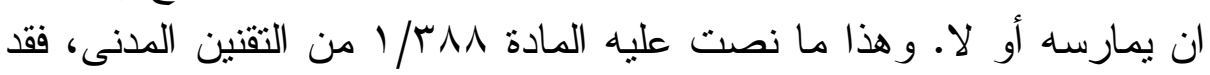
تضمنت هذه المادة فقرة تذل على حق القاصر فيل في على عدم الاستماع إليه.

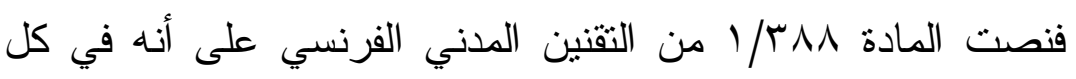

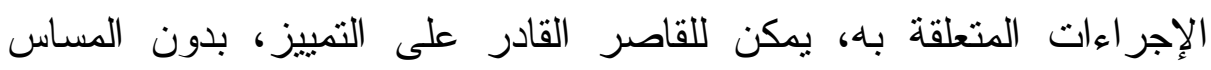

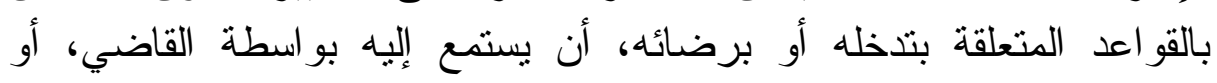

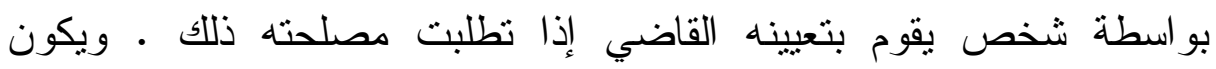

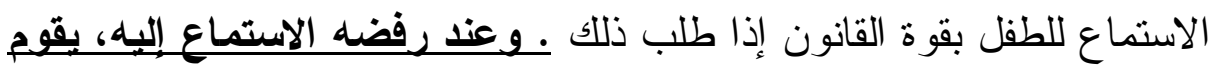

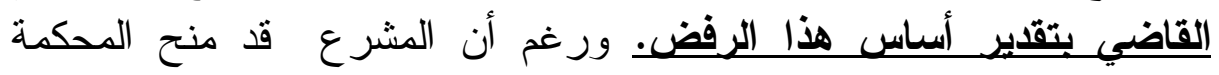

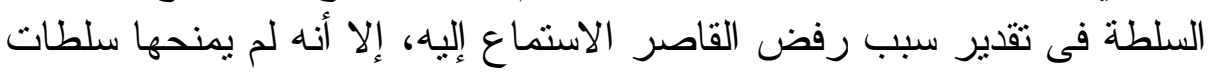

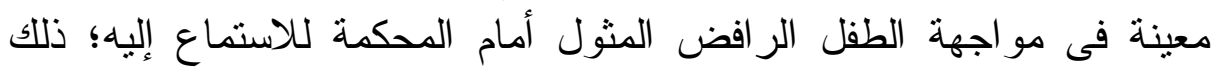

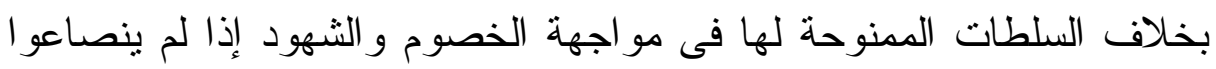
لقرار المحكمة. ولها أن تقدر سبب الرفض وتأخذه فى الاعتبار عند إصدار حكمها.

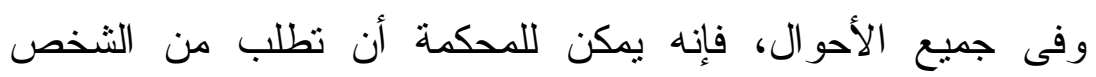

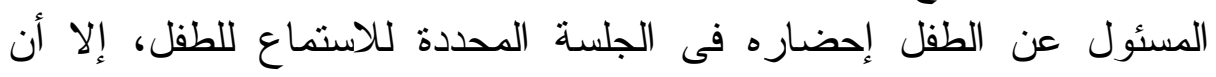
المحكمة لا تستطيع أن تجبره على الكلام أو تضغط عليه بأية وسيلة كانت.

1 C.Watine - Drouin, Minorité, audition du mineur en justice, Défense de ses interest, Fasc.unique, prest, no 62,p.36. 
العدد الأول - الجزء الأول - السنة الثامنة الخمسون- يناير 19.r

\section{المطلب الثاني}

\section{أليات الاستماع للطقل في الخصومة المدنية}

عندما يصدر قرار من المحكمة بالاستماع للطفل، يظهر على بساط

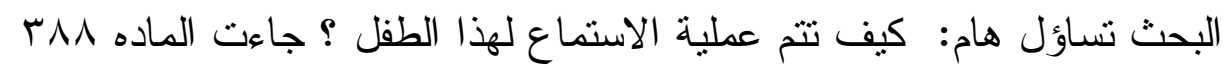

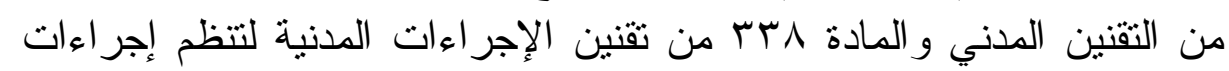
الاستماع للطفل، وتجيب عن هذا التساؤل.

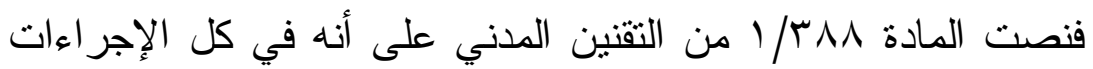

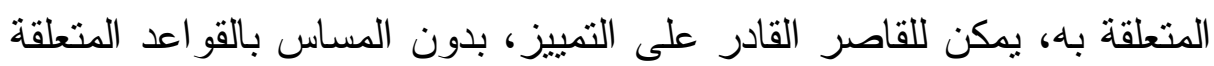

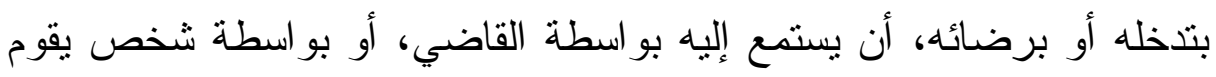

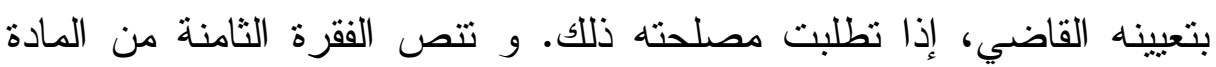

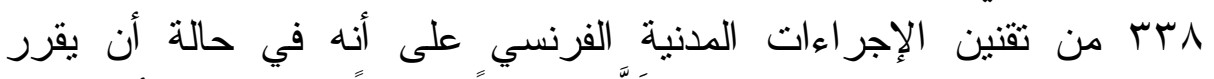

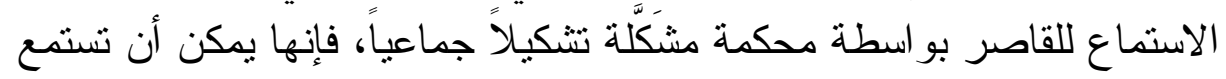

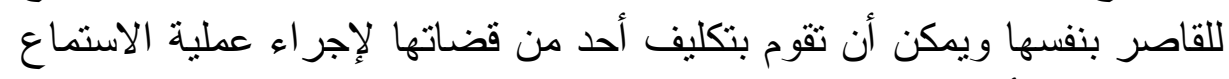
للقاصر على أن يحرر محضر بذلك.

وتتص الفقرة التاسعة على أنه في حالة أن يقدر القاضي أن مصلحة الطفل تتطلب ذللك، فإنه يقوم بتعيين شخص ليقوم بالاستماع للطفل، ويشترط

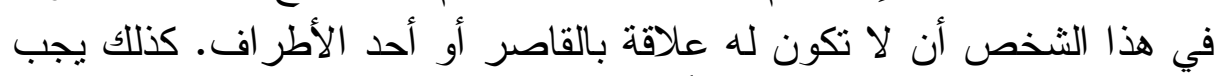

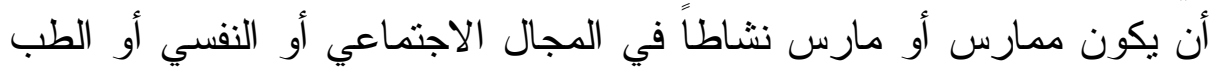

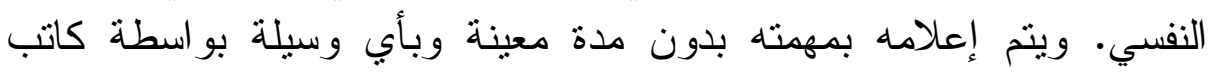

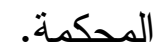

من خلال هذه النصوص يتضح أن المشرع الفرنسي قد حدد أليتين يتم

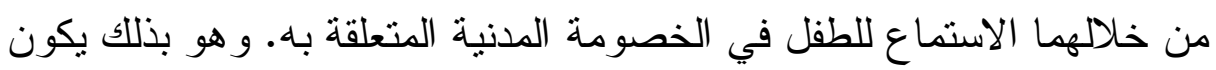

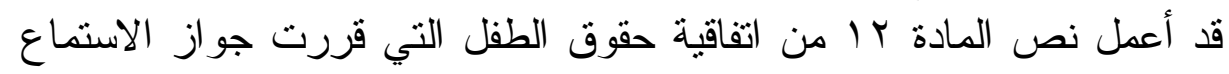

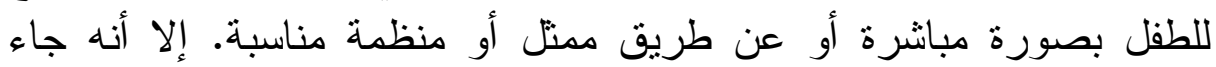

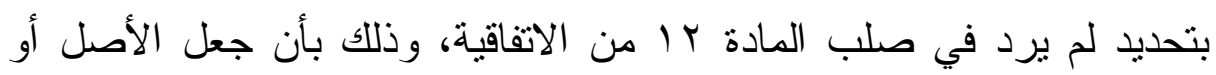
المبدأ في الاستماع للطفل أن يكون عن طريق المحكمة أو أحد قضاتها، وليس

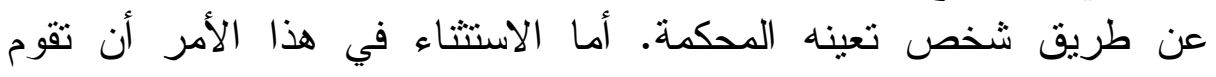


المحكمة باختيار شخص للقيام بهذه المهمة، وذلك في حالة أن تتطلب مصلحة الطفل ذللك.

وإذا قررت المحكمة أن تستمع بنفسها للطفل في الخصومة التي تتعلق به، فإنها يمكن أن تقوم بذلك بكامل هيئتها، أو تكلف أحداً من قضاتها فئها

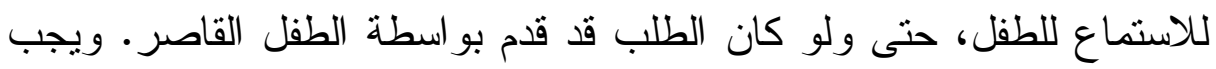
على القاضي الذي يستمع للطفل أن يحرر محضر الذئكر فيه مضمون المقان المقابلة التي تمت مع الطفل.

أما إذا قررت المحكمة أن مصلحة الطفل تتطلب تعيين شخص ليقوم

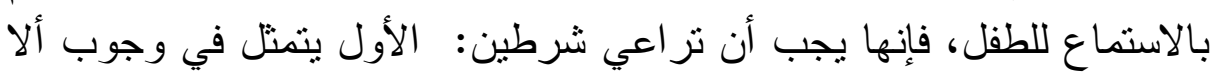

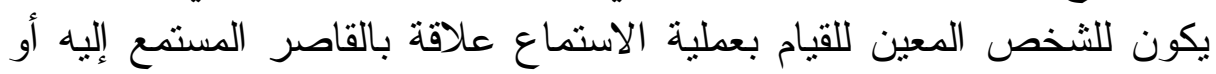

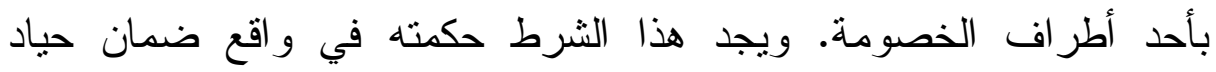

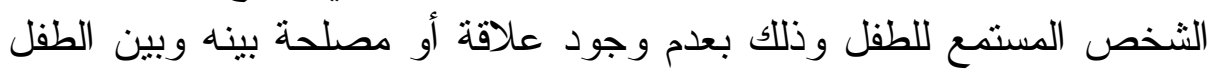

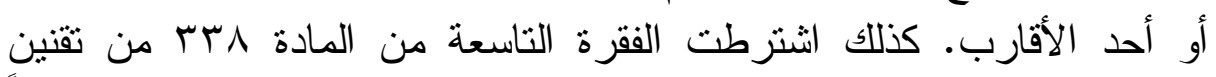
الإجراءات المدنية الفرنسي أن يكون هذا الثخص ممارس أو مارس نشاطاً في المجال الاجتماعي أو النفسي أو الطب النب النفي. حيث إن إن عملية الاستماع

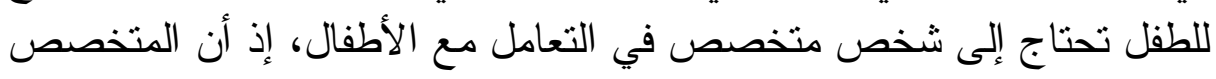

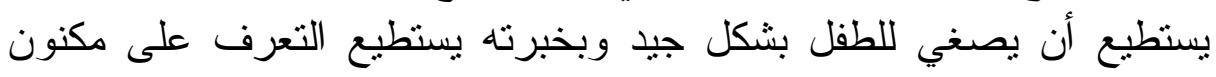

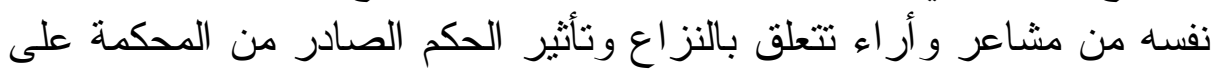

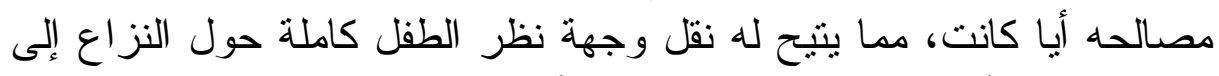

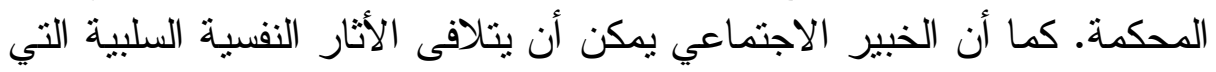

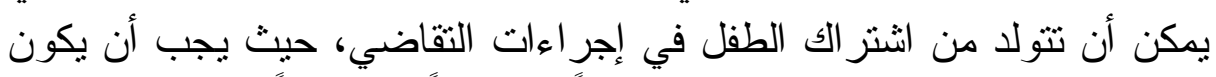

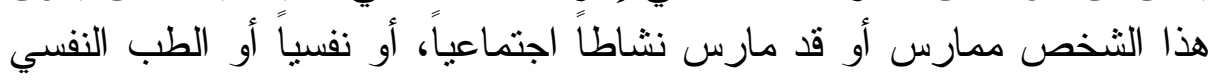

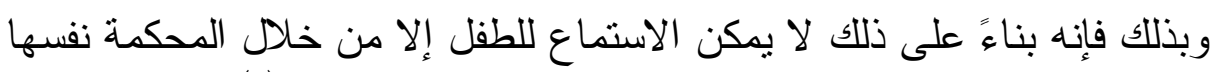

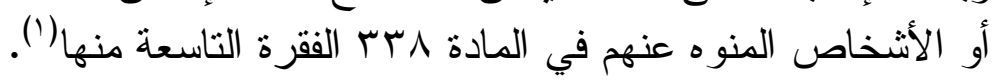

و تتص الفقرة السادسة من المادة مبس من تقنين الإجر اءات المدنية

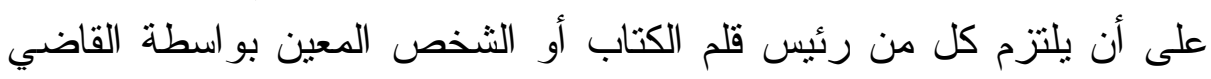

(1) J .Raphael .Demarch, Une Justice familile en mutation, Bilan de l'évolution législative relative à l'audition de l'enfant, LPA, 17 mas 2010, n 54, p.25. 
للاستماع للطفل بإرسال خطاب بسيط إلى الطفل وذلك لاستدعائه بهدف

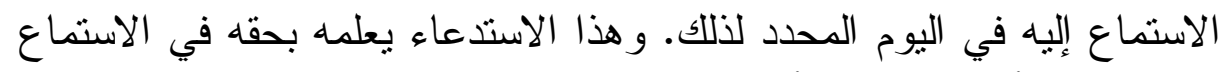

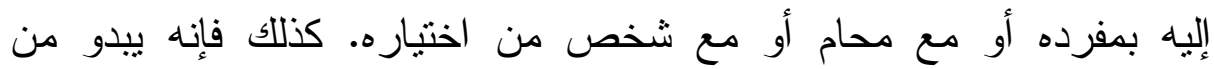
الضروري أن يتم إعلام المدافعين عن الأطر اف أو الو الأطر اف أفئ أنفسهم باليوم

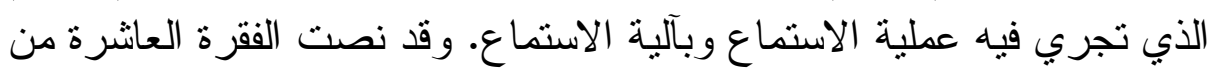

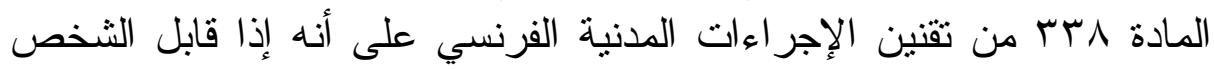

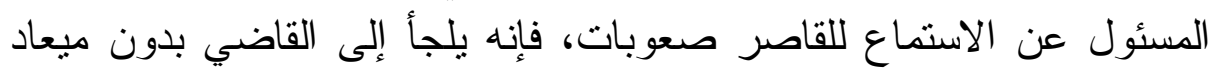

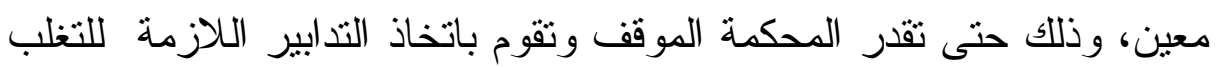

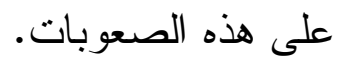

كذلك تتص الفقرة الحادية عشر على أن أليات الاستماع للطفل يمكن

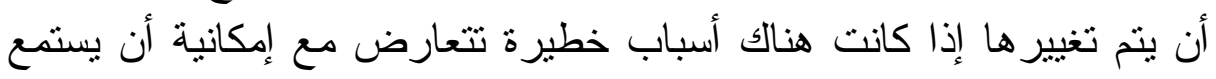

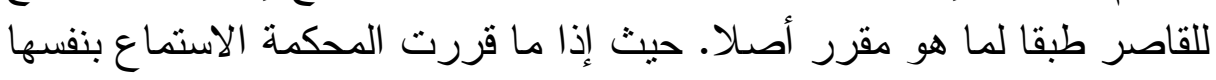
للطفل القاصر ، وظهرت أسباب خطيرة تتعارض مع فئرة فيام المحكمة بعملية

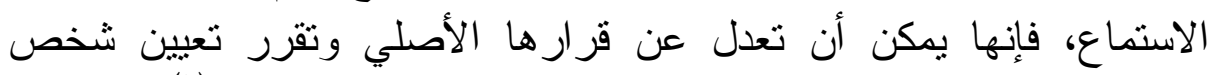

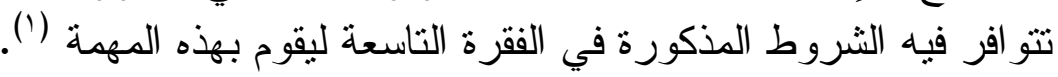
ولقد أثنير تساؤل حول مدى قانونية حضور والدي الطفل جلسة

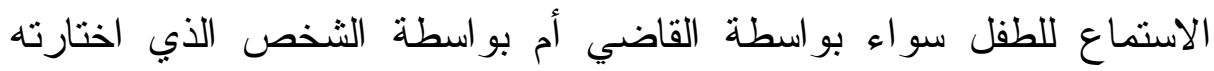

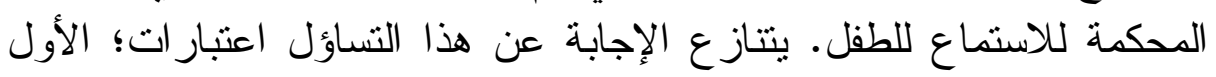

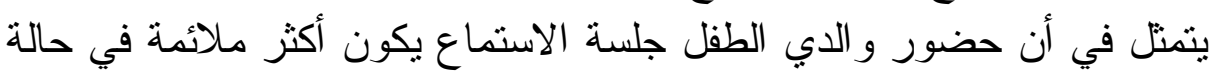

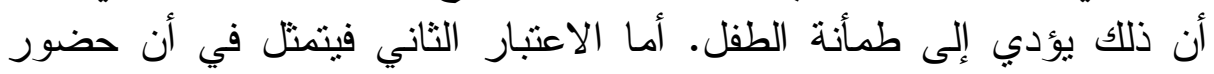
الوالدين قد يؤدي إلى التأثير على حرية الطفل القاصر في الإدلاء برأيه

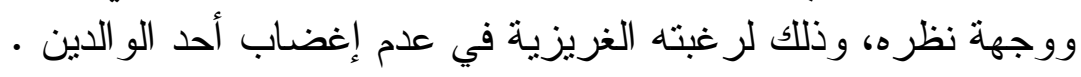

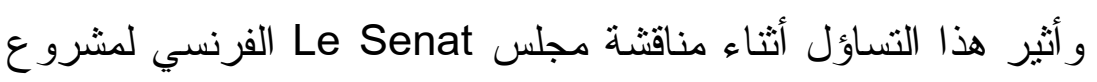

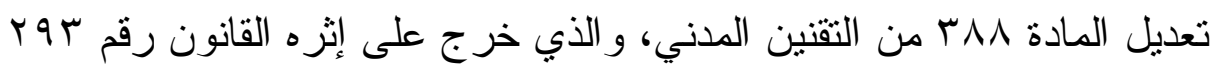

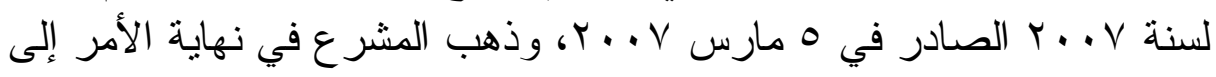

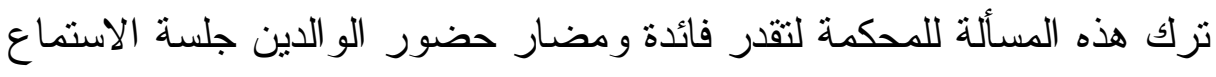

(1) L. François - Terminal, Le nouveau régime de l'audition en justice De l'enfant concerne par une procédure judicaire, Rev. Dr. De la famille, n 9, sep -2009. Etude 30, n 33 .p.15. 


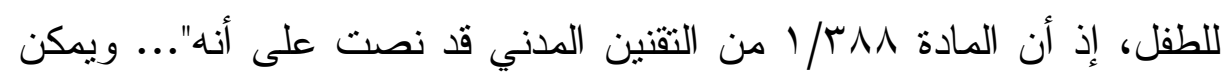

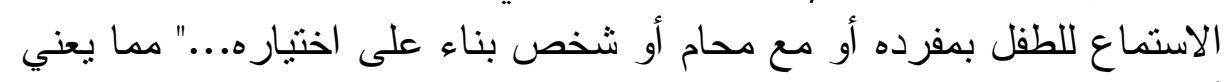

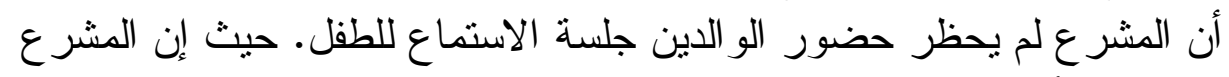

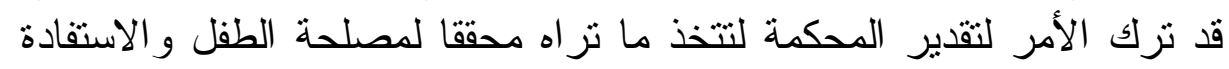
الكاملة من الاستماع للطفل (').

\section{المطلب الثالث}

\section{أهم ضمانات الاستماع للطقل في الخصومة المدنية}

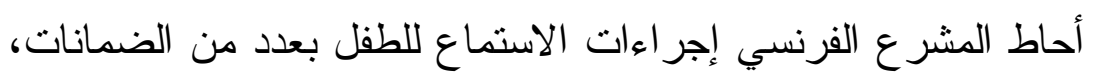

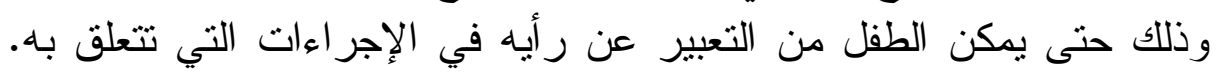
ومن أهم هذه الضمانات تكريس حق الطفل في اصطحاب أحد الأثخاص أثناء

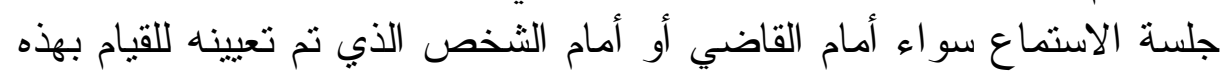

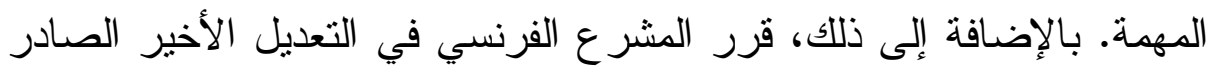

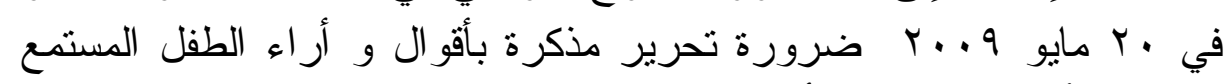

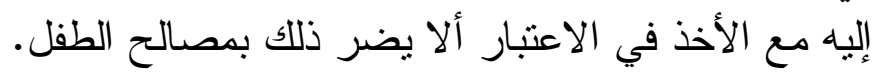

\section{الفرع الأول}

حق الطقل في اصطحاب أحد الاثخاص أثناء جلسة الاستماع

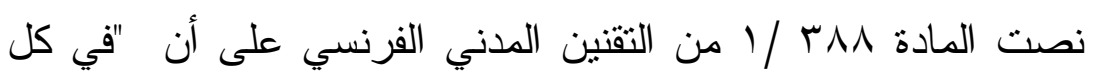

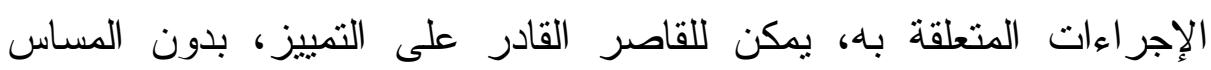

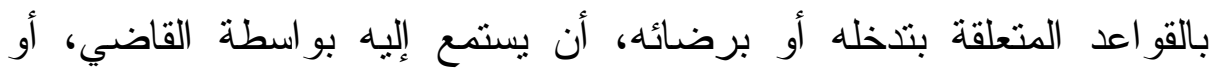

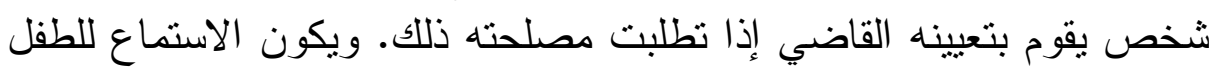
بقوة القانون إذا طلب ذللك. وعند رفض الاستهاع إليه، يقوم القاضي بتقدير

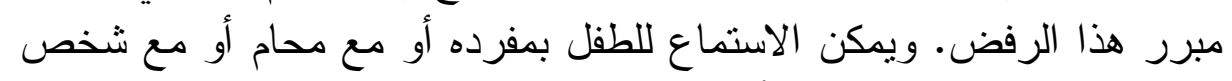

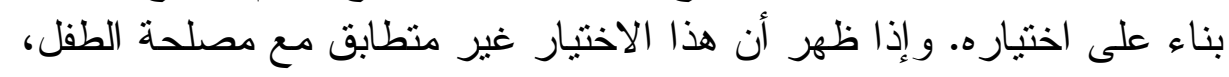
يمكن حينئذ للقاضي أن يقوم بتعيين غيره .

وتتص الفقرة السادسة من المادة مبr من تقنين الإجراءات المدنية

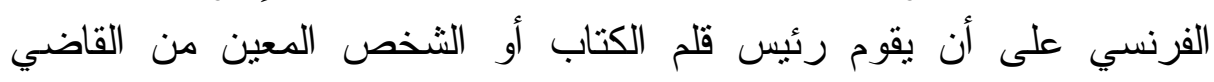

(1) C. Watine - Drouin , Minorité, Audition du mineur en justice Défense de ses intérêts, op.cit. n 75. 
للاستماع للطفل بإرسال خطاب عادي للطفل للاستماع إليه. هذا الاستدعاء

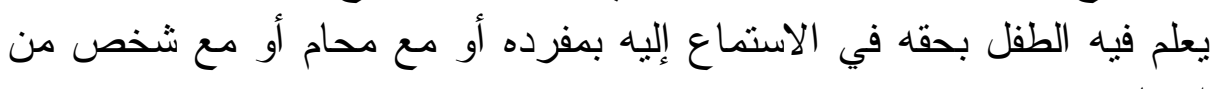

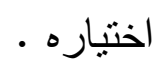

من مجمل هذه النصوص يتضح أن الطفل له حرية أن يقوم بالإدلاء

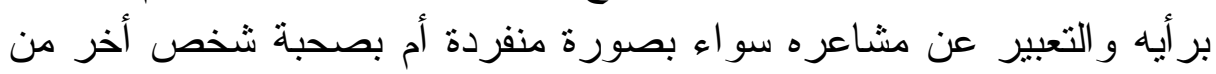

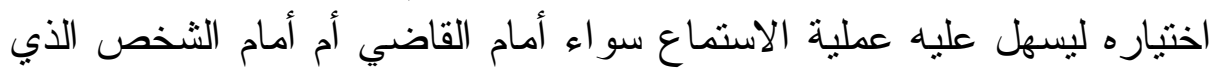

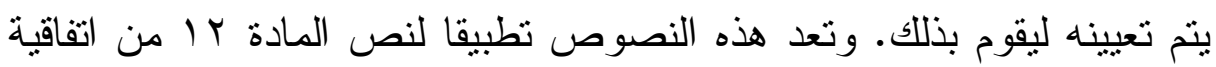

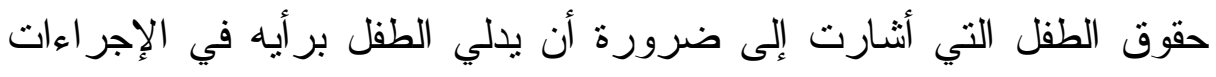

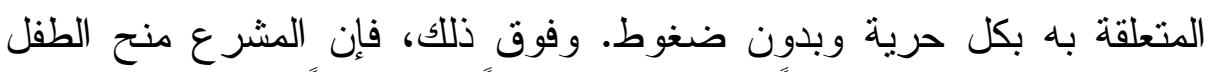

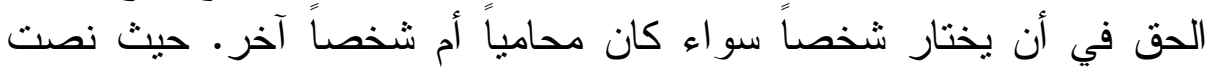

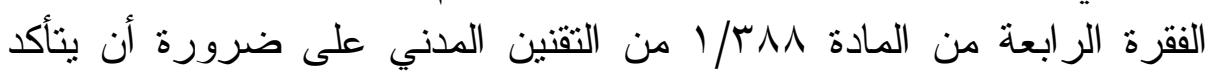

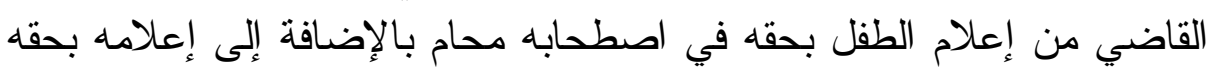
في الاستماع إليه في الإجر اءات المتعلقة به.

وطبقا للفقرة السابعة من المادة مبك من تقنتين الإجراءات المدنية

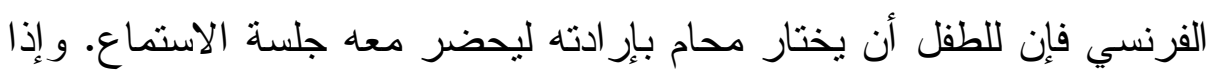

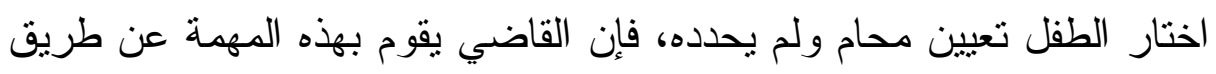

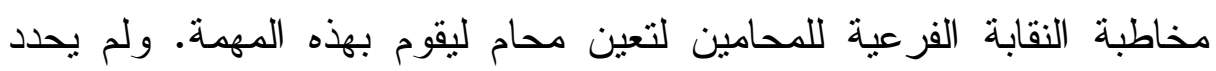

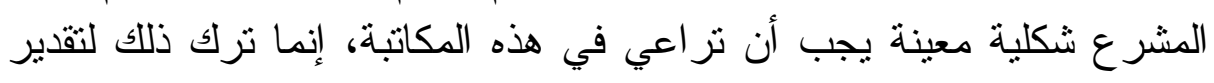

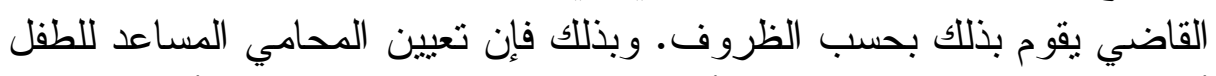

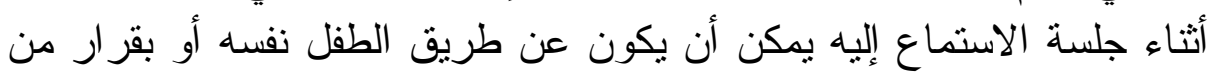
المحكمة التي تنظر الخصومة.

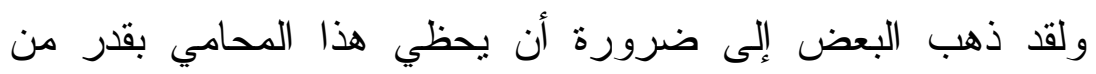

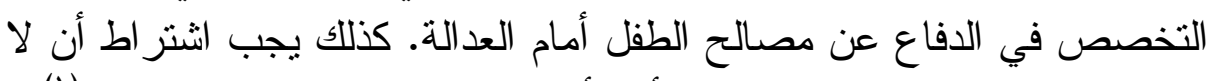

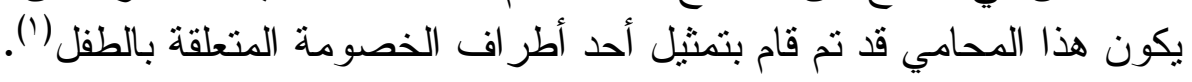

(1) Y .Benhamou, Réflexion en vue d'une meilleure défense en justice de l'enfant, D1993,Chron p.104 ets, ; M .Picot, L'avocat de l'enfant .Rev.Dr famille, 2006 , p. 37. 
ويلاحظ هنا أن مهمة المحامي الذي يحضر مع الطفل المستمع إليه تعد مهمة ذات طبيعة خاصة، فلا يقصد بها أن بقوم المحامي بتمنيل الطفل كوكيل عنه في الخصومة، أو أنه مساعد قانوني بالمفهوم الإجرائي الدقيق.

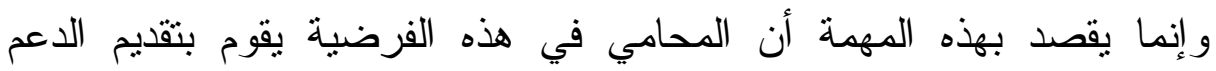

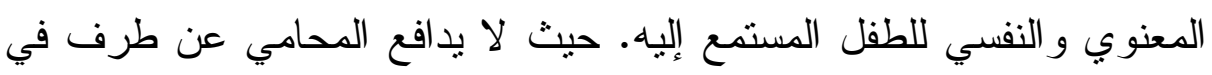

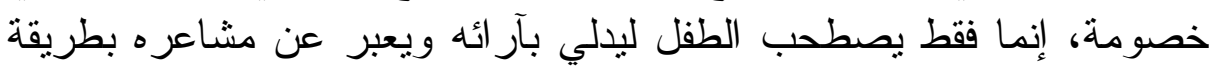
سليمة (') (2)

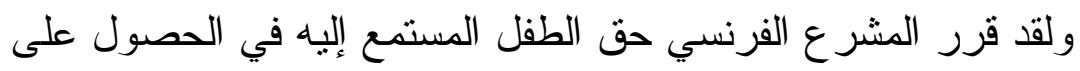

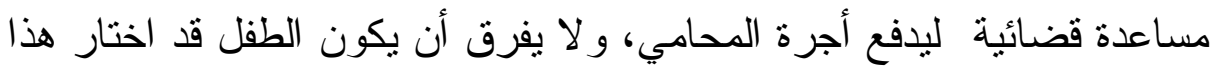

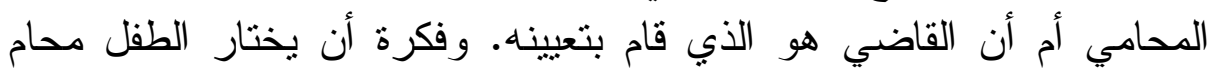

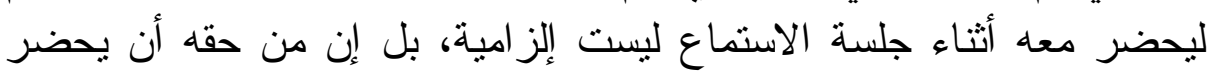
بمفرده أو بصحبة شخص أخر ليس محامٍ.

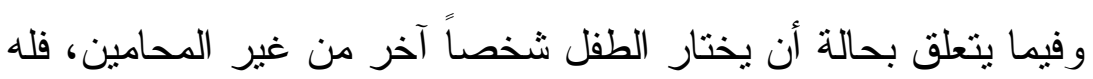

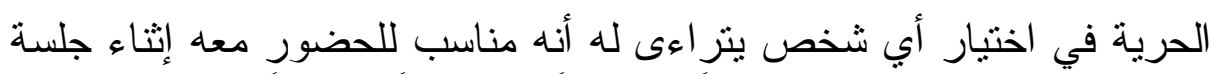

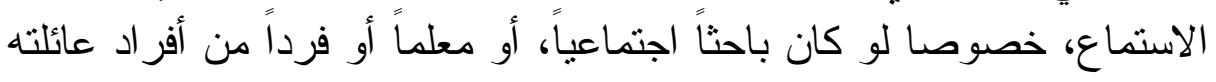

إلا إن هذه الحرية ليست مطلقة، حيث إن من حق القاضي أن ير اقب

مدي كون حضور الثخص المختار بو اسطة القاصر في مصلحته من عدمه.

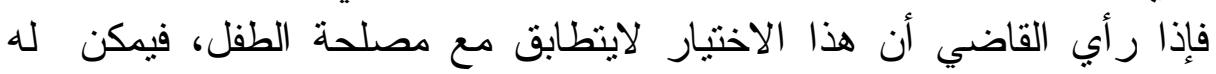

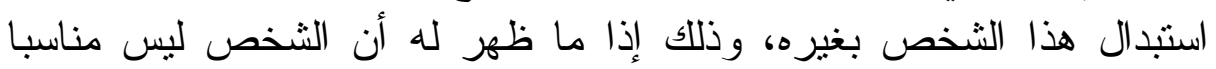

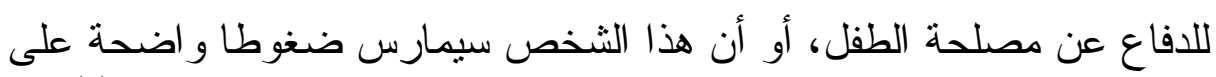

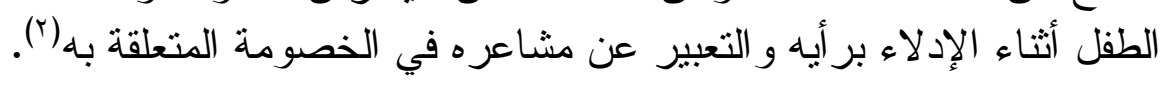

(1) C. Watine - Drouin, Audition du mineur en justice, op.cit. n 80.

( ${ }^{2}$ J .Massip, Les modifications apportées au droit de la famille pas la lai du 28 Javier1993: Defrenois, 193, art .35569, p.673. 
العدد الأول - الجزء الأول - السنة الثامنة والخمسون-يناير 14.r

\section{الفرع الثاني}

مراعاة مصلحة الطقل عند تحرير مذكرة بأقو ال الطقل المستمع إليه

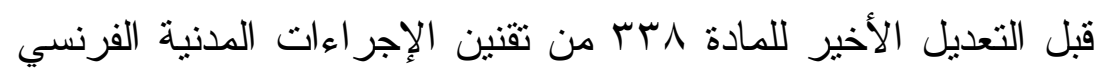

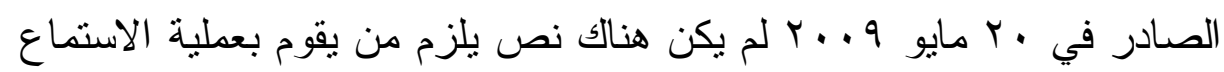

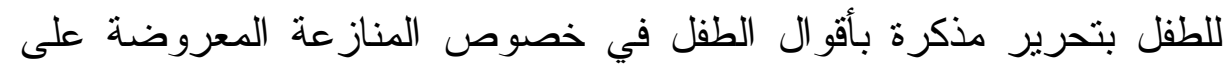

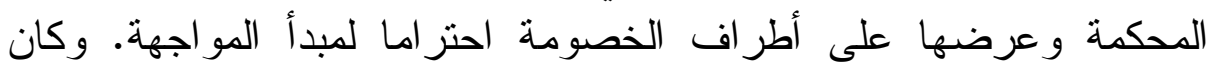

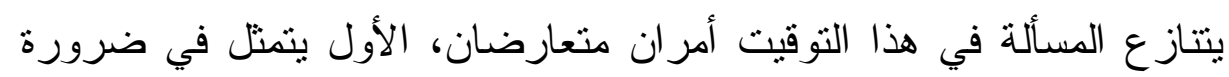

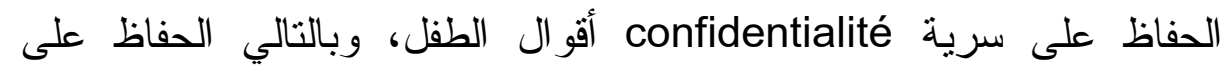
مصالح الطفل أما الثاني فيتمثل في ضرورة احترام مبدأ المواجهة في

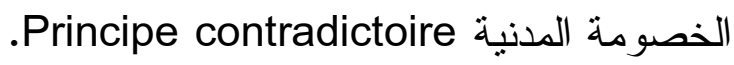

وفي ظل غياب نص تشريعي ينظم المسألة، اقترح جانب من الفقه

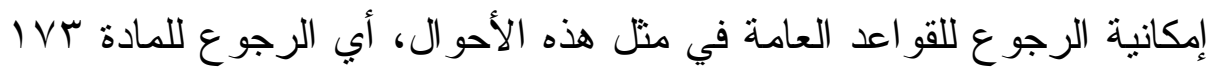

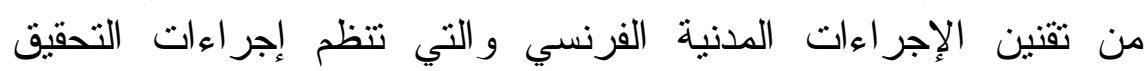
mesures d instruction "

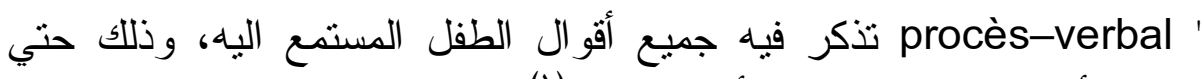
يمكن للأطر اف الإطلاع على أقو ال الطفل (').

وكان يلاحظ قبل التعديل الأخير للمادة مبآ من تقنين الإجراءات

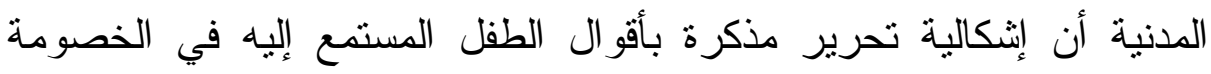

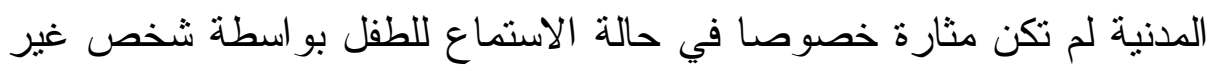

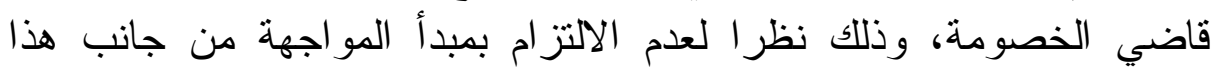
الشخص.

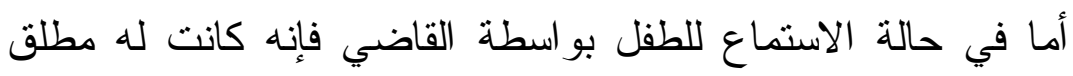

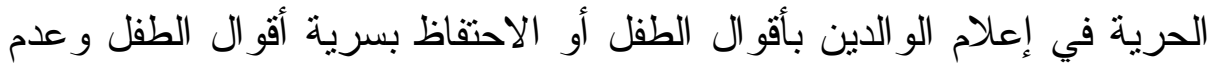

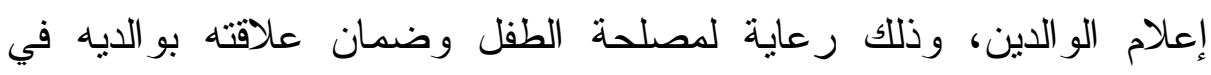

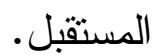

(1) C. Watine - Drouin, Audition du mineur en justice, op.cit. n 77. 
وحسما لهذا الأمر جاءت الفقرة الثانية عشر من المادة مبس من تقنين الإجر اءات المدنية الفرنسي لتقرر إلزام القاضي تحرير مذكرة بأقو ال الطفل

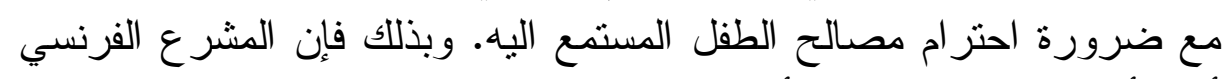

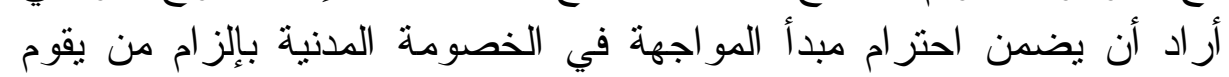

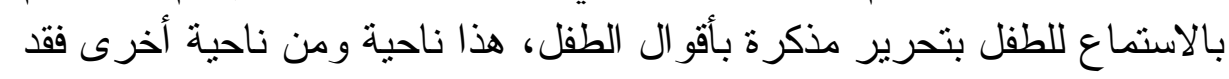

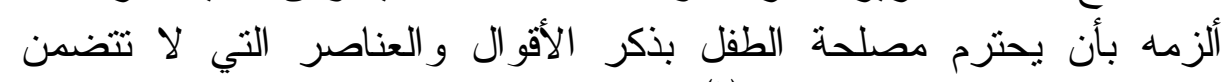
المساس بمصالح الطفل المحمية (').

ويذهب جانب من الفقه إلى ضرورة اثنتر الك الطفل في اختيار العناصر التي يجب ذكرها في مذكرة الاستماع اليه و التي تضمن التعبير

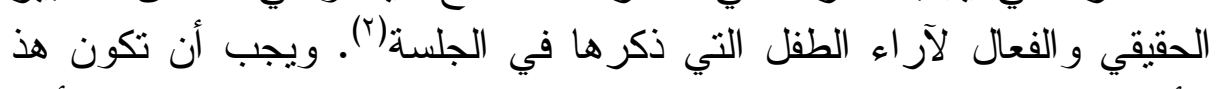

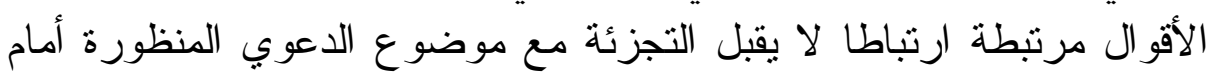

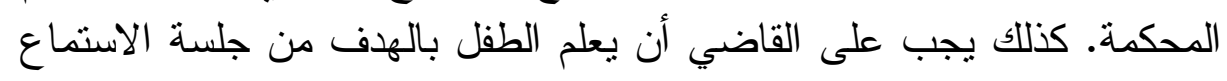
اليه وحدود هذه العملية الإجر ائية.

ولم ينص المشرع على ضمان حق الطفل في الطعن على القرار

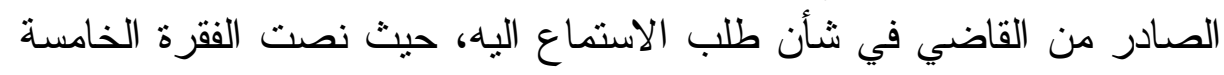

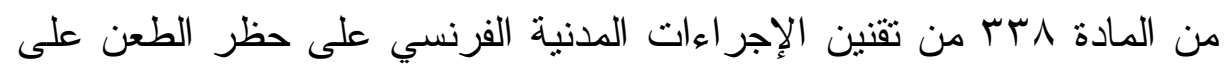

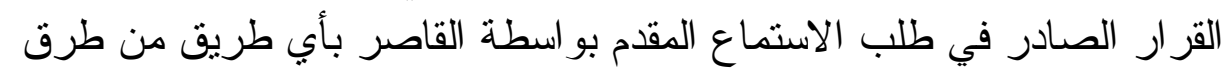
• الطعن

\section{المطلب الر ابع}

\section{القيمة القانونية لر أى الطقل المستمع إليه لاى المحكمة}

يثور تساؤل هام فى هذا السياق يتعلق بالقيمة القانونية لار اء الطفل التى ادلى التى

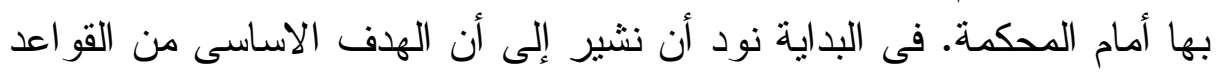
القانوية المتعلقة بالاستماع للطفل فى التقنين الفرنسى يتمثل فى تمكين الطفل

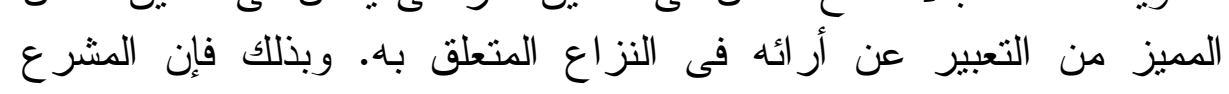

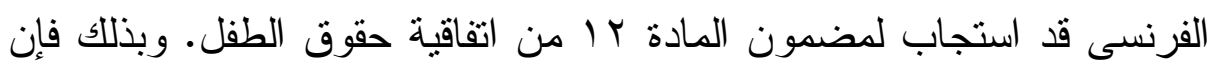

(1) L.Francoz - Terminal, Le nouveau régime de l'audition en justice de L'enfant concerne par une procédure Judicaire, art .prec .p.35.

(2) L.Francoz - Terminal, Le nouveau régime de l'audition en justice de L'enfant concerne par une procédure Judicaire, art .prec.p. 36. 
تحديد قيمة أراء الطفل التى أدلى بها أمام المحكمة يرتبط إرتباط لا يقبل

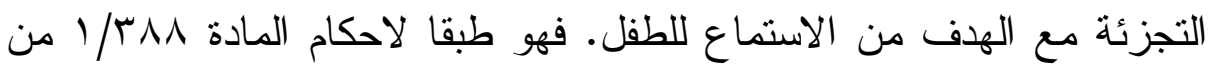

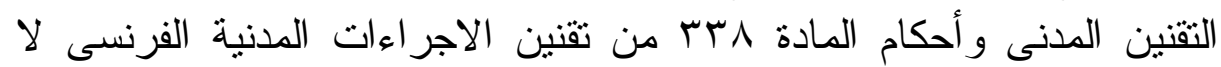

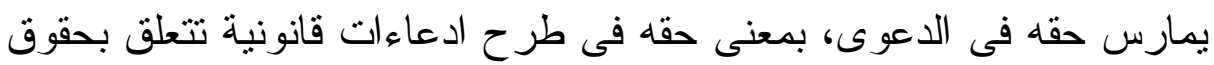

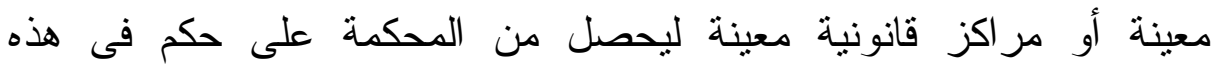

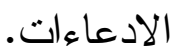

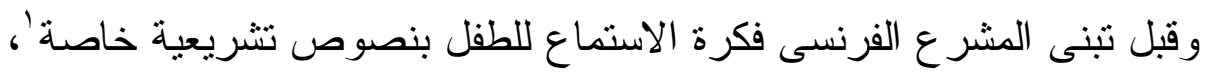

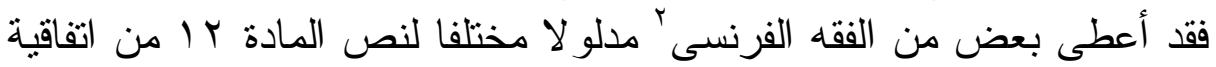

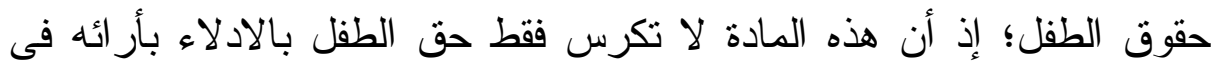

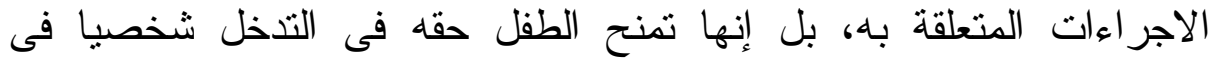

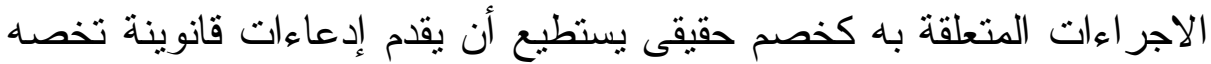
فى الاجر اءات المتعلقة به، وبالتالى فإن الاتفاقية الدولية تمنح أهلية إجرائية

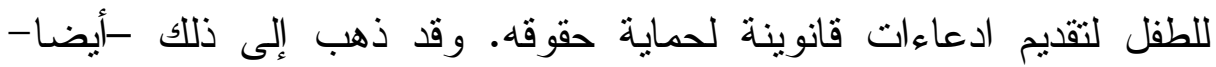

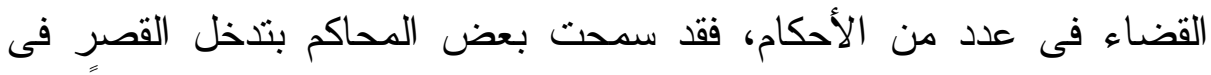

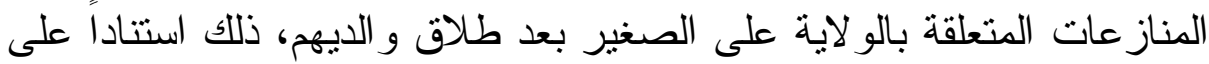

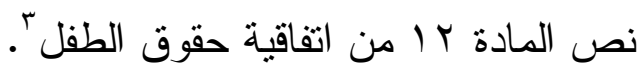

$$
\text { ' ' انظر فى ذلك: }
$$

C.Watine - Drouin, Minorité, audition du mineur en justice, Défense de ses interest, Fasc.unique,op.cit, no 10,p.18.

2 A. Gouttenoire, Colloque "Enfance et justice". Les modes de participation de l'enfant aux procédures judiciaires : Dr. famille 2006, p.29, obs. sous Cass. 1re civ., 15 mai 2005 : Dr. famille 2005, comm. 156., J. M. Bret, La Convention des Nations-Unies sur les droits de l'enfant : Gaz. Pal. 1991, 2, p. 748. - H. Fenaux, obs. : D. 1993, jurispr. p. 179. - O. Matocq, obs. : JCP G 1992, II,p. 21801. - J. RubellinDevichi, Le principe de l'intérêt de l'enfant dans la loi et la jurisprudence françaises : JCP G 1994, I, p.3739.

CA Lyon, 30 avr. 1991, TGI Lille, 14 mai 1991 et CA Paris, 12 juill. 1991 : D. 1992, somm. p. 62, obs. A. Botteau. - TGI Lille, 14 mai 1991 et TGI Lille, 18 juill. 1991, CA Lyon, 30 avr. 1991 et CA Paris, 12 juill. 1991 : D. 1993, jurispr. p. 176, note H. Fenaux.

- CA Lyon, 28 nov. 1991: JCP G 1992, II, 21801, note 
إلا أن هذا التفسير لنص المادة r ا من اتفاقية حقوق الطفل لم ينال تأييد كل

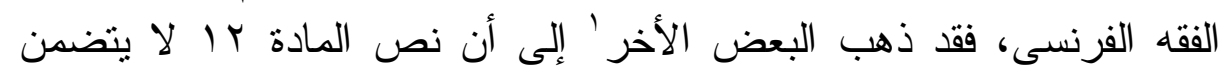

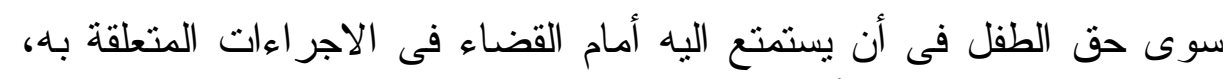

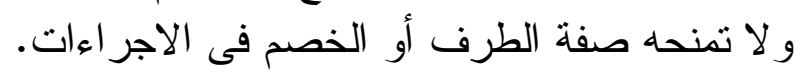

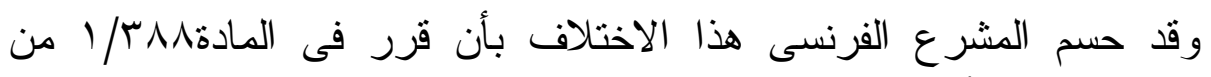

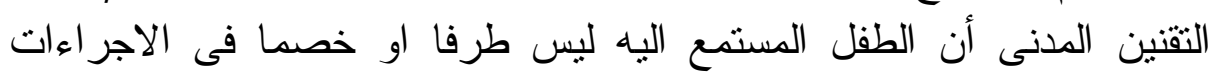

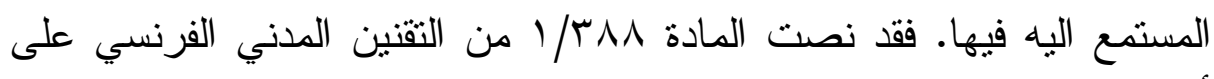

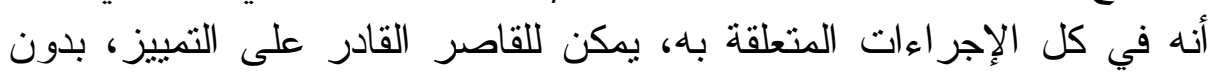

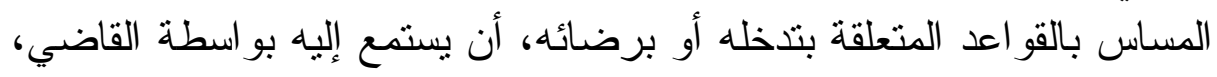

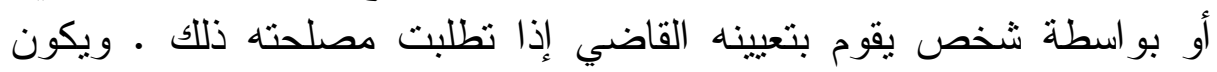

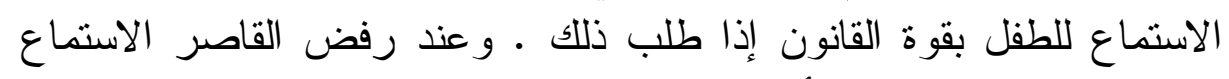

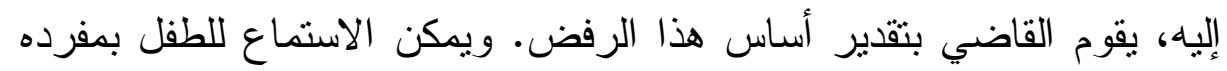

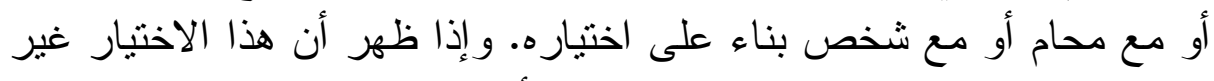

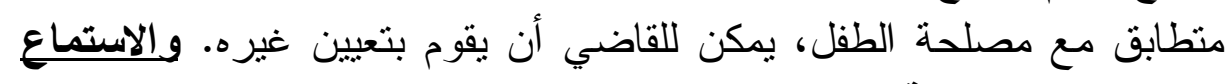
للطقل لا بمنحه صفة الطرف بالإجر اعات.

إذن مضمون حق الطفل فى الاستماع اليه فى الخصومة المدنية المتعلقة به

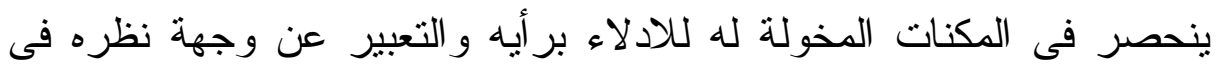

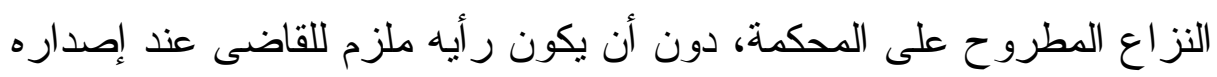

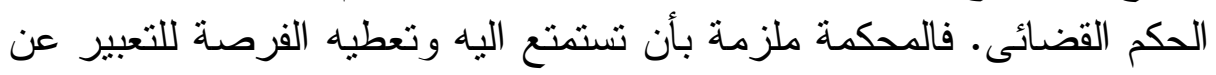

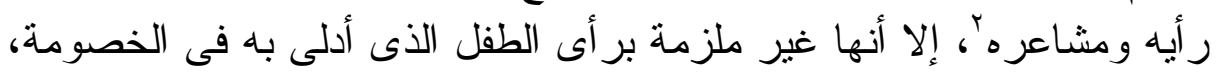

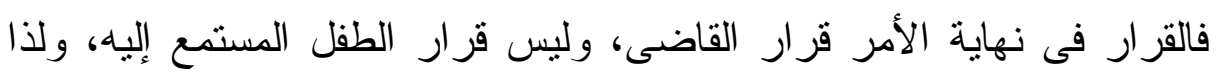

O. Matocq. - CA Versailles, 11 mars 1993 : JurisData $n^{\circ} 1993-$ 041194. - CA Paris, 9 févr. 1993 : JurisData n 1993-020291).

${ }^{1}$ C.Watine - Drouin, Minorité, audition du mineur en justice, Défense de ses interest, Fasc.unique, op.cit. no 10,p.18.

${ }^{2}$ S. Travade-Lannoy, Audition de l'enfant : le point sur les obligations du juge, Gaz.pal. 23 juin $2015 n^{\circ}$ 174, P. 7. M. Douchy-Oudot, L'effectivité du droit de l'enfant à être entendu en droit positif, LPA, 07 octobre $2010 \mathrm{n}^{\circ} 200$, P. 12. 
فللقاضى أن يصدر حكمه مخالفا لوجهة نظر الطفل، فالقاضى هو المقدر

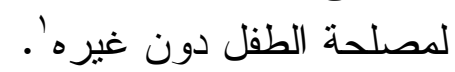

إلا أن ليس معنى ذللك عدم وجود التزام للقاضى عند إصداره حكمه فى في الأنزاع، فقد قررت محكمة النقض الفرنسيةّ ضرورة قيام المحكمة بذكر بيان

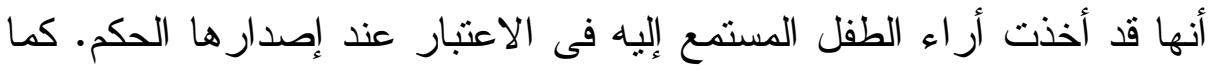
أنها قررت إمكانية قيام المحكمة بتسبيب حكمها على ضوء ر أى الطفل كأحد

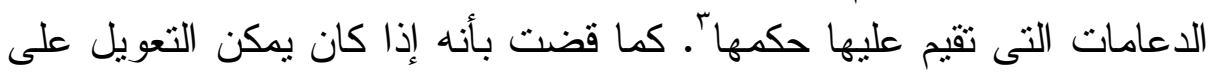
رأى الطفل المستمع اليه فى الحل النهائى للنز اع، إلا انه من غير المقبول قيام المحكمة بتعليق تتفيذ الحكم على إر ادة الطفل، وذلك بأن تقرر فى حكمها حق الو الد فى زيارة طفله بحرية بشرط مو افقة الطفل على ذلكئ.

\section{المبحث الثاني}

\section{المركز الإجرائي للطفل المستمع إليه في الخصومة المدنية}

لم يحدد المشرع الفرنسي المركز الإجرائي للطفل المستمع إليه في الخصومة المدنية، ولم يلق المشرع الفرنسي الضوء على تحديد المركز الإجرائي للطفل المستمع إلبه إلا فيما بتعلق بنفي صفة الطرف عن الطفل

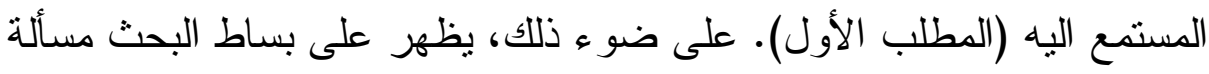
مدي انطباق المر اكز الإجرائية التقليدية على مركز الطفل المستمع إلبه في الخصومة المدنية (المطلب الثاني)، كذلك هل يتمتع الطفل المستمع إلبه بمركز إجرائي خاص في الخصومة المدنية، إذا لم يخضع للمر اكز الإجر ائية التقليدية

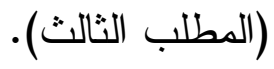

${ }^{1}$ C.Watine - Drouin, Minorité, audition du mineur en justice, Défense de ses interest, Fasc.unique, op.cit. no 27,p.40.

${ }^{2}$ Cass. 1re civ., 20 nov. 1996 : D. 1997, p. 192, note Y. Benhamou, Cass. 1re civ., 8 juin 1999 : Dr. famille 1999, comm. 136, note A. Gouttenoire-Cornut. Cass 1re civ., 20 oct. 2010, nº 09-67468., sur site internet, www.legifrance.com,

3 Cass. 1re civ., 6 mars 2007 : Dr. famille 2007, comm. 145, note P. Murat

4 Cass. 1re civ., 3 déc. 2008 : D. 2009, p. 20, obs. V. Egea. 
العدد الأول- الجزء الأول- السنة الثامنة والخمسون- يناير 17.r =

$$
\text { المطلب الأول }
$$

نفي مركز الطرف (الخصم )عن الطقل المستمع إليه في الخصومة المدنية الفرع الأول

\section{نفى صفة الخصم بصفة عامة}

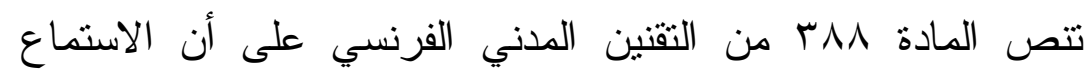

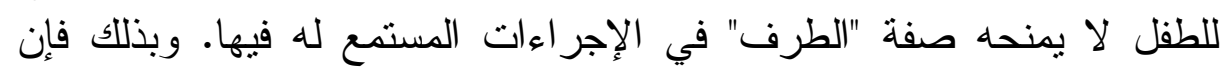

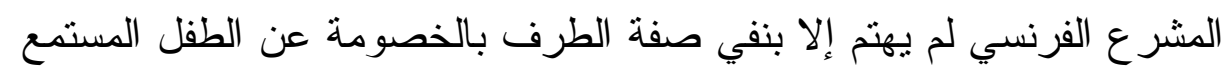
إلبه فيها.

إن موقف المشرع الفرنسي يجد منطقه في أن الطفل المستمع إليه في

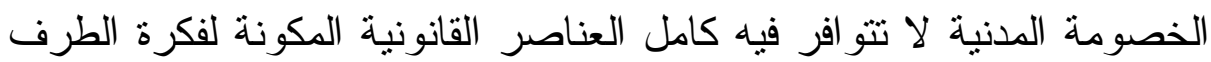

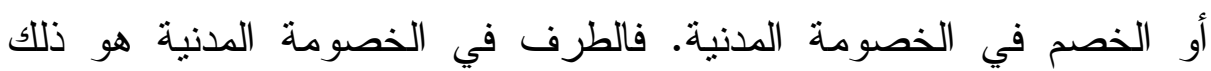

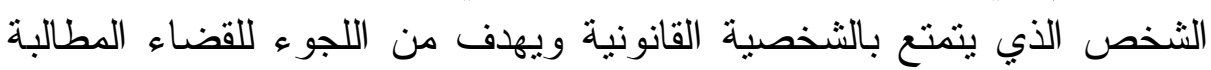

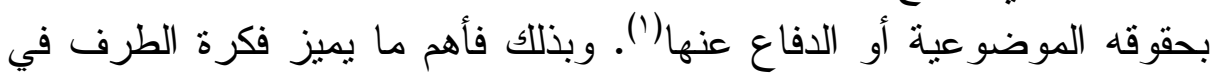
الخصومة المدنية قيام الثخص في الخصومة المدنية بالمطالبة القضائية طبقا

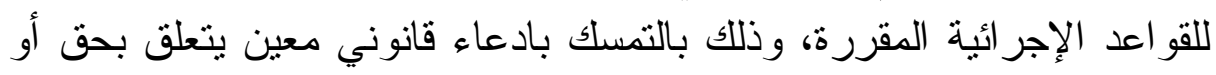
مركز قانوني معين.

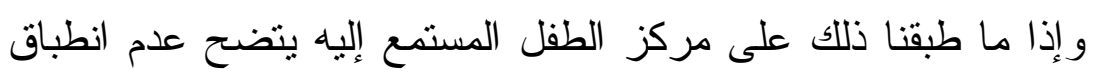
فكرة الطرف في الخصومة على الطفل المستمع اليه. فالطفل المستمع إليه لا لإنه يتقدم بطلب في الخصومة بهدف الحصول على حكم من المحكمة في

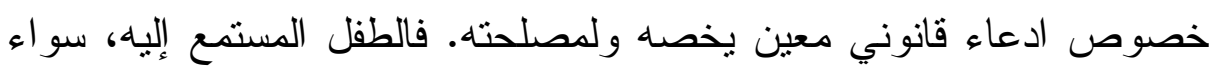

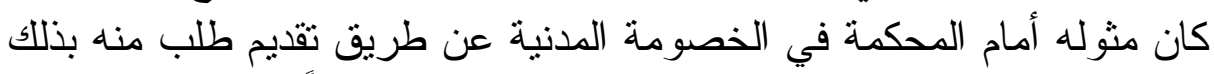

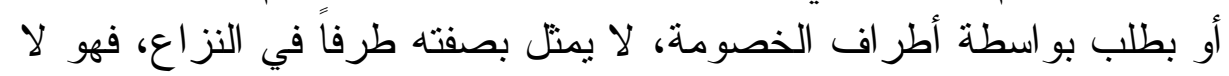
يدعي بحق معين يخصها أو يدافع عن حق معين يخصهاه.

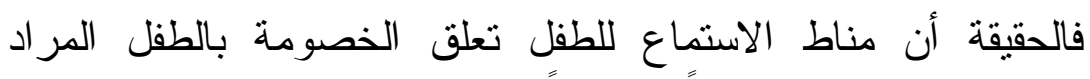

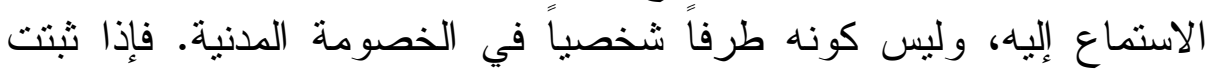

$\left({ }^{1}\right)$ B. Kornsprobst, La notion de partie et le recours pour excès de pouvoir, thèse, Paris 1959 : LGDJ, p. 12, P.chevaleir, Parties à l'instance, Jur.Class.civ. 2010, Fasc.105, n 3.p.7. 
للطفل الصفة في الدعوي، فإن مثوله في الخصومة سيكون عن طريق ممثلك

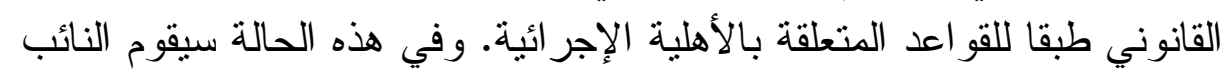

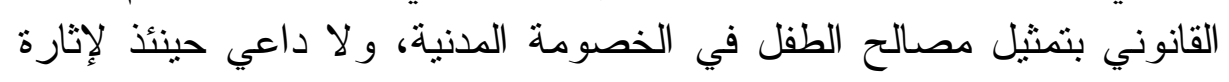

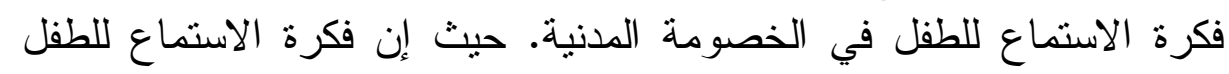

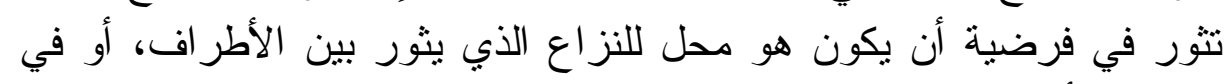

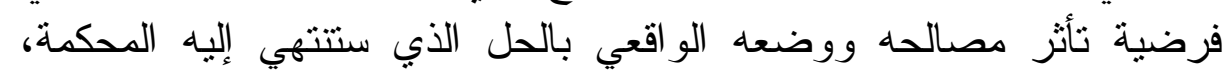

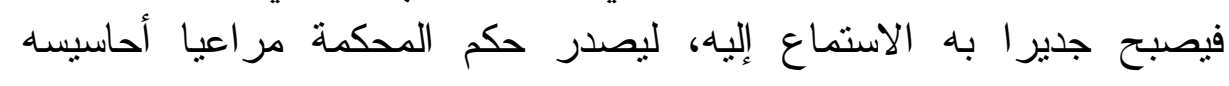

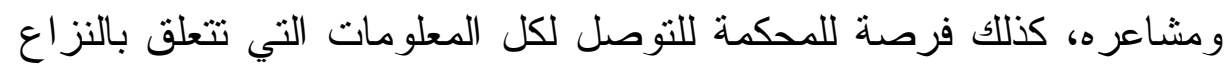
المعروض عليها.

\section{القرع الثاني}

\section{نفى صفة الطرف المتدخل أو المُدخل في الخصومة}

و لا يكتسب الطفل المستمع إليه في الخصومة المدنية صفة المتدخل في الخصومة، أيا كان نوع التخخل (') فلا يعد الطفل المستمع إليه متخخلاً هجوميًا intervention attaqué

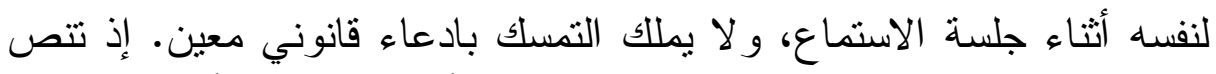

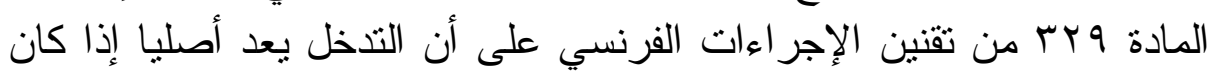

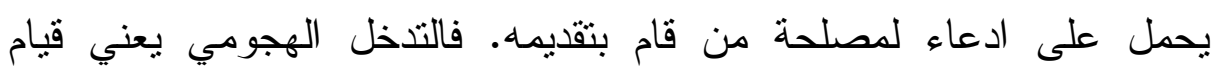

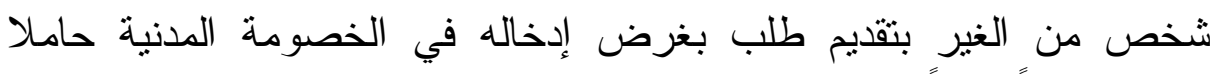

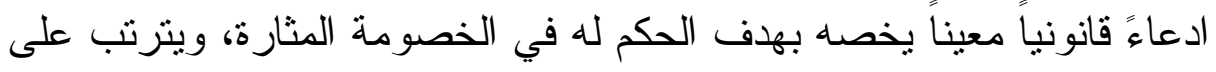

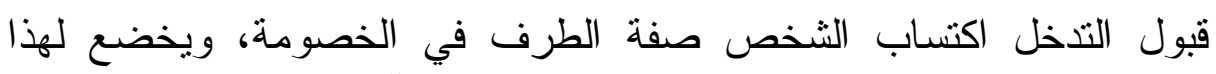

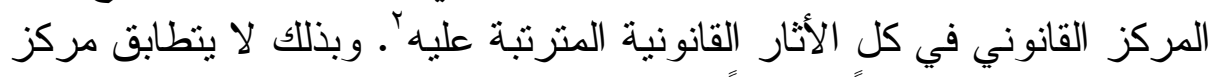

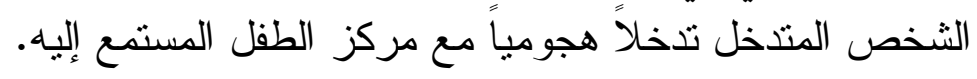

( $\left.{ }^{1}\right)$ J.-J. Taisne, Intervention, Juris-Class. Proc.civ.2013, Fasc. 127$1, \mathrm{n} 1 \mathrm{p} .1$ et $\mathrm{s}$.

${ }^{2}$ H. Croze, C. Morel, O. Fradin, Procédure civile: LexisNexis, coll. Objectif Droit 2008, $4^{\text {e }}$ éd., n 390,P.350., S.Guinchard, C.Chainais, F.Ferrand, Procedure civile, droit interne et droit de 1 Union europeenne, Dalloz, 2010,30 ed., n 309,p.275 


\section{ولا يكتسب الطفل المستمع إليه صفة المتخخل بصفة انضمامية}

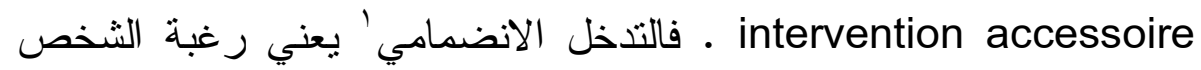
الانضمام لأحد الأطر اف الأصليين في الخصومة، سواء بهدف تدعيم ادعاءاته فئه

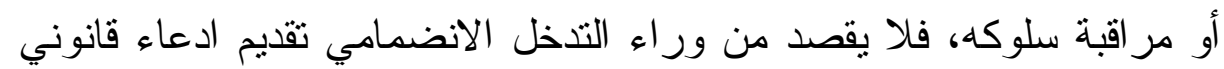

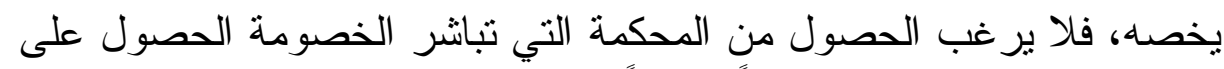

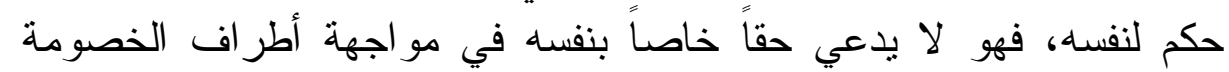
الأصليين، إلا أنه تثبت لله مصلحية شخصية في الخصومة، مرتبطة بمصلحة

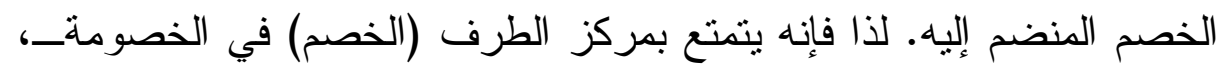

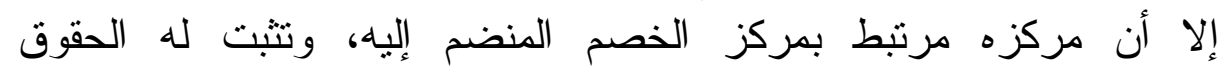
و الالتز امات على ضوء مركز الأخير ، أو ما يمكن تسميته بالخصم التابع.

و يتشابه مركز الطفل المستمع إليه مع مركز المتدخل تدخلاً انضمامياً

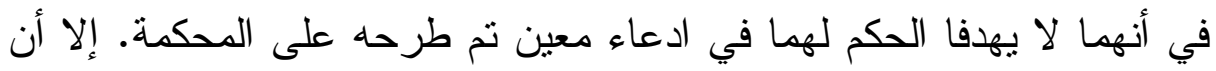
مركز كليهما يختلف على ضوء أن الهدف من إجر اءات الاستماع للطفل إتاحة

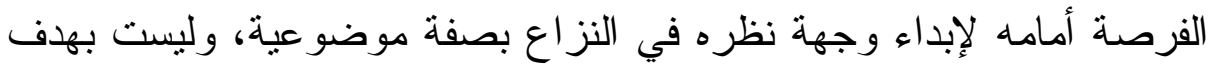

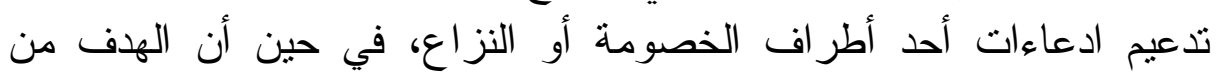

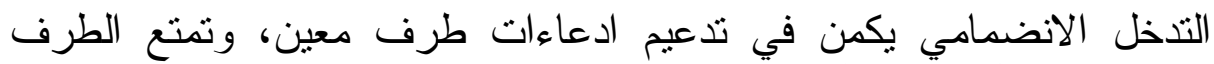

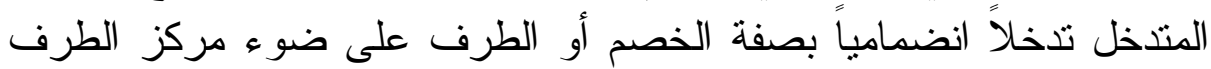

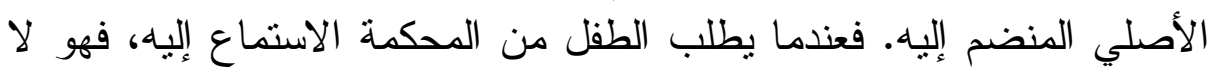

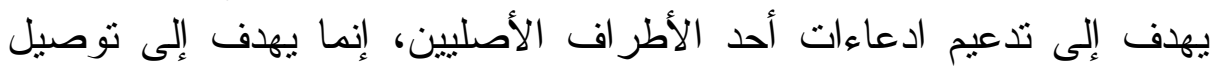

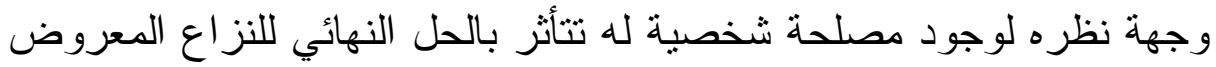
على المحكمة.

كذللك لا يتطابق مركز الطفل المستمع إليه مع مركز الثخص الذي الذي الثيا

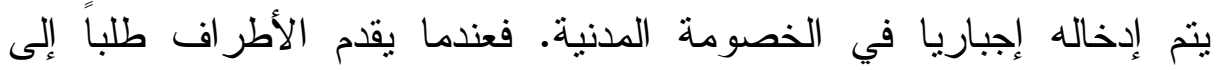

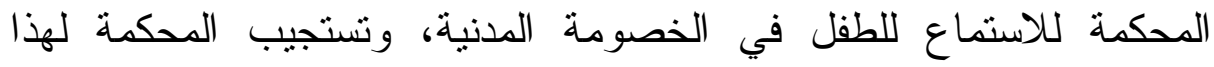
الطلب، فلا يعتبر ذلك إدخالا لخصم في الخصومة. كما أنه إذا طلبت المحكمة الاستماع للطفل من تلقاء نفسها، فلا يكتسب الطفل صفة الخصا لخص.

${ }^{1}$ S.Guinchard, C.Chainais, F.Ferrand, Procedure civile, droit interne et droit de 1 Union europeenne, op.cit.n 311,p.275. 
إذ أن الإدخال الإجباري يعني إكساب شخص من الغير صفة الخصم رغما عن إر ادته وذللك إما بناء على طلب أحد الخدي الخصوم في خصومة فئ قائمة

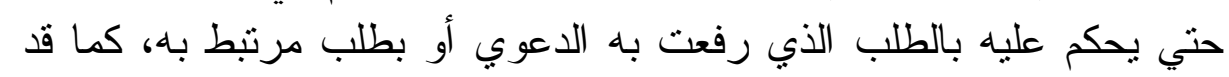
يكتسب صفة الخصم بناء على أمر المحكمة بإدخاله.

إذ تختلف فكرة الاستماع للطفل بناء على طلب الأطر اف عن فكرة

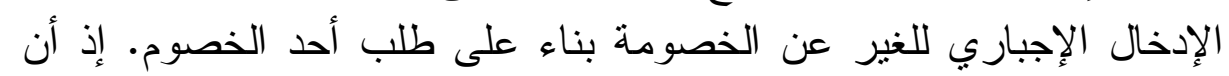

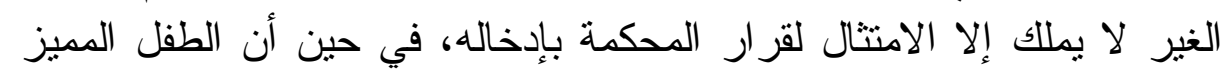

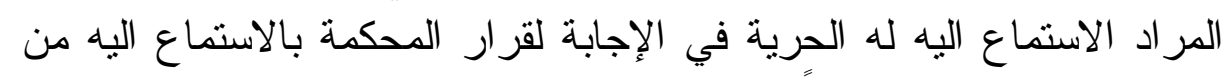

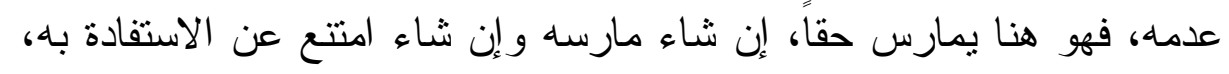

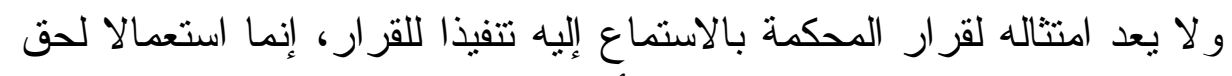

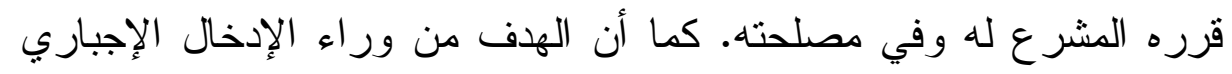

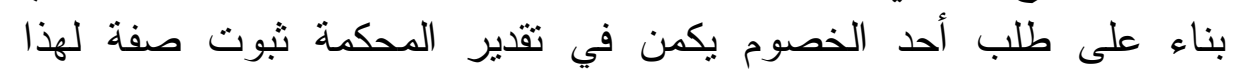

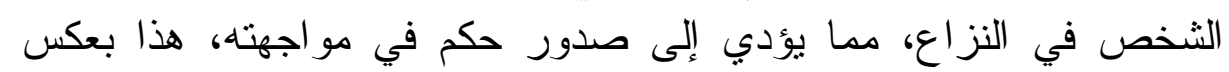

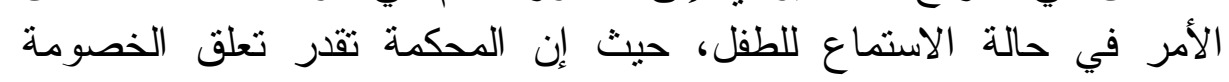

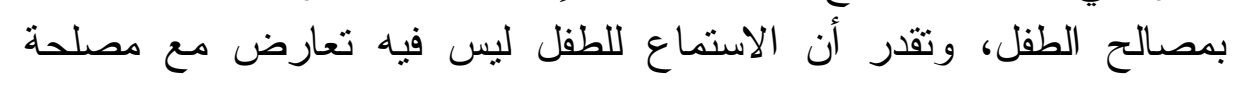

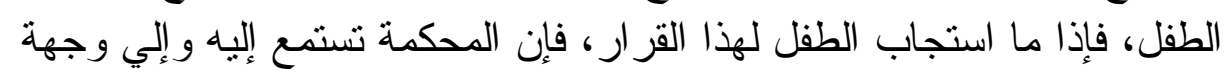

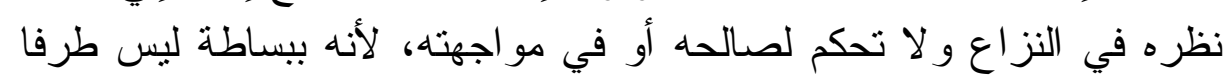

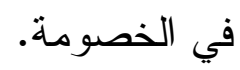

و لا بعتزف القانون الفرنسى بفكرة اختصام الغير بواسطة المحكمة

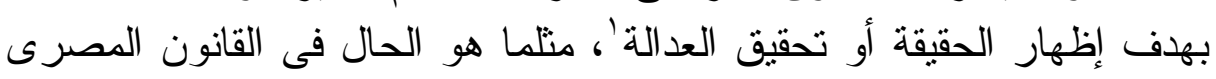

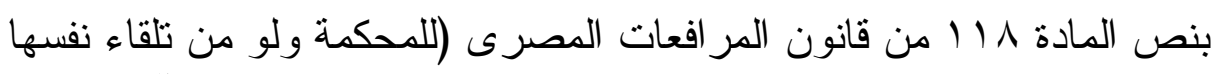
أن تأمر بإدخال من نزى إدخاله لـصلحة العدالة أو لإظهار الحقيقة) '.

1 Cass. 3e civ., 12 juill. 1977 : Bull. civ. 1977, III, n 311 ; RTD civ. 1978, p. 424, obs. R. Perrot.

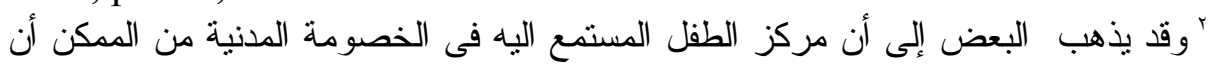

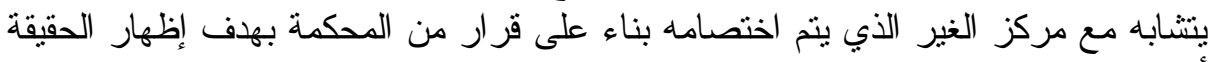

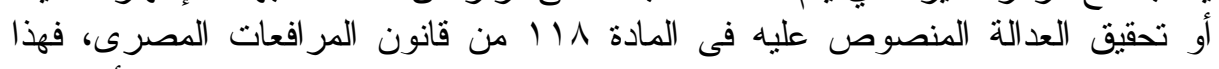

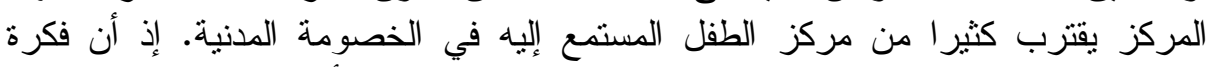

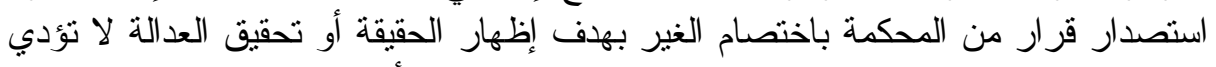

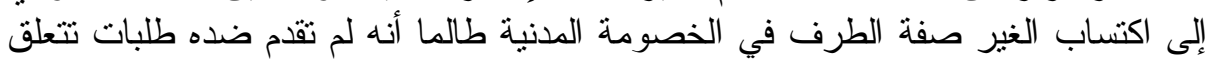




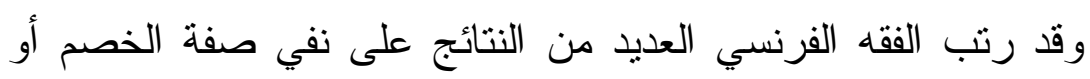
الطرف في الخصومة عن الطفل المميز المستمع إليه. فالطفل المستمع إلبه فيه

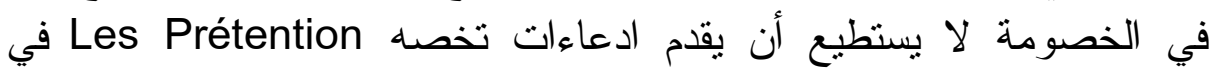

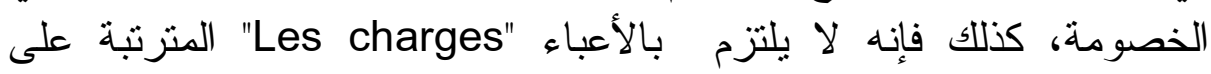

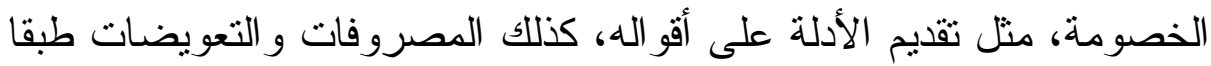

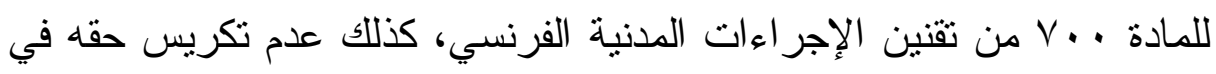

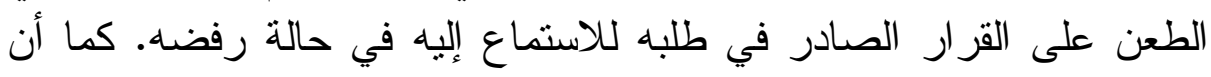

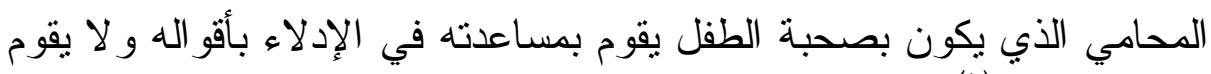
بتمنيله إجر ائيا (')

و إذا كان الطفل المستمع إليه في الخصومة المدنية لا يتمتع بصفة الطرف في الخصومة المدنية فهل يمكن إخضاع هذا المركز لمركز إجرائي أخر قريب منه.

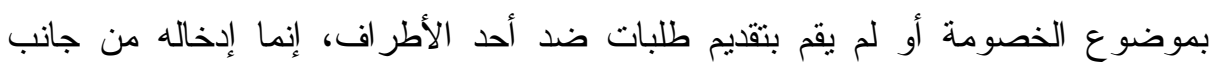

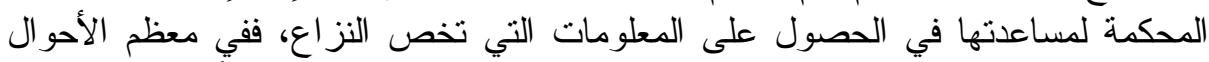

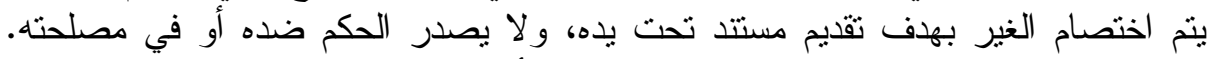

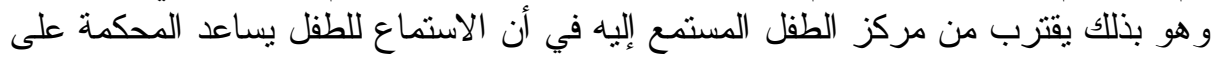

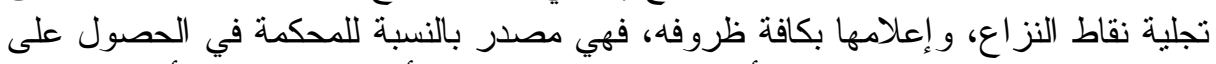
معلومات تخص النزاع، فلا شك أن الاستماع اللطفل يمكن أن يظهر الحقيقة أو يساعد في لئي تحقيق العدالة. إلا أنه رغم ذلك، فإن مركز الطفل المستمع إليه يختلف عن مركز الغير الذي نم إدخاله

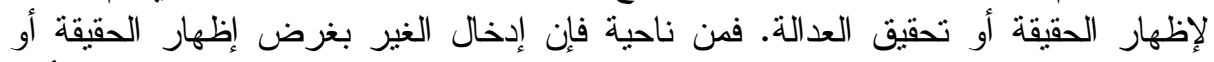

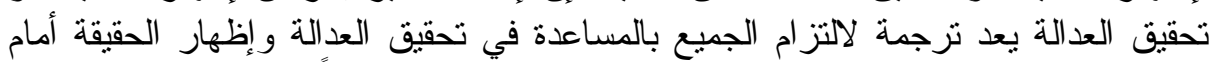

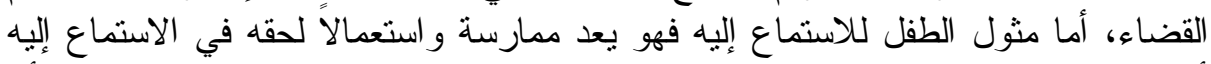

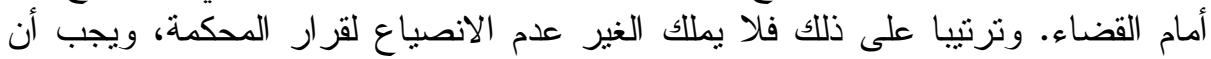

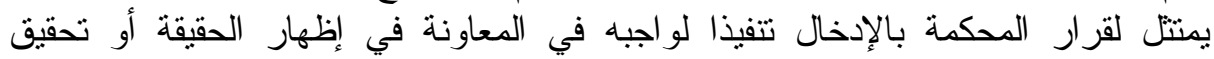

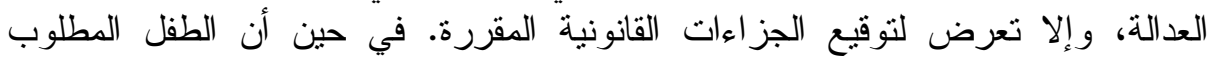

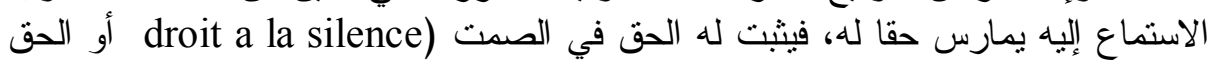

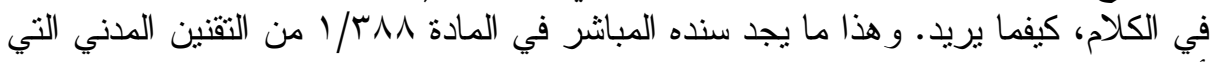

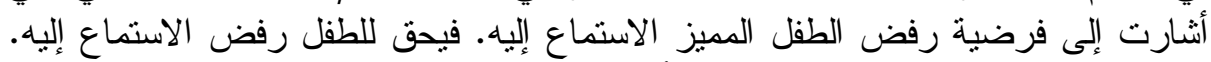

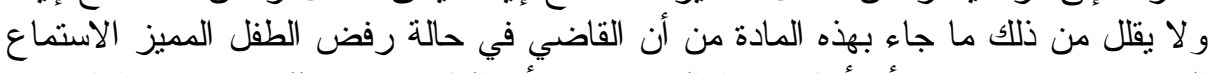

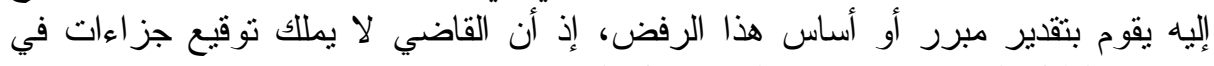
مو اجهة الطفل الر افض الاستماع إليه في كل الحالات.

(1) R. Martin, l'audition du mineur en justice, op.cit. n 65. 
العدد الأول- الجزء الأول - السنة الثامنة والخمسون- يناير 19.

\section{المطلب الثاني \\ مدى خضوع الطفل المستمع إليه \\ إلي المراكز الإجرائية التقليدية في الخصومة المدنية}

يثور في هذا السياق تساؤل منطقي مفاده مدى خضوع مركز الطفل

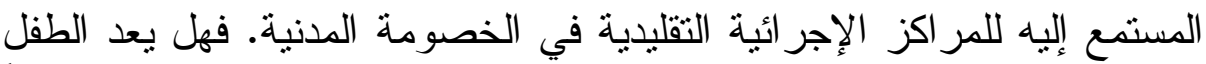

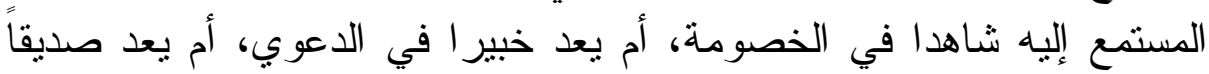

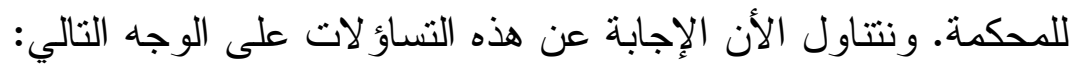

\section{القرع الأول}

\section{مدى انطباق مركز الشاهد على مركز الطقل المستمع إليه}

يثور تساؤل مفاده هل الطفل المستمع اليه يخضع لفكرة الثاهد في

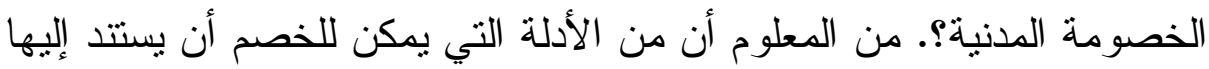

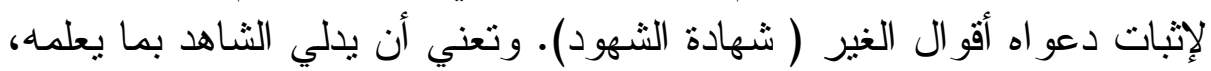

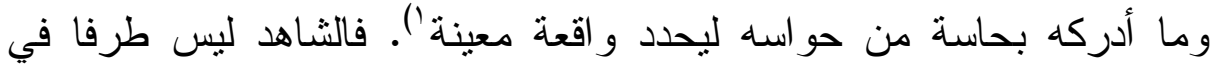

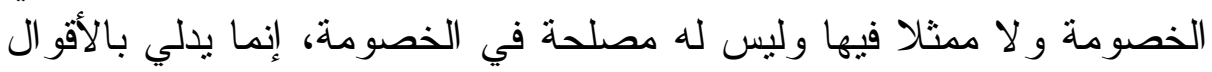

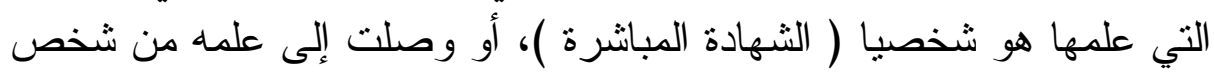

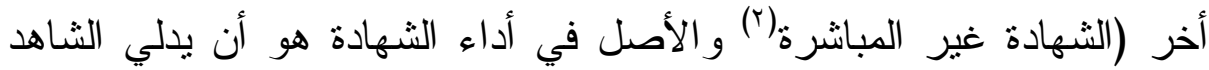
بأقو اله شفاهة أمام القضاء بعد القباء حلف اليمين.

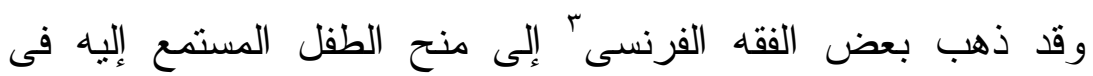

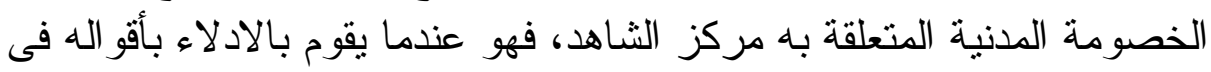

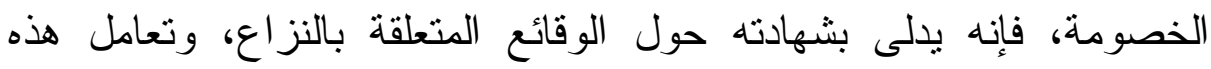
الأقوال معاملة الثهادة، وتعد النصوص لثانه المنظمة لعملية الاستماع للطفل

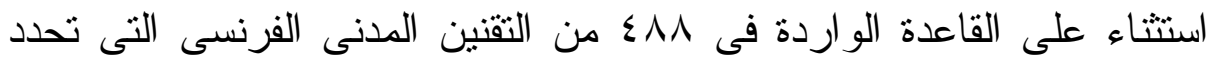
سن الثهادة بثمانى عشر عاما.

(') G. Hubrecht, Droit civil, Dalloz, 1993,p.144

د. عبد الرزاق السنهوري، الوسيط في شرح القانون الددني جن الاثبات، دار

3 M. Oudin, Contrats et obligations. - Preuve testimoniale. Généralités Jur.Class. Civil Code, Art. 1341 à 1348, 2014, n 25, p.42. 


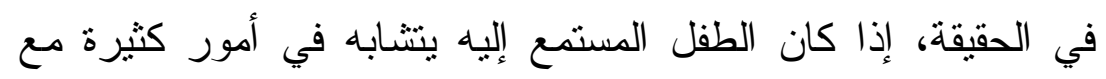

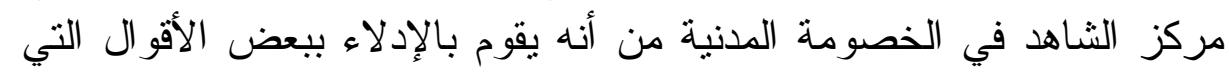

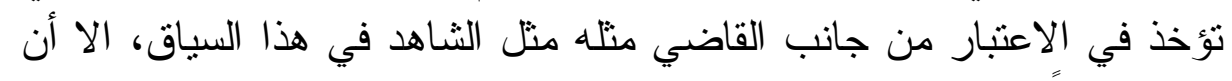
هنالك فروقاً جو هرية بين مركز الطفل المستمع إليه و الثـاهد.

حيث إن أساس قبول الثهادة أمام القضاء عدم وجود مصلحة للشاهد

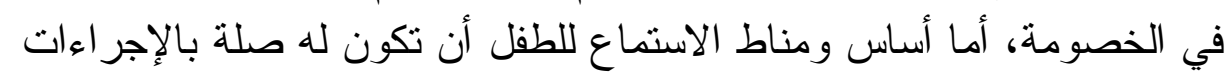

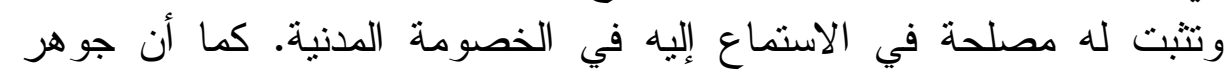

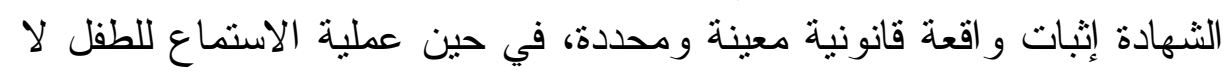

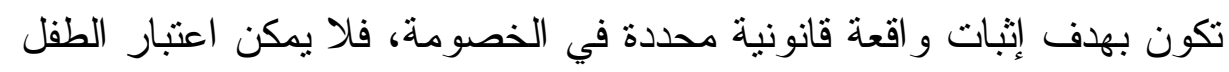

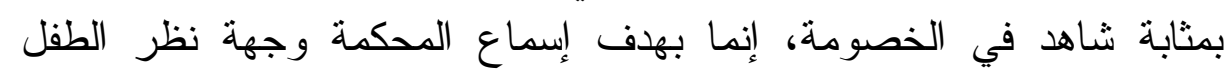

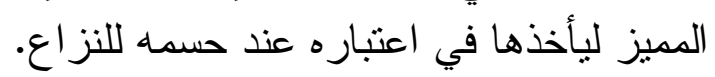

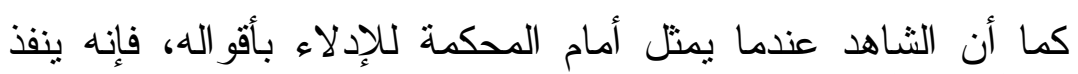

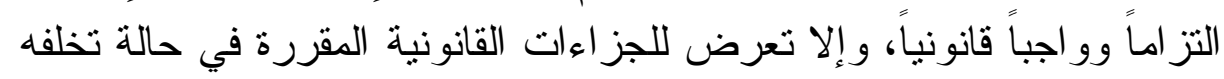

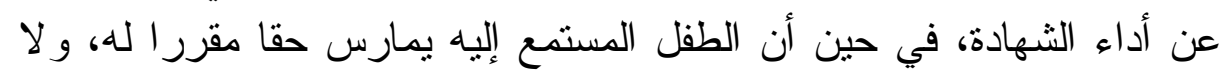

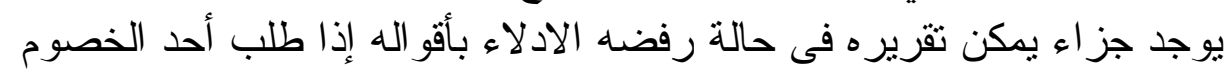
إلاستماع اليه. فالطفل لله حرية ممارسة حقه فيه في الاستماع اليه إليه من عدمه.

\section{الفرع الثاني}

\section{مدي انطباق مركز الخبير على مركز الطقل المستمع إليه}

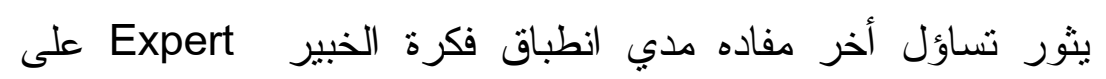

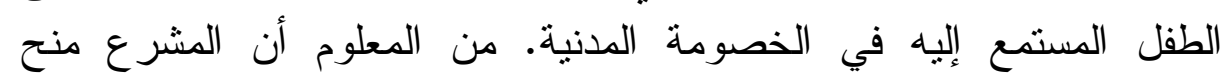

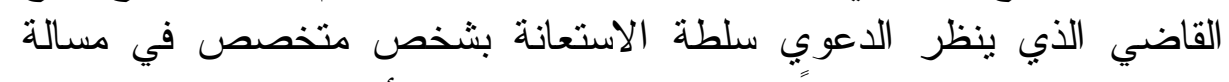

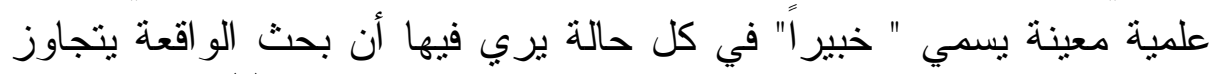

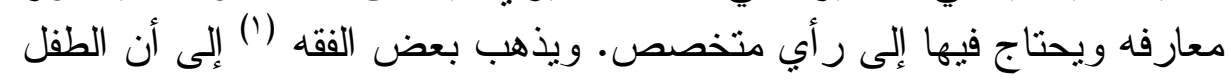

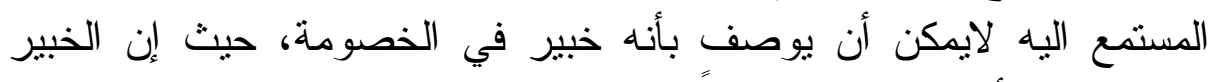

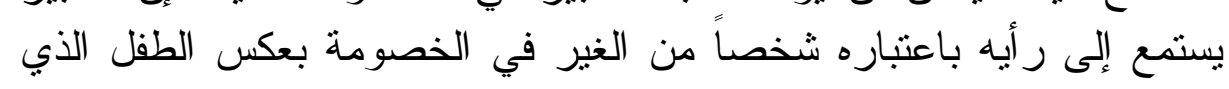

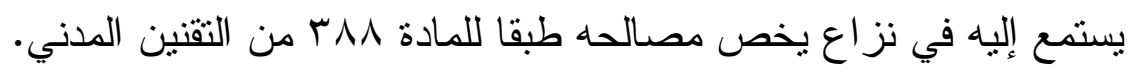

(1) R. Martin, Audition de mineur en justice, op.cit.. n 67. 
وبالإضافة لذلك يمكن القول بأن الخبير يلتجأ اليه بقصد نقديم تقرير

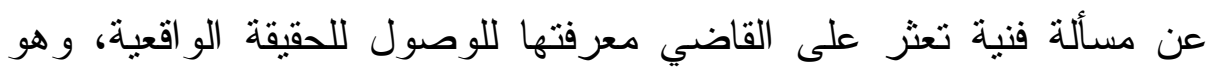

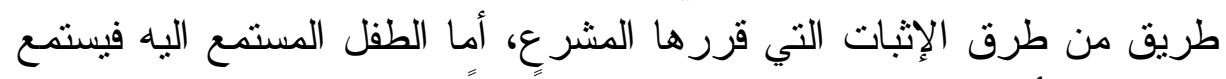

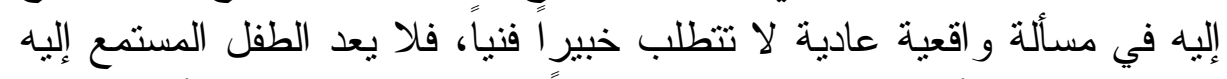

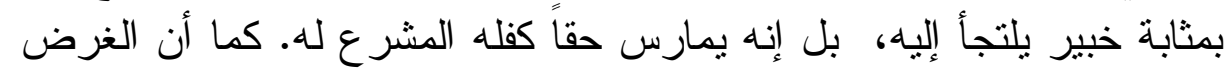

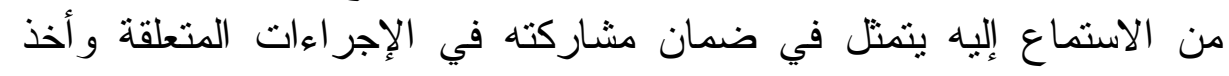

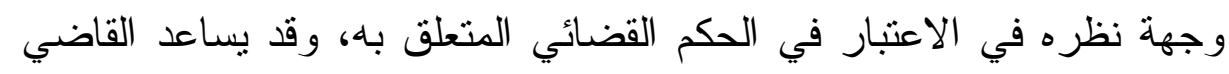

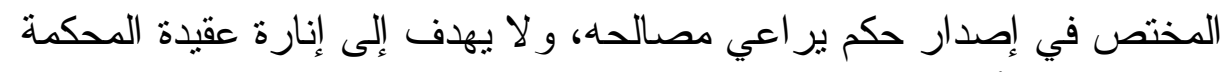

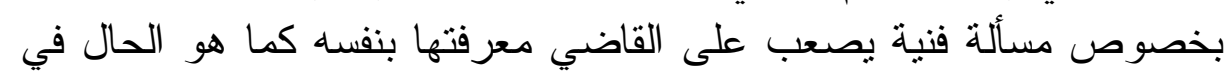

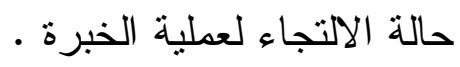

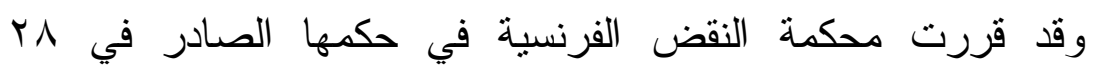

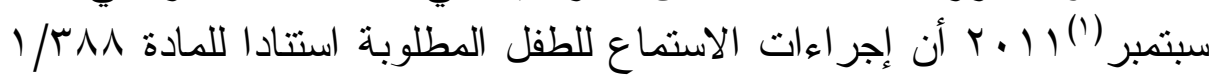
من التقنين المدني لا تخضع للنظام المطبق على الخبرة.

\section{الفرع الثالث}

\section{مدي انطباق فكرة صديق المحكمة على الطقل المستمع إليه}

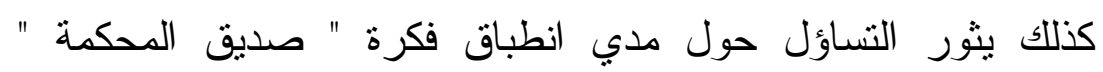
"L'amicus Curiae ""

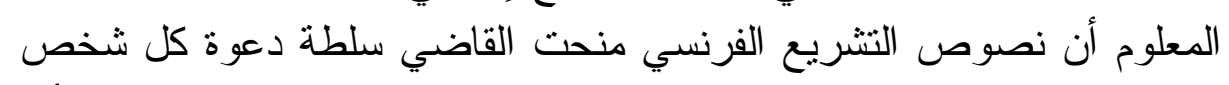
يري سماعه مفيدا في إظهار الحقيقة، وبذلك يمكن للقاضي الاستعانة بأي ماتي

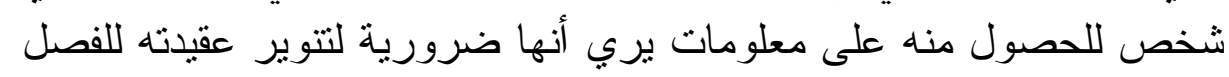

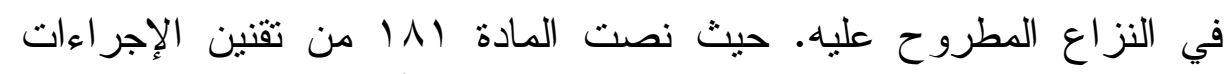

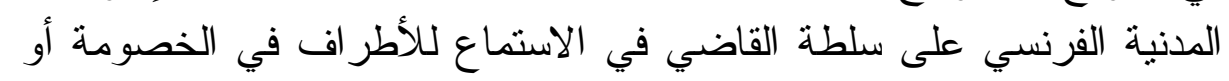

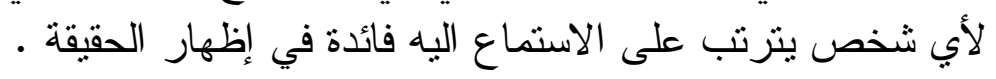

(1) Cass. Ire. Civ. $2 \wedge$ sept.2011 ,Revue Juridique de la personne et de la famille, 2011, p.12 . obs.f.Eudier. 
وتطبيقا لذلك قامت محكمة النقض بدعوة شخصية ذات مكانة رفيعة

في المجتمع لتستوضح منها بعض الأمور المتعلقة بالطعن المعروض عليها. ودعت هذه الثخصية بصفتها صديق المحكمة (1) .

و هذا النظام بستقي مصدر ه منٍ الدول ذات النظام الأنجلوسكسوني .

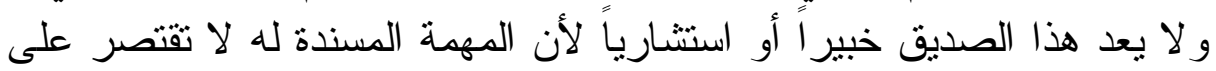
المسائل الو اقعية الفنية البحتة، بل تمتد لتشمل المسائل القانونية. و لايعد - المدئل أيضا- شاهدا لأنه يقدم إيضاحات ويبدي رأيه الشخصي يحدد مسألة معروضه للفصل فيها من أجل إظهار العدالة لا من أجل إثبات الواقعة المتتاز ع فيهاب(؟). و الر أي الر اجح في الفقه الفرنسي يذهب إلى أن صديق المحكمة لا بخر ج عن كونه استشاريا متميز اله مو اصفات خاصةCConsultant privilégie، تسمح المحكمة أن بدلي برأيه، وتقديم مشورته دون الخضوع للقو اعد المتعلقة و المتبعة عند ندب فني technician، كما أن هذا الاستشاري بدلي برأيه في مسائل قانونية مع ضرورة احتر ام ومر اعاة مبدأ المو اجهة(r).

ومن خلال ما تقدم يظهر أن مركز الطفل المستمع إلبه في الخصومة المدنية لا يمكن أن يفسر من خلال فكرة صديق المحكمة. حيث يفترق مركز

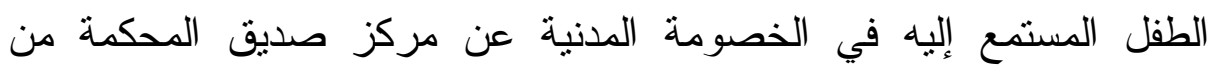

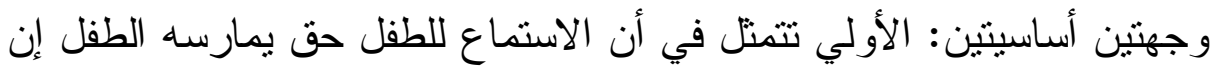
شاء استعمله و إن شاء رفض استعماله. في حين أن الاستعانة بصديق المحكمة

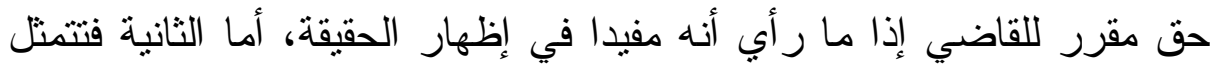
في أن قبول الاستماع لصديق المحكمة بفتزض ألا نكون له مصلحة في النز اع المعروض على المحكمة، في حين أن قبول الاستماع للطفل بعتمد في الأساس

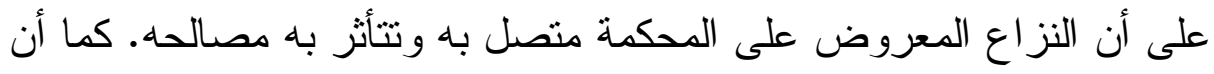
قبول الاستماع للطفل يمكن أن يكون أمام محكمة أول درجة وثاني درجة و لا

$$
\text { (1) انظر في ذلك }
$$

Y. Laurin, la consécration de l'amicus curaie " devant la cour de cassation, Gaz. Pal. 15 juin 1991, 1, doct . p.138.

(Y) انظر د. سحر عبد الستار، دور القاضي في الاثبات، رسالة جامعة عين شمس،

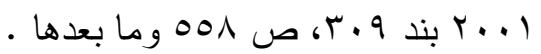

(3) F. Terre. J. C. P. 1991. Obs. sur Cass. Plen. 31 mai1991. Juris .11 .4 IVOY 
يمكن أن يكون أمام محكمة النقض، اما صديق المحكمة فيمكن استدعاؤه في

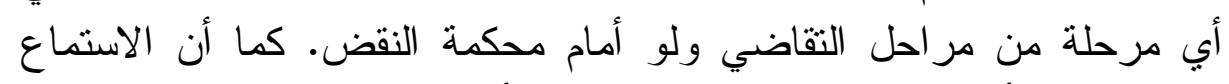

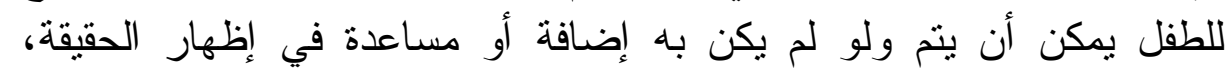
فبمجرد ثبوت قدرة الطفل على التمييز وأن الإجر اءات تتعلق بـه، يثبت للطفل

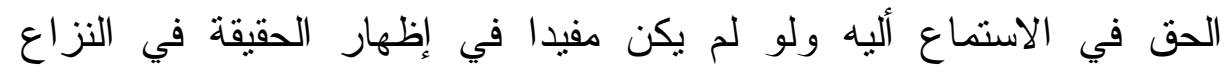
المعروض على المحكمة.

\section{المطلب الثالث}

\section{نحو تحديد مركز الطقل المستمع إليه في الخصومة المدنية}

إزاء عدم خضوع الطفل المستمع إليه لفكرة الطرف (الخصم) في

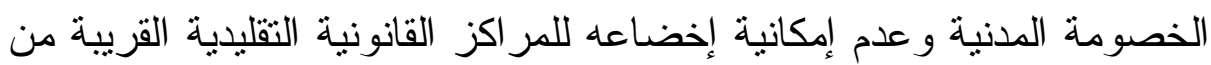
هذا المركز، يصبح من الضروري تحديد المركز القانوني للطفل المستمع إليه.

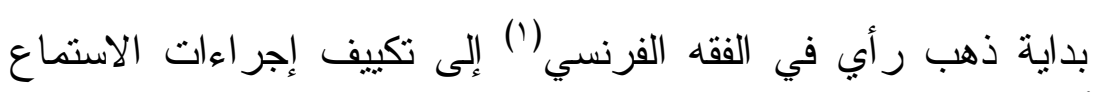

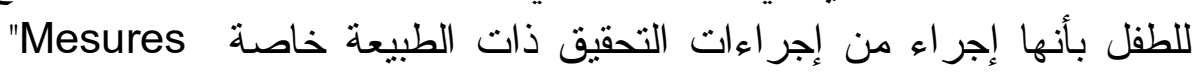
d'instruction particulière" بقرار من القاضي بهدف الحصول على المعلومات الضرورية لإعلام القضاء

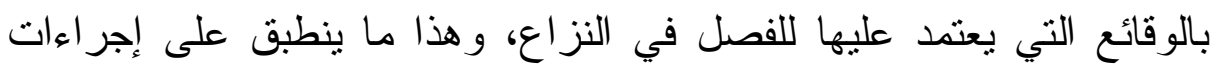

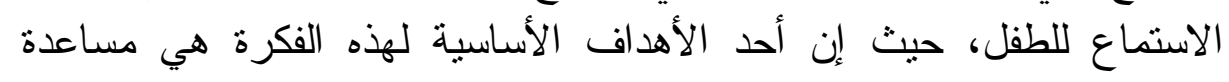

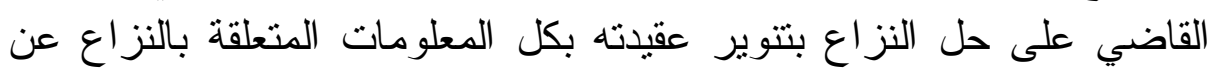

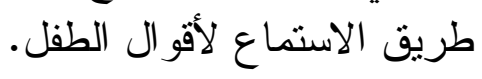

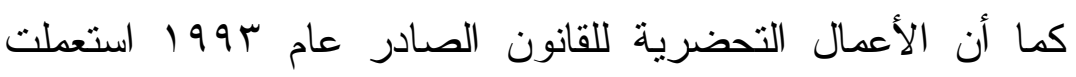

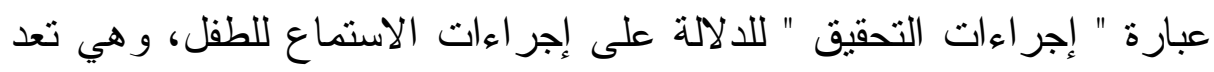

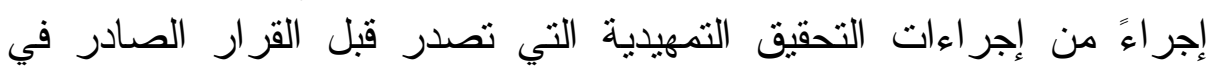

( $\left.{ }^{1}\right)$ L. Cadiet, E. Jeuland, Droit Judicaire prive : Litec. 5ed .2006, n 604, p.470. J. Massip, les modifications apportees au drait dela famille par la loi du 8 Janvier1993: Defrenois1993, art . 35569. P673 ets. 
الموضوع. وبناء على ذلك فإن هذه الإجراءات تخضع لاختصاص قاضي (') Le juge de la mise en état التحضير

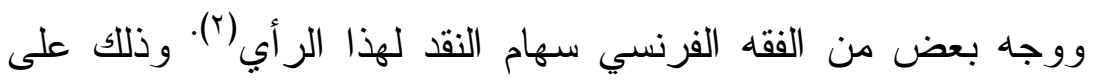

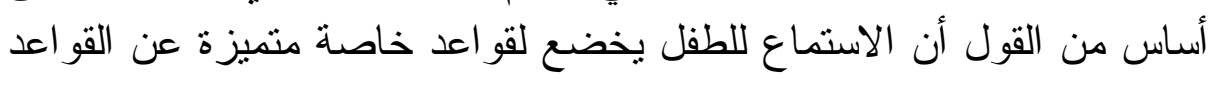

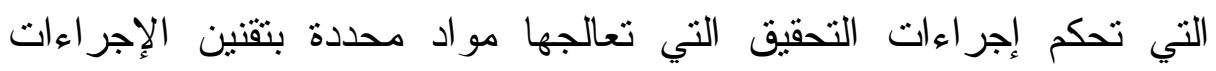

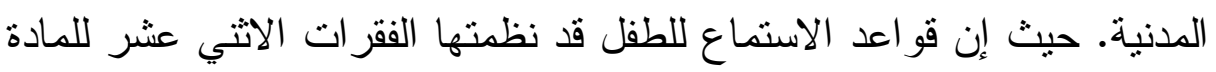

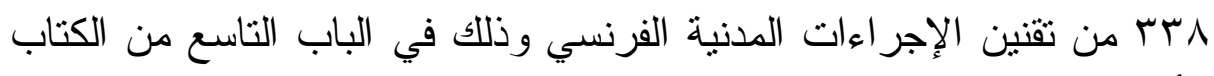

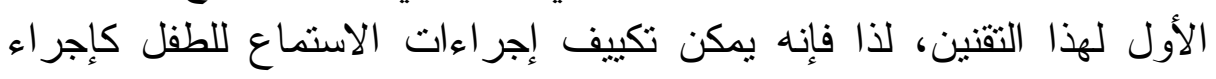

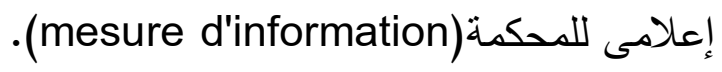

ويذِهب رأي في الفقه الفرنسي (r) إلى أن مركز الطفل المستمع إليه

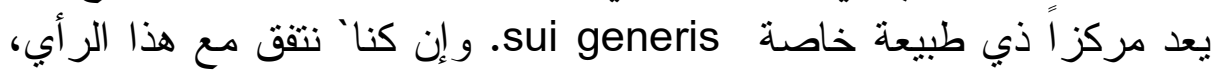

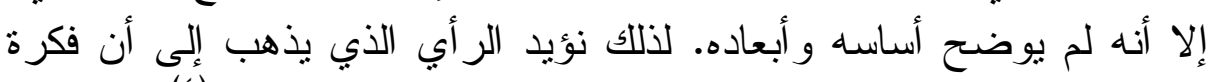

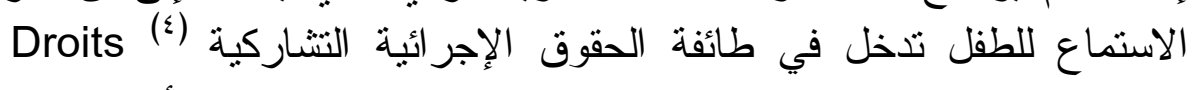
participatifs و التي تكرس فقط للطفل المميز دون غيره من الإنة الأطفال بقصد

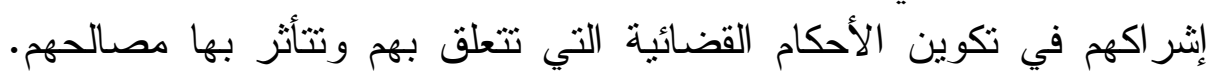

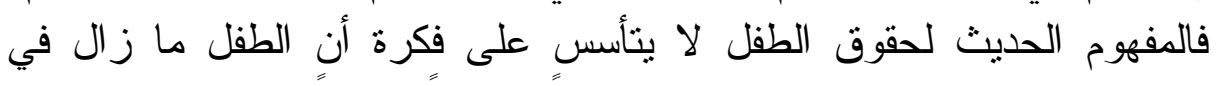

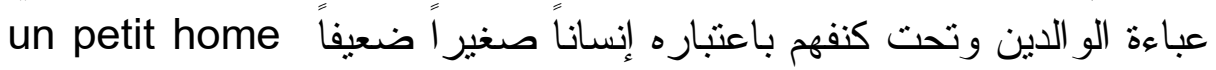
fragile

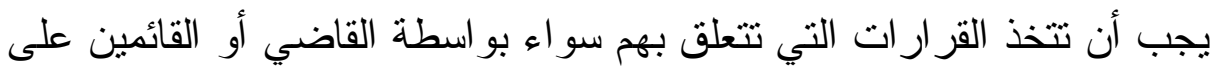

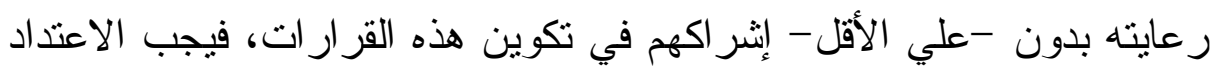
بإر ادتهم في القرار ات التي تخصهم، خصوصا الأنسر الأحكام القضائية.

(1) CA. Angers, 30 Nov. 2005: Juris- data n 20052930. www.Legifrance.fr.

$\left({ }^{2}\right)$ C. Watine - Drouin, Audition du mineur en justice, op. cit.. n 32.

$\left({ }^{3}\right)$ J. R Demarchi, Une justice familiale en mutation, LPA, 17 mars 2010, n 54 p.5 .

$\left({ }^{4}\right)$ A. Gouttenoire, Le statut de l'enfant depuis la convention internationale relative aux droits de l'enfant, Rev. Lamy Droit Civil, 2005, p.18. 


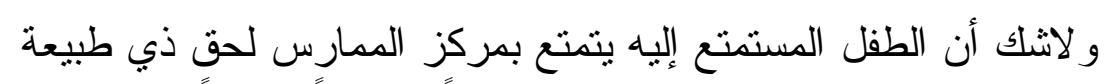

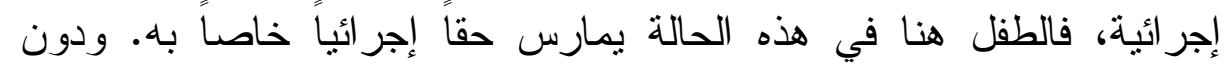

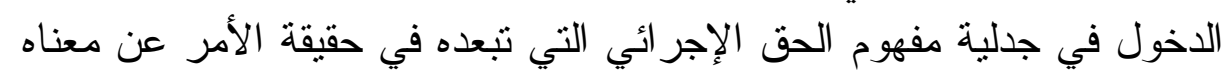

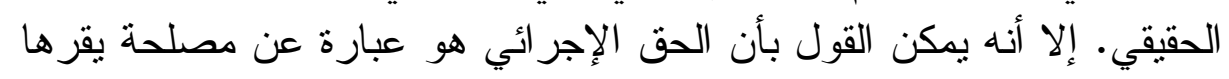

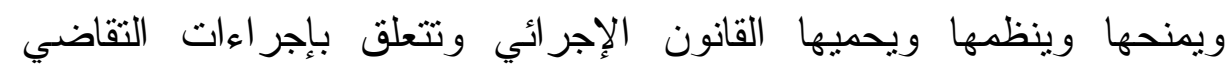
بالمفهوم الو اسع للكلمة.

وباعتبار أن القاعدة الإجرائية هي تلك القاعدة التي تتشئ وتتظم

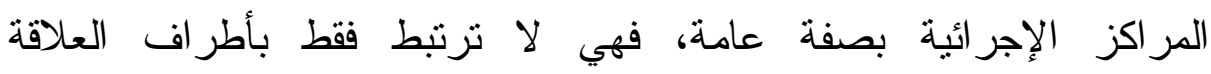

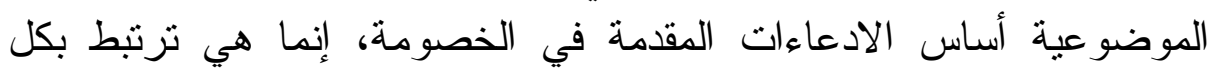

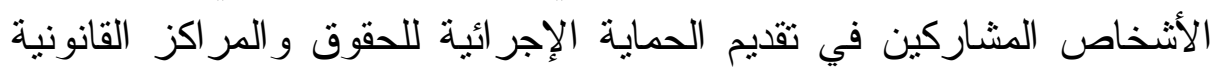

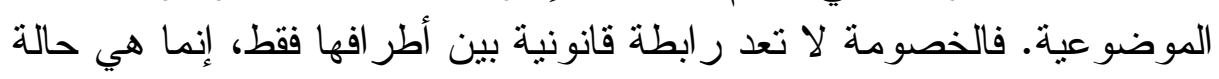

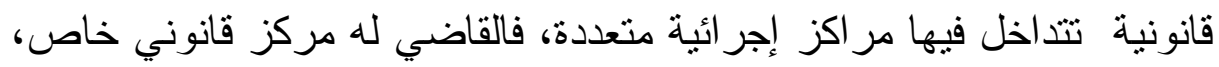

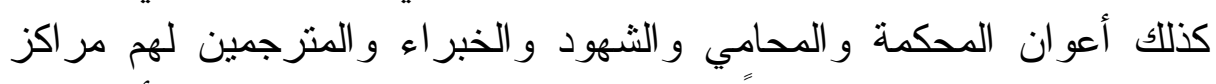

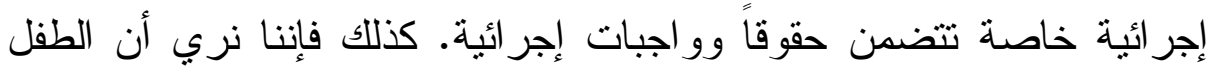

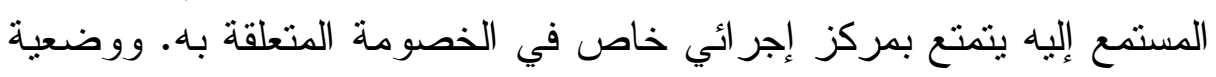

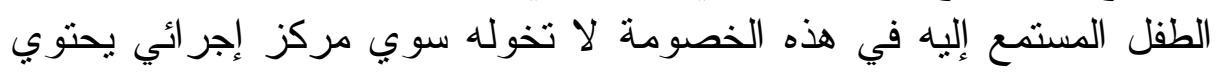

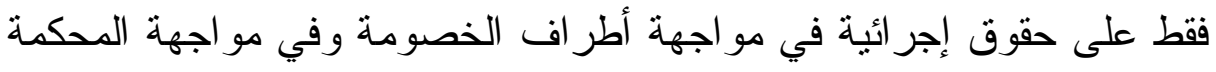

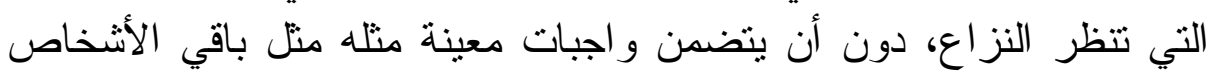

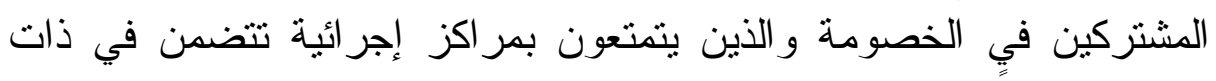
التوقيت حقوقاً وو اجبات إجر ائية.

فلم يتم النص على تخويل الطفل المميز حق الاستماع إليه في

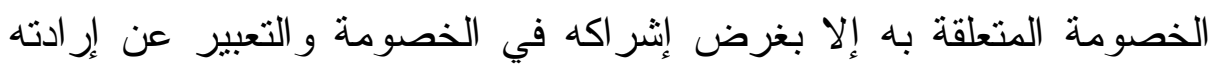

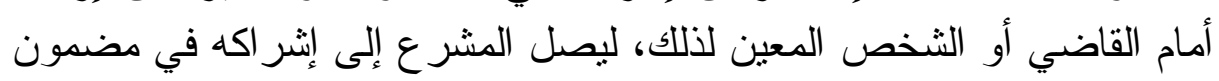

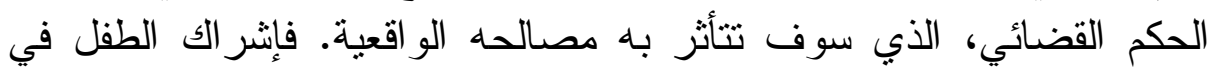

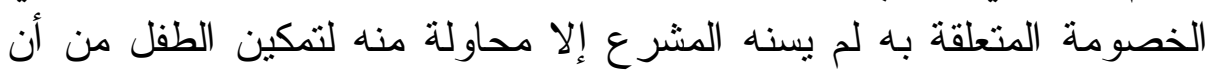

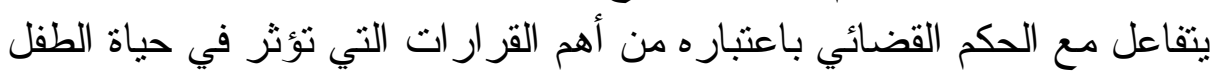

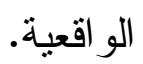

إذن الطفل المستمع إليه يتمتع بمركز إجرائي خاص في الخصومة المدنية المتعلقة به لا يمكن إخضاعه لأي مركز قانوني أخر تقليدي في لئي 
الخصومة المدنية. يتمنل هذا المركز بصفة أساسية في حقه أن يتم الاستماع إذاع إنها

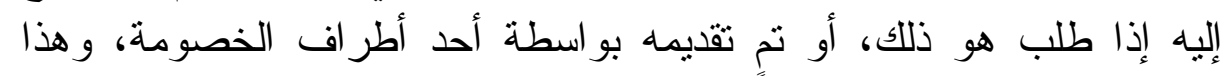

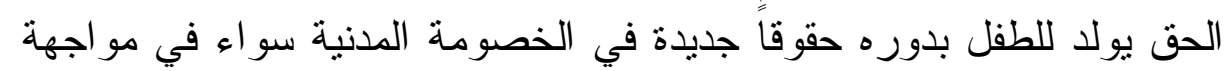

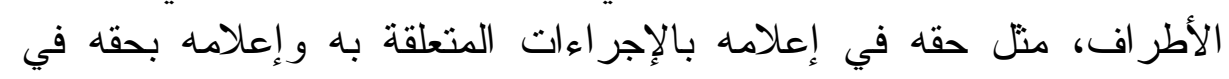

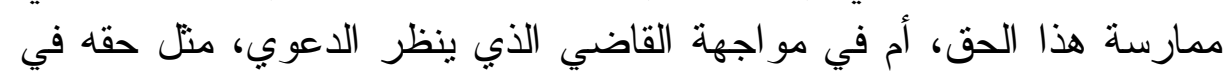

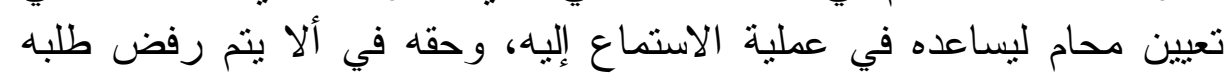

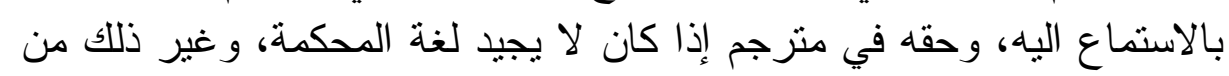
الحقوق.

ونري أنه لا يؤثر في هذه الطبيعة الأثر غير المباشر لممارسة الطفل

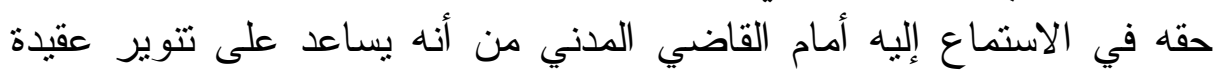

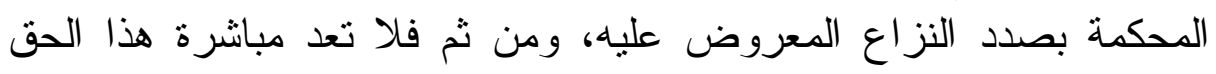

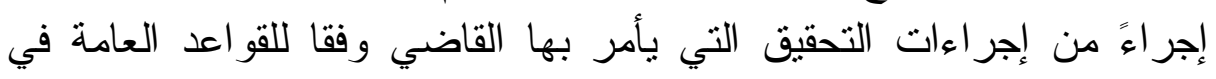
مواد الإثبات. كذلك لا تعد مباشرة الطفل لهذا الحق بمثابة حق من حقوق

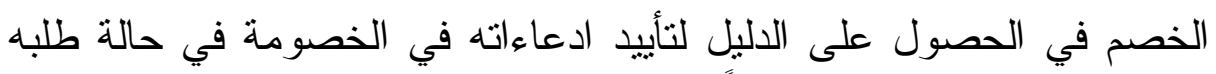

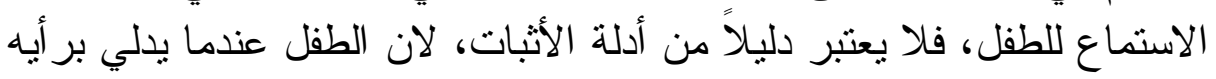

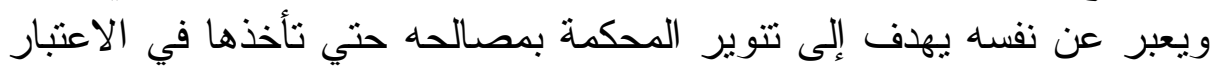

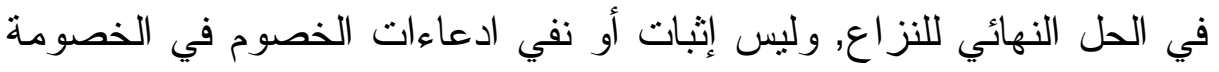
القضائية.

وتزتيبا على ذلك فإنه يجب عند مواجهة أي صعوبة إجرائية تتعلق

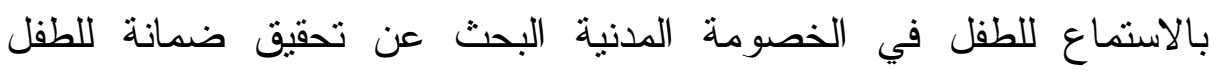
للاستفادة من حقه في الاشتر الك في الإجراءات التي تتعلق بهاه، وليس بحثنها

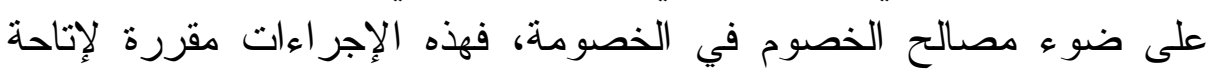

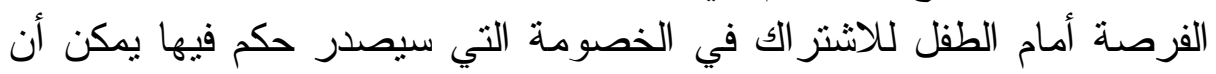

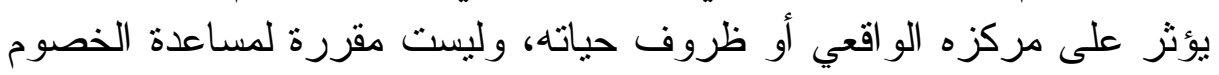
في تأييد ادعاءاتهم في الخصومة أو تمكينهم من حقهم في الإثبات. 


\section{(المبحث الثالث}

\section{نحو تنظيم إجرائي لممارسة الطقل حقه في الاستماع إليه}

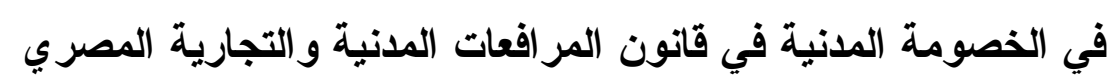

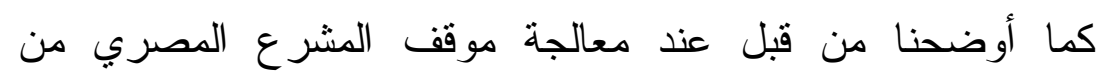

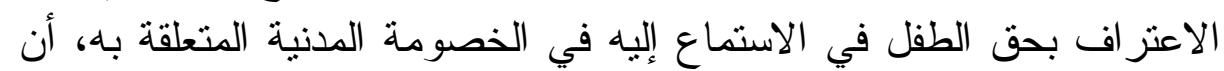

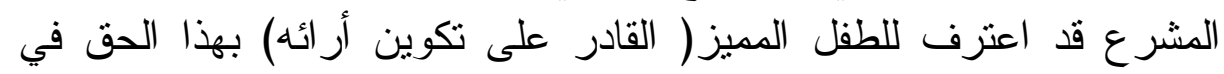

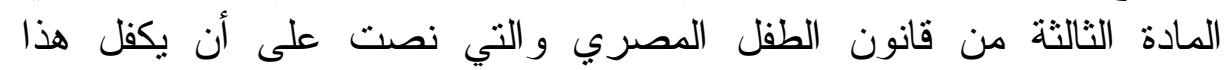

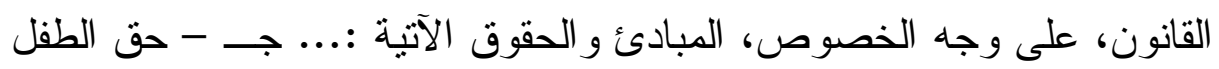

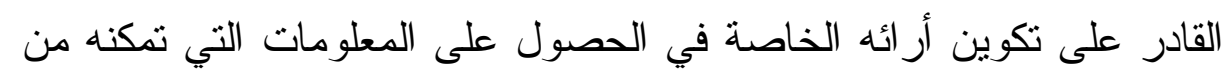

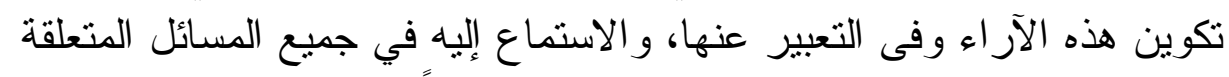

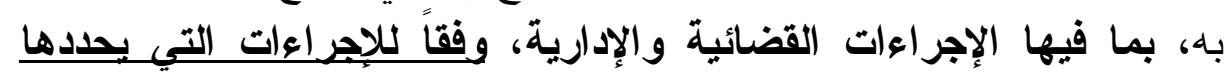
القانون. به،

ولم يقم المشرع المصري - إلي الآن- بتتظيم إجراءات الاستماع

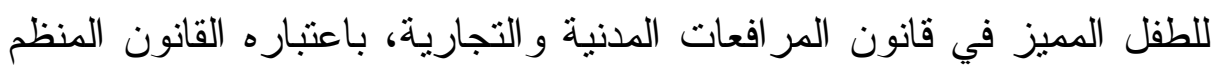

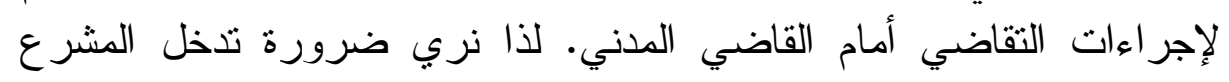

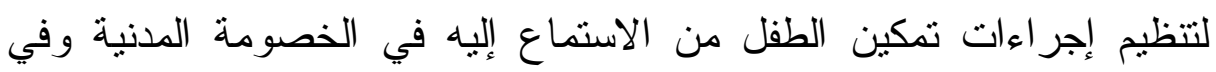

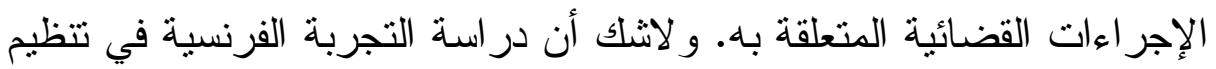

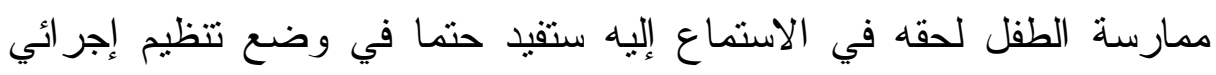

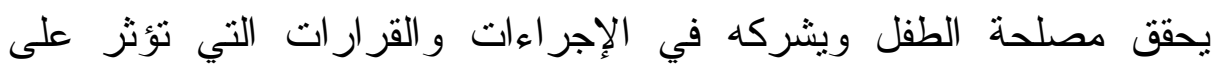

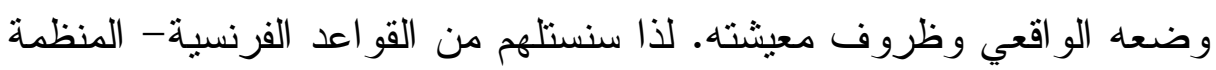

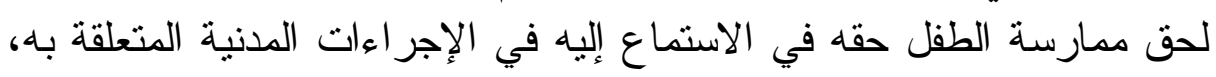

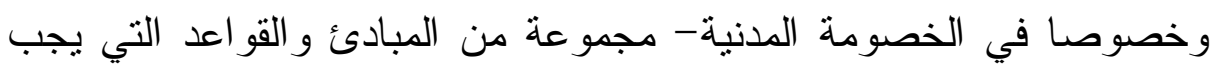
على المشرع بحثها سو اء بتبنيها أم بسن فو اعد أخرى إذها كانت غير ملائمة.

فنري ضرورة النص في قانون المر افعات على مبدأ حق الطفل المميز

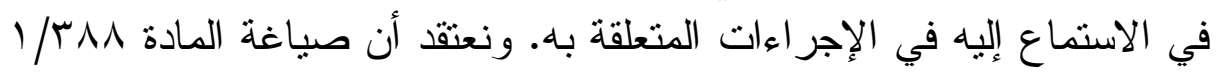

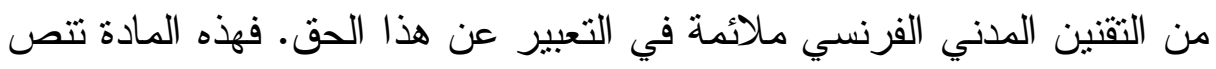

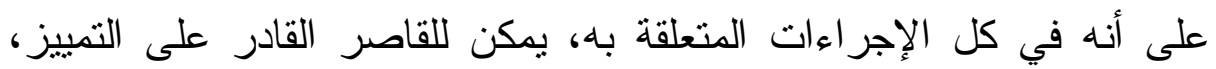
بدون المساس بالقو اعد المتعلقة بتذخله أو برضائه (الحصول على على مو افقته)،

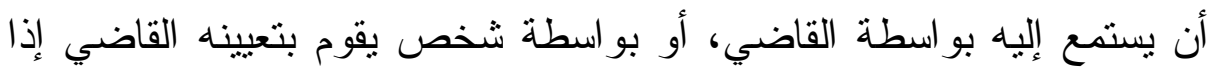


تطلبت مصلحته ذلك. ويكون الاستماع للطفل بقوة القانون إذا طلب ذلك .

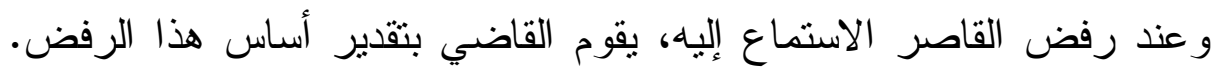

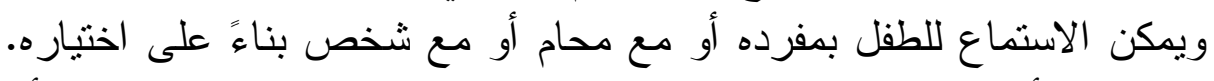

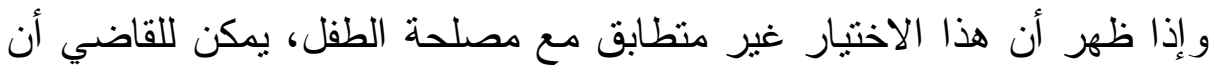

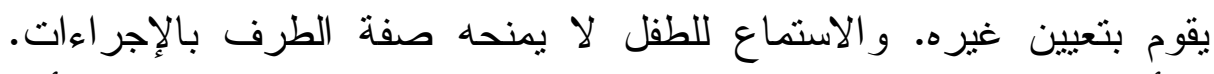

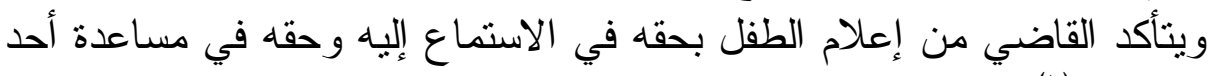

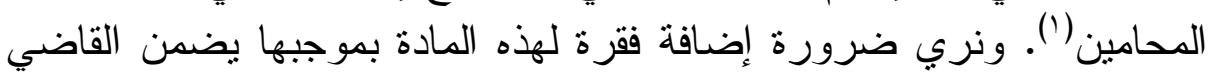

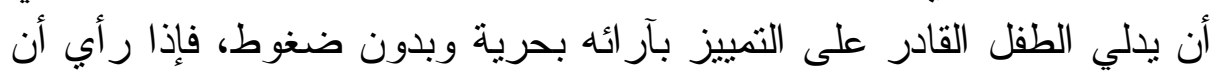

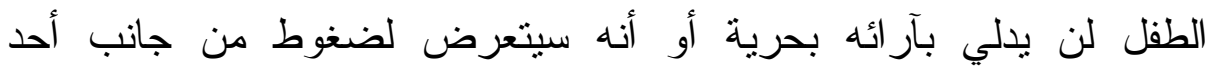

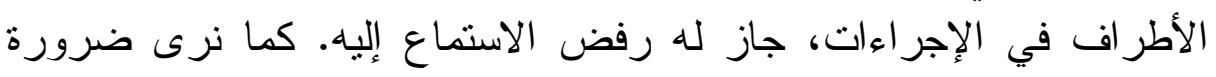

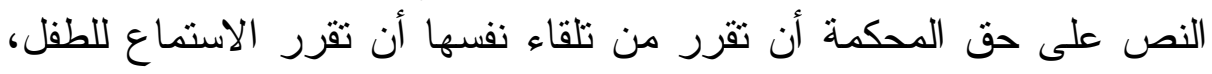

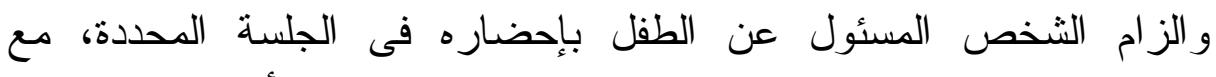

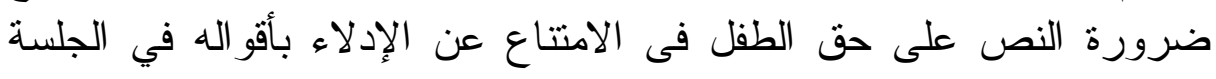
المحددة للاستماع إليه، ما لم يتعزر على الثى الثخص المّلى المسئول عن الطفل القيام بإحضار ه.

كذلك نري تبني نص المادة رسب من تقنين الإجراءات المدنية الفرنسي على الوجه التالي:- فأمَّا ما يتعلق بالفقرة الأولى من هذه دهن المادة،

( $\left.{ }^{1}\right)$ Dans toute procédure le concernant, le mineur capable de discernement peut, sans préjudice des dispositions prévoyant son intervention ou son consentement, être entendu par le juge ou, lorsque son intérêt le commande, par la personne désignée par le juge à cet effet.Cette audition est de droit lorsque le mineur en fait la demande. Lorsque le mineur refuse d'être entendu, le juge apprécie le bien-fondé de ce refus. Il peut être entendu seul, avec un avocat ou une personne de son choix. Si ce choix n'apparait pas conforme à l'intérêt du mineur, le juge peut procéder à la désignation d'une autre personne.L'audition du mineur ne lui confère pas la qualité de partie à la procédure.Le juge s'assure que le mineur a été informé de son droit à être entendu et à être assisté par un avocat. 
فإنه يمكن تنبيها على الوجه التالي (')

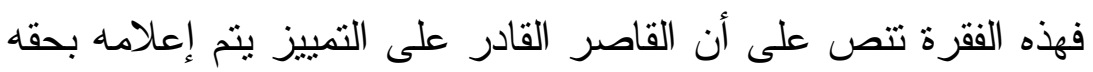

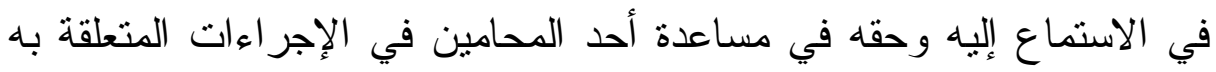

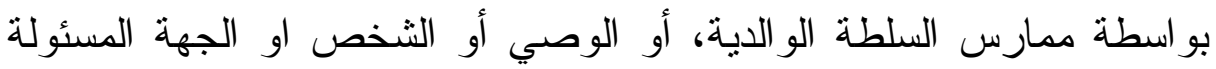

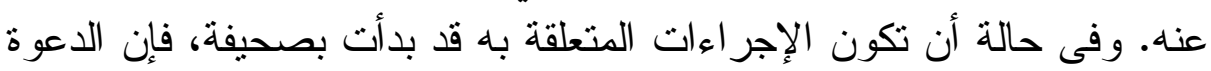

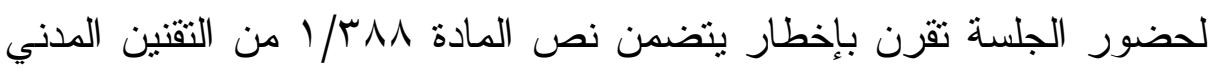

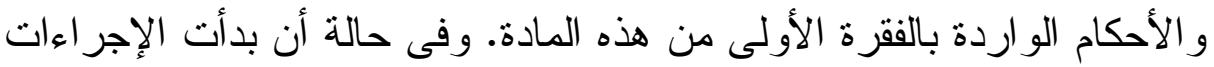
بطريق التكليف بالحضور فإن الإخطار المشار إليه في الفقرة السابقة يقترن

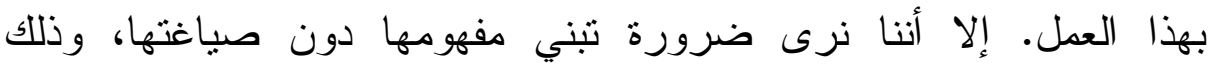

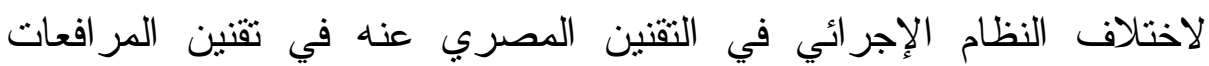

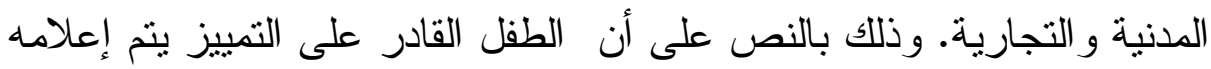

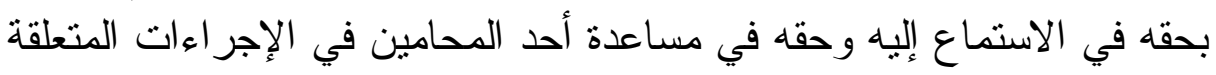

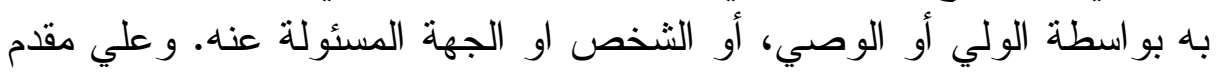

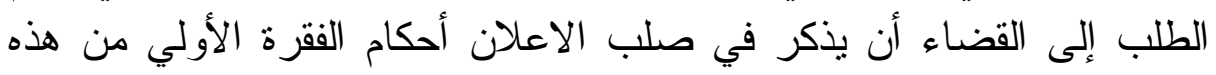

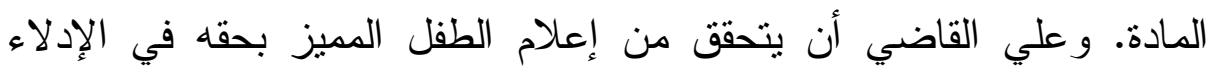
بأقو اله في الإجراءات المتعلقة به و الحق في الاستعانة بمحام ليساعده أثناء جلسة الاستماع إليه.

كذلك نري تنني ما تتص عليه الفقرة الثانية من المادة مبس من تقنين

(1) Le mineur capable de discernement est informé par le ou les titulaires de l'exercice de l'autorité parentale, le tuteur ou, le cas échéant, par la personne ou le service à qui il a été confié de son droit à être entendu et à être assisté d'un avocat dans toutes les procédures le concernant. Lorsque la procédure est introduite par requête, la convocation à l'audience est accompagnée d'un avis rappelant les dispositions de l'article 388-1 du code civil et celles du premier alinéa du présent article. Lorsque la procédure est introduite par acte d'huissier, l'avis mentionné à l'alinéa précédent est joint à celui-ci. 
الإجر اءات المدنية(')وهذه الفقرة نتص على أن طلب الاستماع يقدم بدون

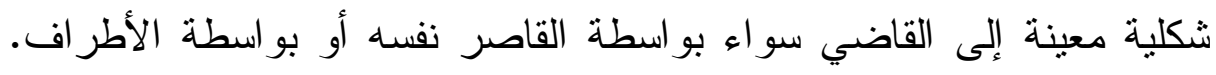

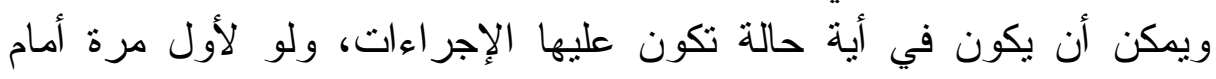

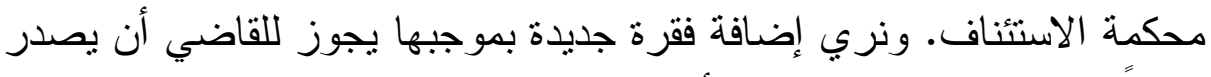

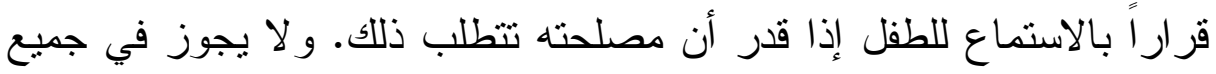

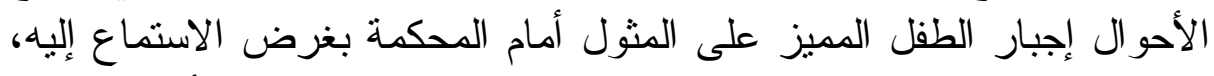

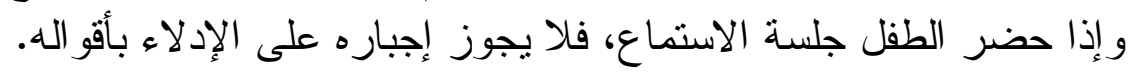

ونري كذلك تبني ما تتص عليه الفقرة الثالثة من المادة ^rا من تقنين

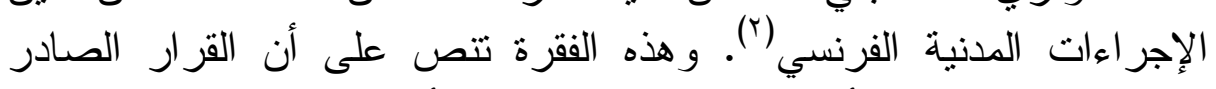
بالاستماع للطفل يمكن أن بؤشر به بملف الدعوي أو تسجيله بمحضر الجلسة.

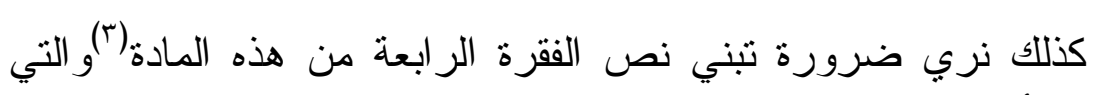

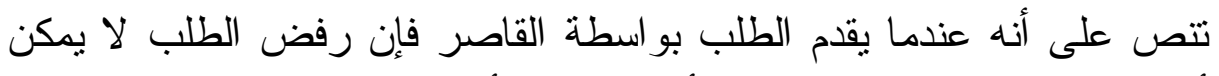

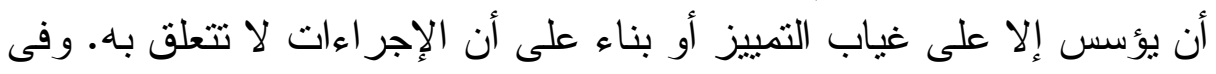

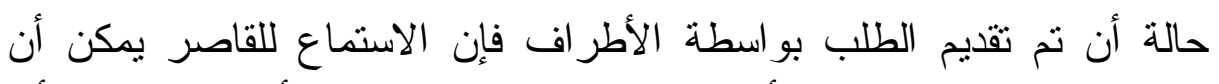

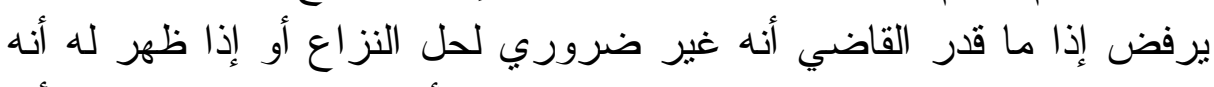

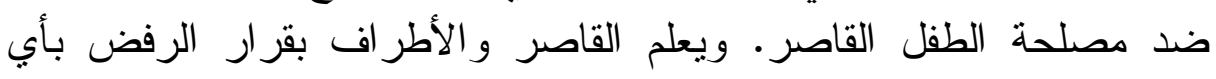

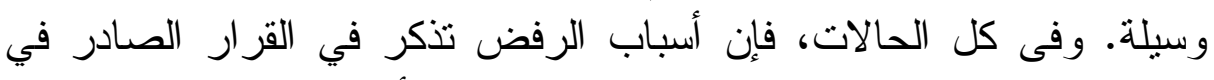

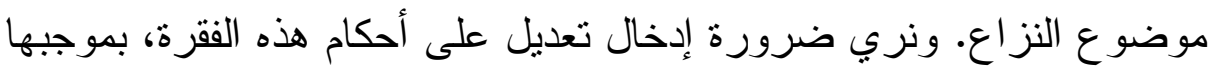

$\left({ }^{1}\right)$ La demande d'audition est présentée sans forme au juge par le mineur lui-même ou par les parties. Elle peut l'être en tout état de la procédure et même pour la première fois en cause d'appel

$\left({ }^{2}\right)$ La décision ordonnant l'audition peut revêtir la forme d'une simple mention au dossier ou au registre d'audience.

$\left({ }^{3}\right)$ Lorsque la demande est formée par le mineur, le refus d'audition ne peut être fondé que sur son absence de discernement ou sur le fait que la procédure ne le concerne pas. Lorsque la demande est formée par les parties, l'audition peut également être refusée si le juge ne l'estime pas nécessaire à la solution du litige ou si elle lui paraît contraire à l'intérêt de l'enfant mineur. Le mineur et les parties sont avisés du refus par tout moyen. Dans tous les cas, les motifs du refus sont mentionnés dans la décision au fond. 
يمكن للقاضي أن يرفض طلب القاصر المميز الاستماع إليه، إذا رأي،

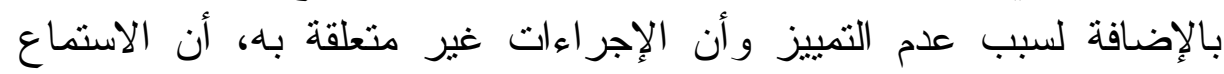

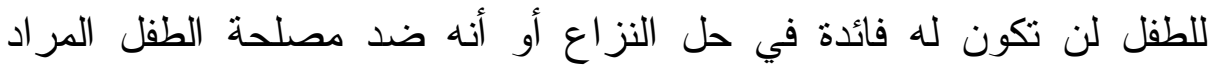

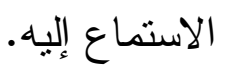

كذلك نري عدم تنبى أحكام الفقرة الخامسة من هذه المادة(')، و التي

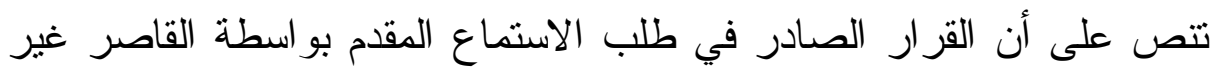

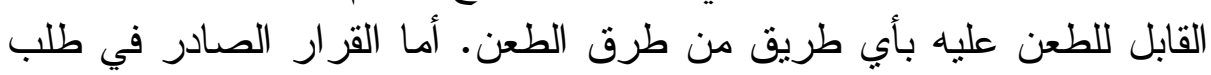

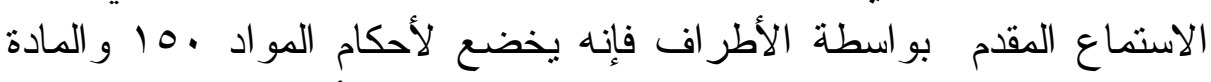
ror

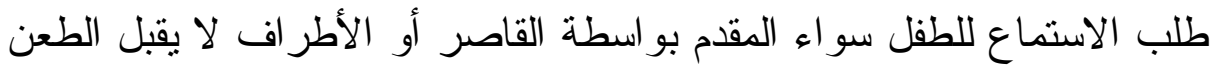

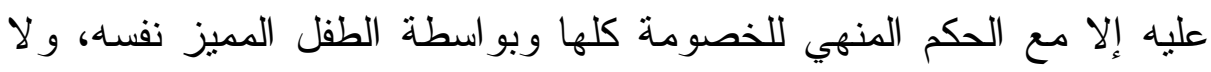
يحق للأطر اف الطعن على هذا القرار. إذ أن هذه الإجر اءات مقررة لتمكينه

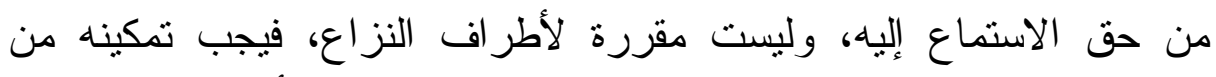

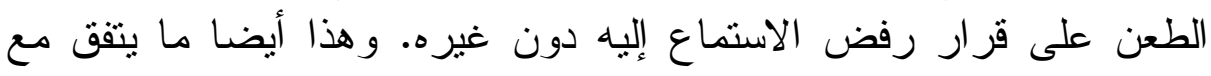

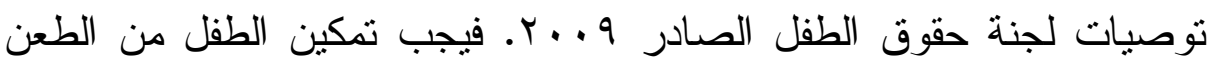

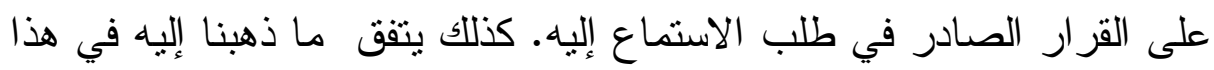

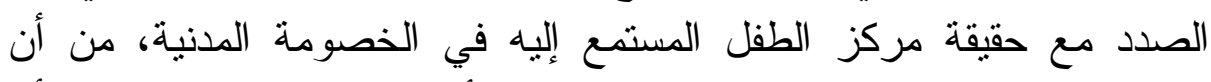

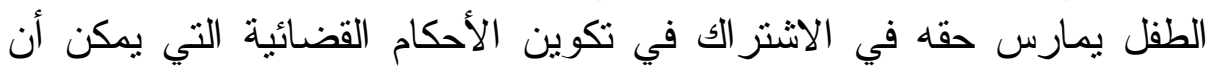

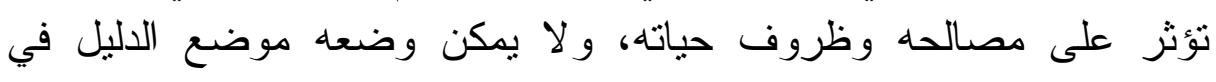
الخصومة المدنية.

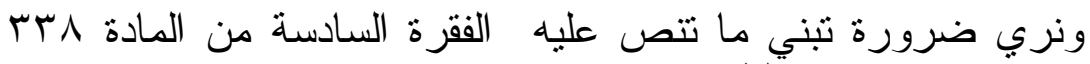

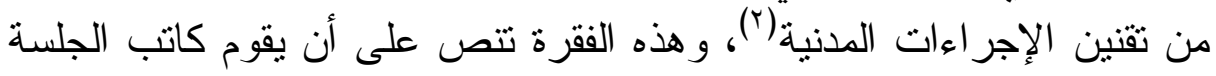

(1) La décision statuant sur la demande d'audition formée par le mineur n'est susceptible d'aucun recours. La décision statuant sur la demande d'audition formée par les parties est soumise aux dispositions des articles 150 et 152.

$\left({ }^{2}\right)$ Le greffe ou, le cas échéant, la personne désignée par le juge pour entendre le mineur adresse à celui-ci, par lettre simple, une convocation en vue de son audition. La convocation l'informe de son droit à être entendu seul, avec un avocat ou une personne de 
أو الثخص المعين من القاضي للاستماع للطفل بدعوة الطفل عن طريق

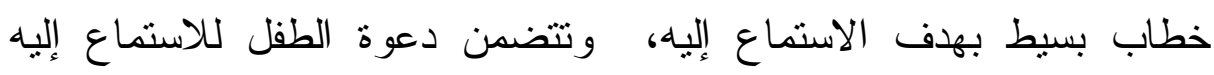

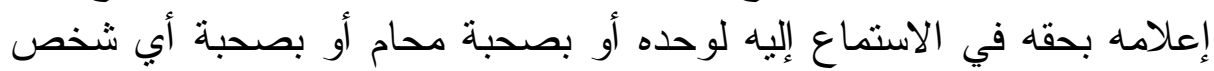

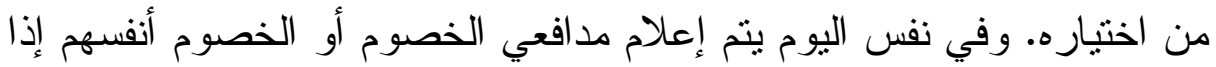

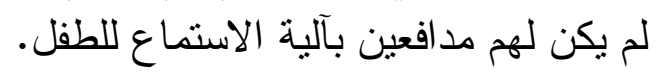

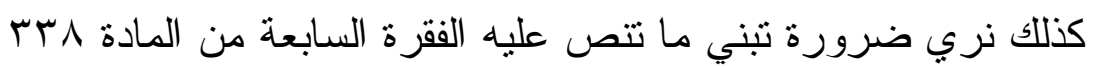

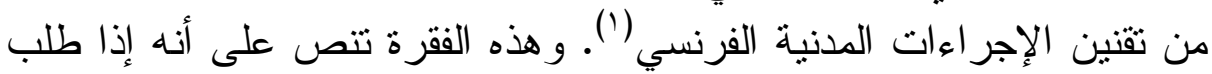

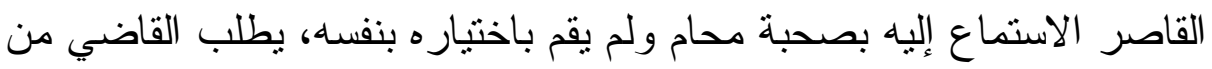
نقيب المحامين المختص تعيين محام بأي وسيلة كانت.

وكذللك نري ضرورة تبني ما تتص عليه الفقرة الثامنة من هذه فأنه

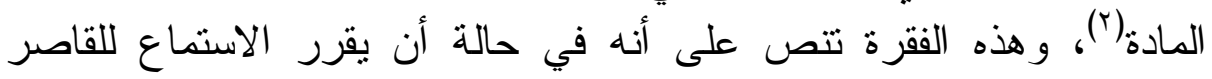

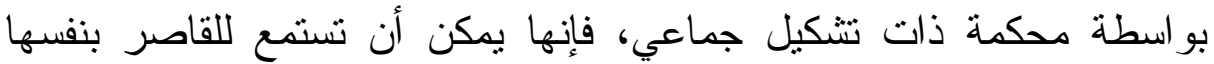

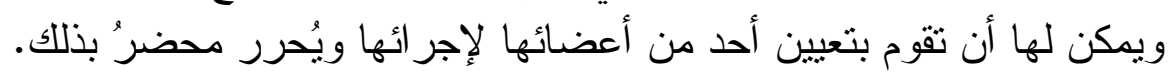
كذلك نري ضرورة تنبي ما تتص عليه الفقرة التاسعة من هذه المادة،

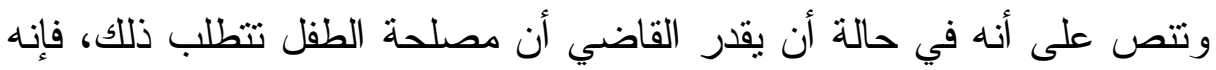

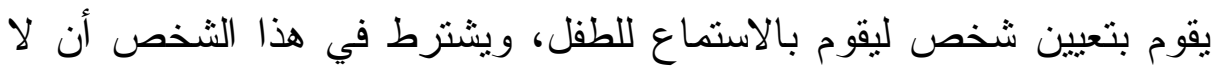

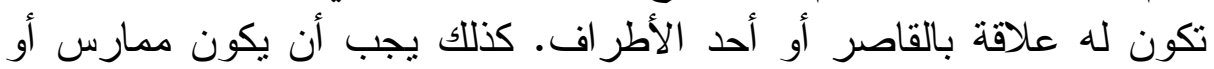

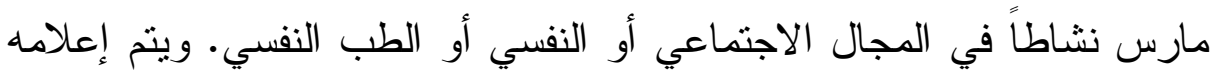
بمهيته بدون مدة معينة وبأي وسيلة بو اسطة كاتب الب المحكمة.

كذلك تنبي ما تتص عليه الفقرة العاشرة من هذه المادة، وهي تتص

son choix. Le même jour, les défenseurs des parties et, à défaut, les parties elles-mêmes sont avisés des modalités de l'audition

$\left.{ }^{1}\right)$ Si le mineur demande à être entendu avec un avocat et s'il ne choisit pas lui-même celui-ci, le juge requiert, par tout moyen, la désignation d'un avocat par le bâtonnier.

$\left({ }^{2}\right)$ Lorsque l'audition est ordonnée par une formation collégiale, celle-ci peut entendre elle-même le mineur ou désigner l'un de ses membres pour procéder à l'audition et lui en rendre compte 
على أنه إذا قابل الثخص المسئول عن الاستماع للقاصر صعوبات معينة، فإنه يلجأ للقاضي مباشرة.

كذللك نري ضرورة تبني ما تتص عليه الفقرة الحادية عشر من هذه آنا

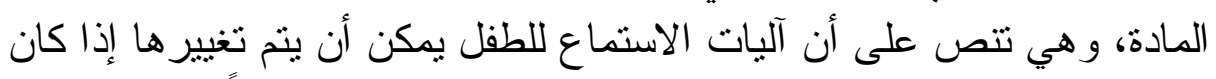

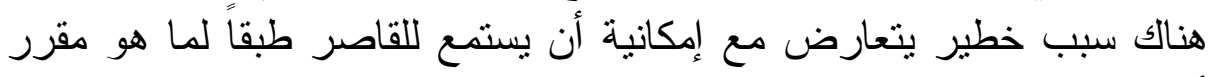
أصلا.

كذللك نري ضرورة تبني ما تتص عليه الفقرة الثانية عشرة من ذات

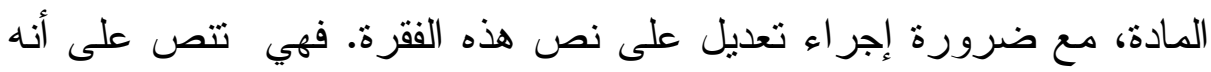

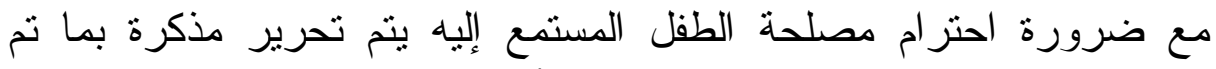

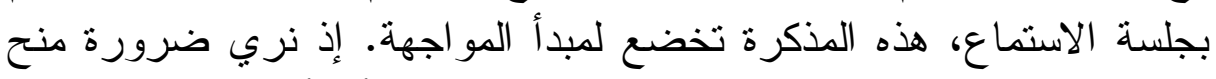

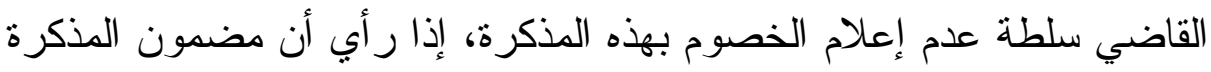

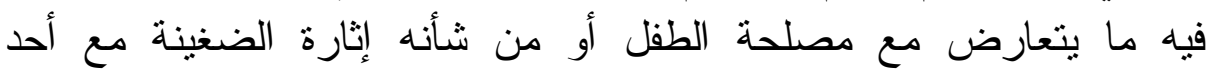

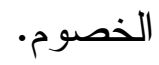




\section{خاتمــــة}

منذ دخول الاتفاقية الدولية لحماية حقوق الطفل حيز النفاذ، وشهدت

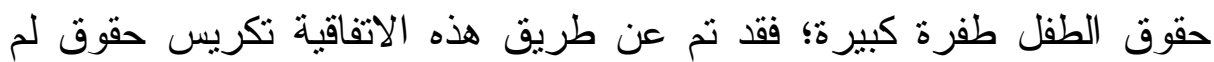

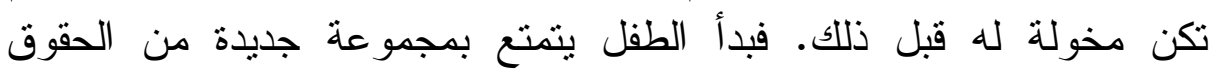

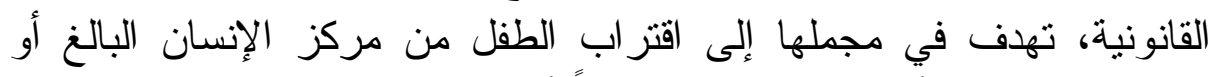

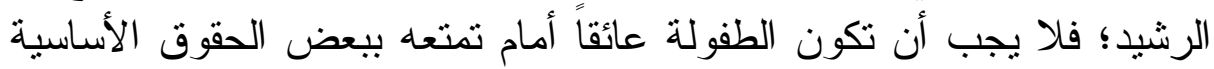

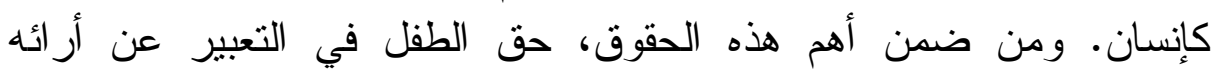

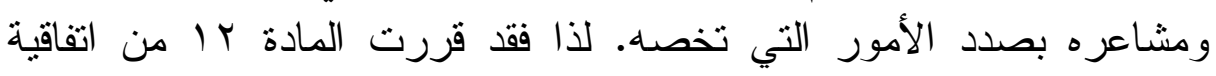

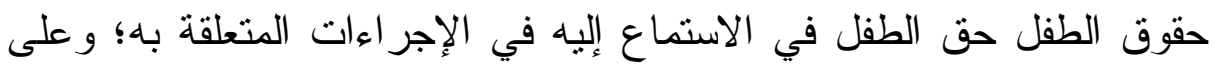
إثر ذلك قامت التشريعات الوطنية بتكريس هذا الحق في تشريعاتها الوطنية.

وكان للمشرع الفرنسي تجربة ثرية في تمكين الطفل من التمتع بهذا

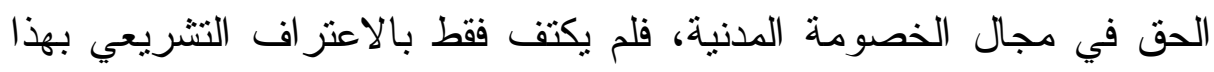

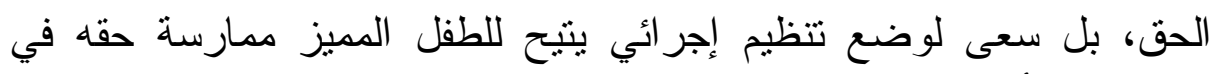
التعبير عن أر ائه في الخصومة لئ المدنية.

في المقابل، فقد اعترف المشرع المصري في المادة الثالثة فقرة ج الإنه

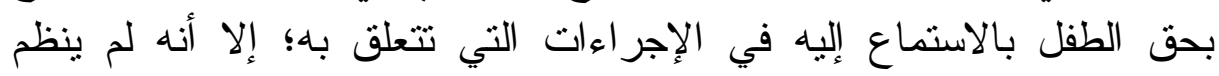

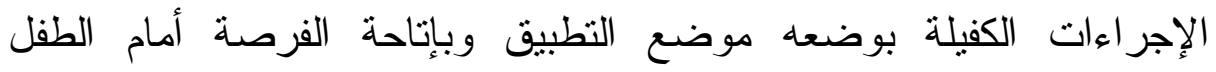

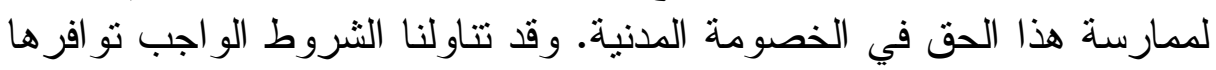

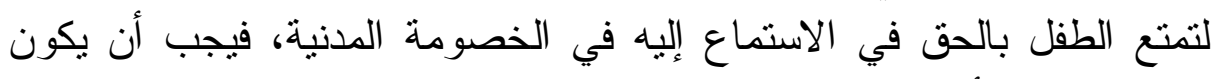
مميز ا، ويجب أن تكون الإجر اءات متعلقة به، حتى بمكن له الاعن الاستفادة من هذا لهن

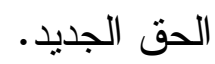

وقد جاء المشرع الفرنسي بتتظيم إجر ائي تتاح من خلاله الفرصة أمام الطفل في التمتع بحقه في الاستماع إليه في الخصومة الفيه المدنية المتعلقة به.

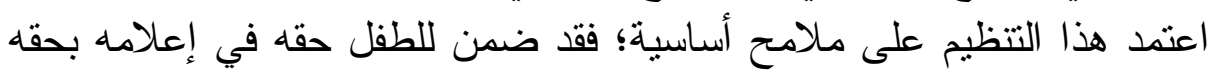

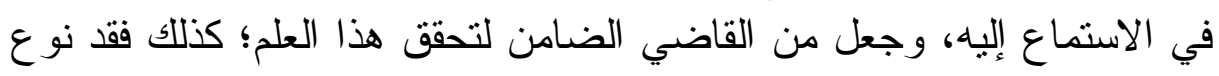

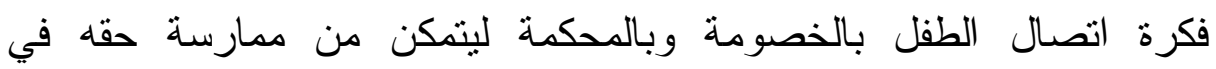

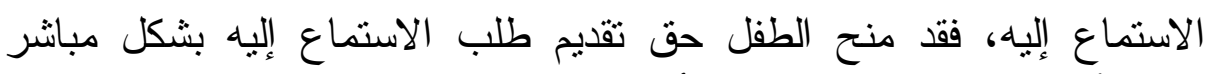

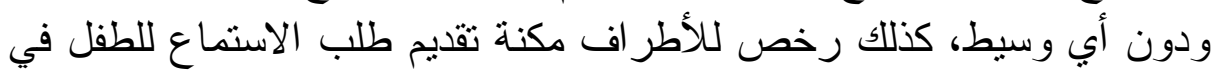

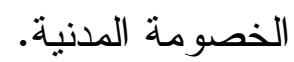


وفى فرضية تقديم طلب الاستماع بواسطة الطفل نفسه فقد قرر

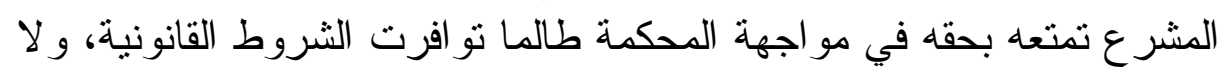

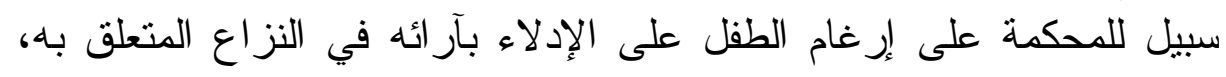

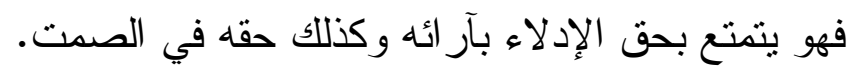

كذللك فقد نظم المشرع الفرنسي آليات الاستماع للطفل سو اء بواسطة

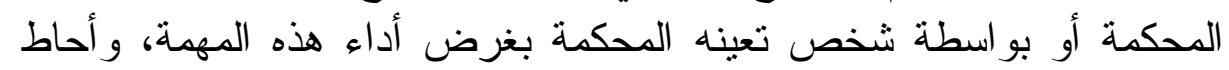

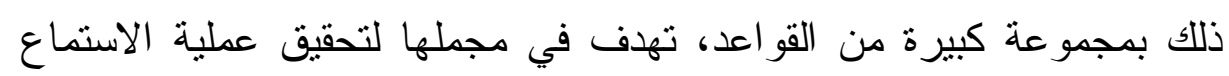

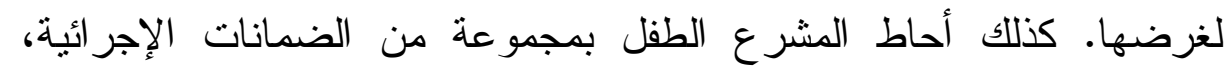

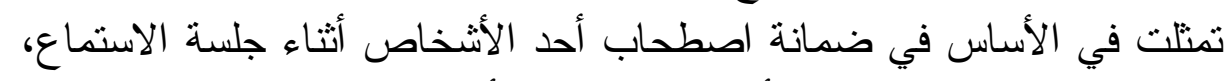
وفى ضرورة تحرير مذكرة بأقو ال الطفل على أن ير اعى فيها مصالح الطفل.

ولقد تعرضنا لتحديد المركز الإجرائي للطفل المستمع إليه، وتوصلنا

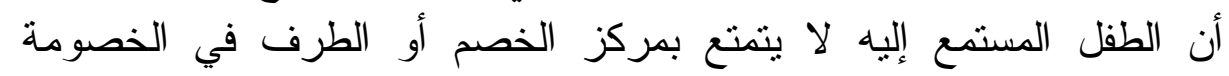

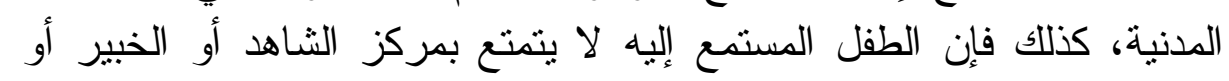

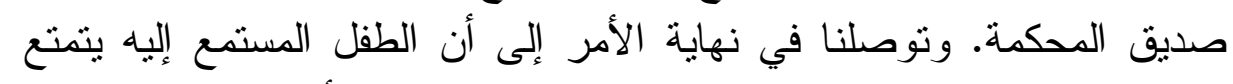

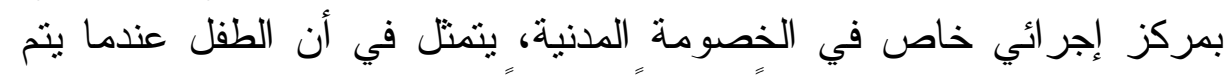
الاستماع إليه، فإنه يمارس حقاً إجر ائياً نشاركياً.

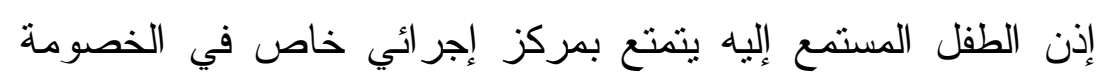

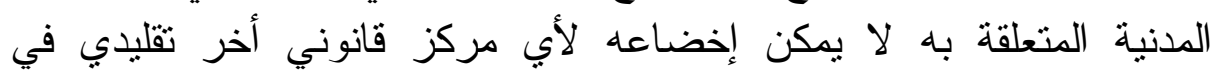

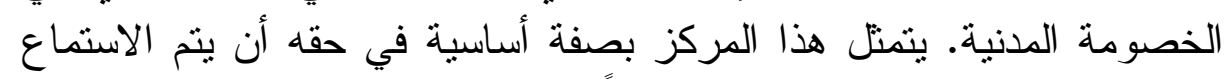

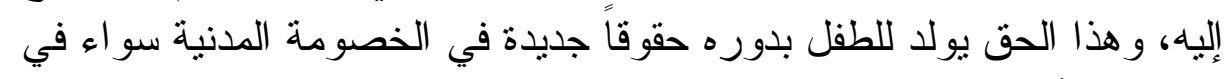

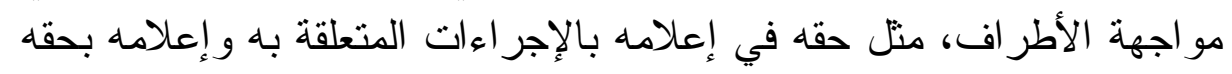

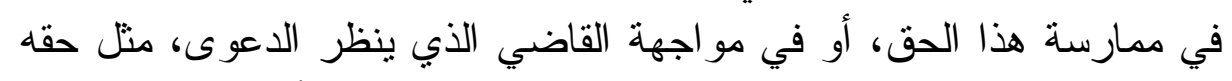

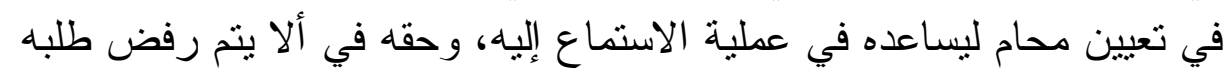

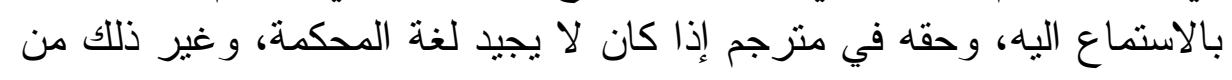
الحقوق.

ونري أنه لا يؤثر في هذه الطبيعة الأثر غير المباشر لممارسة الطفل

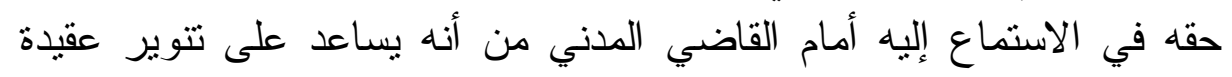

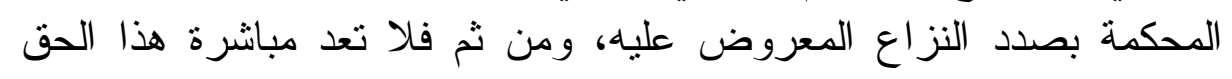


إجر اءاً من إجر اءات التحقيق التي يأمر بها القاضي وفقا للقو اعد العامة في

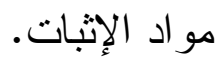

كذلك لا تعد مباشرة الطفل لهذا الحق بمثابة حق من حقوق الخصم في

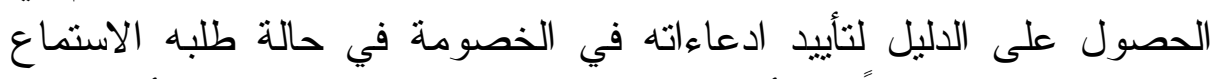

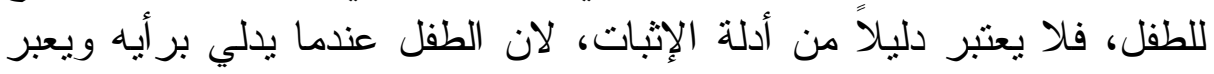

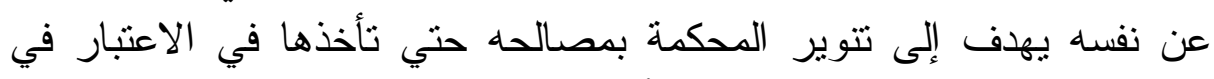
الحل النهائي للنزاع, وليس إثبات أو نفي ادعاءات الخهات الخصوم في الخصومة

القضائية.

وترنيا على ذلك فإنه يجب عند مواجهة أي صعوبة إجرائية تتعلق

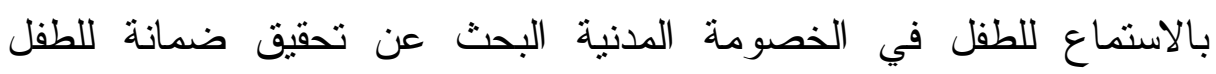
للاستفادة من حقه في الاشتر الك في الإجراءات التي تلتعلق بها، وليس بحثثها

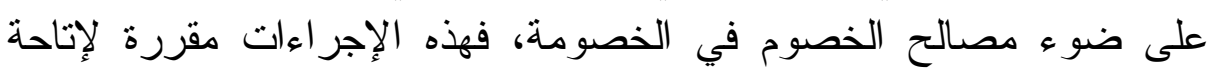

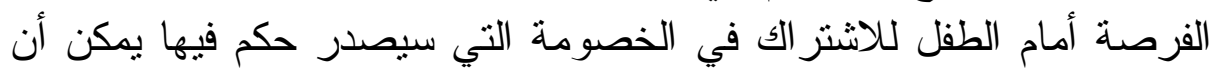

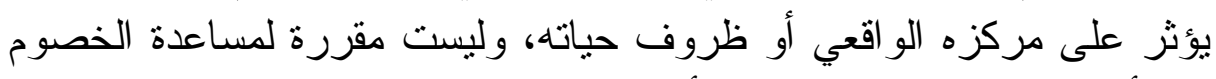
في تأييد ادعاءاتهم في الخصومة أو تمكينهم من حقهم في الإثبات.

وقد حاولنا على ضوء التجربة القانونية الفرنسية وضع تتظيم إجرائي يوفر

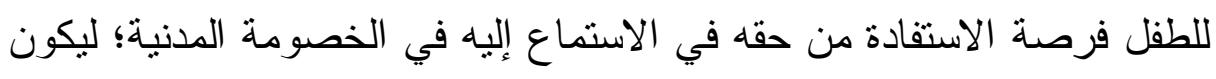

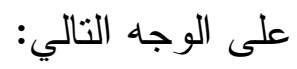

أولا: نري ضرورة النص في قانون المر افعات على مبدأ حق الطفل المميز

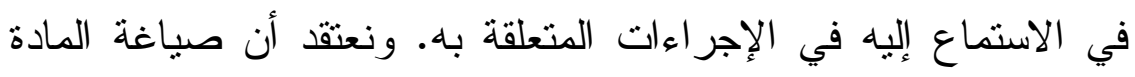

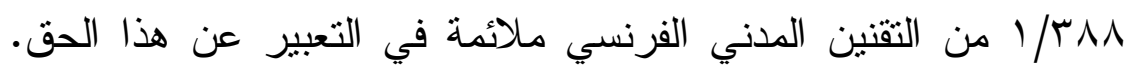

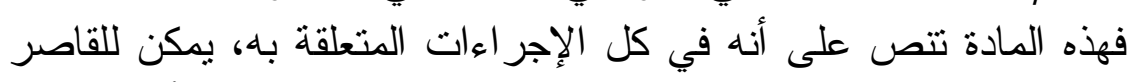

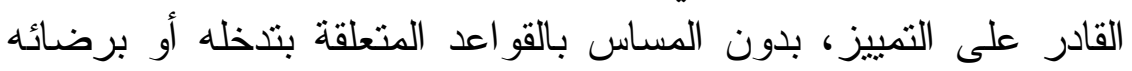

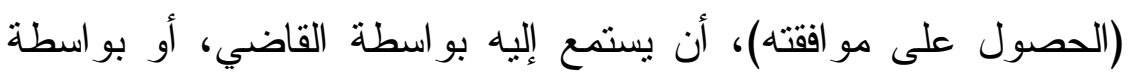

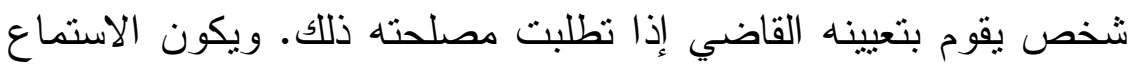
للطفل بقوة القانون إذا طلب ذللك . و عند رفض القاصر الاستماع إلى إليه، يقوم القاضي بتقدير أساس هذا الرفض. ويمكن الاستماع للطفل بمفرده

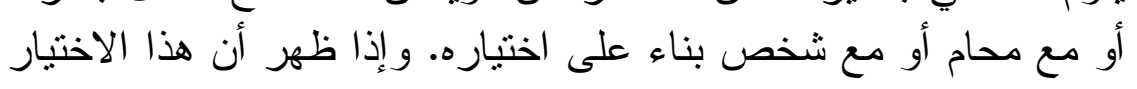


غير متطابق مع مصلحة الطفل، يمكن للقاضي أن يقوم بتعيين غيره.

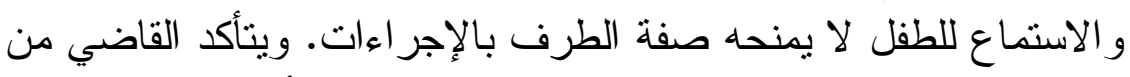
إعلام الطفل بحقه في الاستماع إليه وحقه في مساعدة أحد المحامين.

ثانيا: نري ضرورة إضافة فقرة لهذه المادة بموجبها يضمن القاضي

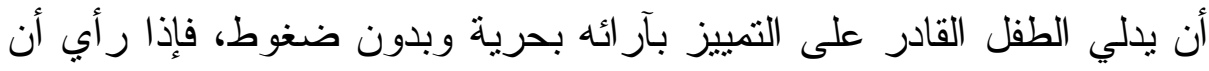

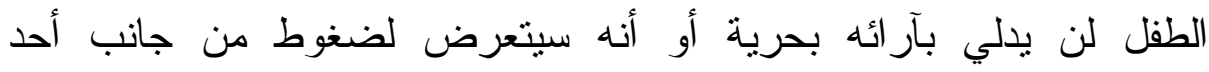

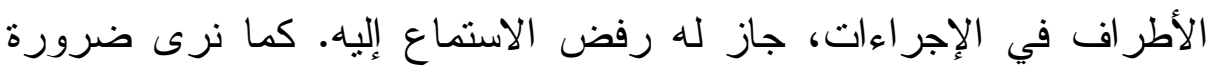

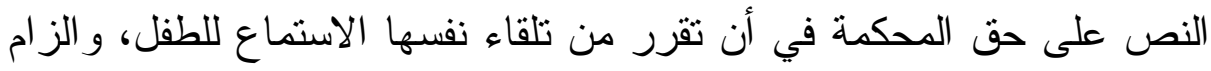

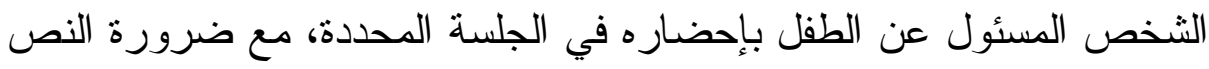

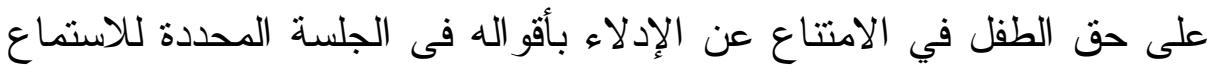
إليه، ما لم يتعزر على الثخص المسئول عن الطفل القيام بإحضاره.

ثالثا: كذلك نري تبني الفقرة الأولى من نص المادة مبس من ثقنين الإجر اءات المدنية الفرنسي على الوجه التالي:

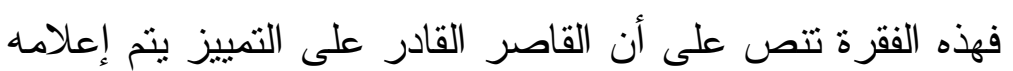

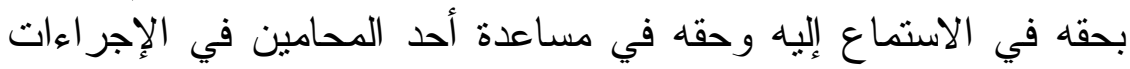

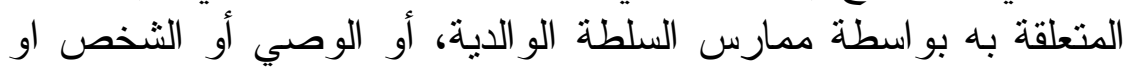

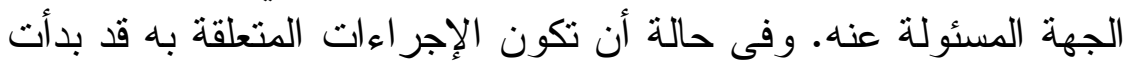

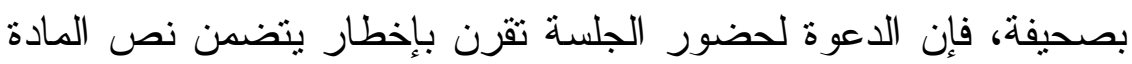

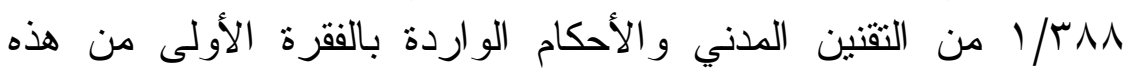

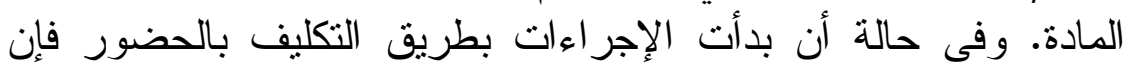

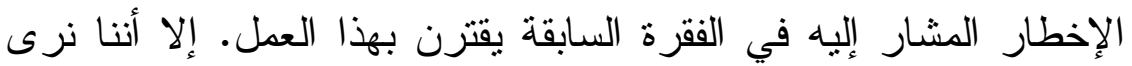
ضرورة تبني مفهومها دون صياغتها، وذللك لاختلاف النظام الإجرائي

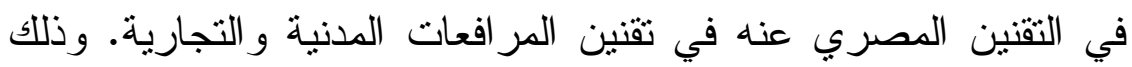

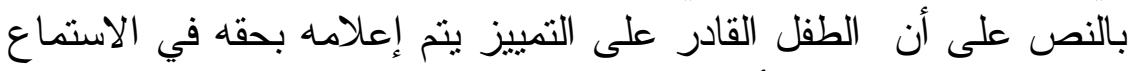

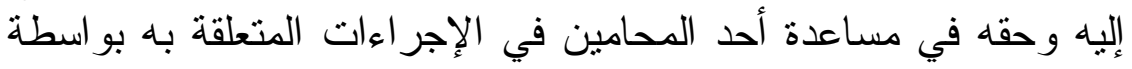

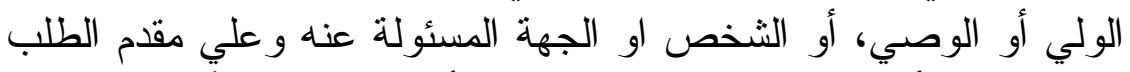

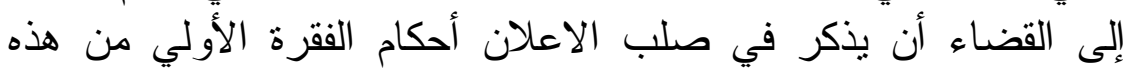

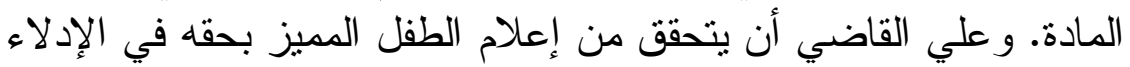
بأقو اله في الإجراءات المتعلقة به و الحق في الإستعانة بمحام ليساعده إلهاه أثناء جلسة الاستماع في الإليه. 
رابعا: كذلك نري تبني الفقرة الأولى من نص المادة ربr من تقنين

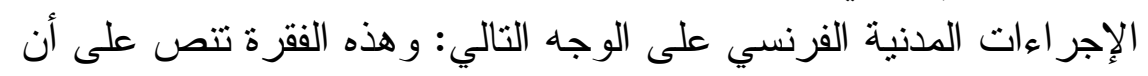

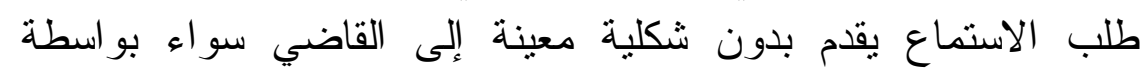

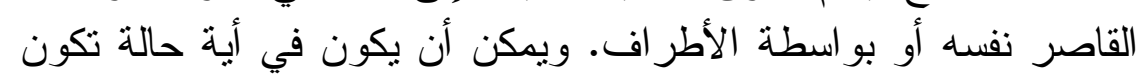

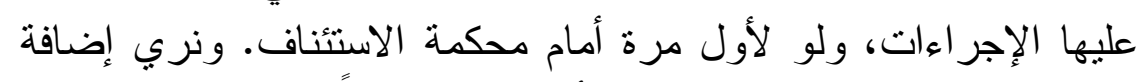

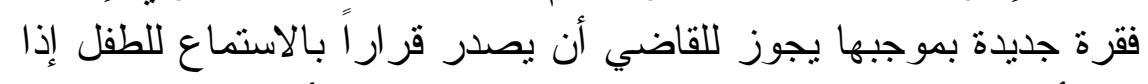

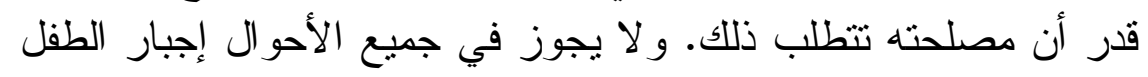

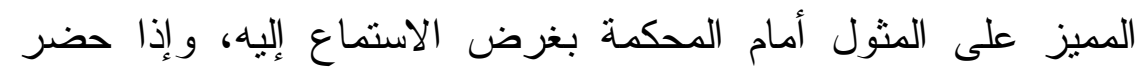

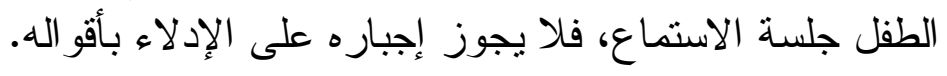

خامسا: نري كذلك تبني ما تتص عليه الفقرة الثالثة من المادة ^شب من تقنين

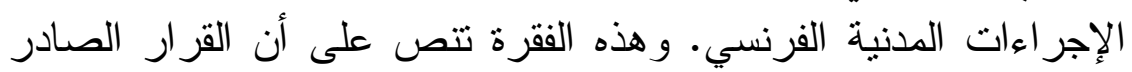

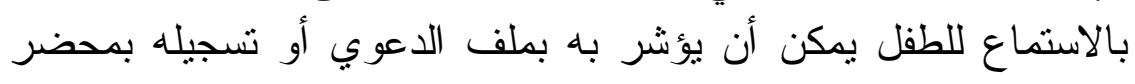
الجلسة.

سادسا: كذلك نري ضرورة تنبي نص الفقرة الر ابعة من هذه المادة، والتي

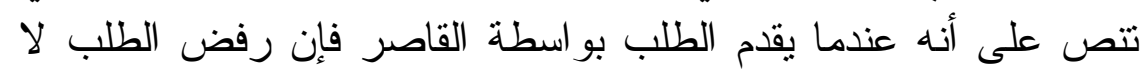

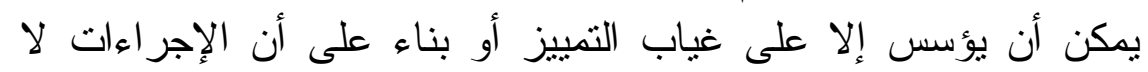

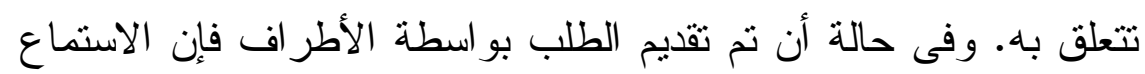

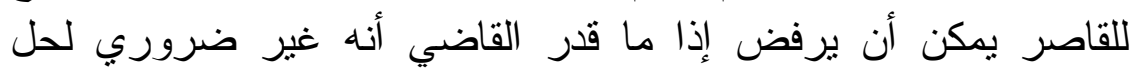

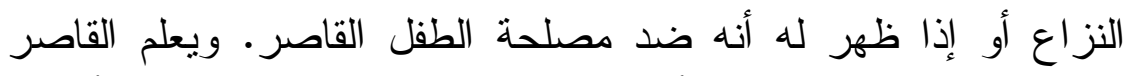

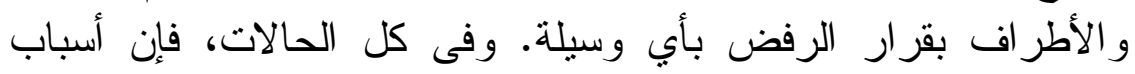

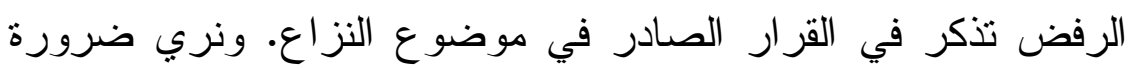

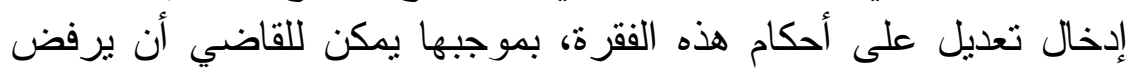

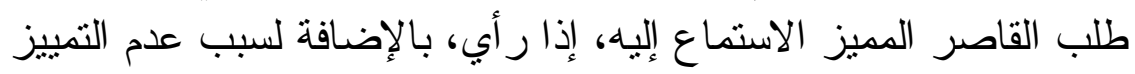

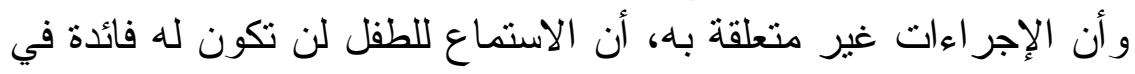
حل النزاع أو أنه ضد مصلحة الطفل المر اد الاستماع إليه.

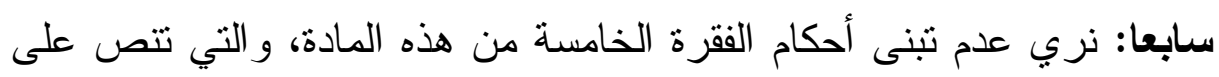

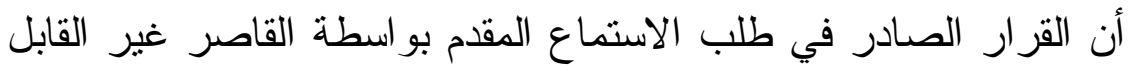

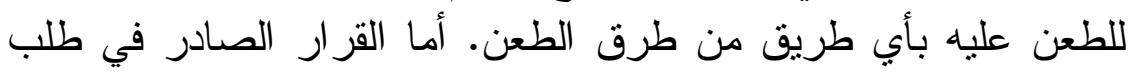

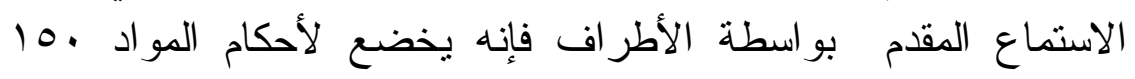


و المادة 10 ـ . بحيث يصبح النص المقترح على الوجه التالي: أن القرار

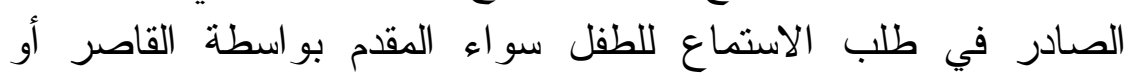

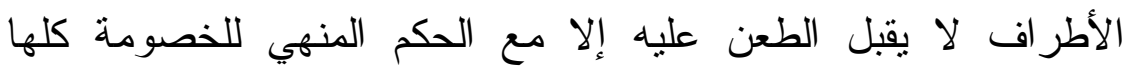

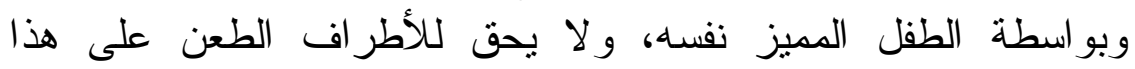
القر ار .

إذ أن هذه الإجراءات مقررة لتمكينه من حق الاستماع إليه،

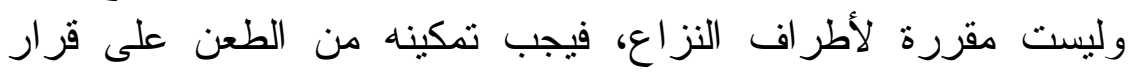

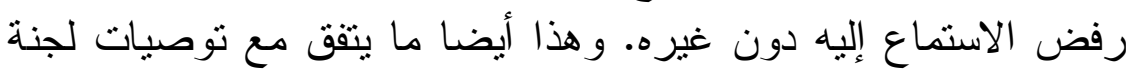

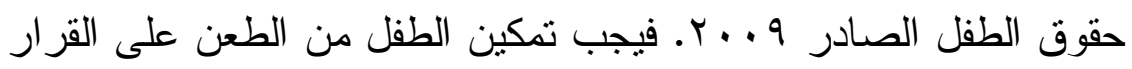

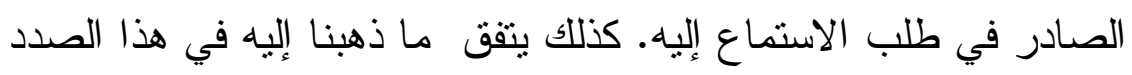

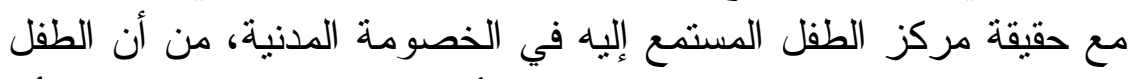

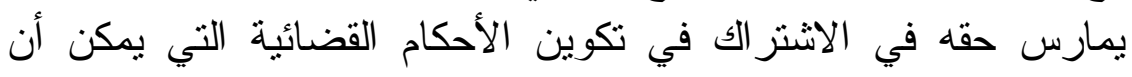

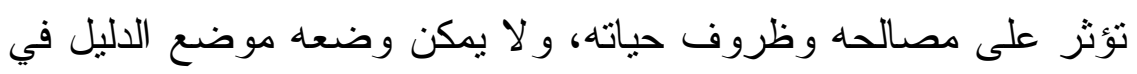
الخصومة المدنية.

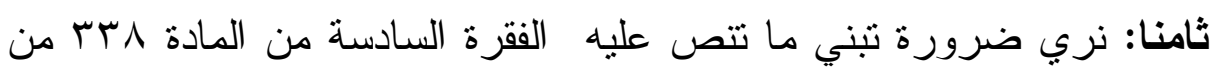

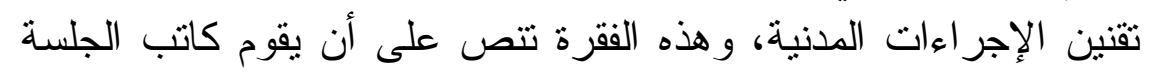

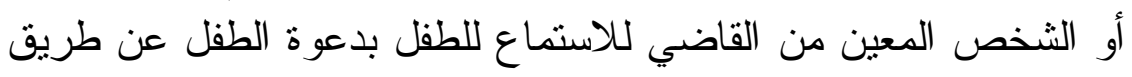

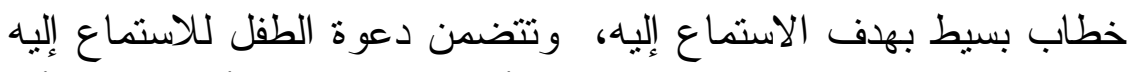

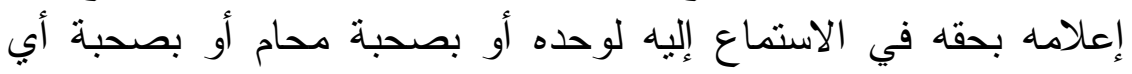

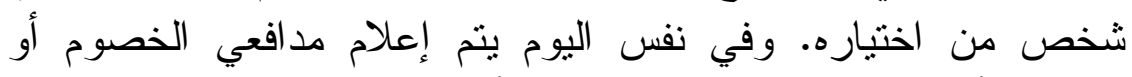

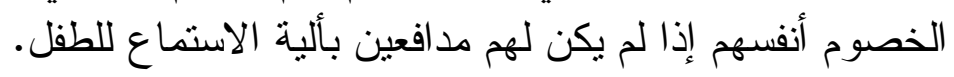

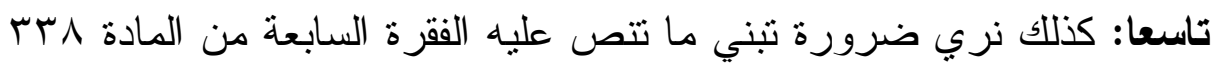

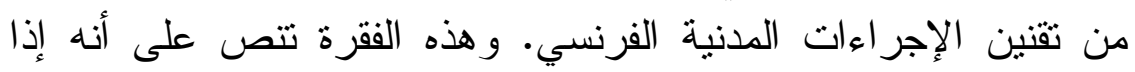

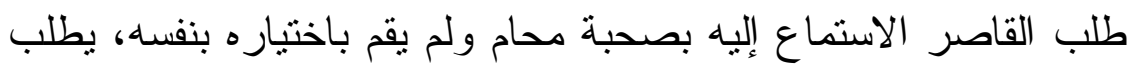

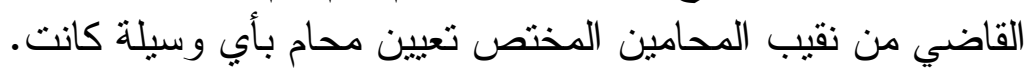

عاثر ا: كذلك نري ضرورة تنبي ما تتص عليه الفقرة الثامنة من هذه المادة،

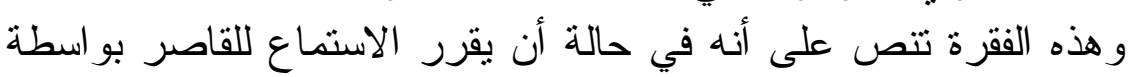

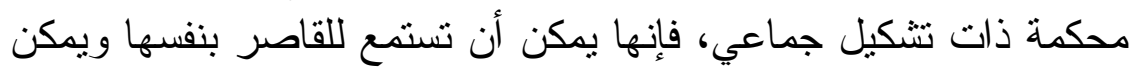

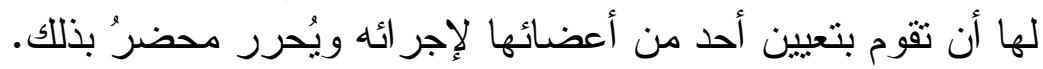


حادي عشر: كذلك نري ضرورة تبني ما تتص عليه الفقرة التاسعة من هذه

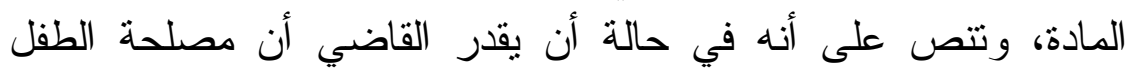

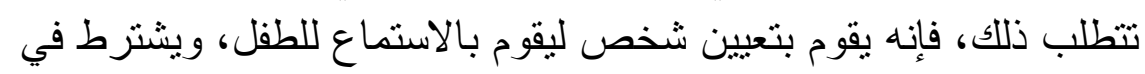

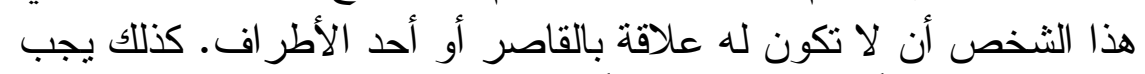

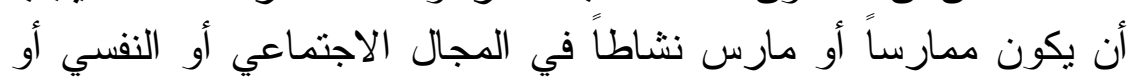

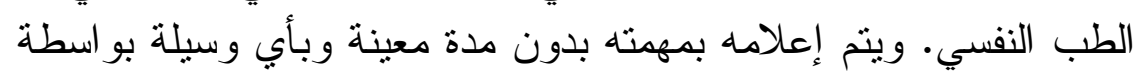

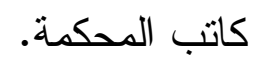

ثاني عشر: كذللك تبني ما تتص عليه الفقرة العاثرة من هذه المادة، وهي

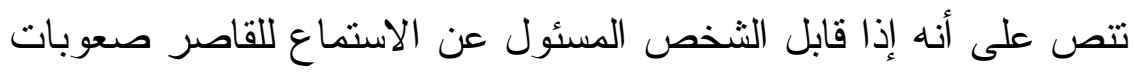
معينة، فإنه يلجأ للقاضي مباشرة.

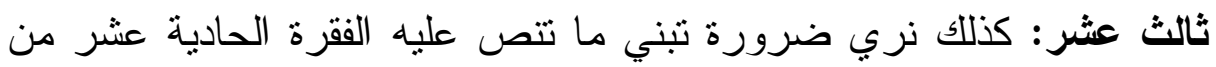
هذه المادة، وهي تتص على أن آليات الاستماع للطفل يمكن أن أن ينم

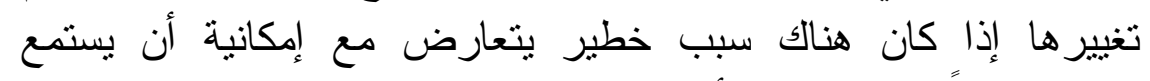
للقاصر طبقاً لما هو مقرر أصلان هناك لغير

رابع عشر: كذلك نري ضرورة تبني ما تتص عليه الفقرة الثانية عشرة من

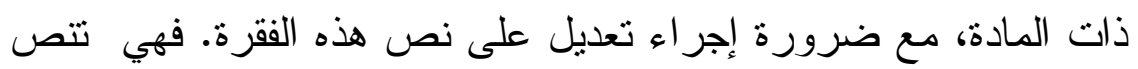

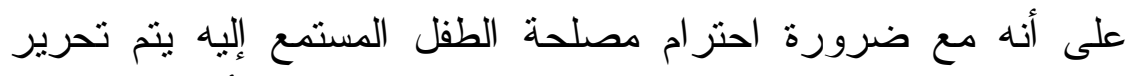

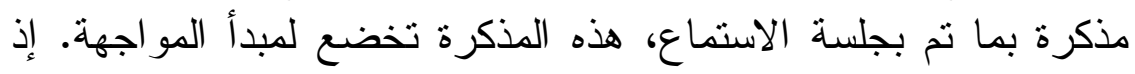

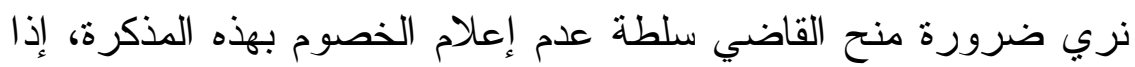

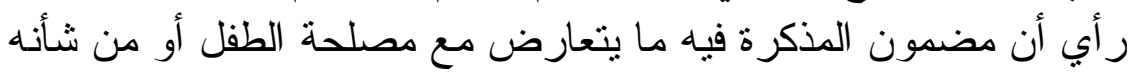
إثارة الضغينة مع أحد الخصوم. 
